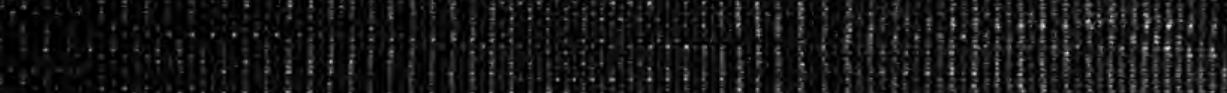

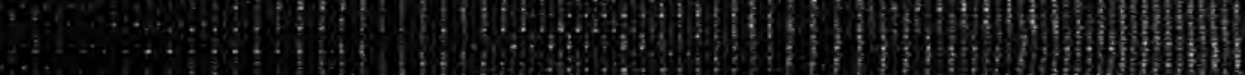

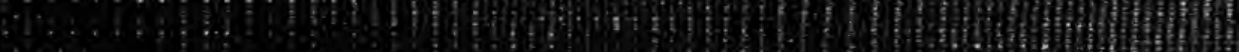

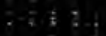
20.

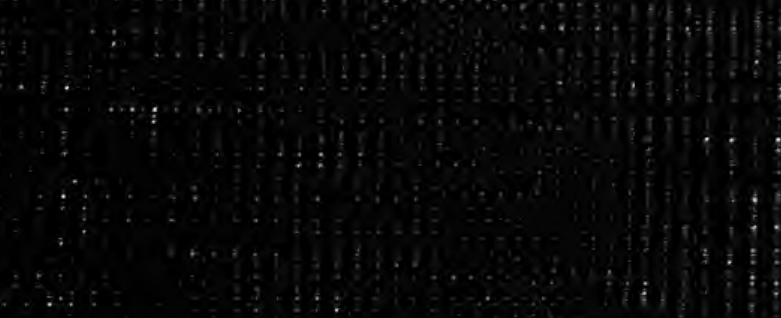

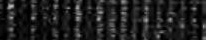

Sition Q
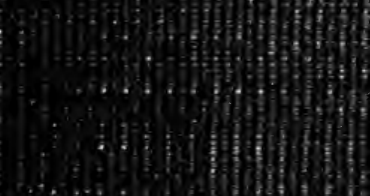

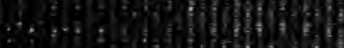
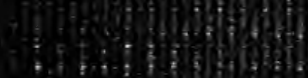

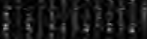

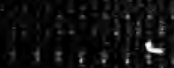

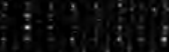
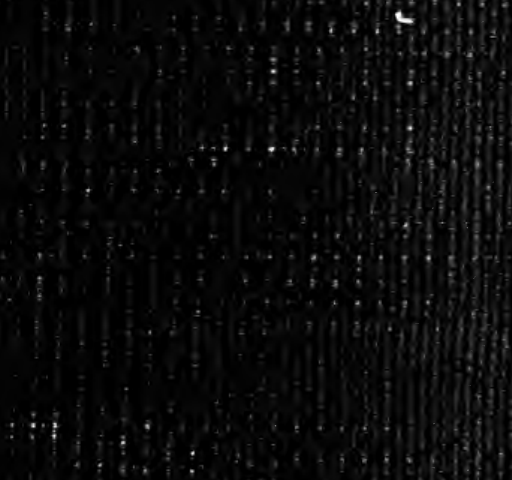

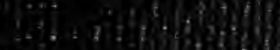

$\therefore$

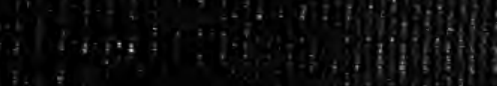

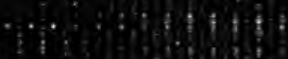

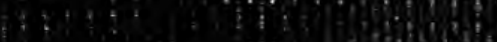

+209 in:

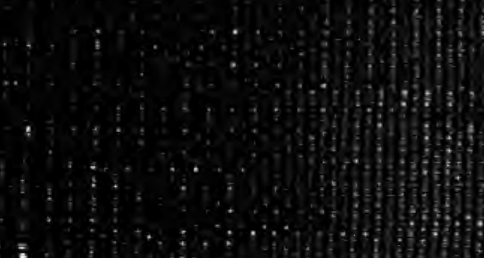

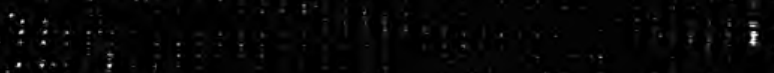



Y. 
NEWEST ENGLAND 
Dtber Boohs bp

Eenry Demare

8

Wralth against Commonwealth

A Strikg of Millionajegs Against Miners

Labor Copartaresship

A Country Without Strikes 
Digitized by the Internet Archive in 2007 with funding from Microsoft Corporation 


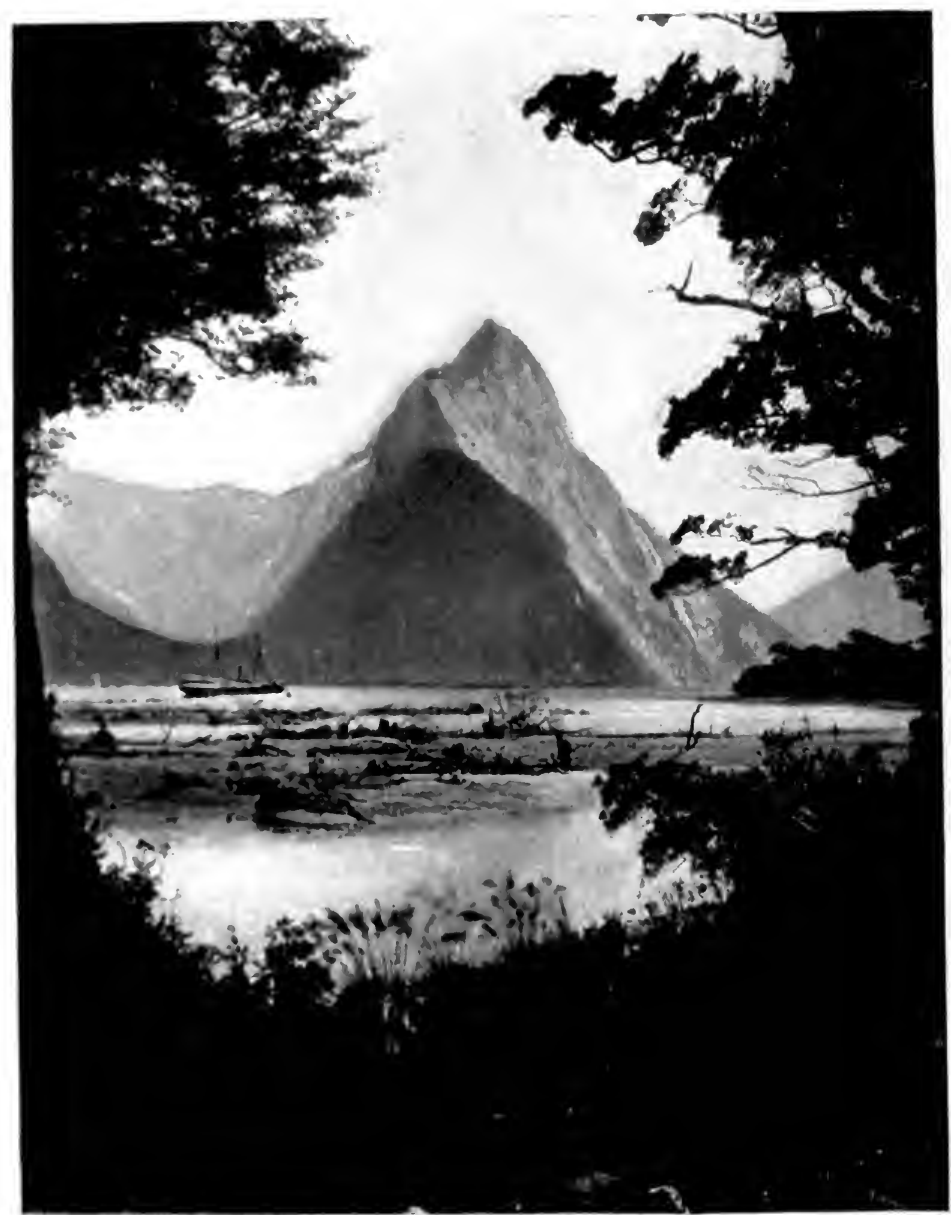

(Page 34.)

dilford Sound. 


\section{NEWEST ENGLAND}

NOTES OF A

DEMOCRATIC TRAVELLER

IN NEW ZEALAND, WITH SOME

AUSTRALIAN COMPARISONS

BY

HENRY DEMAREST LLOYD

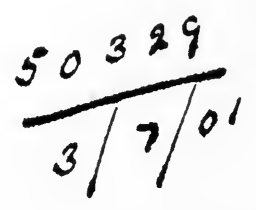

NEW YORK

DOUBLEDAY, PAGE \& CO.

1901 
Copyright, 1900, by Henry Demarest Lloyd. 


\section{CONTENTS}

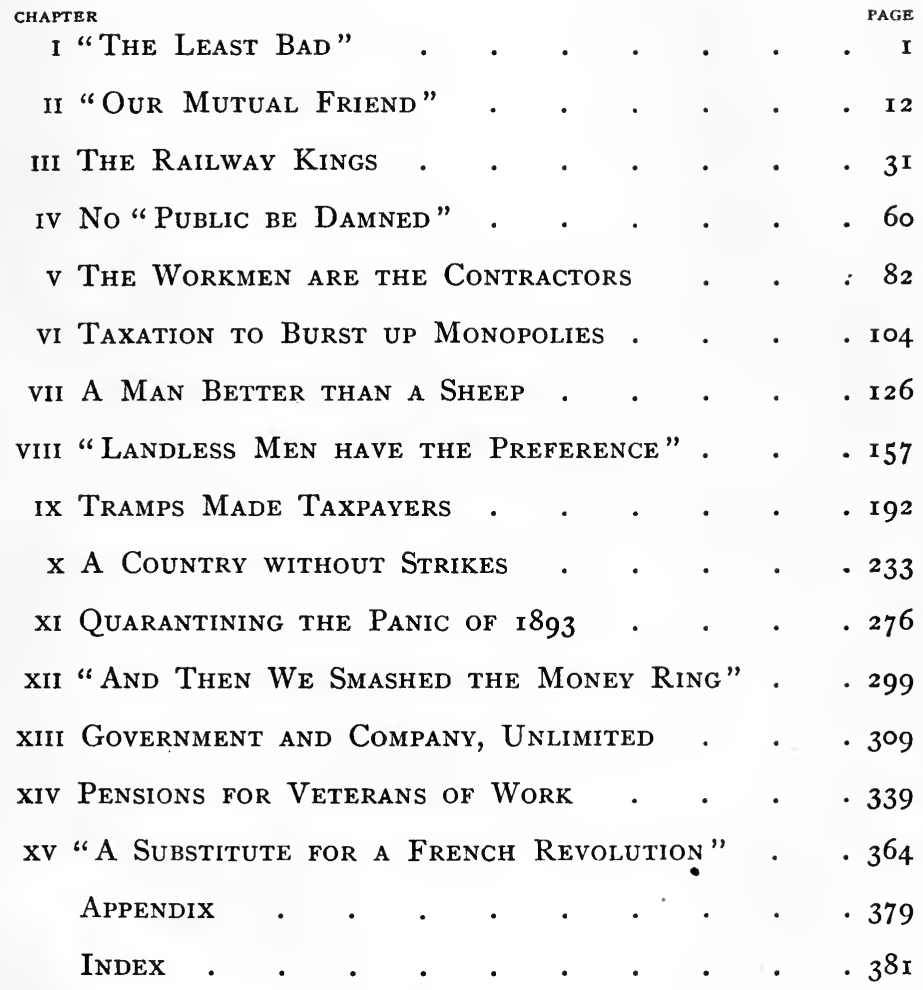





\section{LIST OF ILLUSTRATIONS}

MILFORd SOUNd . . . . . . . Frontispiece Mт. Cook · . • • . . . . Facing Page 34

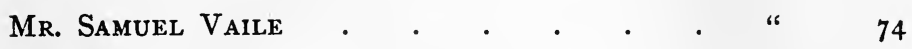

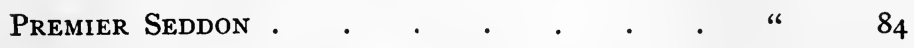

A Co-operative Group at Work • . . “ 492

Unemployed Building the Mahokine Viaduct “ 96

Cheviot - One Man Owned as Far as He Could See “ 158

Cheviot-After the People took it Back • “ 168

MONEy, LAND, Work, INSTRUCTION • . • " “ 190

A Home in a Village Settlement . . . " “ 192

Waste Labour applied to Waste Forest a " 200

FAMILIES ARE KEPT TOGETHER . . . . " 200

MT. Egmont overlooking Whangamomona • " 208

Tents are Ready for Them • . . . “ “ 214

The Hon. William Pember Reeves (Author of

the Compulsory Arbitration law) • • “ 258

White Labour in the Sugar Cane . . . " “ 3 ir

Tin for Houses on the RoAd to INDEPENDENCE “ 372

LAND FOR THE LANDLESS, WORK FOR THE WORKLESS “ 372 



\title{
NEWEST ENGLAND
}

\author{
g \\ CHAPTER I \\ "THE LEAST BAD"
}

I WENT to New Zealand to see what had been done for a higher social life, by the methods of politics, in the country in which those methods have been given the best trial. That that country is New Zealand will be admitted by all, by those who approve and those who disapprove. New Zealand democracy is the talk of the world to-day. It has made itself the policeman and partner of industry to an extent unknown elsewhere. It is the "experiment station" of advanced legislation. Reforms that others have been only talking about, New Zealand has done, and it has anticipated the others in some they had not even begun to talk about.

Co-operation-with its stores, factories, banks, and, now, farms, where the consumers and producers, the capitalists and the labourers, are the same people-is the "Farthest North" in the sphere of self-help. New Zealand democracy is the Farthest South in the sphere of politics, which must still be called "self-help," for in a democracy, in self-government, state-help is self-help.

This country with the newest institutions has the oldest land, Alfred Russel Wallace and colonial geologists tell us; but if the first to be made, it is the last to be used. When the Maoris reached it about five hundred years ago 
they found it almost wholly destitute of food plants or food animals-except a few unappetising, but, as the event proved, not indigestible aborigines. It was an unfurnished house; even the rat was imported, and by accident, in the canoes of the first Maoris. Cattle, game, cereals, vegetables, fruit, men and institutions have all had to be provided, and the process is still going on. The ship on which I went carried, besides the other American passengers, three hundred and fifty Kansas quail to the New Zealand Acclimatisation Society; and I arrived in time to see the first quarter's payment made to worn-out working men and women by the only people in Christendom who have been willing to tax every one of themselves for oldage pensions.

New Zealand lies about as far to the south of the equator as Japan to the north. It is, like Japan and like the mother country, a group of islands, and is not unlike Japan in the lie of the land, running in a long narrow strip about fifteen hundred miles north and south, and is like Japan in a beauty of scenery which even the oldest traveller finds it hard not to rave about.

It lies midway between the extremes of the tropics and the pole, and is cooled by the mountains and the sea, with plenty of rain and sunshine, and all that rain and sunshine bring. Australia is a sunburned continent, desert in the interior and almost without rivers, rimmed with a fertile coast-line, with droughts lasting for years, but the New Zealander begins to grumble about the "drought" if he goes a month without rain. The climate is a wine without headache; like that of Japan, the best, though not the most perfect, to be found anywhere. It has the variability that gives vigour, without the perpetual smile that makes Hawaii so depressing, if you outstay its first welcome. The soil is largely a wash from the mountains, and you hear 
nothing of the malaria which plays such mischief with the early settlers in the Mississippi Valley and in Africa.

Almost every New Zealander lives within sight of the mountains or the ocean, or both. Its landscapes show long ranges and solitary giants, tipped with Alpine glow; there are waterfalls everywhere, some of them among the finest in the world, luxuriant country-side, golden farms, lakes, geysers, volcanoes, forests with miles of pink, white, and red flowering trees in spring, and there are fiords of the sea threading their way around the feet of mountains crowned with glaciers and perpetual snow. The scenery is a synopsis of the best of Norway, Switzerland, Italy, and England, with occasional patches of Gehenna in the pumice country around the hot lakes.

New Zealand has the area, approximately, of Italy, but Italy has forty times its population of about 780,000, and 40,000 of these are Maoris. Australia is as large as the United States without Alaska, but has only a little more than one twentieth of our population, and only one ninetyfifth of that of Europe, which it equals in area, but in area only. We speak commonly of New Zealand and Australia as if they were in hail of each other, but New Zealand is half as far from Australia as America is from Europe, and they are stormy waters that guard those shores. He will need to be a bolder and more successful invader than Philip of Spain who proposes to land hostile troops on the coast of this Britain of the Pacific.

It is not so much the fashion as it used to be to interpret men and their institutions in the terms of their climate and soil, but if any people and any institutions are, and will be more and more affected by these things, they are those of Australasia. This is especially true of New Zealand. Its isolation protects it from tidal waves of heat, cold, immigration, fashion, speculation, or invasion. The 
people are likely to remain what they are-the most homogeneous Anglo-Saxon blend, the most harmonious constituency of our race there is anywhere-English predominant, Scotch next, Irish third. There is practically no other blood; the foreigners and Maoris are too few to colour the strain.

There is a soil of wonderful fertility in New Zealand, but it lies in patches, in valleys, and between mountains and the sea. The eyes were easily picked out by the first comers. Great stretches are fit only for sheep and cattle, and so only profitable when held in large blocks. This is just the environment for land monopoly, which soon took on an intense form, with consequences economic and political, which will need many of the following pages to describe. Immigration into New Zealand and Australia was hard for men, easy for money; and Anglo-Saxon people on such a soil, with Anglo-Saxon institutions, including the greatest, the government bond, could borrow all they could use. Hence there is here, on a very small population, a very large debt-larger than in any other country, even France. The climate of New Zealand has no extremes, and the people are most moderate in their temper and policies. The purpose one hears them most often avow is that they mean to have no millionaires or paupers - a political rendition of Agur's "neither poverty nor riches." Their temperate climate is a clemocratic climate. for the more opportunities there are, the more need there is for democracy, which is the organisation of opportunity for all.

New \%ealand is made up of two large islands and some smaller ones-like the mother country-and race and situation are at work here, as Emerson saw them in England, making every islander himself an island, and, as is always the way with islanders, these are growing to their home 
with heart-strings stronger than steel. Its policy of prosperity for all instead of excess for a few will, for many ages, prevent the appearance in New Zealand of any splendour to tempt the cupidity of enemies. It is too far from Australia for federation. No matter what improvements are made in ocean travel, it will always be five or six times as far from Europe to New Zealand as from Europe to America. Modern steamships and, alas! men-of-war are converting the Pacific into a mere Mediterranean, but a Mediterranean of a new civilisation, a sea to connect, not to divide, the awakening East and the advancing West; but New Zealand, unlike its mother country, is so much to one side of the world's great currents that it cannot become the clearing house of these movements of commerce and population, destined to be the greatest of the past or the future.

Australasia produces more wealth and spends more for every man, woman and child than any other country, and New Zealand is the most prosperous of the seven colonies of Australasia. New Zealand has practically every resource for the support of life and the creation of wealth. It is a white man's country, if there ever was one, and the people fit the country with much more than the European or the American average of energy, physique, intelligence, honesty and industry. A tree falls in the forest and in its roots is found a gold mine; a citizen digs a posthole and cuts into a vein of coal forty feet thick. The most precious metal of all, iron, is found in abundant deposits, one of them in the Taranaki sands of inexhaustible quantity, and so pure and rich that it has so far defied reduction. There is flax, and there can be cotton whenever the people choose to grow it. There are nowhere travelling rugs so soft and warm as those made out of New Zealand wool. Electric power beyond calculation is going 
to waste in a thousand and one waterfalls and rapids. This exceeding bounty and beauty of their own home pulls more strongly every day against the recall of the old home. All these physical circumstances make for "New Zealand for the New Zealanders," and New Zealanders for New Zealand. The "lengthening chain" that ties these people to old England may easily lengthen into invisibility.

The crow in New Zealand strikes as sweet a note as any heard in the woodland; the robin has no song and no red breast; the native hen is the greatest of rat killers; there is a caterpillar which blossoms. These and some other productions of nature have done for New Zealand what the kangaroo and the ornithorhynchus have done for Australia-given it the suggestion of oddity and the marvellous. Rabbits and sweet-briars, introduced for pleasure, spread like wildfire, and it is an attraction to be duly advertised in the sale of land that it has been cleared of sweet-briar and fenced against rabbits, and then later the rabbit becomes a profit instead of a pest, and is exported by millions to feed the English.

There is something in the air which makes ideas, too, run, and not among men alone. A kea parrot, hungry or curious, tastes of a sheep lying derelict on one of the great grazing plains, and forthwith the whole tribe, hitherto irreproachably vegetarian, turns carnivorous, and not carnivorous alone, but epicurean. The kea finds that the kidney is the choice morsel, and, better than that, it is most to its taste when eaten from the living animal. Within living memory, the Maoris, on the contrary, have changed from cannibals into citizens and members of Parliament, and their women have changed from squaws to voters. The wools and plains of Africa and America were found rich with game by the natives and new arrivals alike, but the New Zealand larder was empty when man came. The 
European in search of "somebody else's burden" to carry off has never encountered any other aborigines with the strength, bravery and intelligence of the Maoris. They won recognition which no other aborigine has received. As property owners, voters, members of Parliament and even ministers in the government their rights are unquestioned. The Maori fought the white man so well for his land because he had had to fight nature so hard for his life. The lack of food, animal and vegetable, in primitive New Zealand developed this Maori out of the inferior Polynesian, and has left deep marks and beneficent ones on the social institutions of the country.

There are earthquakes and volcanoes in New Zealand, and some of the conservatives there number with them the progressive land tax, the progressive income tax, the labour legislation and old-age pensions. The traveller sees in and out of museums many varieties of the wingless birds peculiar to New Zealand, and, if he is a democratic traveller, he will think that not the least interesting among them are the capitalists, who have not taken flight as it was predicted they would if arbitration were made compulsory and the great estates were "resumed" by the government and cut up into small farms.

The secret of the democratic efflorescence of Australasia is the same as that of the new vigour shown there by European plants and animals. The secret is the same as that of the long step ahead of the mother country taken by New England, with its Puritans and Pilgrims. The wonderful propagative power of democratic ideas in Australasia is a fact of the same order as the miraculous multiplication of the European sweet-briar and rabbits introduced there. The old ideas and institutions, given a new chance in a new country, gain a new vigour. It is their new world. Hopes and purposes which had fossilised in the old country 
live again. When the holdback of custom, laws, and old families is removed, there is a leap forward as from a leash. What Australasia has been doing is only what England and the older countries have been slowly attempting to do. Paradoxically, too, this renaissance of democracy in Australasia is not the fruit of colonisation by religious enthusiasts, or social reformers, or patriots choosing exile, but of colonisation by plain, every-day, matter-of-fact Englishmen, thinking only of making a better living.

The one new idea which the founders of New Zealand carried with them-and a very important one it was, and most interesting to Americans-was that which revolutionised the policy of England toward its colonies and gave them home rule. The political foundation of the present English colonial empire was laid by a man almost unknown to the general public, though a man of genius both in thought and action-Edward Gibbon Wakefield. Wakefield was the first Englishman to read and apply the lesson written for English statesmen between the lines of the American Revolution. He took the lead in the colonisation of New Zealand, and secured for it and the other colonies of England the rights which have kept Canada, Australia, and, so far, South Africa, for the home countrythe rights to have their own legislatures, to tax themselves, and to be free from all control, industrial or political, by the home government, except that a governor-general sent from England represents the Crown, mainly as a figurehead. He makes speeches at the opening of Parliament and gives state balls. The actual government is in the hands of a ministry on the English plan, responsible only to the colonial Parliament. The only real power of the governorgeneral is like that of the Crown, the right of veto, and that, like the Crown, he practically never uses.

The Australasian people are not different from people 
elsewhere; they pursue their self-interests as others do and have no more fondness for martyrdom than others have; but these English people found themselves in a place and in a time in which the English tendencies could run instead of crawl, and they ran. Of everything that has been done in Australasia, the germs were stored in the older countries-every one. In all the list of Australasian reforms there is nothing bizarre, nothing out of line with the evolution in progress, even in monarchical countries, but it was the good fortune of the Australasians, and of us who can see that they are experimenting for the rest of the world, that they could make the history we sigh for, without making the revolutions for fear of which we do nothing but sigh. The importance of the work they are doing cannot be overestimated. In Australasia the westward march of empire has reached around to the eastern point of beginning. Even the Maori is believed by the best students of the Polynesians to have originated in India, and so when the white man arrived in Maoriland, Aryan met Aryan. There waited the last piece of virgin soil on earth where the white race can spend its governing genius, unhampered by climate, slavery, monarchy, vested rights and vested ruts, immigration or the enervating seductions of power over subject races. As Englishmen admit that America, in its Revolution, saved English constitutional liberty, we can hope that the Australasians, in their extension and acceleration of reforms that are in the air everywhere, are saving the commonwealth of the whole world.

This Newest England is no Utopia, no paradise. That is self-evident from the fact that honest, industrious people could reach the age of sixty-five, after having been twentyfive years in New Zealand, and yet need an old-age pension. Both New Zealand and Australia are far behind England and the United States in the new municipal life, which is the 
most promising thing in our politics, though as yet little more than a promise. Trades-unionism is still weak from the effects of the catastrophe in which it was overwhelmed by the defeat of the strike of 1890 . When I was in New Zealand a representative body of workingmen would not order the names of their officers published for fear it would make them "marked men" in the eyes of their masters. The press and the people are anxiously discussing the decrease of the birth rate, which, the inquirer learns, is certainly in part due to an economic pressure which makes people afraid to have children. Just now New Zealand is in a boom and everybody can get work, but it was only a few years ago that the reports of the Secretary of Labour were as gloomy reading as those of any other country. The streets of the larger towns swarm at night with young men and women who, unfortunately, are not unemployed, though their hands are idle. When the traveller reads the police reports of the principal Australasian cities he feels as if he were at home in New York, London, or some other Sodom and Gomorrah.

There is a sheep ring and there is a coal ring in New Zealand-we would call them trusts-and there are indications of others, such as a timber ring and a combination against the sheep farmers among the great meat-freezing exporters. There is not one of the new institutions on trial to deal with land, labour, taxation, finance and government industry which is not lame somewhere, as any reporter who was not a rhapsodist must declare, but this experimenting has this superiority that, though lame, "it still moves," and moves faster there than elsewhere.

New Zealand has reached no final "social solutions," and no New Zealander, citizen or official, can be found who would pretend that it had. All that they claim is that they have tried to find solutions, and they believe that the fair- 
minded observer will declare that they are entitled to "report progress" to the rest of us. They certainly are experimental. They know it and are proud of it, but do not think that could be made a reproach against them by the political heirs of such experimenters as George Washington, Thomas Jefferson and Samuel Adams.

The tactful portrait painter would not say that the New Zealanders were the most civilised, the most happy, the most prosperous people in the world, but they certainly are the least uncivilised, the least unhappy, the least disinherited. Danton's political genius taught him to say of the laws and policies he proposed not that they were good, but that they were the "least bad." There are no absolutely good governments or peoples, but some are not so bad as others, and for New Zealand it may be claimed that its government and people are "the least bad" this side of Mars. 
“OUR MUTUAL FRIEND"

THE company that insures the largest number of people in New Zealand is the people itself. The trustee who executes the greatest number of wills, holds the heaviest amount of property and has the best clientage is the people. Here is an insurance company whose policies can never become worthless, and in which the provision men make for their wives and children is safe from panic or pestilence without or rascality within. Any one who wants insurance for the benefit of his family, which will be backed up by the "good faith and resources" of all the people, has only to step to the nearest of the many agencies of the Insurance Department of the government, or, easier yet, to receive a visit from one of its numerous canvassers, kept busy by the state in going about among the citizens, pushing the sale of this mutual company's policies as industriously as the canvassers of the great private companies.

The old joke of the young man who, when informed by his father that he had been made by his will his heir and that Brown had been appointed trustee, begged that Brown might be made the heir and the son be given the better job of trusteeship, would lose much of its point in New Zealand, where there is a Public Trustee. Here is a trustee who never dies, never mistakes the money of his trust as his own, never runs off, whose wards never have to accept explanations instead of the money due, and the bur- 
den of whose mistakes, if he makes any, falls on the whole people and not on his individual wards. It is no wonder that the people in New Zealand hold more insurance in proportion than any other people in the world, nor that the insurance done by the government is equal in round numbers to that of all the private companies combined, though these in the past have done their best to drive the state from the field. Nor is it any wonder that the Public Trustee, the only government trustee in the world, should have almost a monopoly of the business in his sphere.

New Zealand owes these novelties, the Public Trustee and insurance by the state, to Sir Julius Vogel, to whose genius it is also indebted for the initiation of the great public works and assisted-immigration scheme of 1870 , by which the first important stroke in the material development of New Zealand was made. An incoming stream of English immigrants and railway material-blood and ironwas set flowing by this public-works plan of Sir Julius Vogel's across the ocean against an outgoing stream of ten million pounds of New Zealand bonds sent to London. There are many who attribute the ills which later befell New Zealand to this gigantic creation of financial indebtedness, bringing with it the inspiration and the material for delirious speculation in land, credits, etc., but it is only fair to Sir Julius Vogel to remember that he foresaw all this and tried to prevent it.

It was part of his plan that the state should get the benefit of the increase in the value of the land caused by this new population and new railroad construction. He proposed that the government should reserve the public lands along the railroads for future sale, and that a betterment tax be laid on the private lands opened up. These measures would have given the people their share of the value their public works created. But this brilliant conception of eco- 
nomic statesmanship he was forced to abandon. The colony was short of money, long of land, and could not look far enough ahead to see what he saw.

The prescience with which Sir Julius Vogel looked into the future, and the success with which he administered the affairs of the public, are all the more interesting from the fact that in the management of his own affairs he was notoriously indifferent. He died in 1890 , in London, where he was supported by a moderate pension. His assisted immigration was a great success. All over New Zealand one meets to-day sturdy men and women, with large families, living in industrious prosperity, who owe their new start in life to this scheme of Sir Julius Vogel's.

This novelty of insurance by the government was not the creature of a theoretical socialism. It was just like the government railroads-a practical answer of a practical people to a practical difficulty. The people wanted insurance, but they were so far from the world and so insignificant that private capital thought them hardly worth its notice. Since private capital would not undertake it, the people used their government to insure each other.

The Life Insurance Department was proposed in 1869 to the New Zealand Parliament and passed unanimously. The new venture was popular from the start, for the policies had behind them the guarantee of the state. The department began in 1870 with 463 persons insured, and in 1899 it had 37,848 policies. The total amount of insurance now outstanding is $\$ 46,525,7$ ro. There have been paid out $\$ 11,885,410$, and the department now has on hand $\$ 14,307,670$. It has received in premiums since its start $\$ 31,257,051$. Out of 75,692 policies held in New Zealand at the close of 1897 , the latest year for which these statistics are published, 36,174 were issued by the government, and of the total of $\$ 98,614,850$ of insurance represented 
by them the New Zealand government was responsible for $\$ 45,013,005$. The government does much the largest insurance of any agency in the country, and its transactions are practically half the total done in the colony.

Although New Zealand is the healthiest of all countries, its death-rate, according to the Commissioner of Life Insurance, being the lowest, its people are the most fully insured. The government insurance alone amounts to more than $\$ 60$ for every man, woman and child, or $\$ 33^{2}$ for every grown-up New Zealand man. Including the insurance carried by private companies there is an average of over $\$ 375$ for every New Zealand man, and of $\$ 30$ to $\$ 35$ on the average for every New Zealand woman over fifteen years of age. There could be no better test of the thrift of the community than the amount of life insurance its citizens carry for the protection of their women and children, and there could be no better proof than this New Zealand thrift that the self-reliance of the people has not been weakened by their great extension of government functions in aid of industry. This highly organised form of "self-help" has, as might be expected, increased and not lessened the self-reliance and thrift of the whole people.

The government manages its insurance business on the same lines as the private companies. It employs paid canvassers, has handsome and attractive offices, and issues prospectuses in language skilfully couched to invite the confidence and business of the public. The fact that the state is behind every policy has been, of course, one great element in its success. Another is the wisdom which has freed its policies from all oppressive conditions. They are, one of the latest prospectuses says, "practically free from conditions of any kind except the payment of premiums as they fall due." The single exception, framed in the interest of public policy, is that the commissioner may de- 
clare a policy void if the insured commits suicide within six months after taking out his insurance. "All policies are world-wide from the date of issue." The insured may "go where they please and do what they like, and if death occurs in Central Africa, at the North Pole, or on the battle-field, the policy money with accrued bonuses will be promptly paid to the relatives."

The Insurance Department pays taxes like any other insurance concern, and its profits do not go to the Treasury, but to the insured. It is purely a mutual, self-supporting office. It pays for its own postage and telegrams. At first its telegrams were carried free, as the colony owns the wires; but when the proper principle was adopted of requiring each department to pay for what it received the telegraph business of the Insurance Department, which when it went "dead head" had been $\$ 10,000$ a year, ran down to $\$$ Iooo.

There have been five divisions of profits among the insured, and the total amount thereby returned to the policy holders has been $\$ 6,877,805$. There is a separate insurance under what is called the "Temperance Section" for total abstainers. Any one who does not wish to be "mutually" insured with those who have the drink habit can be placed with the other non-drinkers in this section. This experiment began in 1882 . As soon as the temperance section was established the total abstainers among those already insured demanded to be transferred to it from the "general section." Backsliders are slid back from the temperance section to the general section. When this experiment has lasted longer it will afford material for some interesting comparisons of the comparative health and longevity of drinkers and abstainers. In the division of profits of 1890 the general and temperance bonuses were equal. In 1893 the temperance bonuses were a little higher. In 
I 896 , however, this was reversed, and the general bonuses were better than those of the temperance section.

The millions of money held by the Insurance Department are an important element in the financial resources of the country. The department puts its funds into national and municipal securities and loans largely on real estate.

In the post-office at Cheviot, side by side with the oldage pension advertisements, was posted this placard issued by the Insurance Department:

Cheap Money in Sums of One Hundred Pounds to Ten Thousand Pounds.

The Government Life Insurance Department has large funds available for investment at exceptionally low rates of interest.

The Department loans on first mortgage of desirable freehold securities up to three fifths of their value.

Valuations and legal expenses are fixed by the Department and are kept as low as possible.

Intending borrowers should apply within for forms of application and for all particulars.

J. H. RichaRDSON,

Government Insurance Commissioner.

Wellington, September, $\mathbf{1 8} 96$.

The growth in the transactions of this department and the fact that the American companies, after trying competition with state insurance, withdrew and stayed out until 1900, tell the story of government success. The Insurance Department does not pay as large bonuses as some of the private companies, but on the other hand it does not charge as large premiums. I took pains in different towns of the colony to inquire of its competitors as to its methods and 
their results. The testimony was unanimous and generous that the department was well managed and that the democracy had had the good sense to put and keep experts at the head. Some of the private companies claimed that though their premiums were larger their bonuses were enough larger to make the difference more than good, because, having greater discretion in their investments, they could earn a better rate of interest.

It was interesting to find that there was an agreement between the various companies, including the department. not to "run each other down." One of the managers of a very important Australian company, when asked what could be said of the shortcomings of the Life Insurance Department, replied that there might be some political pressure to get "billets" or places in the department, but not much. The average man, he admitted, was more likely to insure with the government than with private companies, because, not having the time or knowledge necessary to make an independent investigation, he preferred the policy which had the guarantee of the people behind it:

This year, in answer to petitions from trades-unions, Parliament has added accident insurance to the business, and put a stop to the abuses of private insurance of employés by employers, who were making forced deductions from wages. The department has long had fire-insurance business in contemplation, but so far nothing has been done. When life insurance was undertaken there were no powerful vested interests to oppose the venture, such as will now do all they can to keep the government out of competition with them in fire risks.

If compulsory arbitration is, as I think, the most important addition which New Zealand has made to the art of society, its Public Trustee is the most human aspect in which any people of our day presents itself to the persons 
who make it up. This creature of law, whom Sir Julius Vogel thought of only as an official depository of papers and a formal agent for the execution of the routine duties involved in trusts, has grown into a functionary with personality as well as officiality, touching the lives of large numbers of the people in hours of grief, disaster and helplessness, not only with the ready and ample resources of the state, but with the discretion and tenderness of a wise friend. If Abou ben Adhem had his choice of New Zealand offices, this would be the one which he would take in preference to all others for his chances of doing good and giving happiness.

The institution was created in 1872 . People making their wills may leave their property in the hands of the Public Trustee; the property of those dying without will is given to him if those interested do not appear, and frequently even they ask him to do the work for them. If the courts have to find a trustee, the best of all possible trustees is ready at hand.

A man named by some relative in his will as executor of an estate too distant or for some other reason inconvenient, hands over the trust to the Public Trustee. The conductor of a great business dies with no relative or partner near. For the enterprise to stop means ruin and the loss of everything to his heirs and yet they may be at the other ends of the earth. The Public Trustee steps in and keeps everything going until the rightful successors are found and can relieve him. To this agent of the people, cities or individuals desiring to create a public trust can betake themselves. A widow left property in different parts of the colony, which she does not feel capable of managing, puts herself in his hands and knows that she is safe; or, she wishes to go "home" to the old country, to see her friends and family, and wants to be sure that when she returns 
her agent and her property will both be where she left them.

When a man has undertaken to manage the property of some dead friend, but becomes disqualified by illness, or desires to leave the country, he has but to ask the Public Trustee to take his place. When one has an estate of his own too far away for him to manage, the same official will manage it for him for a very moderate fee. If a philanthropist plans to create a long-continuing trust to carry some generous intention down to posterity, he need spend no anxiety on the problem of how to constitute his board of trustees. The Public Trustee is there and always will be there, and behind the Public Trustee is the public itself, responsible for his administration to the last dollar. If a man or woman goes crazy - and that happens even in paradisiacal New Zealand-“'Our Mutual Friend” assumes charge of the property and conserves it for the benefit of the lunatic and his next of kin.

Wills, deeds, trusts, or any other papers intended to place trusts in the hands of the Public Trustee are examined by him in advance, free of charge, so that there may be no chance of misunderstanding or failure. These charges for the different services are all fixed by a published scale and are very moderate, being intentionally made only large enough to cover the actual expenses of the office.

The fame of the Public Trustee has spread, and people so far away as England are placing property in his hands. The number of estates in the department has grown from 1678 in 1890 to 2491 in 1899 , and the value from $\$ 6,200$,485 to $\$ 10,551,581$.

You do not have to wait for the Public Trustee to find a particular investment for the property you place in his hands. The law provicles that the department shall at once begin to pay, like a savings bank, a specific rate of interest 
on your funds, just as if they were a deposit. Its present rate is four per cent. up to \$15,000, and three and one half per cent. above that. This is paid quarterly and is compounded until six years have passed, after which simple interest is paid. You do business with the Public Trustee under these very attractive conditions-the state guarantees you against loss from the investment of your money in bad or insufficient securities, provided you have left him to his own discretion; it guarantees you against loss from delay in finding an investment for your money; it guarantees you a regular rate of interest, payable at regular intervals, free of all charges.

But the feature which most aroused my interest was the large discretion which the Public Trustee had in the discharge of his duties and the kindliness which this has enabled him to display, like a good fate, in the destinies entrusted to his care. Private trustees are tied down to the strictest fulfilment of the letter of their trust, no matter how narrow or mistaken; but the law allows the Public Trustee to use his judgment and even his heart to make good deficiencies or omissions in the instruments under which he acts, and to do what the creator of the trust must be supposed to have intended or what he ought to have intended to have done.

I passed few hours in New Zealand with deeper interest than those I spent with Mr. John C. Martin, then Public Trustee, since raised to the Supreme Court and made Presiding Justice of the Court of Arbitration, familiarising myself with the methods of his office and hearing some of the stories of his administration of the welfare of those who had become wards of the nation under him.

The Public Trustee is a Corporation Sole; hence once he has been appointed trustee of an estate the trusteeship never becomes vacant, and it is immaterial whether the individual 
for the time being holding the office disappears, resigns or dies, the corporation continues and, as a consequence. no expense is ever incurred by estates in appointing new trustees.

In connection with the Public Trustee there is a Government Board. This consists of the Colonial Treasurer, the Native Minister, the Solicitor-General, the Government Insurance Commissioner, the Commissioner of Taxes, the Surveyor-General, and the Public Trustee. The officials forming this board have been carefully selected by the Legislature. As the colony is responsible for the actions of the Public Trustee it is right that Ministers of the Crown should have the power to express their opinions as to the current business of the office, and two ministers are therefore on the board. Their being there does not give a power to the government of the day to control the affairs of the office, because the ministers do not form a majority of the board. Ministers, recognising that confidence in the office might be shaken were it thought they were taking part in its affairs, never attend the board meetings. The other members of the board are selected on account of their large experience and intimate acquaintance with the people, the affairs of the colony, the different districts, the values of land, etc., which they acquire through being the heads of their respective departments.

In the interests of the colony a further check is that the Colonial Treasurer and any officer of the Treasury authorised by him has access to all books, accounts, documents and papers in the Public Trust Office, and that the Public Trustee shall at all times furnish to the Colonial Treasurer all such information as the latter requires. Then, too, the Auditor-General has the same powers in connection with this bureau as he has in respect of any department of the Civil Service. 
The office of the Public Trustee is at Wellington, and there are agencies in all the large and small towns in the colony. The total number of these is thirty-three. In addition, arrangements have been made with the post-office by which the Public Trustee is enabled to receive money from any person at any money-order office in the colony, or pay it to them, thus saving clients the cost of exchange and remittance.

Wills are occasionally framed in such a manner that, owing either to the testator being ignorant of his position at the time the will was made or to circumstances having altered, it would be ruinous to carry out its literal terms. In such a case the trustee endeavours to do what is best, and if the majority of the beneficiaries wish a certain course adopted, every effort consistent with safety to the office is made to adopt that course, and even a certain amount of risk is taken so that the beneficiaries may derive the greatest good. It frequently happens that a testator will direct the sale of the whole of his estate, never thinking that personal articles, such as his ring, watch, and things of that sort, are of great value to his family but of little value to sell. In such cases the office invariably meets the wishes of the family in preserving these things for its members, and even if the estate be insolvent, so that it is absolutely necessary to sell everything, they are valued and offered privately to the family. Often, too, time is necessarily taken up in getting in claims and in realising the estate, and in such a case the office makes reasonable advances for the maintenance of the widow and infant children.

The Public Trustee is often appointed trustee of a fund created by the public for some charitable purpose. After a coal-mining accident many years ago, a public subscription was raised and the fund handed over to private trustees. Subsequently such trusts, by Act of Parliament, were placed 
in the Public Trust Office. For the relief of the widows and orphans of those killed in a serious mining calamity over $£_{30,000}$ was handed to the Public Trustee. Under this a weekly allowance is paid to each widow and a further allowance is paid to her for each child under a certain age. These moneys are remitted to wherever the widow or children may be and paid to them. In some cases it is to their advantage to receive, instead of the weekly allowance, a lump sum, and that sum is advanced and charged against the weekly allowance. In one case a widow owned a house which was mortgaged, and it was desirable that the mortgage be paid. This was done and charged against her allowance; in another instance a widow desired to purchase a cottage. She was given the money, and her allowance stopped. The cottage was bought in the name of the Public Trustee, and on the widow's death it will be sold and the proceeds returned to the fund.

Sometimes the colony makes a grant to the widow of some public servant who has died in harness, and the amount is handed to the Public Trustee for her benefit. Where the terms are general, such as "for the benefit of the children" of So-and-So, he does what; so far as he can see, is the best for them, possibly an allowance for board and clothing. Later on, as the children grow up and earn wages, this is stopped so as to have a fund in hand to provide for them should they be out of work, or to hand to them on their attaining their majority. In one instance a trust was created under which the Public Trustee maintains a number of cottages in which certain poor people are allowed to live free.

A man died leaving a will under which his property went to his father, mother, sister, and brother. Before his death he had been most anxious to assist his parents and sister and brother, and as the two latter were being well edu- 
cated and their education could not be continued without assistance from him, he determined to pay for a house which was being built by his father for the family, so that they could live rent free. Unfortunately, before the house was finished he died, and his will simply left the whole of his property to the family. "It was, I presume," the Public Trustee said, "my duty to have paid the father and mother their shares in cash and to have retained the shares of the sister and brother until they were twenty-one and then have handed the cash to them. But had I done so this would have been the result: The father could not have finished the house for want of means; the son, who is a particularly bright and promising lad, would have had to be taken away from the high school where his education was being paid for, and as he has passed through the ordinary standards at the state school it would have been useless for him to return to them, and he would have had at once to begin to earn his living, the superior education he has been getting for some time past being thrown away. It was obviously much more to the interest of the children that the house should be finished so that they had a home with the ordinary decencies and comforts of life, that they should be able to remain with their parents and have the benefit of parental control and home influence, and that the boy should be able to continue and complete his education. The father and mother being willing that their money should be expended in completing the house, the daughter, although legally an infant, as she was only twenty years of age, also being anxious that her money should be expended toward completing the house and the Office Act authorising me in Section 27 to apply moneys in my hands toward the 'maintenance, education and advancement of any person interested,' I took the risk of the daughter repudiating payment when she càme of age and handed her share to her 
father, and I also handed the son's share to him. This enabled the house to be completed and the rent to be saved, and the boy's education continues."

This public executor sometimes intervenes as a saving providence even in the case of property where a will has been made and other executors have been appointed who have been for some reason delayed in acting. A man carrying on a sheep ranch died and by his will had appointed an executor who was in Scotland. It was the busy season of the year. For the business of the station to stop would have resulted in an enormous loss. But no person could act pending the receipt of the necessary power of attorney from the executor'in Scotland. There was a section in the law passed to meet just such a case as this. The Public Trustee took charge of the station, carried its business on successfully, and when the executor came from Scotland there was little left for him to do.

By the law the Public Trustee is to take charge of estates left without will, unless the courts see some reason to appoint some other person, but as a matter of fact this official does not interfere in cases where there is a widow or children of the intestate desiring to wind up the estate themselves. The value of estates left without will and where there are no relatives to administer runs up often to many thousands of pounds. The Public Trustee has to administer for the well-to-do man who puts off making his will until it is too late, as well as for the unknown unfortunate who is found dead in the bush or on the diggings. Many a curious and pathetic tale could be woven from the histories of some of these estates. At the present time the office is administering the estate of a man who was murdered and also the estate of his murderer, who, just before he was to have been arrested, committed suicide.

"In all cases where a person has no relatives living with 
him, the most careful search is made of any letters or other documents which he may have either on his person or about his belongings to indicate whence he came or who his next of kin may be," Mr. Martin said, "and if we can find any indication on this point we write to the chief officer of police in the place indicated, or if the man be a foreigner then to the mayor or some other official in his native country, reporting the death and asking that inquiries may be made, and numerous instances happen where we are enabled in this way to discover who the next of kin are, and to hand to them their share of the estate.

"Sometimes many years elapse without any information being forthcoming, and then, possibly in some quite unforeseen way, a clew is found which, followed up, enables the proper persons to be paid. Quite recently we were able to hand over the property of a Frenchman whose estate came into the office in 1873 . No members of his family could be found until a shred of information came to us which resulted in our communicating with France, and we ultimately sent to that country the proceeds of the estate, which had grown from $\mathfrak{£}_{2 \mathrm{I}} 5 s$. $4 d$. to $£ 667$ I7s. 9d., and in another instance the shares of infants interested were retained for many years, and when they were finally handed over they had increased from $£_{33}$ Ios. to $\mathfrak{£}_{\text {I }} 37$ Iod."

In one case the Public Trustee was able to play, from the point of view of the state, a very self-sacrificing part and to save for helpless and innocent children rights to which they had no legal title, though their moral claim was indisputable. In this instance he acted as the representative of the government and yet divested the government of its rights for the benefit of these wards. The case was that of a man possessed of considerable property who had intended to make his' will in favour of his two children, but had failed to do so. He had frequently indicated to the son what 
properties he intended to leave him, and had told the daughter how he intended to provide for her. The son, a grown man, had worked as manager for the father, knowing that the property would ultimately become his, and had never drawn wages. The daughter kept house for the father and son without pay. When the father's death came, it was found he had left no will, and, what was worse, had not been married to the children's mother and his own parents had not been married. His children were illegitimate and unable to receive any portion of his estate. A harder case could scarcely be imagined. "Here, strictly speaking," said the Public Trustee, "I suppose I should have turned the children out on the world to commence life how and as they could. Despite all inquiries, no evidence was forthcoming to prove the marriage. Under these circumstances the estate goes to the Crown." The Public Trustee at once set himself to work to save the interests of these innocent children. He employed the son and daughter as caretakers and managers of the estate. He instructed them how to apply to the government for the surrender of the rights of the Crown in their favour, and in this application they were successful.

Lunatics' estates, unless there is some one more interested to be put in charge, are in the hands of the people's agent, and he acts on these general principles: First, the possibility of the lunatic's recovery is never lost sight of, and every effort is made to conserve his property so that it is available for him should he recover; subject to this, his wife and family have to be maintained during the period of his incapacity. Very large powers are conferred upon the Public Trustee, and where the lunatic's estate is not sufficient to pay for his maintenance in the public asylum and also to maintain those dependent upon him, the government is approached and invariably remits the payment for main- 
tenance so that the family may get the greatest good from the property. Often, too, whilst the income is not sufficient to pay for both the maintenance of the family and the patient, the capital, if the estate were realised, would more than pay for the maintenance, but would leave no income for the family. Arrangements are made with the government for postponement of payment of the maintenance money until, should the patient not recover, he dies, thus enabling the home to be kept together until the children have grown old enough to earn their own living. A case occurred where the wife of the patient left his land as she could not carry it on. It was of small selling value, but a rent could be derived from it which was more than it would, if turned into money, produce in interest. The wife had no home, but her husband owned a lot in a country town, and the Public Trustee built a cottage on it for her. The interest on its cost was far less than the rent of a suitable house would have been. The estate is kept intact, is made to produce the best available income, and the wife is provided with a home suitable to her condition and is made as happy as circumstances will permit.

Another patient owned orchards and fruit gardens, but owing to his failing mental health his affairs had drifted into a mess and the cultivation of farm and orchard had been neglected and his property was rapidly depreciating in value. The Public Trustee took hold, bought the necessary farm machinery, and a fair income is now being earned, the family are kept together in a good home and the capital value of the property has been enhanced.

A very important part of the duties of the Public Trustee is concerned with the management of native lands scattered throughout the colony. These lands the trustee rents wherever possible and pays the proceeds over to the natives. In his office we see the dusky Maoris coming in, men and 
women, to receive the money due them. One of the paradoxes of New Zealand life is that many white men live under Maori landlords.

There are many odds and ends in the business of the department. Any surplus from the sale of land for taxes is held by the Public Trustee awaiting the call of the owner. Land, the owner of which has disappeared, is ultimately sold by the Public Trustee and the money held until the proper owner appears.

"I mean to establish by-and-by," the Public Trustee said, "a law department. As it is, we do a great deal of law business. We invest a large part of our funds in loans on land and buildings. The other day a workingman sought a loan of one thousand dollars on his place; I accepted it, and asked him if he wanted me to draw up the papers for the transaction. He preferred that I should do it, and this is a common occurrence. We charged him thirty shillings for fees, registration, etc. A lawyer would have charged him five pounds for his services alone, besides the registration fee. We make wills and execute other instruments also for persons of small means. In this and other ways we are doing a great deal of conveyancing business for the people, and I mean to make it, as soon as the opportunity is ripe, a part of our regular duties to give advice and draw up papers for the people in all parts of the colony." A still wider scheme than this is being urged by some of the Progressives of New Zealand. They are urging the installation of government lawyers in every town and village' in the country to execute papers and to give the people legal advice at a minimum charge. 


\section{CHAPTER III}

\section{THE RAILWAY KINGS}

As I stood in the station of the government railway at Wellington one day, a train pulled up, two or three times the usual length, so full of children that they were bursting out of the doors and windows, among them not a few Maori boys and girls. They stormed the platform, filling the air with the music of their greetings and delight, and catching up those who were waiting for them, scattered through the streets of the city. It was an excursion of seven hundred school children from Masterton, come with their teachers to get a day's pleasure and instruction out of the metropolis.

A few days afterward a train left the same station as full of city children to be taken into the country.

These excursions are one of the specialties of the ownership of the highways by the people in New Zealand.

The ideal of the democracy is to run its roads for service, not for profit. "After we have earned enough to pay the expenses of operation and the interest on the money borrowed to build the railroads," the Minister for Railways says, "we reduce charges as rapidly as profits increase."

The Premier in a speech during the last campaign defined the railroad policy to be that any profit over the three per cent. needed to pay interest on its cost must be returned to the people in lower rates and better accommodations.

In these school excursions children under fifteen years of 
age are carried at rates so low that to go one hundred miles and back, a possible ride of two hundred miles, costs only fifty cents (2s.) or four miles for a cent.

Older children and the teachers pay one dollar for the same distance. These rates make it possible for the children from up country to come to the city, to see the harbor and ocean-going steamers and the stir of commerce. And town children are taken out to the foot of the mountains, to look at waterfalls and fern trees, and hear the tui bird ring its silver bell. The number of children and teachers and guardians who take these excursions amounts in one year to one seventh of the population.

Children of the primary grades are carried free on the railroads, but not farther than the next school. South Australia, New South Wales and Queensland also carry their school children free.

Scholars who want to go farther and those of the higher grades can have season tickets, second class, for any distance up to sixty miles, getting a possible one hundred and twenty miles a day of transportation for two dollars and a half to five dollars ( IOS. to 20s.), according to age, for three months. For the benefit of teachers who wish to attend Saturday training classes, a special ticket is issued, good for four months and for any distance, for seven dollars and a half; and there are special tickets also for boarding school children returning home for the holidays.

The working people are given the same rates for holiday trips as the young school children. The men and women in the factory can take their children, under fifteen years of age, to go for a summer day's outing at the same rate as if they were teachers with scholars. They can go, for instance, fifty miles out and back, or one hundred in all, for sixtyeight cents ( $2 s .9 d$.$) each for the grown ups and twenty-$ nine cents (Is. $2 d$.) for the little ones. 
A good beginning has been made in a service of workingmen's trains between the cities and the suburbs. Morning and evening trains are run out from the principal towns to the suburban limits at a fare of fifty cents a week. But these are open to all travellers, for there is strong opposition to the whole policy of class trains and class settlements for workingmen as undemocratic and tending toward the production of caste.

The parcel system is cheap and simple. A seven-pound parcel can be sent thirty miles for twelve cents $(6 d$.$) , and$ any distance by rail in the colony for twenty-five cents. Fourteen pounds go one hundred miles for twenty-five cents and any distance for fifty cents. It costs only seventyfive cents to send twenty-five pounds any distance. The rates on large parcels are intentionally made very high in comparison, in order that the heavy business may go by freight. The adoption of these parcel rates has been followed by a great increase in the traffic.

Newspaper publishers can send three pounds seventy-five miles for two cents ( $\mathrm{I} d$. .), and the highest rate for any distance is six cents. A bundle of one hundred and twelve pounds of newspapers goes any distance for fifty cents.

The libraries are recognised to be as much entitled to special consideration as schools, and books are taken to and fro between libraries and their subscribers at one quarter the parcel rates.

To help farmers to market their fruit and vegetables "if fresh and New Zealand grown and packed," fifty-six pounds will be taken any distance for twelve cents. A visitor returning to the city can bring with him any of the trophies of the garden of the "old home" as excess baggage at the same rates.

The railroads will bring the farmers lime to warm their soil free of charge; and a stallion, brood mare, ram, shep- 
herd dog, or any other domestic animal for breeding is carried free. To encourage the use of clean seeds shipments by farmers to seed-cleaning establishments are returned free of all railroad charges.

If a farmer, breeder, manufacturer or other exhibitor at an agricultural or animal show fails to sell the whole of his exhibit, it will be carried back free by the railroads. If he fails to sell any of it, it is not only carried back free, but one half of the forward charge is returned to him.

The New Zealand railroad tariff is literally a "protective tariff." Slate for house fittings if imported has to pay twelve dollars per ton, where slate of New Zealand manufacture pays only ten dollars. The protective freight rate against imported paper bags and in favour of the domestic article is almost double, and so on with other things.

Donations of food products for charitable institutions are carried at half rates.

Materials for making roads pay only half the regular rates, because "roads are feeders for the railroads." All these concessions in rates have been followed by an increase in the revenue.

As the state in New Zealand considers transportation a public business, it naturally has assumed charge of the paths and facilities for travellers, explorers and mountain climbers throughout a large part of the colony. On the way to Milford Sound, where mountains crowned with perpetual snow keep the ocean as calm in their embrace as an Italian lake, the traveller goes along a pathway opened and kept in order by the government; sleeps at night in its huts; travels in steamboats which are either owned or subsidised by it; refers to guicle books which are prepared and printed by it, and is in the hands of guides who are also its employés.

The "Hermitage" at Mt. Cook is the property of the state. and is not only owned but run by it, and run well. 


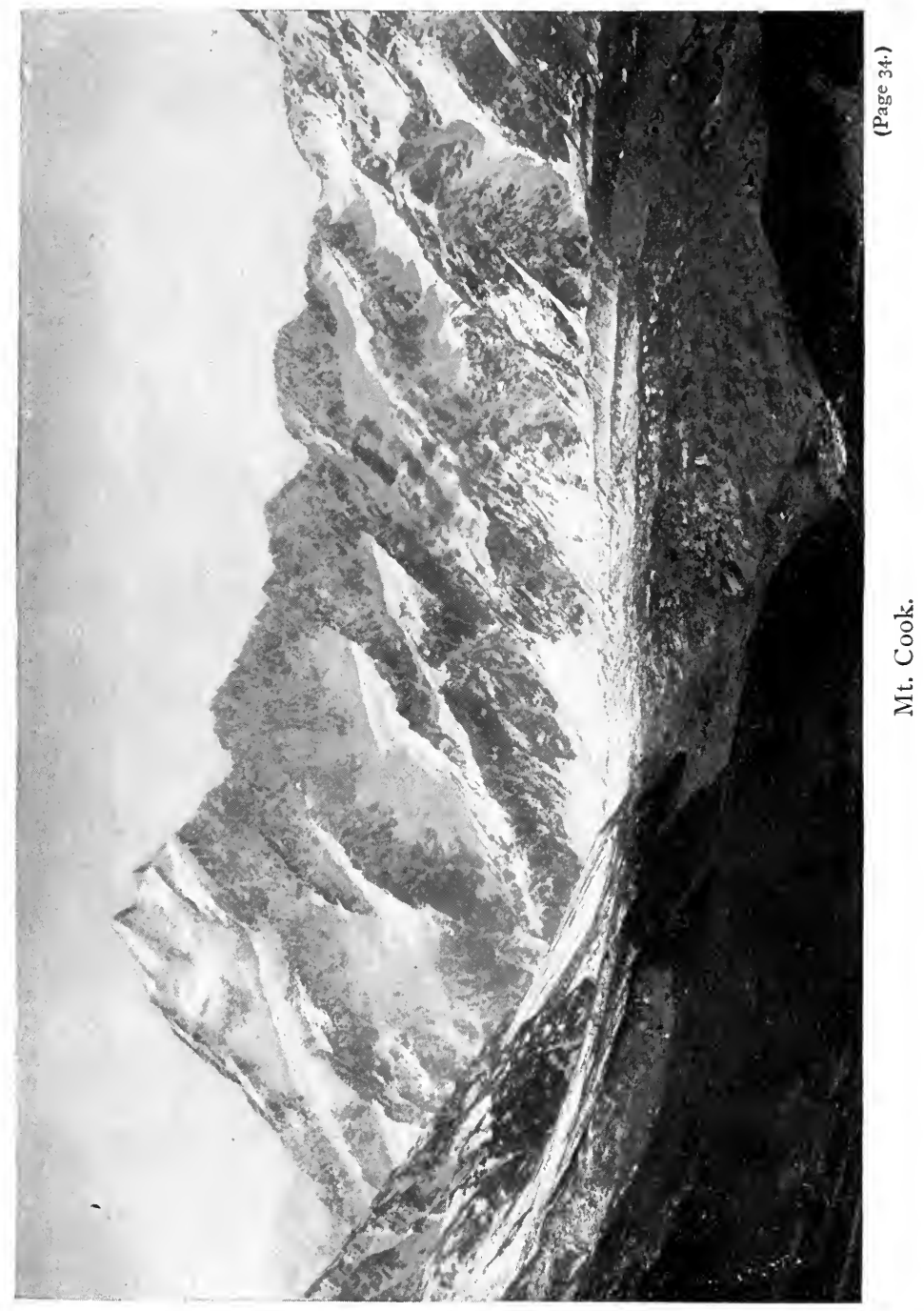



New Zealand railroad science knows nothing of the doctrine that a shipper because the largest is entitled to the lowest rate, to say nothing of the claim that the railroad manager has the right to give such favouring rates as to make the shipper he prefers the largest, even though he start as the smallest. Here, as in its land policy, the country deliberately and from reasoned conviction approves the opposite policy of favouring the small man.

Men who cannot ship by the ton are given a rate for four hundred pounds at a very small difference on the ton rate. The settler who brings down to the station his one bale of wool gets as low a rate as the company that sends off its thousands of bales.

In New South Wales where the merchant must ship six tons of any article to get the best rate the small men complained that this gave the advantage to their larger rivals. This was met by relaxing the requirement that the six tons must be of one article, and allowing the required amount to be made up of assorted lots. Russia does still better and takes a hundred-pound package from the small men at the same rate that it charges the great dealer who ships tons or train-loads.

Such a thing as a rebate or a discrimination in favour of one shipper against another is unknown in New Zealand. No would-be commercial conqueror can get the traffic manager of the New Zealand railroads to make him a rate which will drive his competitors out of business.

In discussing this matter with one of the railroad officials, I asked him what the unit of shipment was in coal. The rates for coal, he said, were made by the ton.

"Could a man," I asked him, "ship ten thousand tons and get a lower rate than the man who shipped one thousand tons?"

"No," he replied, "not if he shipped ten million tons." 
"There is no such thing known in the country as a reduction in rates for any quantity," the general manager said. And the officials of the private roads, of which there are one or two, were as emphatic that no such practice existed on the government roads.

I made inquiries, both of the railroad men and shippers, all through New Zealand, South Australia, New South Wales, Victoria and Queensland, and satisfied myself that such a thing as discrimination between shippers in rates, in cars or in other conditions, is unknown under the Australasian régime of public ownership.

The nearest approach to it I found in New South Wales. Here there are discriminations but with no touch of favouritism. The Commissioner of Railroads has power to make special rates for persons and places he thinks it desirable to foster, as in the case of new districts or enterprises operated under certain disadvantages, such as great distance from market.

To stimulate the foreign trade, the rate on wheat sent to Sydney for export, is much less than on wheat going there for home use.

Commissioner Oliver showed me instances of special rates, lower than those given the general trade, which he had conceded, as in the case of coal and iron mills which had an unusually long haul; but in no such cases, even though the rate is lower proportionately than that others enjoy, is the total charge made lower. The very distant enterprise may be relieved of paying the full tariff rate per mile, but its total payment is more than the concerns in competition which are nearer the market.

The railroad commissioners may use their discretion and give distant men a chance to compete on more equal terms, but they cannot go as far as railroad men have been known to do under the régime of private ownership and make the 
total charge the lowest to the men farthest away. "The company, especially if it be a large one," the official explained, "may get a smaller rate per mile, but its total charge will be greater so that the other companies cannot be frozen out."

Questioning the commissioners of the other colonies I found that the power exercised in New South Wales was not in use elsewhere. The South Australian Minister for Railways said, "We never make any discriminations in rates except to give free transportation to large shippers according to a published scale." He regarded the New South Wales practice as very dangerous.

The Queensland roads make no concessions to large shippers. The only special rates are on products to go abroad.

One of the chiefs of the Victorian service characterised the New South Wales policy of discrimination in vigorous terms as "deliberate injustice." "We would not do that," he said, "for any person or any corporation." Victoria makes special rates, open to alb shippers, for districts where it is necessary to meet competition by steamboats or by the railways of other colonies.

The New South Wales discriminations are not "secret" discriminations and there is no possibility of private favouritism. No special rates can be given unless the commissioner lays all the circumstances before his colleagues in the government and succeeds in securing the approval of the Governor-in-Council, corresponding to our President and cabinet. The rates must then be "gazetted," that is, published, and any person aggrieved is given seven days to be heard in protest.

Furthermore, in the quarterly reports of the Railway Department, every such concession must be itemised separately and explained. "There has never been a complaint 
or protest," the commissioner said, "nor a Parliamentary question about any discrimination in rates. No individual has ever come forward with a grievance."

In all the colonies railroad charges are regarded as taxation. The principle of "taxation according to ability to pay" becomes in railroad parlance the rule of "charging what the traffic will bear."

Rates favouring producers shipping for export are an acknowledged feature of the railroad management all through Australasia.

These concessions in the rates on produce for shipment abroad are made to meet foreign competition and to help accumulate in London the funds on which to draw to pay the interest on the government debt.

"We can afford," said one of the New Zealand railroad officials, "to help the men who are producers, if we make it up on the men who drink the tea and buy the dry-goods. So we make the merchandise pay and favour the producers."

"Political pressure" is the great bugbear of public ownership. Politicians "pulling" to get their henchmen jobs; local statesmen "log rolling" with each other to have roads built in their districts, which if the public interest were the standard would be built anywhere but there; "influence" that manipulates rates to the injury of men or sections with less "influence"; the "railway vote" thrown in solid mass by the corrupt administration to keep itself in power forever-these are the nightmares invoked to haunt the dreams the people are dreaming of days to come when they will own their own railroads. This seeking of office and appropriations and favours at the cost of all for the few, comes from a kind of human nature which is found in Australia as it is everywhere else. But over against it there is, in Australia, as everywhere else in this world, struggling "to free its hinder parts," another human nature which is seeking to control it. 
Where shall the new lines be built?

How shall the new employés be selected?

How shall promotion and conditions of employment be determined?

How shall rates be fixed?

These are the questions that private ownership seems to think are unanswerable posers for public ownership. But they are questions which, though they have proved troublesome in Australasia, have not been found unanswerable.

The building of new lines is left in New Zealand wholly to the initiative of Parliament, which acts on the initiative of the Ministry, which in its turn, acts on the initiative of the people.

The New Zealand newspapers are full of the reports of meetings held by the people in various districts urging the claims of this or of that new line on the attention of the minister of the day, and pledging their representatives in Parliament to work for it.

Auckland in the north has not yet been connected with Wellington, the capital, at the south; and at a large and enthusiastic meeting before the last election resolutions were passed that no candidate should be supported for Parliament who would not bind himself to the ardent promotion of this missing link.

Where new roads are to be built is settled in New Zealand by the democracy, by the democratic methods of agitation, petition, election and legislation.

In the Australian colonies, however, for this reliance on the methods of democracy, there has been substituted in the construction of new lines a complicated system of checks.

In South Australia no bill for the construction of a new railroad can be considered by Parliament until a sealed report has been laid on the Speaker's desk from the railroad department along with the bill. 
In Victoria, when a new railroad is proposed in Parliament, the project must be referred to a special Parliamentary committee, which has been created for that purpose. The severe financial depression which began in 1893, followed close upon a period of great apparent prosperity, during which large sums of borrowed money from London had been expended on the construction of new railroads. Land rapidly increased in price, and business of all kinds was prosperous. The passenger and freight revenue reached a high figure. With these bright prospects bills for the construction of hundreds of miles of new railroads, involving a further large expenditure were introduced into Parliament.

With the panic came the realisation that the apparent prosperity of the country was not stable, and Parliament sought a system by which the recurrence of such extravagant construction could be prevented. A standing committee was created of nine members, six from the lower house, three from the upper, to whom all bills must be referred.

Now the minister, after obtaining a report from the railroad commissioner as to the probable traffic and working expenditure of any proposed line, submits the project to Parliament and moves that it be referred to this committee. This is required to deal with all proposals separately, and a second proposal may not be referred to it until the first has been reported on and the report dealt with by the Legislative Assembly. The Assembly is required to declare that it is, or is not, expedient to carry out the work, or it may, if it pleases, refer back the report or a portion of it.

If it be declared inexpedient to proceed, no further proposal for the same work, or one in substance identical, is allowed to be submitted to the Assembly within twelve months unless the Governor-in-Council, by order of the committee, declares it to be in the public interest that the matter should be re-submitted to the Assembly. 
If the Assembly decides that it is expedient to proceed with the work, the minister is required to prepare and submit a bill authorising it. This may be amended as Parliament may think fit and when passed the authorisation of the new road is complete.

The Victorian commissioner who considers himself responsible, and is responsible, for the balance of revenues and expenses cannot admit merely public considerations into his judgment of proposed lines.

Parliament may decide, and quite properly, in view of the future good to the community, in favour of a line, but if that line will not pay immediately, the commissioner sees a great deficit threatening him and popular condemnation falling on his administration. It would be surprising if the commissioner under such circumstances always agreed with the standing committee, and there are sometimes sharp collisions between him and it.

In one case I learned of, this standing committee recommended a line which the commissioner unqualifiedly condemned. There were only three hundred settlers in the country which was to be given the new road and the commissioner told Parliament that it would be cheaper to buy them all up than to build where the cost could not possibly be repaid. Notwithstanding his protest the line was recommended by the committee. It was, however, not built, as the commissioner blocked it by declaring that if built as proposed he could not accept it and would not work it, as it was too cheap in its construction to be safe.

In New South Wales Parliament decides upon new lines, but the views of the Railway Commissioner must first be called for, as in South Australia and in Victoria.

When I was in Queensland, I found projects for new railways in Parliament involving a hundred million of dollars. As this was a great deal more than the value of all the roads 
already built, it was evident that Queensland was in need of some such restraining influence as that found for themselves by the other colonies in the measures already described, and a Parliamentary Standing Committee to sift and pass upon these schemes was under contemplation.

Rates are fixed in New Zealand by the Minister for Railways, and in the other colonies by the commissioners. Neither minister nor commissioners make any important changes without consultation with the Cabinet. In all the colonies, changes must be "gazetted" for the information of the public. Great power is given the commissioners. An advisory board of high grade railway officers has been created to assist the Chief Commissioner of Victoria, but he can as he chooses, regard or disregard their advice.

In all the colonies the ultimate power over rates, as over everything, is in Parliament, but there is this difference between the ministerial and commissioner systems. Under the former, the dissatisfaction of the people can reach the railroads immediately, for the ministry of the day can be overthrown by the loss of a majority. But under the other system, the commissioners are appointed for fixed terms, and can be removed only by the joint action of both houses of Parliament, through very complicated proceedings, which practically can be invoked only in cases of extreme misconduct.

Jolss involving the construction of new lines, necessarily take time, but the appointment of "my friend here" is so little a "favour" that it can be sprung on a commissioner or a minister at all times and by any one who has or thinks he has a "pull."

The democracy is fully aware of this evil of "patronage," and has been very thorough in clealing with it in New Zealand and all the other colonies.

In Victoria entrance to the railway service is by examin- 
ation, of which public notice must be given with all particulars necessary for the information of applicants. All candidates have to stand a physical as well as an educational test.

Among other things, the law requires that the notice state that any person who attempts to influence any member of the "Board of Selectors" shall be forever disqualified for employment in the railway service.

If more men pass the examination than there are places for, they meet and cast lots to determine who shall have employment; and the commissioner must appoint them in the order determined by this lot, and "in no other way."

The successful candidates enter the service at the bottom as probationers only. Vacancies occurring in the upper branches must be filled by promotion in regular order from the officers next in rank. No one can be passed over unless the head of his branch recommend in writing that it be done, and the individual thus slighted has the right to appeal to the commissioner.

"You must sometimes need an expert, a man with special qualifications, whom you could not secure by this method?"

"We provide for that. The commissioner in such a case makes a certificate that there is no one in the department qualified for the service in question, and is then given power by the Executive Council to appoint from the outside."

"Suppose you discover a genius among your men? How can you get him up to the higher place where you want him, in the face of this hard and fast provision that promotion shall be only in due order?"

"We are not often troubled by such a discovery; but if we are we have no trouble in putting the exceptional man where he should be. We simply put him there; but the head of his department must file a written statement that the men over whom he has been lifted are not fit for the work, and any official who feels himself wronged can appeal." 
In New South Wales the hearing of employés with grievances is given special importance by being made the only matter that requires the presence of all the commissioners. Men wishing to raise questions of promotion or change of wages or treatment, have a right to be heard by all three members of the board. It needs but two of the three commissioners to make an ordinary contract, but differences with the employés can be heard and decided only by the participation of them all.

In New South Wales the politicians and office-seekers have been barred out by the creation of a Civil Service board with unusual powers. This board makes periodical investigations of the conditions of public service and has discretion which it has freely used to abolish offices, to reduce salaries where extravagant, and to systematise admission and promotion.

This board practically controls the civil service subject to laws requiring examination and promotion. Appointments and promotions can be made only by its certificate. It has been made independent of immediate Parliamentary interference as the railroad commissioners are. A vote of both houses of Parliament is necessary for its removal, and its salaries are not matters of annual appropriation, but were appropriated to the necessary amount out of the general revenue at the time of the creation of the board.

By this institution in New South Wales the politicians have been completely routed, I was assured. "They never show their heads here," said one of the members of the board. "They have nothing to say. The politicians have absolutely no patronage, and the board has none."

This Civil Service board, the secretary of which is the eminent Australian statistician, T. A. Coghlan, has such authority that the engineers on public works cannot transfer a foreman from one job to another without its consent. 
The people of New Zealand, whether less sophisticated or more confident of their own democracy, have not had recourse to such a board. They regulate admission and promotion by law, but leave the practical work of the civil service to the good sense and virtue of the members of the government.

New Zealand demands an educational qualification of its railroad employés as it does of its factory hands. Every applicant for a place or "billet" on the railway must produce his school certificate. He cannot get a job as a labourer to wheel a barrow or to lay rails unless he has a certificate from the government schools, or one from some equivalent examination elsewhere, and the applicants for the higher positions must have higher certificates. These certificates take the place of the examination required in Victoria.

But examinations are required in New Zealand for promotion. No one can secure a place on the railway if the service already contains two members of his family.

The New Zealand force is thoroughly "classified," so as to insure that promotions shall be made only in order, according to priority and length of service, etc. But notwithstanding this the genius can be promoted if he can be found. The head of the department gives a certificate, as in Victoria, that the men over whom he is to be jumped are not able to do the work required. The intermediate men have a right to go to an Appeal Board, and in the election of this Appeal Board all the members of the railway force have a voice.

The condition of the railway men as to promotion, pay and treatment are much lightened in New Zealand by the existence of this Appeal Board, which is a sort of arbitration court for the railway men, and by the right of every officer and employé to take part in the election by which the board is constituted. 
The board has three members; one appointed by the government, one elected by the officers, and one elected by the men. Every railway man, no matter how obscure, has the right to a vote for a representative on this board and to go before it with his complaints against dismissal, reduction in rank or cut in pay, or any other question between himself and his department. He can also bring before this board any preference to other employés which he considers to involve injustice to himself.

The employés of the railroad do not have to remain silent under a sense of wrong, nor do they have to take their grievances before a superintendent independent of themselves. The member of the Board of Appeal who sits there as a direct representative of the employés, put there by their votes, sees that the evidence they want to give is received. And when their case is under consideration by the board he is there as spokesman for them.

In the year I899 there were only five cases before the board. Of these one was decided in favour of the men; four were dismissed.

"How can men with votes, in a public service ruled by votes, be kept 'in their place' and prevented from terrorising their superiors by political bullying?" Here is another of the hard questions private ownership puts to public ownership; but the Australasian colonies answer it, not easily, perhaps-nothing is easy in this wicked world-but with workable success.

At the time of the maritime strike of 1890 the New Zealand railroads were under "non-political commissioners." The railroad men joined the strike. When later they sought an interview with the commissioners, these refused to meet them, to the great delight of the business class and the corresponding displeasure of the workmen. The Union Steamship Company, next to the government the largest concern 
in transportation, pursued the same policy. "They saved the country," the president of the Industrial Association of Employers said.

This action of the commissioners in 1890 was one of the public grievances which led up to the overthrow of the commissioner system in New Zealand in the election of I893.

The railroad employés had the right to claim the benefit of the Compulsory Arbitration Law in its original form, but they have since lost this by an administrative change which was not meant, however, for that purpose. The Appeal Board has taken the place of the Arbitration Court.

The New Zealand government recognises the tradesunions of its railroad men; and there are besides these organisations-such as those of the drivers and firemen-two others, one of the "officers" and another of the "servants."

But the railway unions have not much power, for here, as all through Australasia, labour organisations are weak. The drivers, or engineers, as we call them, work nine hours a day. The mechanics in the government railroad shops work forty-eight hours per week. The number of apprentices is fixed to one in every four men.

The railroad men cannot strike. They may take their grievances first to their superior officer, then to the Appeal Board, and then, as a last resort, they can go to Parliament.

In his report for 1890 the Minister for Railways chronicles the "remarkable expansion of our railway business," and also that the government had voluntarily admitted its men to share in its prosperity by increasing the pay of all earning $6 s .6 d$. (\$1.62) to $\$ 1.75$ a day.

The remuneration of the engine drivers, firemen and some other classes had been also increased by an act of the legislature. This was a policy the opposite of that of the commissioners, who, when they needed to economise, reduced the wages of the men, but not the salaries of the officers. 
It may be cause and effect that the minister was able to congratulate the public on the extreme care shown by the staff in working the railroad. "Nothing but a deep interest in the work can account for the results achieved," he says.

The South Australian commissioner, like the New Zealand minister, recognises the trades-unions of his men. "We could not get around it," he said.

Naturally the heads of the railway service do not look with favour on the participation of their men in politics. In South Australia any railway employé who accepts a nomination must resign his place in the service. If he is defeated he does not get back. Formerly employés were not allowed to take any part in politics except to cast their vote, but that has been modified so as to permit them to do everything except to run for office while employés.

I was in the office of the Queensland commissioner when he was engaged in receiving a delegation of drivers, and his policy he said is "to meet the trades-union conditions as well as I can."

The fate of a movement of the tram men in Sydney-the national government owns all the street-car lines in New South Wales-just before I was there did not seem to indicate much consideration for the trades-union. The management had been presented with a round-robin signed by one hundred and sixty men complaining of liberties curtailed, pay reduced, grievances unredressed, and the like. The railroad chiefs, as they told me themselves, divided up among eight of their number the task of seeing these one hundred and sixty men individually, and they did not find one man who could-or at least would-specify a case to cover the statement. Five or six of the leaders were thereupon discharged and the thing ended. The men under the same leadership had refused to go into a provident fund proposed by the railroad commissioners. Afterward, to the 
number of five thousand, they petitioned to have the scheme reopened, but the commissioners refused.

The tram-car men in Sydney work fifty-five hours a week and their union is not recognised.

The railroad commissioners have spent eight thousand dollars on a club building and library for the men. The men in all parts of the colony pay $5 s$. (\$1.25) a year toward its maintenance.

The men are given a week's holiday for good conduct. The holidays they work, about a dozen in a year, are also credited to them. When they wish to go off, they have these days and a good conduct holiday allowance to their credit, and in this way can take two or three weeks with pay.

Every man who has been for a number of years in the employ of the New South Wales railroads and leaves through sickness, disability or old age, gets a grant besides his pay, which sometimes amounts to fifty pounds.

There is a pension in Victoria for the railroad men and an Appeal Board for men with grievances.

None of the Australasian governments make both ends meet in their railroads. None of them are able to pay out of the receipts of the railroads the full interest on the money borrowed to build them. The taxpayers have to go down into their pockets every year to make the deficit good.

In New Zealand, in 1898 , the roads earned three per cent. over everything but the interest charge; and if the railroad bonds were bearing only three per cent. interest, as would be the case were they refunded, the receipts would show a profit over interest, too, of .029. But the fact that some of the bonds carry four per cent. and more, prevents this showing of profit. The report of 1900 shows the earnings of 1899 to have increased to 3.8 per cent.

The amount earned on the capital cost of the railways 
for the other colonies for I898, was: in Victoria, 2.49 per cent.; Queensland, 2.93; South Australia, 2.69; Tasmania, I.07; New South Wales, 3.75; Western Australia, 4.62. As in New Zealand, this is not quite enough to meet the interest on the railway debt.

For the whole of Australasia, the railroads yielded 3.27 per cent. in 1898 on the cost of construction as represented by the bonded debt. It must be remembered that the roads are not run in the dividend spirit; not even under the system of commissioners. The commissioners run the roads on no more sordid a basis than to make ends meet. The head of the New South Wales department said to me, "We do not run the roads to make money, but for the convenience of the public and the good of the men."

The financial results just given are not discouraging, they are distinctly encouraging in view of the unfavourable conditions under which railroads are built and run in Australasia. The population is sparse, the distances long, and there is a lack of diversity in industry. That under such difficulties the service should be able to pay within a small fraction of one per cent. of all the expenses, including interest, proves that the people as owner and manager of railroads, has business ability of a high order.

The average New Zealand haul is thirty-five miles. In America the average is nearly five times this. At every important point in New Zealand, also, there is water competition. The government has not yet nationalised the steamship companies, but there is a strong movement in this direction favoured by prominent members of the present Ministry.

The statistics on which the claims of low rates and great reductions, year by year, on the American roads are made, are, as all students of the matter know, very misleading.

The average rate is low because large quantities of low- 
class freight, like soft coal, have of late years appeared in the statistics. But the local rates in America remain very high and have often been increased instead of lowered. With all the disadvantages enumerated above, the Australian roads, as some of the rates given above prove, do better for their public than the private roads of many other countries.

The New South Wales commissioners claim that their coal rate is lower than that of the United States, considering that their average haul is only seventeen miles and that for their charge of .o6d. ( 1.2 cents) a mile, a little over a cent a ton a mile, they deliver the coal on board the steamer at Newcastle. The coal rate in Queensland on the average is $.075 d$. ( $\mathrm{I} / 2$ cents) a ton per mile, and this includes delivery on board the vessels. New Zealand freight rates are of course high in comparison with ours. The country is difficult and young, the population scattered, and the railway system is not a connected whole, but is composed of a number of little railroads reaching out from the principal towns with the ends not yet tied together, involving a very high ratio of expenses to receipts.

Comparisons between results of public ownership in New Zealand and private management in other countries are absurd in face of this complete lack of any similarity in conditions. The only fair question is how do the roads of the state in New Zealand compare with their private roads? There are one or two private roads, and the discoveries of the traveller confirm the usual verdict of the New Zealanders that the roads run by the public are the better run and the private lines are inferior in rolling stock and other conditions and in their discipline.

The Wellington and Manawatu road, the principal private line of New Zealand, sometimes has sixty sheep cars on its best train ahead of the passenger cars. It runs fewer trains 
and gives the people fewer stations than the roads they operate. It takes four and one half hours to do eighty miles. It gives three suburban trains a day where the national line gives twelve. It does not charge higher freights, as it is bound by its charter not to do so.

New Zealand has a right to buy this line and the option will probably be exercised this year, as, if delayed, the owners have a right to exact a much heavier price. The stockholders see that the absorption of their road is inevitable, and they are anxious to have it come, for they already know what competition with the community is and realise that it could make their property of very little value.

The spirit of competition is strong upon a government in business as upon the individual in business. To Palmerston North, one hundred and forty miles from Wellington, by the state railway, the rates are made the same as those of the private Wellington and Manawatu road, whose route is only ninety miles long. But the people at the intermediate points, who have no access to a competitive carrier, are still charged the full local rates. I found the citizens of Oamaru full of bitter complaints against the railway management of the state. The city had gone heavily into debt to make a harbour and get the advantage of the water communication which reaches every place of importance in the whole colony. The moment the harbour was finished the department put down its railroad rates and the breakwater and the wharf stand idle, almost a dead loss.

Towns with water facilities get freights and fares at competitive rates. Those dependent upon the railroad alone receive no such concessions.

Oamaru's investment has borne fruit in the reduction of railroad charges, but from the point of view of the conservation of social energy it has been a loss to get this by wasting so much human force in useless construction. 
Another private line that promised to be important, the Midland, which was given a very valuable land-grant of six millions of acres, has become government property.

The colony had reserved the right to cancel the charter and take back the land in case of failure to comply with the conditions of the grant. In retaining this right it followed the example of the United States in its charters to the transcontinental and other land-grant roads. But here the imitation ceased. For when the Midland failed to complete its line as agreed, the New Zealand government, after showing all the consideration consistent with its duty to the public, forfeited the charter, resumed the land-grant, took possession of the road, and is now completing it with its own engineers and by the co-operative contract system, and is operating the finished portions as a state highway.

This forfeiture places a magnificent. estate in the hands of the Land Department for closer settlement.

There is a law in New Zealand under which private lines can be built, but it confers no power to take land for the right of way. This must be bought or given. The plans of any proposed railroad must also receive the approval of the government. There are laws for private lines in New South Wales also, and the colony has the right to resume possession of any such lines at a price to be agreed upon or fixed by arbitration.

There are no private lines in New South Wales for comparison of capitalistic with democratic operation. All the private lines are unimportant except that to the Broken Hill mines. This charges much more than the national lines, but all the conditions of the traffic are exceptional.

Some private lines have been chartered in Queensland in districts where the colony itself did not care to build. These enterprises are allowed, on account of the special circumstances, to charge half as much again as the public road. 
None of them are yet in operation and no comparison with the roads run by the people is possible. The Queenslanders, also, have reserved the right to buy up all these private lines if they desire to do so at an advance of ten per cent. on the cost of construction.

When English capitalists made Queensland an offer if given a land grant to build some very important links which would make a connected whole of what are now disjointed lines, the government approved the proposal; but the people to whom it was submitted by referendum voted it down. What they had learned of the results of land-grant railroad building in other countries was a warning they thought it well to heed.

Ownership by the people of the railroads in Australasia was a second thought. The first railroads were private enterprises; and under the direction of Gladstone, then Secretary of State for the Colonies, Australasia began, in New South Wales, the development of its system on English lines. But all the ventures failed miserably, and the colonies took advantage of the right they had reserved and took possession of them.

The inability of the private roads to get land grants on the American plan was one of the causes of their failure and of the state ownership that followed it. The English ministry then in charge of the colony refused to make any further concessions than that the roads might have public lands at the minimum price without having to buy them at auction. Besides this it would give them nothing. Had the question of favouring the railroads been at the discretion of a Parliament near the fountain of pressure, as Washington was near the corporations which wanted land grants, it is not likely that the pressure would have been any more successfully resisted in Australasia than it was with us.

But even with land grants it is not probable that private 
roads would have been successful. Their promoters, for one thing, would have found great difficulty in getting money. London capitalists are too sharp to look with much favour on the chances of profit in railroads built in a region so undeveloped, so erratic in climate and peopled so thinly. But railroad bonds issued by the state and backed up by the credit and resources of the people were another matter.

Private railroads practicable in America were impossible in Australia because there was not population enough nor business enough. Australia was too new. The government was the only agency that could overlay such a continent with a network of expensive thoroughfares.

The general intention when the railroads fell into the hands of the state was to lease them back as soon as possible to private companies; but the advantages and superiority of administration by it have led to the survival of the state as the fittest in the business of transportation, and the highways of Australasia have never become private property and it is safe to say never will.

With the ownership of the highways came as a matter of course state telegraphs and telephones as a part of the postal system. And with the post-office came the postal savings banks, and the many functions the post-office in Australasia performs for the public, as in New Zealand, in bringing old-age pensioners their money and in carrying the savings of the co-operative workmen on the public works to their families.

Like the railroads the telephone was at first a private venture in some of the colonies. Victoria, for instance, gave charters to capitalistic companies. This it did to its cost, as it had afterward to pay handsomely for its own gift when it took it back, and besides had to rebuild the lines poorly equipped by private enterprise. "The people demand the best of the government." South Australia, more 
prudently, refused the franchises asked for, and took up telephoning as a public business belonging to the post-office. The telegraph line that connects Australia with the rest of the world at Port Darwin traverses two thousand miles of South Australian desert from south to north, and at the stations in this desert the department raises its own sheep, cows and horses.

All that I heard confirmed the statement of one of the principal officials of the Wellington and Manawatu road, that the public opinion of New Zealand would not even consider such a proposal as the sale of the government roads to private capitalists. Several such suggestions had been made under the pretence of reducing the debt, but the people would not listen to them.

The people of New Zealand and Australia understand perfectly well their unique advantage in being the only countries in the world whose public debts stand for public works instead of public wars, and represent construction instead of destruction. The debts of Australasia have behind them, even allowing for the Maori war debt of New Zealand, a dollar of property for every dollar of debt. Increase of debt with them has been increase of assets.

These people understand, too, what it means to have the public highways operated by public policy instead of for private profit; and they know what it means to be free from the railroad millionaires, the highwaymen who levy toll under private ownership on every man's property, and possess in the rebate-making power a more than royal prerogative to create favourites of fortune.

The whole social and industrial fabric of Australia and New Zealand, its land, labour, agriculture and commerce, and consequently its financial adjustments at home and abroad, rests on the public ownership of the highways, and would be revolutionised by private exploitation for profit of 
the means of communication. Such a system would be unthinkable to the Australasian.

The only man in Australasia whom I found in favour of private ownership was in New Zealand, and he was an Irishman who had lived in America. He told me how at the primary election in Brooklyn his clique had beaten off the other faction of their party from the polls and prevented them from exercising their right to vote. "We had the captain of police," he said, "on our side. . He stood by and never said a word."

In the New Zealand workshops I saw government carpenters and machinists and other workmen building locomotives, dining-cars and ordinary freight and passenger coaches, and doing every variety of repairing. One of the chiefs of this department assured me the New Zealand locomotives were equal to anything in the world, even better than those of the United States.

"You make better locomotives than ours?" I queried. "Yes, sir, we do," he replied, "for one reason, because we do not make them for sale."

When I was there the department had just bought twelve thirty-eight ton American locomotives for $£_{1} 650$, delivered at Wellington, and ten sixty-ton engines for $£_{2000}$; the same locomotives bought in England cost $\mathfrak{E}_{3} \mathrm{I}_{5} \mathrm{O}$, and built in New Zealand just twice as much as the American article,

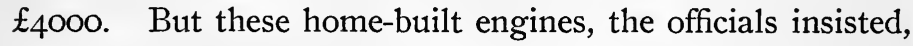
lasted longer and needed fewer repairs.

The department does not attempt to make all its own engines, as it has not the facilities in either machinery or in skilled men that would be necessary. It is against its policy to import for the purpose mechanics for whom it would not be able to provide uninterrupted work. The New Zealand policy with regard to immigration to-day is a very discriminating one. "Our work here is too intermittent for us to 
import mechanics to build locomotives. We would get a lot of men into the country whom we could not keep steadily employed and that would be bad for them and for us."

South Australia is now making some locomotives for itself. I found its workshops at Glanville doing quite an extensive business in the manufacturing of iron pipes and other findings. This enterprise has been in operation since December, 1894 .

The cost of the work done shows a very considerable reduction on the prices which were formerly paid to the contractors. A table given me by the Commissioner of Public Works shows that where the contract price, for instance, had been $\mathfrak{E}_{10} 2 s .4 d$. ( $\left.\$ 50\right)$ a ton, the shop price was $£ 8(\$ 40)$; and where the contract price was $£ 9$, the shop price was $\mathfrak{f}_{5} \mathrm{I} 6 s .3 d$.

Besides the manufacture of cast iron pipes, a great variety of work is being done in these shops for almost all the departments of the government service: railways, water-works, marine, post and telegraph, mining and stores generally. The convenience of having a general workshop, rough and ready as it is, has led to a saving of time and expense in the preparation of advertisements, drawings and specifications, and in the prompt execution of the various jobs. Victoria, New South Wales and Queensland have workshops but do only repair work.

When Sir Julius Vogel brought in his bill to borrow ten million pounds in 1870 for the construction of railroads and other public works, there were only forty-seven miles of railroad in New Zealand and the population was only 280,000 .

He had a comprehensive plan for the colony as a whole, but it went to pieces in face of local jealousies. To this day Auckland and Wellington, the two principal towns of 
the North Island, are not connected, and the railroads of the South Island joining its principal towns, Invercargill, Dunedin and Christchurch, have not yet been brought up to Cook Strait, across which lies Wellington, the political capital and the most important city in New Zealand. When it is urged that private ownership as shown in England and America has a better initiative than this, the New Zealander replies that all he would have gained by the private construction of the highways he would have lost afterward at the hands of the uncontrollable wealth and power he would have created. New Zealand sees how helpless the British and American public is in the hands of the owners of the highways and does not think the mechanical superiorities of capitalism worth as much as freedom.

The New Zealander thinks the inconveniences he suffers are part of the education of the democracy, teaching it to consider the common good instead of individual and local self-interest, and he thinks this lesson worth all it has cost and is still to cost. 


\section{CHAPTER IV}

\section{No "PUBLIC BE DAMNED"}

ONE thing incontestably results from the public ownership of New Zealand, and a very great thing it is-that the administration of public highways is the public's business. There is no Vanderbilt to say, "The public be damned"; there the people are the railway kings.

Every detail of policy regarding the extension, operation, and manning of the highways is public business, universally acknowledged to be such by the people, press, Parliament and ministry and business interests.

The New Zealand railways are in some respects almost primitive. They can be shown to be inferior to the roads of Europe and America in speed and comfort, though there are no such cheap excursions on the American roads as those given the schools and factories of New Zealand, and there is not on our "Sunset" or "Cannon-ball" limited trains any car equal to the "Bird-cage" car on the New Zealand express trains, composed of compartments with an outside corridor up and down which the passengers can walk under shelter, but with a full view of the scenery. This corridor is inclosed with a wire grating breast high, and hence the name "bird-cage."

The "scientific" traveller could fill a volume with the complaints which he could gather from the remonstrances of railway reform leagues, deputations to the Premier and Minister for Railways, from the debates in Parliament, and 
from individuals with private grievances. There is imperfection in everything human-even in private highways.

But whatever else they may have failed in, the democracy of New Zealand and Australia have not failed to make the management of their own highways their own affair. Railway policy on all its sides-as to freights, fares, new lines, questions between the employés and management-is continually before Parliament and the public. The Premier as he goes about a colony receives deputations here and there urging the alteration of this route, the construction of that new line, the reduction of these rates. Public meetings are held, representatives are instructed how to vote, resolutions are passed pledging the people to make this railway construction and that railway reform their "battle cry" and to refuse to vote for any candidate that will not support them. A deputation of the mayors of all the principal towns, of members of the largest chambers of commerce in the colony and of representatives in Parliament waits on the New Zealand Premier to press the claims of a route for the main trunk line in the North Island. The Premier promises that a full inquiry will be made, and that Parliament will be put in possession of all the facts needed for a proper decision.

When a new railroad is opened it is a festival not of speculators, but of the people. The first sod of the Gisborne-Karaka railroad was turned last February by the Minister for Railways, and other ministers were present. The Premier sent a telegram giving his pledge that the construction of the road should not be allowed to lag.

The wheat crop of 1899 was very large, especially in Canterbury, where it averaged twenty-five bushels to the acre, and the prices were very low. Forty-five hundred organised farmers of Canterbury sent a committee of three to wait on the minister, asking for a reduction in grain rates. 
These had remained stationary, while on other things the railway tariff had been lowered. The minister responded with the assurance that he had already considered the matter and intended to propose to the Cabinet that the rates on grain should be lowered and other concessions made to the farmers.

The Premier took the thing up and announced the next day in a speech in the political campaign he was making that reductions would be made amounting to an increase of nearly $\$ 1.75$ an acre in the income of a farmer who raised thirty-five bushels of wheat to the acre. The Premier also said that the total of the reductions which had been made to the people by his administration in the freight and passenger tariffs had relieved them to the extent of more than $\$ 1,250,000$ a year. This is just about the amount of the land tax. So that the same policy took off this sum from the people's transportation and put it on the large owners of land.

In meeting this delegation the Minister for Railways made a statement which will interest those readers who know of no other relations between the highwaymen and the public than those which they see-or do not see-where the railroads are private property.

"It is my custom," Minister Cadman said, "at the end of each financial year to draw up a list of reductions which I think could reasonably be made for the next financial year for the consideration of the Cabinet." The present financial year was drawing to a close, and he had drafted a list of products, including grain, manures of all kinds, cheese and butter, on which he would suggest to his colleagues that rates should be lowered.

He recalled the fact that he had stated three years ago, when he took over the railways, that as money was only earning three per cent. it was not requisite that the rail- 
ways should earn more, and any excess of earnings would be given to the producers. "This policy the government adheres to, for its producers are farther from the world's markets than those of any other country, and are entitled to every assistance."

A formidable organisation in Canterbury, New Zealand, the Canterbury Railway Reform League, bombarded the Minister for Railways with a carefully planned agitation for lowering rates for the city of Christchurch and its port, Lyttleton. They said "for many years past there has been a widespread feeling of dissatisfaction in this district with the policy adopted in the management of the railways. The objectionable features of the management have varied but little with the successive administrations of the last twenty years. The main principle that has been apparent throughout has been a determination to extract the largest possible amount of money from the pockets of the Canterbury taxpayers. Equitable rates and anything like a scientific and intelligent commercial policy have manifestly been subordinated to the exigencies of the treasury. There has been an unreasoning and almost uniform insistence upon high and vexatious charges. Instances are on record where it could be shown that it took years of demonstration to convince the official heads of the value even from a revenue standpoint of certain suggested alterations."

The league also charged the department with rates which were "obviously most arbitrary and unreasonable," and that they had "ignored the responsibilities which legitimately belong to common carriers." But the minister met all this with a determined defence of the methods of the department. $\mathrm{He}$ declined to make the changes requested. He pointed out that these would benefit mainly "a few wealthy traders" in the city of Canterbury, while the "country settlers" would get little or no advantage. 
Whether the league or the minister was most in the right is not the important point for us. That point here and in the other incidents we are noting is the right and opportunity to be heard and felt which the democratic operation of highways gives the public.

None of the travelling accommodations of New Zealand are what could be described by the American as luxurious, and those that have been provided for the second class are primitive in the extreme. Narrow, uncushioned seats, bare floors, draughty doors and windows make the cars cheerless and uncomfortable, though in New Zealand as elsewhere the majority of the travellers are second class. But the New Zealander has a better remedy for all this than sheeplike submission or mere grumbling, which does not reach the managers, and under private ownership would not move them if it did. His newspapers advertise the grievance. Parliament takes it up. Resolutions are introduced demanding the reform of this essentially undemocratic treatment of the majority. Public opinion finds the way to make itself felt by the railway officials, and serves them with notice that as rapidly as possible they must bring the accommodations of the second-class cars up to a better standard. Accordingly we find in the annual statement of the Minister for Railways for the next year that all new second-class carriages are to be provided with cushions and all the old ones are to be so furnished as rapidly as they come back to the repair shops.

As the time approaches within which the option of the government to purchase the Wellington and Manawatu railroad will expire, the chambers of commerce and other public bodies, including the local authorities of all the districts through which the line runs, meet in conference and urge the people of these districts to make the acquisition of the line a plank in their electoral platform, and measures 
are taken to enlist in this work all of the public bodies, chambers of commerce, and all the newspapers of New Zealand.

I was present when a delegation called to lay before the Minister for Public Works a resolution of an important conference demanding the completion of the North Island Trunk Railroad. That the construction of this railroad and the route which it should follow and the time within which it should be completed were public business and that the presentation of these resolutions and the request for this conference were the legitimate participation by the people in their own business was a matter of course.

The tariffs on the government roads are continual subjects of public discussion. The public of New Zealand never questions that it is the real rate-making power. It does not determine the details of the rate sheet, but it does determine the principles on which they shall be made.

Questions of administration and practical operation the New Zealanders delegate to heads of departments, but questions of general policy are delegated to no one. These are for the people.

Neither the public nor Parliament attempts to dictate to the management of the roads what the rates of fares or freights shall be in this or that case, but they are habitually and continually scrutinising them, and they think it is their business to exercise an effective and audible right of revision.

During the last campaign no topic was more steadily kept to the front by the Premier in his speeches than the reductions in rates that had been made and were to be made during his administration. In his report for 1899 , the Minister for Railways announced reductions of forty per cent. in the rates of farm products and twenty per cent. on butter and cheese. He showed that these concessions are equal to one seventh of one year's revenue. For the United States such 
a lowering of the railway charges would have relieved the people to the extent of $\$ 150,000,000$ a year.

One of the differences between private and public ownership appears to be that the latter never raises rates, a fact which the farmers of the Mississippi Valley and the consumers of the coal of Pennsylvania, who have recently seen the rates raised against them, would appreciate.

"Rates," said one of the managers of the New Zealand roads, "can be reduced. But it is an axiom of public ownership that they can never be advanced. The government once made too great a reduction on sheep. It lost so much revenue that it had to restore the old rates, whereupon the popular indignation overturned the ministry."

In the first speech made after the last election by the Honourable J. G. Ward, who has been given the post of Minister for Railways in place of Mr. Cadman, who retires on account of his health, after a very successful and popular administration, Mr. Ward announced a general lowering of railroad passenger fares as the first fruits of his administration. This announcement was received with cheers by the large audience-stockholders of the roads.

In all these matters-the routes of new lines, the treatment of the men, the fixing of rates-these incidents show how practically and really ownership by the government is public ownership, and how public ownership is for as well as by the people. The people know that they have something to say on all these points, and they say it. Their policy is only a compromise between the different desires and interests in different sections, each pulling its own way. It is, in other words, only human, but in this very conflict there is an educational value. There are mistakes, but even the mistakes are more profitable than a policy without mistakes if it had to be also a policy without democracy.

There are no air brakes even on the express trains in New 
Zealand-but there are no railroad wreckers in the boards of directors. There is no cord between the passenger cars and the conductor and engineer-but there is also no private wire between the president's office and the brokers in the stock exchange to the ruin of his stockholders. There were no dining-cars when I was there, though they have since been put on, but there were no Credit Mobilier nor construction rings feeding on the corporation. The rates are high, but what the traveller or the shipper pays the treasury gets. There are no rebates to favoured shippers, no discriminations in charges to shunt the business of merchants or manufacturers, who do not happen to be the pets of the traffic manager, into the hands of those who do have that lucky preference.

What Premier Seddon and the Minister for Railways, Mr. Cadman, meant when they said that the railways were not run for profit but for public service can be seen on every hand in the administration of New Zealand highways. In its relation to labour, production, exports, land settlement, relief of distress and the education and health of the people in city and country the commonwealth makes a use of its railways which would be impossible to private lines. Acting for the whole, it can make a profit for the whole even in losing money. Public ownership can therefore be a great economic success even when it makes no profit, while private ownership is often a success only by creating loss for the whole to make a profit for the few-as in the shut-down policy of the Pennsylvania coal roads.

The railroads are used in New Zealand at cost, or less, to redistribute the unemployed for whom the Labour Bureau has found places, and for the settlement of the people on the land as described elsewhere.

The key-note of the policy with which railroad building was inaugurated by Vogel was "public works and immi- 
gration." With the Liberals came in the new policy of "public works and the settlement of the land" now a controlling feature of the political economy of New Zealand. New Zealand, instead of sending people who want to settle on the land out into the wilderness, breaks up the great estates that have been formed along the lines of the railroads already built and settles the people there and increases its revenues from these roads, as well as from the new taxable values created.

Private builders of highways quite naturally appropriate by speculation the increase of value which plans known only to themselves will give. They thus interpose the barrier of a profit for themselves in the way of the settlement of the country.

Public ownership in New Zealand, equally intelligent in foreseeing the values its roads will make, appropriates this for the people and facilitates settlement.

Mr. Seddon, when Minister for Public Works, pointed out in one of his reports that the continuance of a certain railway construction then in hand meant that "every pound which the government spends upon the railway will give an increased value of twice that amount to the land through which the railway runs, which will be a benefit to a very few individuals." He announced therefore that it had been decided that it would be folly to go on until arrangements had been made with these owners, some of them natives, for such sale or lease of their land as would give the public the advantage of this "unearned increment."

In the chapter entitled "Government and Company, Unlimited" we will see how popular ownership of railroads stimulates the general prosperity by special rates and facilities to producers for export. In times of calamity the people can use the peoples' railroads for something better than "getting all the traffic will bear." After a destructive and 
very unusual snow storm in Otago a few years ago, in which vast numbers of sheep were lost, the railroad rates for stock were cut down. These "starvied-sheep rates," as they were called, permitted the farmers to restock their runs at a very low cost. "We expected," the minister said, "to lose heavily, but the increased traffic more than made up for the lower charges."

One department was thus made to come to the rescue of another. Here the railways saved not only the settlers but the land department, which would have incurred very severe losses in the rents of tenants brought to the verge of ruin.

All such changes of rates must be published, so that all localities and business interests may know what is being done and act accordingly.

But it is in its methods of construction that public ownership of the highways stands forth in its most attractive aspect. We see New Zealand building its roads without the sweating contractor. We see its men doing the work cooperatively. Coming from the towns as casuals they are deposited on the land in permanent settlements. They are changed as they work from tramps to taxpayers. The right and mercy of employment are given old men as well as young, delicate men as well as robust. We know that we could look through the whole world of private highways for only one instance like this, and look in vain.

The Minister for Railways calculates that the low rates at which he carries the school and factory excursions-four miles for a cent-makes his department lose heavily, but he is in a position where he can see and serve a larger public interest than making money, and he thinks it enough, as her states in his report, that "from an educational point of view very marked and beneficial results must follow." This is a creation of real wealth in the fullest sense in 
which Carlyle and Ruskin, and, in fact, all the true economists have urged it upon the people.

Much has been made by the critics of Australasian public ownership of the unsatisfactory results alleged of the administration of railroads directly as a department-what is styled the "political" system. These critics dilate on the fact that all the colonies were led in the years 1883 and following to substitute the system of administration by "non-political" commissioners. But these changes in policy are, at least, the best of evidence that can be asked that the democracy watch the management of the highways keenly and shrewdly, and are capable of a complete reversal of policy when it seems necessary.

The fact that after five years trial of management by commissioners the people of New Zealand went back to the former "political" method proves again the watchfulness and intelligence of the people and exhibits the democracy as a careful master of its own business. This return in policy was made only after much discussion in and out of Parliament, and only after a political campaign had been fought out on that issue resulting in an imperative mandate from the people to their representatives to make the change.

All the Australasian colonies except New Zealand retain the "commissioner system," and where it was the strongest I heard the bitterest complaints against the interference of politicians. One of the commissioners whose power is of the greatest, since he has the power to make new rates, to arrange methods of appointment to places, and must be consulted on new lines, confessed that his life was made a burden by the politicians. "The politicians are all on the job. The members of Parliament are simply commission agents for their constituents."

The people of New Zealand made the discontinuance of 
the system of railway management by commissioners or the "non-political" system an issue of the election of 1893 . They returned to Parliament men pledged to abolish the commissioners and put the highways again under the direct administration of a Minister for Railways and Parliament. The popular verdict was overwheiming.

It may appear to the American reader that an account of this struggle in New Zealand between the "commissioner" and "ministerial" methods cannot have much interest for him, since he is a citizen of a country which does not own its own roads. But there is no telling how soon this may become a practical question even in America.

The commissioner system was almost private ownership, and in its worst possible form, since the commissioners had the powers of private owners, but none of the responsibilities of owners who suffer loss for their mistakes. It was a commercial system. It made money for the treasury, and to that extent lightened the tax of the rich man. Management directly by the government, not for profit but for the best public service, disregards profits and does not, like the other policy, relieve the large taxpayer by paying the expenses of the state out of the earnings of the railroads. These earnings come out of the travel and traffic of the multitude, and to make a profit from them for the benefit of the treasury is to make the poor man pay for the government of which the rich man gets the greater advantage.

The commissioner system seeks to reduce taxes. The other seeks to lessen the expense of living for the people. It was by the sure intuitions of democracy that the people in New Zealand favoured the policy of direct Parliamentary control. By this policy, as population and business increase, the tariff cheapens and the public, by a lowering of the rates, is given the benefit of its own growth.

In all the other colonies the railroads, being under com- 
missioners who are railroad men pure and simple, are run just as railroad men would do it in other unregenerate parts of the world.

The "political" management of the New Zealand railroads can carry without charge lime for the farmer and timber for boxes for produce to be exported, because the public good will gain more from the prosperity resulting than it will lose in lime or timber freights. But the technical management by the commissioners in Victoria, who are railroad men first and last, when it is asked to carry coal below cost, refuses because it has to look out for the prosperity of the railroads and leaves the prosperity of the country to those whose special business that is.

One great value of the political method is that it gives a voice and chance to new ideas. It was not a railroad man who invented the sleeping-car, nor were Mr. Vaile, the inventor of the zone idea in New Zealand, nor the Minister in Hungary, who introduced an imperfect modification of it, railroad men.

The ministerial or Parliamentary system brings the railroad management within speaking distance of all the people for suggestions either as to abuses or improvements. The other is a "bureau" system, and is much less accessible and responsive, and by its very constitution cannot admit into its calculations a policy of reducing rates for the public good. The ministerial system serves the officials of the roads by giving them a voice in Parliament when attacked, and it serves the public by giving it a certainty of being able to attack and put the minister on the defensive.

The commissioner, or "non-political" system, as it is called, to give it the appearance of being free from the political abuses of patronage and the like, is non-political only in name. The commissioners under it know well they exist only at the pleasure of Parliament. 
Management by commissioners was inaugurated by the Conservatives-the party of property-in 1887 . It did not please the people of New Zealand. The commissioners were able to show in their annual reports a profit nearly equal to the amount of interest needed for the railroad debt, but it was evident that it was only apparent, and that both the roads and the employés were being starved to show this profit for the present glory of the commissioners. The true econony of the railroad system was being sacrificed.

Complaints of all kinds were rife. The commissioners were denounced as "monopolists," "irresponsible despots," and a "failure." They assumed the right to make contracts without calling for tenders, and ordered supplies abroad which could be furnished by New Zealand concerns. The public travelled with nervous apprehension over bridges which had to be propped up and where the screws could be seen to be a third rusted through. Rates were reduced, but by reducing wages. The labour charge was lowered by employing boys to an extent unknown before, and the New Zealanders do not like the spectacle of idle men and busy children. The treatment both of the shippers and the men was most arbitrary. When it was sought to economise the men were cut down, in the capitalistic spirit, but not the high-priced officials. Because of the high rates firewood went to waste in the forests and potatoes rotted in the fields, while the cities went cold and hungry during the years of depression. Some of the heads of the department were seen drinking champagne during business hours, and the public dissatisfaction was great. Produce was being hauled cheaper by waggon than by rail. The railway employés were in constant agitation, while the post-office men who were under the direct control of the government were tranquil. In the strike of 1890 the commissioners acted in co-operation with the great steamship monopoly and the 
associations of employers, and refused to grant the request of the railroad men for an interview to arrange terms of peace, and throughout their career refused to recognise the unions of the men. This their colleague, Minister Seddon, then of the Public Works Department, and soon to be Premier, declared to "amount to an interference with the liberty of the subject. So long as the railway commissioners maintain their present hostile attitude toward unionism, so long will their employés have ground for complaint."

The New Zealanders are very jealous democrats, and the fact that the commissioners were not under the people's immediate control had a great deal to do with their overthrow. The people are not afraid of the people in New Zealand. Changes were rung on every political platform that the fifteen million pounds invested in the railways were the property of the public, its most valuable property, and "the people demanded to be represented in the management of this property." It was said that the methods of the commissioners and the commissioner system itself were "an insult to the democracy." "The people of New Zealand," a member of Parliament said, "are the real stockholders, and Parliament should be the director."

When the people came to vote they voted by a large majority along these lines. Out of thirty-eight members of Parliament who had declared themselves against Parliamentary control, only ten were returned to power.

Premier Seddon introduced a bill of the most moderate character at the beginning of the new session, designed only to increase the voice of the state in the management of the roads and preparing for a gradual abolition of the commissioner system, but with the first day it became evident that when the debate closed the government would be in sole control. And so it was. Since 1894 New Zealand has run its railroads with the hand of the public on the throttle. 


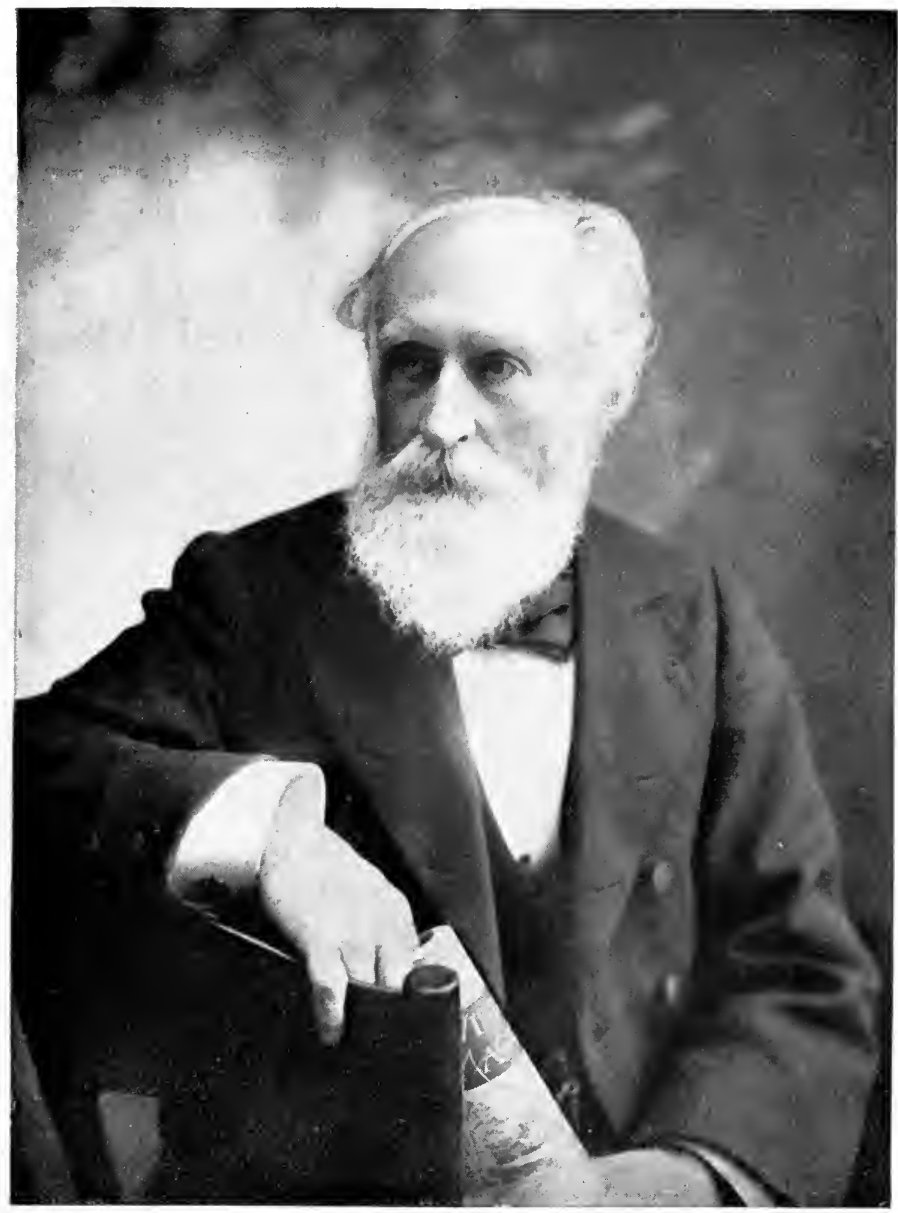

Mr. Samuel Vaile.

(Page 74.) 

The Conservatives who had put the railroads in charge of the commissioners in 1887 made it in the campaign of I 899 one of their grievances that the Liberals had returned to the "political administration of the railways."

The sweeping victory of the ministry in the election proved that the change had been to the satisfaction of the people. The statistics of the railways explain the popular satisfaction. Kates had been lowered, revenues increased.

The appeals of the men to the Appeal Board in case of grievances, of the shippers to the Minister for Railways for better export rates or lower freights in time of distress, the delegations from communities and chambers of commerce on construction of new lines or the purchase of private lines, the solicitous replies by the Minister for Railways to the manifestos of railway reform leagues, the large space in newspapers and Parliamentary debates occupied by railroad questions are all indications that the people have got the "representation" in the management of highways which they demanded, and that they use it. Libraries of criticism and of statistical comparisons to prove that freight rates are much higher and accommodations poorer than those of countries which enjoy the blessing of private ownership do not touch one point at least-and that is that the system suits the New Zealander better than any other, and seems to the people most concerned, those who have to use the railroads, to be for them better than the other, both as democracy and as political economy.

The participation of the Australasian people in the settlement of the problems of communication between themselves may perhaps also deserve the name of "modern improvement" almost as much as gilded buffets and electric lights and vestibuled cars.

A New Zealander, Mr. Samuel Vaile, of Auckland, claims the credit of first proposing the extension of the post-office 
principle to railway charges. This is an idea which has already borne great fruit in other countries, as in Hungary. The author of the discovery how best to use the railroads is likely to have a place among social inventors not below the Stephenson who taught us how to make them.

What Mr. Vaile saw among the poor of London-"no human pen," he says, "can adequately describe its depth of sorrow, shame and degradation"-started him on the search for the "cause and cure of civilisation," as Edward Carpenter has so well phrased it.

His first conclusion was that the prime cause of poverty is the inability of the people to make use of the land; and his second, that one great cause of this is the system, or no system, of railway management. By basing the rates on mileage and putting toll-gates at every mile the railways drive out of the country and crowd into the cities the people and their industries. These must shorten the distances between each other if they are to live. To remedy this $\mathrm{Mr}$. Vaile invented his scheme for railway zones. Instead of making the railway charge, as now, increase with the mileage, he proposes to make the rates dependent on the average cost of the service and the density of the population, and to vary them not by the miles, but by stages miles long, longest in the thinly peopled districts, shortest where the population is dense. The length of these stages is to be readjusted after every census. The advantage given to the smaller places and the sparsely populated and poorer regions under this method would disappear as they made the expected gains in population and wealth. The number of stages would then be increased and their length made less, so that these prospering districts would take a larger share of the general burden.

Sixtecn years ago Mr. Vaile proposed this partial application to railroad charges of the post-office principle of uni- 
formity regardless of distance-long before it was thought of in Hungary or in Russia, Denmark, Sweden or Prussia, which have more or less closely followed Hungary. A prominent Hungarian, Baron Huebner, was in New Zealand while Mr. Vaile was pressing his principle upon Parliament and on the country, six years before Hungary acted. For sixteen years Mr. Vaile has been urging his plan in his own country, but so far unsuccessfully. His pamphlets are a formidable arraignment of the turnpike and toll-gate system on which the railroads of the world, whether public or private, and whether in Australia, New Zealand, Europe or America, are run-the exploded, anti-post-office principle of different rates for every distance and every kind of shipment. His writings and speeches contain many sharp criticisms of the administration of the New Zealand railroads, but he is an unswerving advocate of public ownership.

The zone system of Hungary, which has been so remarkable a success, is but a mutilated version of Mr. Vaile's plan. Its results are well known. Rates were reduced to one fifth of their former average. The last year of the old system the number of passengers was 9,056,500. In I897, ten years later, this had increased to $35,245,900$. And the receipts had mounted from I 4, I I 2,000 florins to 26,95 I,677 florins. The traffic had quadrupled and the revenue doubled. Equally important is the fact that the average distance travelled by each passenger increased from seventy-one to one hundred and thirty kilometers, or nearly twice.

An almost unanimous public opinion in Australia and New Zealand supported the change we have described above from management of the railroads directly as "a political department" to that of administration by "non-political commissioners." Equally unanimous in New Zealand was the public opinion that demanded a change in 1893 back to political management. But even now that the people have 
got political management they are not satisfied, and the agitation of the Canterbury Reform League is only one of the signs of discontent. The persistence of public complaints through all these changes indicates that there is a more radical defect, and that there are deeper questions which the people of New Zealand have not yet grasped. Even under public ownership the democracy has not yet found out how to make a democratic railway tariff.

Where every mile adds to the charge rural traffic is under ruinous inequality as compared to that of the city. Though less able to pay the country has to pay the most, and as a matter of fact pays three fourths of the passenger receipts of New Zealand railways. And the country pays nearly all the freight charges: Under the zone or post-office system, as worked out by Mr. Vaile, the zone within which the charges would be the same to all points would be made much larger in the country than in the neighbourhood of the cities. To facilitate the settlement of the country, the creation of new centres and the relief of the congestion of the cities, people and goods would be carried much greater distances in the country than around the cities. This is "equalisation," but so is the post-office and the suffrage with its "one man one vote."

As the business of the roads increased Mr. Vaile would enlarge the zones, carrying people farther and farther for one fare, until ultimately there would be only one fare for any distance.

Instead of tickets, railway stamps good for any day or any direction or any place would be used to pay fares, and would be sold by the post-offices and all other appropriate government agencies. These rates when thus cheapened, equalised and simplified, would be, like the post-office rates, unalterable except by act of Parliament.

This zone or modern post-office idea has been ably advo- 
cated for the United States by Mr. James L. Cowles, in his "General Freight and Passenger Post." It has also been adopted by the railroads for their own convenience, as in the carriage of milk. The railroads bring the babies of New York their daily supply, charging one rate, no matter what the distance may be. They charge no more for milk brought three hundred miles from the western part of the State than that hauled from Orange County, a few miles out of the city.

Results in Hungary and Russia are the foretaste, like the wonderful development of the post-office, of the social, industrial and other benefits to be expected from the radical application to the railroads of the rule of uniformity of charges in every direction regardless of distance within the zones, with the whole community destined ultimately to be one zone.

New cities would spring up. People would be encouraged to settle on the land in unprecedented numbers. The workingmen could live in the country in a way impossible now, with gain of independence and earning power.

The zone or uniform system would put an end to the oppressive and unjust discriminations now so commonly exercised by private enterprise both against persons and places. There would be no possibility of the political use of railroad power, and with all this the revenues of the railroads would increase enormously, as is proved by the experience of the post-office and of the countries that have adopted modifications of Mr. Vaile's idea.

Railroad rates now are a mystery, and the officials in all countries do their best as priests of transportation to heighten the mystery and their own importance and power with it. There are, Mr. Vaile says, thirty million different rates on the Midland Road of England. Fraud and oppression go undetected in such a maze. 
"The whole present railway system," Mr. Vaile says, "has been cradled in fraud and reared in corruption, and there will be no real lasting progress in the world until it has been entirely swept away."

Under the post-office principle a child could tell the freight or fare between any two points, and no railroad official could vary the rates to build up the business of a friend or to kill off a Naboth whose vineyards are wanted.

In Hungary the zones reach only from one station to the next. But Mr. Vaile proposes that the zones be measured by distance, no matter how many stations are included.

Under the old system of post-office charges only a few people wrote letters. Now everybody writes. Mr. Vaile declares that the application of the post-office system to the railroads would be a greater event in the development of the world than the original invention of the railroads.

Here is a New Zealand idea, which, unlike most of its ideas, that country has seen put into practice, though imperfectly, by other nations than itself. But Mr. Vaile's faithful agitation for sixteen years is likely to bear fruit in New Zealand as well as in Russia and Hungary. Several Parliamentary committees have investigated his plan and reported that it should be tried. The present Premier gave it favourable consideration as long ago as I892. Every local government in the colony, with the exception of three or four, has petitioned Parliament to make the experiment. Thousands of citizens have done the same. A combination of wealthy and responsible Auckland citizens have made an offer to bear all the expense of a trial of the system on the roads around Auckland at their own risk and expense.

Almost every member of the present ministry of New Zealand has voted in favour of it when a member of Parliament. Mr. Vaile is now pushing his agitation with re- 
newed energy, and is urging with much plausibility that the experiment should be made while he is still able to superintend it, for the railroad officials who have fought it first and last would not give it as good a chance as the creator of the idea would do.

Sir George Grey, whose statesmanship was of the highest order, was one of the steadfast friends of Mr. Vaile's plan, and when Mr. Vaile was given, in I893, a handsome service of plate in recognition of his services in railroad reform, Sir George made the presentation speech and warmly eulogised his energy, ability and patriotism.

Mr. Vaile holds that the future supremacy of the world will rest in the hands of the people who best know how to build and operate railroads. The place that all roads lead to is the place that rules. Russia has adopted the zone system of railroad charges with surprising financial results. This readiness of the Slavs of Hungary and Russia to apply this new theory of transportation, multiplying many times as it does the service of the road to the people, is a warning to the Anglo-Saxon to look out for himself in the struggle with the Slav for empire. 


\section{CHAPTER V}

THE WORKMEN ARE THE CONTRACTORS

THE men who are seen in one of our pictures engaged on the Makohine viaduct are ordinary workingmen, but they are not working in an ordinary way. They are their own masters, with no contractor to "sweat" them and without a contractor's foreman to lash them with his tongue, and they are working co-operatively, taught and helped to do so by the New Zealand commonwealth.

They are working not only as workless men given work, but as landless men given land and homeless men given homes. Not only to make a viaduct or a railroad, but to change into orchards, pastures and gardens for themselves and their children the forest lands which the state will give them at the same time that it gives them a job.

One of our pictures is of an encampment where the men, and in some cases their families, are living in tents which the people had ready for them when they arrived, but which they must pay for out of their earnings.

These pictures, then, illustrate several things which soon become familiar sights to the New Zealand traveller-direct employment by the state, the abolition of the contractor, the co-operative system of public works, the relief of the unemployed, the settlement of the land, and treasury advances of money to farmers and workingmen.

All these reforms and many others were the fruit of a radical change of policy effected by the people of New Zea- 
land at the polls in I89o. The contractor was one of the men who brought this on. He had made himself almost as obnoxious to the workingman and the people as the large landowners had made themselves to the farmers. In the first session of the new Parliament one of the members of the Labour Party said, "There is no other system in the world against which there are charges so serious as there are against this pernicious system of sub-contracting. Workingmen have been robbed wholesale."

The new Premier, John Ballance, had the grievances of the contract system before him as one of the things to be redressed by the Liberal administration, and in his opening speech, bringing forward tax reform and the settlement of the people on the land as the first things demanding attention, he pointed out that the land reforms he proposed would necessarily do away with the contractor in public works.

The abolition of the contractor and the deposit of the working people who make the roads as permanent settlers on the lands alongside the roads are policies that came in together in New Zealand. In his first financial statement Premier Ballance declared that the former method of carrying on public works in New Zealand was proved to be radically vicious, since those engaged upon them were compelled to migrate as soon as the work was done. "If the public works," he said, "had been made subordinate to settlement, they would have created a demand for population. In the way they have been conducted they have been instrumental in driving it away. Not a mile of road or railway should be constructed by the colony in the future without provision being at the same time made for the location of the people engaged in the work on the land, if possible, in the neighbourhood. This may mean a radical change in the method of entering into contracts, and it certainly will entail a more direct responsibility upon government; but it 
will transform into sturdy settlers, with a stake in the country, a large proportion of those who, seeing no prospect here, are ready to embark for other lands. With a view to immediate relief and stopping the exodus, we propose to put in hand such public works as are of a reproductive character and for which moneys are available."

"We have had large estates made valuable by the construction of works," he told Parliament, "and yet we have not increased the settlement on the land. Had the system of co-operation obtained in years gone by-had lands adjoining the works been thrown open for settlement as the works progressed, had those employed shared in the profits in addition to their wages, which is the principle of the cooperative system, then, as they shared the profits, so they would have taken up the lands and settled thereon. It is necessary that a remedy should be devised for the mistakes of the past, and that remedy is the construction of works on the co-operative system, and the simultaneous throwing open of lands for settlement in the vicinity of the works. The work will not cost the colony any more, and a large portion of the money expended on the same will come back to the treasury in the shape of payments made for the purchase or rent of lands."

At the very beginning the new ministry found itself compelled to find work for the unemployed, and in doing so it instituted the system of building roads and other public works by giving contracts directly to the workmen organised in co-operative groups.

It seems at first as if it were a mere detail of administration, this making the workingmen the contractors, but it is, in truth, an essential part of the reforms in land, labour and taxation which distinguish New Zealand democracy.

The Honourable Richard J. Seldon, now Premier of New Zealand, was the first Minister for Public Works in the new 


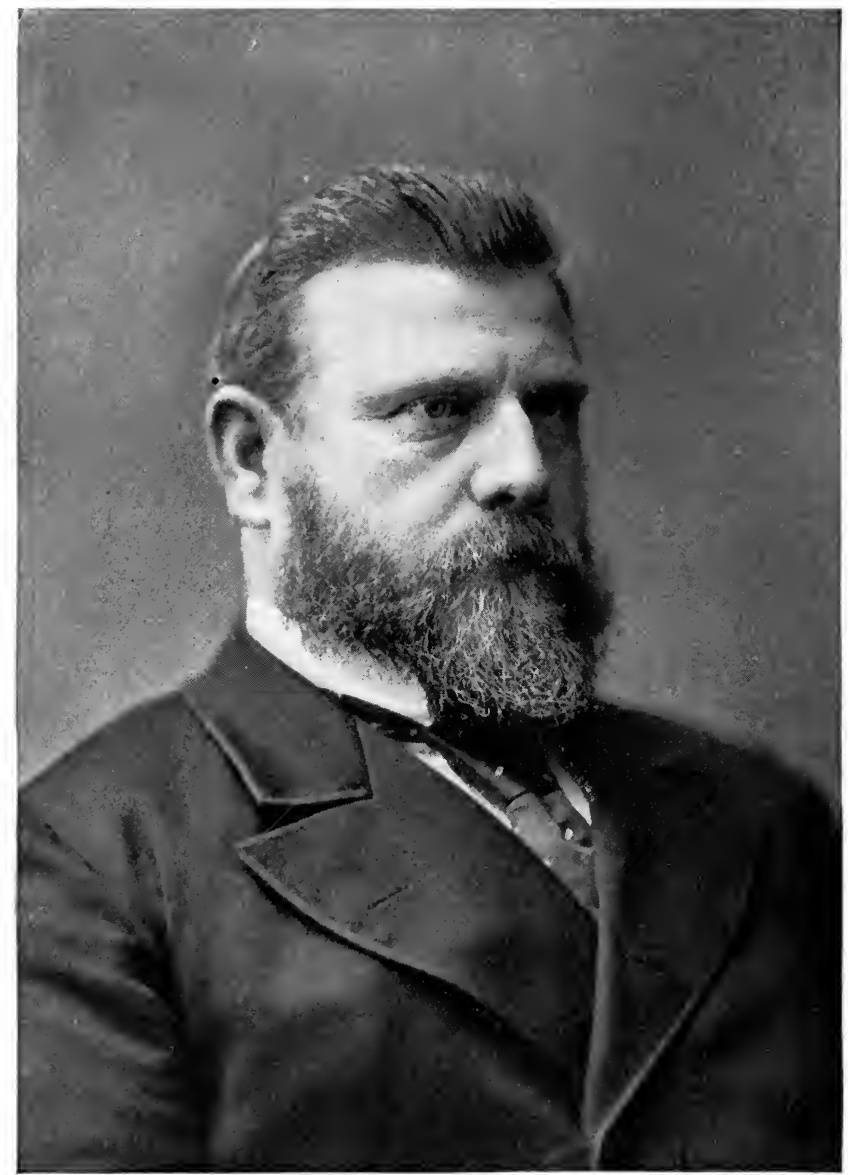

Premier Seddon.

(Page 84.) 

régime. He had been a workingman, and he is of that not too common type of rising man, one who does not rise out of remembrance of the lot of those he leaves behind him.

The most democratic country is the one which has the greatest political stability. The Liberal Party now in power in New Zealand has had the administration in its hands since the election of 1890 , and the present Premier has been at its head since I893. The election of I900 insures his tenure until r903, unless he or his party break down. This is a record not to be matched by the leader of any other democracy of the day except Mexico, and Mexico is not so much a democracy as an autocracy tempered by the greatness of the autocrat Diaz. The present Liberal régime in New Zealand is the farthest possible from resembling the one-man power that has given to Mexico so long a stretch of prosperity. But there can be no doubt that the personality of Mr. Seddon has been a factor of calculable importance in the achievements with which New Zealand to-day challenges the attention of the world.

Mr. Seddon towered among the Australasian premiers at the Queen's Jubilee, and they were all notable men. He alone of them survives politically.

Of sturdy Lancashire farming stock, young Seddon chose an engineer's trade, and with a Board of Trade certificate of his capability, arrived in Victoria in 1863 , eighteen years of age. The gold fields at Bendigo and later the West Coast gold discoveries of New Zealand in 1866 offered him chances for fortune, and New Zealand made its promise good. Any miner he saw at the mercy of a bully was sure of a champion in Digger Dick. He became a miners' advocate before the wardens who had the decision of mining disputes. Most miners dig down, Digger Dick dug up. He made himself the head of a successful mercantile business. He became a member of road boards and provincial 
councils, and of the Board of Education; he was elected Mayor of Kumara, and in 1879 a member of Parliament. He has remained in Parliament from then till now, and is the only member who has that record of continuous service. $\mathrm{He}$ is the father as well as the leader of Parliament.

Men and affairs have been his books, life his school, the House of Representatives his university. When the Liberal party came in he was made Minister for Public Works by Ballance. When Ballance died at a moment so untimely that it almost seemed as if the Liberal cause must die with him, Seddon was called by the party to its head, where he has ever since remained. $\mathrm{He}$ is fond of describing himself as the premier of the paradise of the British Empire. No one knows the political value of an idea or a man as Seddon does. His mind and his body are both remarkable. It was said of Daniel Webster that he was a steam-engine in trousers. Mr. Seddon is more than that, as becomes his later date; he is a dynamo. In addition to an extraordinary equipment of intellectual and physical vigour, he has an inborn sympathy with the people and all that concerns them. Some statesmen have democracy thrust upon them, a few achieve it, one or two in a century get it by heart or by ear. Seddon is a born democrat. He and the Honourable C. C. Kingston, Premier of South Australia when I was there, are two as fine figures as one can see anywhere among the steersmen of ships of state. Both are equally true to the cause of progress and the people, but they are of totally different types. Seddon is a new man fresh from the multitude. Kingston has a distinguished family record to live up to. Seddon is a democratic democrat, Kingston an aristocratic democrat.

Seddon is solid with the workingmen for his unvarying championship of them from his earliest days. He is solid with the country people for the tenacity with which he has 
fought for their land and tax and money reforms. He is solid with the progressives for the courage and initiative of his radicalism. Seddon is always in the advance. It would not have been surprising, after the rapid onward march of the last ten years, if he had wanted to rest on his laurels. But all through the last campaign he was throwing out intimations of a still more forward policy. $\mathrm{He}$ does not hesitate to assure the great landlords that they may expect still heavier taxation. He has warned the coal ring that he is ready if necessary to put the state into the coal business, and the shipping ring that he will favour the nationalisation of steamships if needed to curb their exactions.

$\mathrm{He}$ is not a statesman of one idea, not even of so good an idea as democracy. When I asked him how the countless things were going to get themselves done which ought not to be left to competition, but could not be done by the state because not even in New Zealand is the state far enough advanced to undertake them, he replied, "Co-operation will take care of them." Though he has probably never had time to read a book on co-operation, he reached by intuition the conclusion which is developing in the minds of our best political philosophers, that co-operative and democratic industry are the two hemispheres which will make up the social world of the future. While waiting for the nationalisation of the coal mines he leases a mine under the control of the state to a coal miners' trade-union to be worked co-operatively.

Seddon is strong with men and women alike, and he softens the antagonism even of political opponents by a policy which he expresses in a favourite phrase, "We must take a kindly view of human nature." His defence of the old-age pension and the co-operative works and other humanitarian measures is always touched by a tender sym- 
pathy for the old and unfortunate. Though a paragon of physical strength, he is never ashamed to show that sentiment plays a large part in his views of public matters and that he has a head that feels and a heart that thinks.

The first discovery he made on taking his office as Minister for Public Works was that, although the contractors who were doing the public works were forbidden by the explicit terms of their contract to sub-let, they were practically all sub-letting, and, what was worse, the public officials were conniving at it and treating the prohibition as a dead letter.

Minister Seddon put a stop to all this. "It was the sweating system," he said, "in its most flagrant and baleful aspects." These contractors took work at a price out of which they could not make a legitimate profit, and then sublet to make money at the expense of the workman. The last state of the district which at first had congratulated itself on getting an appropriation for some road or bridge was often worse than the first. The contractor would bring his own men with him; the news of the improvement would attract a large number of outsiders; the contractor would then run away, and the people would be left with the labour problem tripled. They would have on their hands their own labourers, those whom the contractor had brought in, and those who had come, as the Australians say, "on their own." Meanwhile, in cther districts, no labourers could be got. The tradesmen who supplied material to the contractors and subsistence and other things to the men had frequently to go unpaid. The work was done in a slovenly way. It was almost always delayed.

The contractor used to try to get on the right side of the engineer or surveyor and obtain extra allowances. He would put on an especially good man or two in each gang, pay them more by private arrangement, and set a killing 
pace for the other men. "He would establish a store to soak up the wages; he would have a sardine can in front and a whisky bottle behind."

"We made up our minds to stop that," Mr. Seddon said, "and introduce the co-operative method which is now in use." An affair soon occurred to make a practical issue of the evils of the contractor system and call for an application of the principles of the new party.

The contractors who had undertaken to build the Ngakawau railroad extension to Mokihinui under a very liberal arrangement, no deposit, for instance, being required, threw up the work, perhaps with the expectation of forcing still better terms. Going to Westport, Minister Seddon found a large number of men who had flocked there from different parts of the colony, expecting to get employment on the construction of this railway. To avoid the delay that calling for fresh tenders would have involved, he decided to let the sections referred to-three in number-to the men themselves, and on a new plan-on the co-operative principle. He asked the men to divide themselves into parties of about fifty each, and to select from each party certain trustees to take the work from the department in the ordinary way, but the work itself to be done by the whole of the men, each one having equal interests with his fellows, the price to be fixed by the engineer in charge of the work. On this plan the men went to work in a few days. As often occurs when new methods are adopted, there was a little friction at first, and a little difficulty in the classification of the men. The strong and able-bodied did not altogether like to work for the aged and the feeble. Both the men and the work were thereupon classified-the lighter work was given to the aged and less capable men.

"Under the previous system," Minister Seddon reported, "the government had been paying only \$1.I2 a day to 
the men. The state received but a poor return for its pittance, as no interest, of course, was taken in the work. Now the men-some seventy in number-are paid so much per chain for the work, and the total cost has not exceeded what it would have been had the work been done by contract, and the men employed are well satisfied. Men who had been working under the old system, and whom the overseers had considered not to be able to do a fair day's work, and who were consequently not worth even the $45.6 d$. per day which were paid, have turned out excellent work, and are moreover anxious and eager to do it. Instead of being disappointed and complaining, as they were in the past, they have been made happy and contented, and have been able to put by a little money. An entirely new phase has, in fact, been put on the whole business."

In reporting the success of this experiment to Parliament, Minister Seddon prophesied that it would "ere long be recognised as the broad system on which our public works should be constructed."

This anticipation has been realised, and from year to year since then more and more of the public works have been taken from the contractors and have been given to co-operative gangs of workmen.

Expensive public buildings are now put up in large part in that way all over New Zealand. The government printing office in Wellington is an instance, and even complicated bridges are now erected by co-operative bodies of mechanics and artisans.

There were mistakes at first, of course. The co-operative parties were made too large. It was found impossible to get thirty or forty men who were so nearly equal that they could work together harmoniously. The size of the groups was reduced until now the minimum is four. The officers, too, accustomed to deal only with contractors, found 
this an entirely different thing, and found, too, that the subdivision of the work and increase in the number of contractors-for every party of workingmen was a contractorwas a serious addition to their labours.

One very practical advantage was experienced in the first year. It was found necessary for financial reasons to cut down expenditures in I89I. Under the contract system this could not have been done without incurring claims from the contractors for heavy compensation, but the agreement with these co-operative groups reserves the privilege of suspending operations at any time without any liability for damages.

One of the apprehensions with which the scheme was regarded was also proved to be groundless. It had been predicted that political pressure would prevent the discharge of men and compel employment to be given out for which there was no real need. But this was put to the proof by the discharge of a large number of men engaged on the cooperative works without the slightest suggestion of resistance or any political pressure by the men.

In the first year the system was extended from the construction of ordinary roads and the earthworks of railroads to larger matters requiring skilled labour. Railroad culverts of brick and stone and concrete and some small bridges were successfully attempted. The laying of the rails and the building of stations and similar work were still let out by contract.

The minister adhered to the principle he laid down at the commencement, that work should be done co-operatively only if it could be done at no greater cost to the public than by contract.

He was able to announce in his report for 1892 that "the works are carried out in a more satisfactory manner than under contract and at no increase in cost." 
The men put at work in this way are uniformly unemployed, sent out by the Labour Bureau. Work on the Mokau section of the North Island Main Trunk Railway was given in this year co-operatively to one hundred and fifteen men, seventy-five of whom were unemployed, from the agency of the National Labour Bureau at Auckland. The men were divided into parties, usually of about ten each, and the work was let to them in pieces of various lengths, at prices fixed by the engineers. Their average net earnings were $7 s$. to $8 s$. a day for eight hours.

This success is especially noteworthy in comparison with the failure of the more ambitious co-operative villages attempted by South Australia and New South .Wales-failures perhaps because more ambitious.

It is not only the unemployed from the cities that benefit by this plan, but especial pains are taken to make it feed with work the small settlers already given homesteads and needing more income to supplement the produce of their farms.

By 1893 the system had been extended to the greater part of the public works. It was found to be as well adapted for laying the permanent way and constructing station buildings as for the earthworks, culverts, etc., which were all that had been at first ventured upon.

The extension of the co-operative method to the more difficult parts of railroad construction, like bridge building and track laying, proved so successful that in I893 Mr. Seddon had the courage to carry it a step further-that is, to public buildings-and again with the best results.

The first building attempted co-operatively was the Te Aro railway station at Wellington. The supplies of timber and other materials for the buildings were obtained by tender, but the work of erection was let to co-operative parties. The new government printing office, one of the promi- 


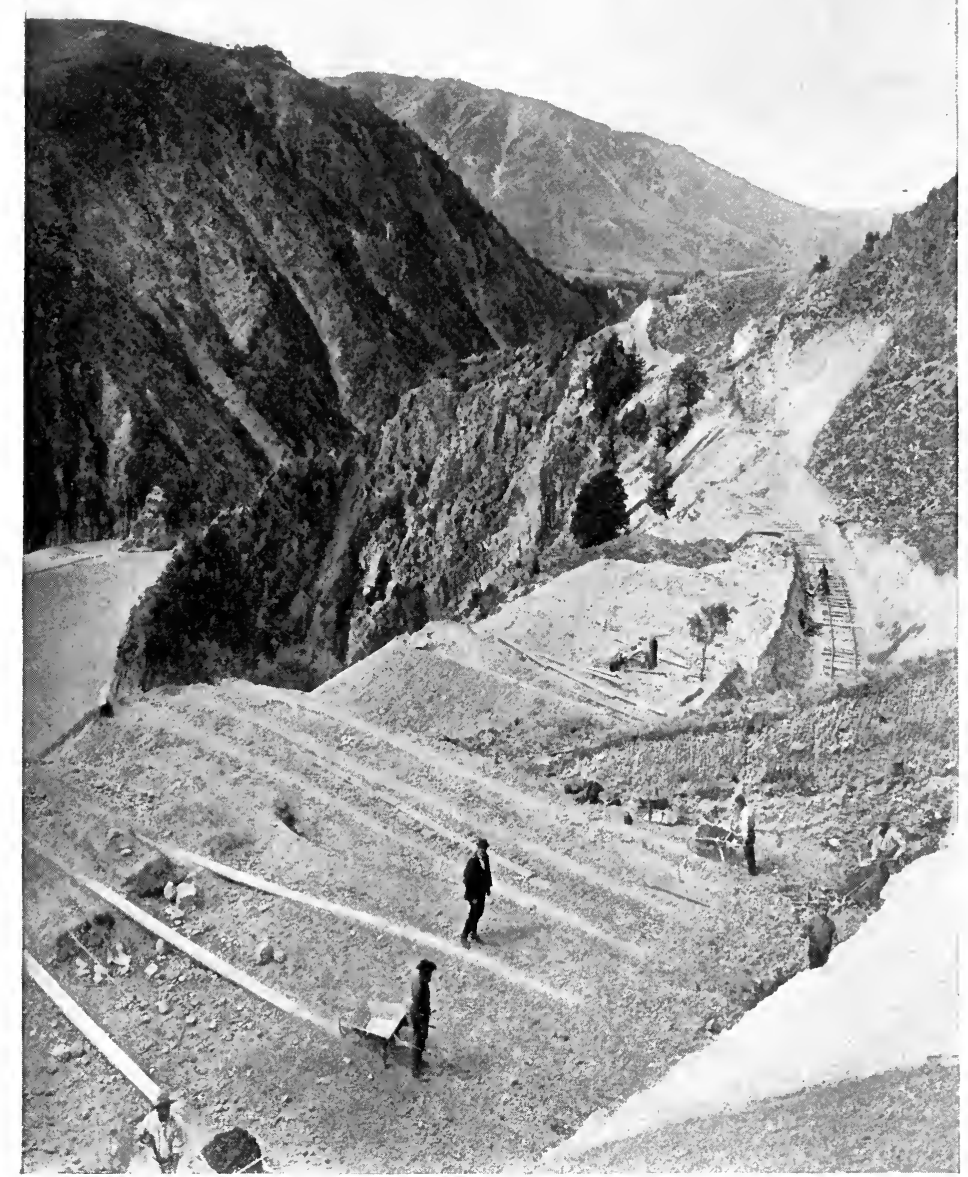

A Co-operative Group at Work.

(Page 92.) 

nent buildings of the capital, Wellington, adjoining the Government House, was begun in 1895 co-operatively and carried through to completion. The levelling of the ground and the preparation of the site was given to co-operative labourers; a co-operative group of bricklayers took the contract for the brickwork; the woodwork was let to a group of carpenters; similarly, the plumbing was given to co-operative plumbers, and so on. As the Minister for Public Works said with pride, "Every brick was laid in co-operation." But he points out that this method cannot be as easily or successfully applied to buildings as to the simpler work of railways, and the like. When the Supreme Court at Wellington was to be painted, the lowest tender from contractors was almost double the price at which the work was finally done by painters employed co-operatively.

In one or two cases the workingmen clubbed together and made gifts to the engineers in charge. This kind of cooperation was not what the government was fostering, and notice was given that no more of it would be allowed.

The state took parental notice of the fact that some of the men, unable to endure the transition from the complete impecuniosity of idleness to the sudden wealth of a government job, were spending their money foolishly. It instituted the system of remittances to the "folks at home," which are spoken of in another place.

The next winter, I894, was a very hard one. The harvests had been exceptionally bad, and this, with declining prices, brought the industries of New Zealand to a low ebb and threw many out of work.

The pressure of all this was felt at once by the Public Works Department, which recognised in Mr. Seddon's words that it devolved upon the commonwealth to make provision to alleviate as far as possible the wants of those who, through no fault of their own, were idle. 
As the settlement of the people on the land is the keynote of this policy, as of all New Zealand policy, Minister Seddon, in getting his unemployed to work in this emergency in the winter of 1894 , put them on roads and on clearing, and other preparation of Crown lands for settlement. The farmers had made complaints in previous years that the absorption of the floating labour had been an injury to them during the summer months. This year the need for help in the harvest fields was met by slackening the operations on roads, railways and other works and setting the men free to go to the farmers.

The fame of the new method had gone abroad, and the minister took a justifiable pride in making it known that he had received official inquiries from Victoria, New South Wales and other colonies, and from the American and British governments. But his confident expectation that the co-operative method would be largely adopted in other countries has not been fulfilled.

One of the reasons for this disappointment is that this reform is of little significance by itself. It is only one egg in a nest of reform eggs. It means little to the country that is not prepared to put forward with it a sincere and extensive programme of the restoration of the land to the people and the people to the land and of reproductive public works to make the people and the land ready for each other.

By 1894 it had become a regular thing that the track laying and the construction of the railway stations and of all but the most difficult bridges should be done by cooperative labour. This year eighty-three co-operative contracts were made for railway sleepers, nearly all of them with settlers and workingmen. Post-offices, asylums and other public buildings were being put up and repaired wherever possible by the "co-operative contractors." Times were again hard in the winter of 1895 , and again the 
government, owing to the dearth of private employment, increased its co-operative force. The criticism made at first that the work would be more expensive than if done by private contractors had been proved mistaken, and it was now succeeded by the assertion, based on the published reports of the average earnings of the men, that the state itself had become a sweater and was paying the men too little. It was true that the earnings of the men often seemed to be less than those paid by contractors, but the explanation of this when made only served to increase the popular appreciation of the plan. Many of the men employed were old, many wholly inexperienced, many were defectives, many were skilled artisans, like the printers, who had never before done the kind of work they were now offered. Of course the average earnings of such a force would be less than the average of competent men picked by contractors.

Capitalism refuses standing room on the industrial footstool to old men, often to middle-aged men, and even married men, but the state in New Zealand finds that they have an economic value, and for the sake of humanity and the social economy gives them a chance. In a speech at Auckland just before election, the Premier, referring to the announced purpose of the Opposition, if successful, to do away with the co-operative system and return to the contractor-"to the days of sweating and of truck stores kept by contractors' relatives"-made it a strong point of his appeal to the people to sustain his administration, that, while under the contractors, old men could not get work, they have on the co-operative works just as much right as young men.

A very happy idea was put into operation this year to facilitate the conversion of the co-operative workingmen into farm settlers. Wherever land was available for set- 
tlement by these men, their working time was divided between the government and the farms allotted them out of public land. The married men were to have four days' cooperative employment in each week, and were to be allowed to absent themselves the other two days to improve their farms. Single men were to divide their time equally. This reduced the outlay on public works, and at the same time hastened the permanent "deposit of the men on the land."

Almost every item in page after page of the reports of the Public Works Department as to the railroads, bridges, station houses, roads, jails, asylums, court houses, postoffices, quarantine buildings, and official residences contains a line like this: "The work is being done on the co-operative principle, and with satisfactory results."

Until I 896 there had been no attempt at iron bridge construction, but when the tenders for the Mahokine viaduct were received and the lowest was found to be several thousand pounds in excess of the chief engineer's estimate, it was decided to carry out the work under co-operative contracts.

Arrangements were accordingly made for the supply of the iron and steel and other material, and co-operative contracts were let to groups of labourers for the excavations, and to masons for the building of the concrete piers and foundations, and to iron and steel workers for the preparation and erection of the bridge itself. These different kinds of contracts were let separately, for it is not found advisable even in democratic New Zealand to have labourers and mechanics in the same party. The structure is costing less than if erected under the lowest tender offered, and a bridgebuilding plant is being acquired which will be available for use in the erection of other viaducts and bridges as they may be called for.

The co-operative system by this time had been in operation for five years. The total expenditure on these works 


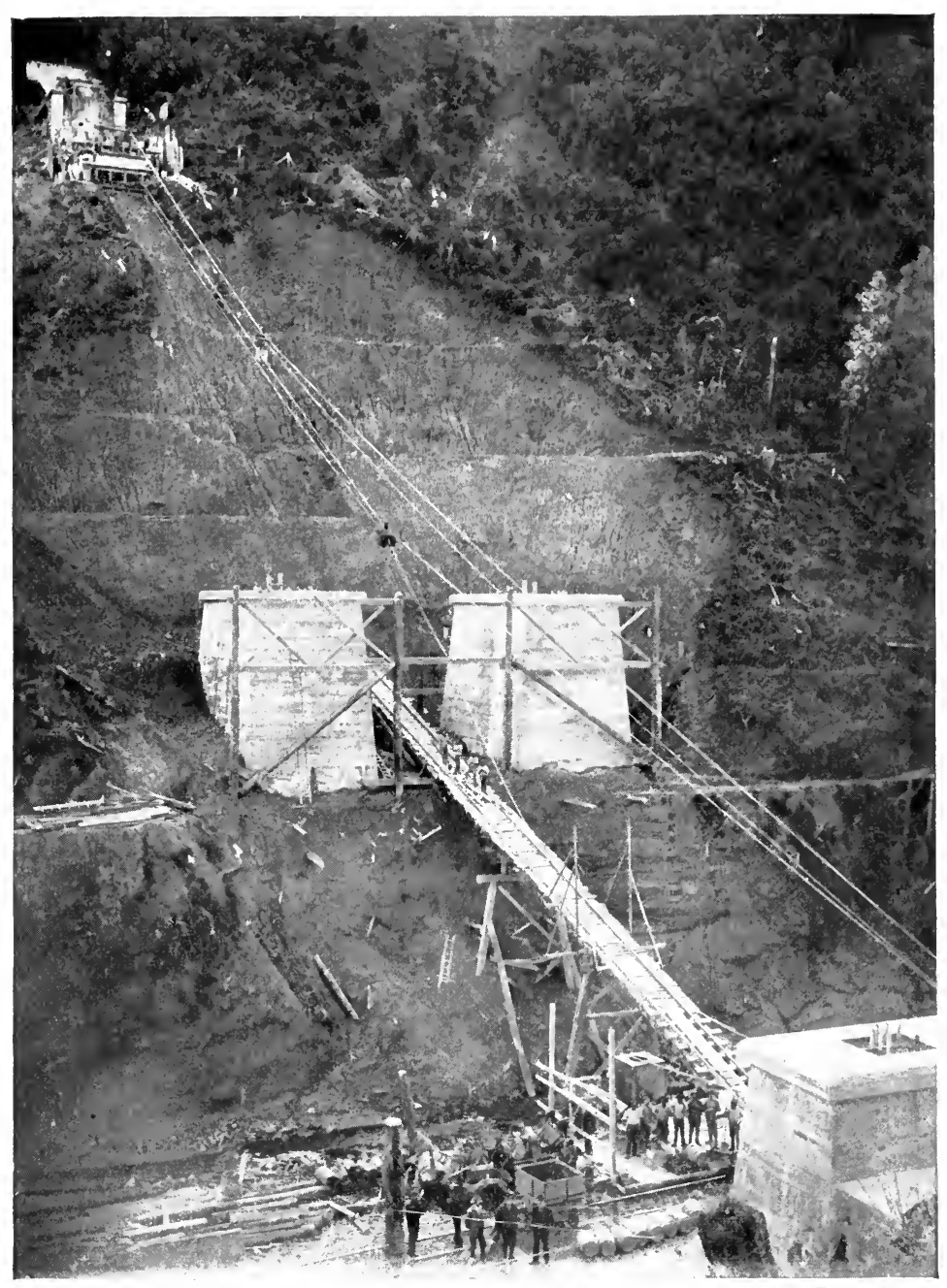

Unemployed Building the Mahokine Viaduct.

(Page 96.) 

was $\$ 4,649,8$ Io, nearly equally divided between the Public Works Department and the Lands Department, and of this sum no less than $\$ 3,054,705$ had been paid directly to the workingmen as the value of their labour. There had been constructed altogether co-operatively I 72 miles of railroads, I, I80 miles of other roads, and a great variety of public buildings. There had been employed altogether 8,259 men, about equally divided between the two departments.

It will be worth while to note the average earnings a day by the different kinds of workingmen thus engaged, remembering that this average is the average for elderly men as well as young men, and delicate men as well as hardened navvies. The ordinary day labourer had earned an average of $7 s .2 d$., or $\$ 1.89$; the carpenters $8 s$. I $d$. to $8 s .8 d$., or $\$ 2.02$ to $\$ 2.16$. The masons and bricklayers Ios. $8 d$., or $\$ 2.66$, the plumbers Ios. Iod., $\$ 2.70$, and the plasterers I2s., \$3. To show the comparative cost of railways constructed under the two systems the government has prepared a table giving the mileage cost of railroads built under similar conditions by contract and by itself under the co-operative system. In every case the railroads built co-operatively cost less. The smallest difference was \$33,570 a mile by contract against $\$ 33,460$ by co-operative labour, and the largest difference was $\$ 43,910$ by contract against $\$ 39,575$ by co-operation.

Of course the state has to go without the gains it might make when some contractor has to finish his job at a loss, but since in that case the contractor almost always goes "bung," as the Australian phrase has it, or if he has means and influence will usually find some way out of his embarrassment, the common result of speculating on the bad guesses of a contractor is a loss, not a profit. The public gets his losses and never shares his winnings. In one of the New Zealand railroad works the track was to have 
been ballasted with broken stone at a cost of about sixty cents a yard. Just at the moment when the ballasting was about to begin a deposit of scoria ash-a much superior article-was found, and so conveniently situated that it cost only twelve cents a yard delivered. As the work was being done under the co-operative plan by the state itself the saving by this discovery all went, not to some fortunate contractor, but to the taxpayers.

The new underground rapid transit road now being built in New York will destroy miles of the Broadway Boulevard parkway, with beautiful trees, lawns and shrubs, made at great expense of time and money. The engineers in laying out the course of the work, evidently neglecting to walk over the route, forgot the parkway and put the tunnel directly under it. The construction will therefore destroy all this beauty, which might have been a heritage of joy forever. To change the plans so that the tunnel shall go to one side and the parkway be saved would be the simplest possible matter; it would involve only a few days' calculations in the engineer's office. If the city were building the tunnel this correction would undoubtedly be made and priceless values be rescued, but the work is in the hands of a contractor, and the slightest delay or the least change in the plans would be at once seized upon by him as a basis for claims of millions of dollars' damage. The people must stand helpless and see their boulevard ruined forever.

The government cannot hurry a contractor, but it can expedite itself as it will. If any emergency requires that the number of men be increased and the work hastened, it has the thing in its own hands under the co-operative system, and there is no one to demand that bugbear of all who have to deal with contractors-_extras."

Another point of practical importance is the superiority of material. Under co-operative work the government, as 
we saw in the Makohine viaduct, finds its own materials and naturally selects the best. The workingmen are not instructed to stint material to make savings for the contractors, and the official overseers prevent waste. The democracy puts no whiting into its paint instead of white lead, and does not use the poorer brands of cement or iron. Nor does it build its walls dry in the centre, nor fill them in with brickbats. The men work better and faster with sound materials than with rubbish.

As the men are the contractors themselves the workmanship put in also is of a superior kind, for it is the taskmaster himself who does the work. Under the contractor or the public superintendent the loafer has only the overseer to look out for, but under the co-operative system every one of his associates is an overseer, with the keenest self-interest in seeing that every one of the group does his full share of the common task.

There are "privileged classes" among the men who are thus employed-men who have never before been on public work, men who are residents of the district where the work is to be done, married men, men who have been longest out of work-these take precedence. If there are more men than are needed, the choice is made by ballot instead of "pull," and the men superintend the ballot themselves.

The men who are seen in the co-operative groups are the men for whom the Improved Farm Settlements have been devised. It will be told later how their families are brought with them if desirable, or, if not, how the savings of the head of the family are remitted to his dependents and how they are helped to farms and encouraged to work them. To all this is to be added the advances to settlers and the bonuses, instruction, and the other assistance given to their production by the People forming with them a part- 
nership, “Government \& Co., Unlimited,” especially if their products can be branded "Approved for Export" and sent to England to add to the funds available for the payment of the indebtedness of the colonies to England.

So far as the partnership of the men is concerned, these co-operative groups much resemble the "butty gangs" of the miners and other workingmen known to all familiar with the north of England. The public works officials of New South Wales claim that they had introduced the "butty gang" into their operations even before New Zealand had domesticated it as the "co-operative group," and that it is still largely used by the Department of Public Works. The co-operative principle was introduced in I89I into Victoria, in imitation of New Zealand, but neither there nor in New South Wales is it a part of that broad system of settlement on the land and the conversion of penniless and workless men into householders, property owners, and tax-paying citizens, with a stake and a beefsteak in the country, which makes the New Zealand adaptation of the scheme so statesmanlike and remunerative.

All the colonies are more or less displacing the contract system by that of construction by the government itself with its own workers, and this is a step toward making the men contractors, for it involves the abolition of the middleman. A select committee of the New South Wales Parliament in 1897 investigated the results there of having railway and other work done without contractors. In its report the committee says that the work done by day labour is as well done as similar work under the contract system. The cost has not been increased, and in some cases has been materially less, while the danger of litigation, an item of considerable importance, has been entirely abolished. The railway authorities and the travelling public have both been convenienced by the greater safety for travellers and greater 
celerity in execution of work, which comes from the fact that the commissioners are able to keep everything under their control. The committee therefore resolve that this method of work is in the public interest and recommend that it be further extended.

New South Wales is planning another incursion into the field of the contractor and sweater. I found the Secretary of the Public Service board, Mr. T. A. Coghlan, preparing plans for a clothing factory for the uniforms of its men. The government will take one of its buildings on the quay at Sydney for the enterprise. When it is once in successful operation, the railway department, the postoffice, the army, and many other institutions, like the asylums and hospitals, will make their contracts for uniforms here, and another province will be lost to "the competitive system."

The Contractors' Association in New South Wales, when I was there, resolved at one of its meetings that they would combine to get a member of Parliament to represent them in their opposition to the continuance of the "direct employment" policy.

These co-operative works in New Zealand, wholly a creation of the Liberal party, have of course been bitterly criticised by the Opposition. The former Minister of Lands under the Conservatives avowed himself in Parliament opposed to them in toto, and declared that "under this co-operative business we have to pay much more with very poor results than under the contract system." Another leader of the Opposition described the expenditure under it as a "huge bribery fund used for political purposes." One of the campaign devices of the Conservatives in the election of 1899 was the scattering of circulars on the highways before the election denouncing the co-operative system in the interest of workmen, and calling on them to vote for the party which 
would abolish it. The Premier, the Honourable Richard J. Seddon, declared in his campaign speeches that he would stand by co-operative work as long as he remained in New Zealand.

In the last session of Parliament-1899-the Minister for Public Works, the Honourable William Hall-Jones, announced that so far from intending to abandon the system, as had been charged by the Opposition, the department was extending it, and continued to find that the results compared favourably with those of the contractor system. If there is anything in public administration that the people are more familiar with than another, it must be work of this kind, which is done in the open, on the roads, bridges and public buildings, which the people pass every day. The overwhelming and unprecedented victory of the Liberals showed that these criticisms made no impression on the constituencies.

In referring to the operation of Sir Julius Vogel's scheme of public works, under which ten millions of pounds were borrowed in 1870 to build railroads and assist immigration, Premier Ballance said: "The great public works policy was built on a false foundation, for it was not built on the industries of the people.". This co-operative work system is built directly on the industries of the people.

An influential member of the Unemployed Advisory Board of New South Wales, the Venerable Archdeacon Langley, in a report of labour conditions in New Zealand, which he made in 1899 to the board as a result of a visit of investigation, credits the co-operative contract system with the fact that since its adoption eight years ago there has been no unemployed agitation in New Zealand. He quotes from a leading dignitary of the Church of England in New Zealand the opinion that though the.co-operative works are more costly than the old contract system, they save all this 
extra cost and more by the absorption of the unemployed and by the rescue of the men and their families from pauperism.

We do not usually feel it to be necessary to be greatly impressed by eloquent phrases in official literature about the "dignity of labour" or the "interests of the people." These have been the cloak of selfish exploitation in all ages, whether of kings or parties. But we must acknowledge that its deeds entitle its words to our respect, when the New Zealand government in its description of this system, says, "The co-operative system places the workman on a much higher plane and enables him to comprehend more fully the dignity of labour. Under the co-operative system every workman is a contractor and has a personal interest in the economical and the successful carrying out of the work. $\mathrm{He}$ is also his own master." 


\section{CHAPTER VI}

\section{TAXATION TO BURST UP MONOPOLIES}

"The great curse of New Zealand," declared one of the members of the reform Parliament of 1891 , "is the variety of its monopolies." There were monopolies in earth, fire and water, since there was a shipping ring, and one in coal, and there was monopoly in money and in other things. The incredible extent of that in land is shown in another chapter. In I89I there were sixteen hundred persons who held eighteen million acres $2 f$ land; eleven men owned land worth twenty-four millions of dollars; one hundred and seven owned land of the value of thirty-five millions of dollars.

Would-be settlers, in search of homes and farms, would pass, here, a tract of seventy-five thousand acres of the best of land, with a population of only twenty-nine men, women and children; and, there, another of two hundred and fifty thousand acres of good land, with only sixty-five people. They also saw, as they went about, railroads, wharves, highways and bridges, made in large tracts of waste land. Where the least population was, the national and local authorities of the old régime had spent vast sums for these works, under the instigation of landlords not "looking backward," like Mr. Bellamy, but looking forward to more and more unearned increments. A railroad was sometimes built at the public expense simply to bring the wool of one great estate to market. 
The Maori war debt of several millions represented also money expended to get more land for the monopolists. The cost of these wars and works had to be borne, through the tariff, by the masses of consumers, and, through the property tax, by the masses of producers; always the masses-the carriers always of the "white man's burden."

The great fortunes of New Zealand grew out of the increased value given to the land of the few by the labour, taxation, borrowed money and public works of the people; and these few men contrived the property tax, falling mainly on improvements, and escaped their fair share of the public burden, as their land was largely unimproved.

"Every one knows," said Mr. Seddon in Parliament, "that the curse of this country is the companies holding large estates; these estates are increasing; the companies do not die, and there is no provision to compel subdivision."

"The first plank in the Liberal platform," said Premier Ballance in I891, "must be the land question."

Land monopoly was to be the first to be attacked, and the first means of attacking it was that ancient, constitutional and inalienable weapon - the tax.

Accordingly, Mr. Ballance put forward the taxation of land and incomes as the first measure of his programme; and both of these taxes were made progressive-growing heavier as the taxee grew richer.

This was put before tariff readjustment, or labour laws, or compulsory arbitration, or the resumption of estates for settlement, or state banking, or any of the other reforms in which notable work has since been done. There was a triple purpose-fiscal and social-to be achieved by the new taxes. First, revenue; second, to make the landowners pay their share of the cost of government and of the public works, which had made them rich, and third, to break up the monopolies. 
The Premier was explicit: "The graduation of the taxes is to check monopoly." He did not shrink from raising the issue between the rich and the poor. "It is for the people to say whether the land out of which all must live shall be widely distributed, or whether it shall be held by a privileged number. Our policy raises the issue in the most practical form."

In closing the debate he said, "I care little for the mere capitalist. I care not if dozens of large landowners leave the country. For the prosperity of the colony does not depend on this class. It depends upon ourselves, upon the rise of our industries and upon markets being secured in other countries, and not upon any such fictitious things as whether the large capitalists remain or leave the colony. They are merely accidents of the situation. They are often but excrescences which afflict our industries."

"We propose," the Minister of Labour, the Honourable William Pember Reeves, afterward author of the Compulsory Arbitration Law, said in the same debate, "to take off taxation from the small land proprietors and put it on the large owners."

"Our object," Mr. Seddon said, "is to prevent the mass of the people who own no land from becoming serfs." $\mathrm{He}$ declared that "most of the fortunes that have been made in this country have been made by the increased value given to the land, week after week and year after year, by the people of this colony, and not by any exertion or any brain power on the part of those that hold the land."

"The new legislation," a labour member said, "was notice to capital for the first time in its history that it is no longer an autocrat."

This member expressly defended the progressive feature of the proposed taxation, on the ground that it gave effect to the principle "that those who have great wealth shall bear 
a far greater proportion of the burden of taxation than they have hitherto borne. Capitalists will have to realise that if they fail to recognise their responsibilities and obligations to their fellowmen, the state will take care, by a progressive method of taxation, to make them do so."

He declared himself willing to have the process called "confiscation," "bursting-up," anything, so long as the result was achieved-that the land should be divided among the people.

The Conservatives, who had been having everything their own way in New Zealand for so many years, got some very plain talk from the representatives of the people in the new Parliament. The orators of the French Revolution were not plainer, but the New Zealand methods fortunately were not those of that unhappy episode.

In defending the heavier taxes to be imposed on the larger estates, Mr. Reeves said: "The large estates are represented by the very last class which should dare call upon the state for consideration. These estates, whether partly or almost entirely unimproved, are a social pest, an industrial obstacle and a bar to progress. The party we represent does not want large estates, and this graduated tax is a finger of warning held up to remind them that the colony does not want these large estates." Mr. Reeves pointed out that the public works policy had been made "lop-sided." It had built railroads and assisted immigration, but had failed to help the people to homes and livelihoods on the land, and this was directly due to the opposition of the owners of the large estates. He dwelt on "the evil these large estates have been, on the disappointed hopes, the checked progress, the ruined industries and the broken hearts caused by the depression of the colony during the last dozen years." New Zealand had seen the spectacle, extraordinary for so young a country, of thousands of its most vigorous people going 
abroad in search of work and land. He credited this exodus to the monopolists: "Thousands of families and tens of thousands of fellow colonists have been driven over the sea, just as surely as the people of Russia are driven into exile by the edict of the Czar." "It is not to ruin them," he said, "but to bring home to these gentlemen that they have done a wrong to their fellowmen, that we propose the graduated tax on the large estates."

To prevent Newest England from sinking into the condition of the Old England was the frankly avowed purpose of the new taxes. The Premier, in proposing the graduated taxation of land and incomes, quoted what he impressively called the "appalling facts" of the pauperism of England, where one half of all the population who reach the age of sixty-five also reach the poorhouse, and where "in London one person in every five dies in the workhouse, hospital or lunatic asylum."

"Well," he exclaimed, "may we question the economic and social system of which this is the product!"

He called on Parliament by the adoption of these measures to take a step toward "establishing our civilisation in this new land on a broader basis in a deeper sympathy for humanity."

His closing words were, "Nor need we fear that in pursuing this we shall fail to reap that material prosperity at which financial systems aim. The wide diffusion of wealth and industry among the people is the surest guarantee of a buoyant revenue and wealthy exchequer. I see only the closest relationship between a people well-placed and fully employed and a state enjoying the highest credit and discharging every obligation, moral and legal, imposed upon it."

No scientific student of the land, labour and fiscal institutions of New Zealand could omit an examination like this 
of the economic pressure that produced them, and of the opinions and sentiments which this pressure had developed among the people.

Laws are but the statutory phrasing of the ideas of selfinterest of those who enact them; and as the laws are too often an inadequate expression of these ideas, such sentiments and opinions as are revealed in this presentation of the state of mind of the New Zealand democracy is really of as much moment to the scientific student of the institutions as the institutions themselves, perhaps of more.

The people saw their exploiters using the familiar instruments of government, and had the wit to see that to turn the same instruments against the exploiters was what was needed, not a wholesale construction and reconstruction of society.

Taxation had been one of the most effective of these instrumentalities of the monopolists, especially the "property tax." The people therefore demanded first, the repeal of this tax; and second, and most important, the substitution for it of a tax which should bear specifically on the monopolies. This property tax, like that still in vogue in many of the commonwealths of the United States, had become exceedingly unpopular, and its abolition was made one of the chief issues of politics.

The farmers, especially, were against this property tax. They grew infuriated at seeing that, as they acquired more land, built more barns, added to their stock, and, through the taxes they paid, opened roads and improved the country, their taxes were increased, while the owners of unimproved great estates next to them, rising rapidly in value, paid no more and sometimes less, and year by year bought out their overburdened neighbours.

In the campaign of 1890 the discriminations of the property tax were the subject of discussion on every platform in 
the colony. It was shown to be crude and oppressive. It taxed men who were losing money as much as those who were making a profit, and, so, taxed misfortune. Enterprise and energy were dampened by a system which made a man pay as much when he was running behind as when he was going ahead. It taxed not only industry, but the materials of industry. The professional men whose property was in their earning power escaped, while the poor settler was fined a large slice of his income to pay for their share of the government and his own. In taxing unprofitable property and unsold goods, it preyed with especial severity on the small traders and the small farmers, and made the owner pay, over and over again, on that which paid him nothing.

For the men who were heavily in debt but had to pay on the full value of the property that stood in their name, notwithstanding the mortgage, the property tax was confiscatory. It discouraged improvements. It took out of circulation the money that was needed in business. It was a direct tax on labour. It was unjust, inquisitorial and uncertain. It crippled the mining industry in many districts by its annual demand for tribute from capital that was unproductive. It discouraged enterprise by putting a tax on new industries before they had begun to yield return.

The tax was almost ruinous in its exactions on the owners of property with small incomes. Business men or farmers who ventured money on experimental improvements had to pay the property tax on the money invested, though the experiments were often failures and the money hopelessly sunk.

But it was the poor settler who was the heaviest sufferer. There was an outcry from the small people from end to end of the country. They toiled and struggled to improve their small properties, and the moment the improvements were made, down came the property tax commissioner. "I 
have seen," said a member in Parliament, "over and over again a man and his wife take up some small section and put up frame buildings and carry out other improvements. The land previously liable to a tax of only one pound in its unimproved state now became liable to an amount of four pounds and over. At the same time some one alongside, who had merely bought his land for speculative purposes and allowed it to become a rabbit warren and a nuisance to his neighbours, finds his taxation lower simply because they had improved their land."

On these lines the policy of the property tax was threshed out from one end of New Zealand to the other in the campaign, and when the election was held, the tax was buried forever.

The New Zealanders did not dream of tearing the house down because they woke up to find it full of embezzlers or burglars. They proceeded to put the intruders out, and their economic common-sense saw that for the kind of burglars and embezzlers that we call monopolists there is no ejector equal to the inalienable and irresistible power of taxation which the monopolists cannot withstand and which the state can never lose.

"There is no contract, expressed or implied," Premier Ballance said, "which would be superior to the safety of the people. The safety of the people is the supreme law."

I found it universally avowed in New Zealand that the present taxes are only the beginning. There is no point of policy for the future more firmly fixed in the popular mind than that these taxes shall be increased until they have done the work for which the reform was begun.

"It is the thin edge of the wedge," one of the ministers said to me. "We had to get that in first. It will be easy enough to increase the taxes on land and incomes. A little bill of a very few lines will do that." 
"One of the most effective features of these taxes," another high official said, "is not that they are heavy, for they are very light, but that they can be so easily made heavy by a few words of legislation."

The present Premier, Mr. Seddon, is never at a loss when challenged to show where he can find the revenue necessary to maintain his old-age pensions or to institute some of the other reforms he meditates. He keeps constantly in the cheerful view of the people the availability of higher taxation of the larger estates and the larger incomes.

The new taxes were not put forward as ideal nor perfect. "Such a thing as an absolutely fair tax has never been conceived by the mind of man," Mr. Ballance said, but he offered his tax law as a great advance on what had gone before. There are six special features in the new taxation: Land and incomes, especially those of corporations, are taxed for national purposes.

This taxation is progressive, and heaviest for the richest.

Improvements are exempt.

Small estates and small incomes are not to be taxed.

Mortgages are deducted from the property of the small taxpayers.

Absentees are penalised.

The exemption of improvements, and the exemption of the small men are cardinal features. No landowner with property worth less than $\$ 2500$ clear pays any national tax on his land in New Zealand.

This exemption is planned expressly to favour the small men-"the struggling poor men"-as I heard the Commissioner of Taxes say, and this is avowed by the government in its publications.

Exemption has another purpose-to encourage the rich man to employ labour and improve his estate if he holds it; if not, the progressive tax encourages him to sell. 
"By taxing land," Premier Seddon says, "owners are compelled to take out of the land what there is in it-its fertility, power to support population. 'There it is,' we say, 'take it out.' They have to build houses and fences and to cultivate; to employ smiths, masons, carpenters, and circulate their money."

The new legislation was cautious. Improvements, for instance, were in the first law not wholly exempt, although the popular party were pledged to their complete exemption. Only fifteen thousand dollars' worth of improvements were exempt by the law of I89I. The treasury had to be considered, and it was not until it was found that the revenue would permit it that full exemption was given.

As mortgages are in part on the security of the land, the exemption of the mortgage is an additional exemption from the land-tax. Owners of land worth less than $\$ 25,000$ are allowed to deduct any mortgages they owe from their valuation. To be the owner of property worth more than twenty-five thousand is to be doubly penalised. Such a one has to pay the graduated land-tax, and gets no deduction for his mortgages.

The third exemption is of small properties. That is, after the improvements and the mortgages have been deducted, there is, if there is not more than $\$ 7500$ left, a still further deduction of $\$ 2500$ allowed. This exempt amount decreases gradually when the valuation, less improvements and mortgages, rises above $\$ 7500$ and until $\$ 12,500$ is reached. At that point, $\$ 12,500$, it ceases.

The democracy in New Zealand is a humanitarian taxgatherer. If an old or infirm person owns land or mortgages returning less than $\mathfrak{f} 200, \$ 1000$, a year, and he can show that he is unable to supplement this slender income, and that the payment of the tax would entail hardship, the commissioner may remit the tax. 
The capital invested in the mortgage does not escape taxation, but it is taxed in the hands of the lender, for he must pay tax on his mortgages as if they were land.

The amount deducted for improvements is "the inexhausted value," that is, the value still remaining. Taxpayers' human nature is the same in New Zealand as elsewhere. When the improvements were taxable under the late property tax, no taxpayer could see any value in his improvements to speak of ; but now that what they are worth can be deducted from the property to be taxed, the appreciation which taxpayers show of them excites the wonder of the Commissioner of Taxes.

Improvements are not entirely free from taxation, for the tax on mortgages is of course a tax on improvements as well as on the land. The mortgage tax is also a tax on the borrower, since the lender not only makes the borrowers pay the tax, but makes them pay him a profit for handling it. The Commissioner of Taxes thinks that this adds one half of one per cent. to the rate of interest.

Professor Seligman is certainly right when he says in his "Essays on Taxation" that the exemption of improvements in New Zealand favours the city owner of real estate. The improvements are a much larger proportion of the total value of landed property in the city than in the country. The capitalist who has expensive tenements or warehouses or productive property unencumbered, pays no land-tax on the money invested in the buildings. He pays only on the "prairie value" on his lot.

The taxation of mortgages also favours the unencumbered man and increases the burden of the man who has had to borrow. He who is free of debt is free of taxes on his improvements, but not so the man who owes on a mortgage and on whom the money-lender throws the burden of the tax in higher interest. 
Farm tenants pay no income tax on profits derived from the land. They pay no land-tax, for that is paid by the owner of the land. They feel the tax only in the rent.

As the government is an extensive lender to landowners in advances to settlers, it very properly and shrewdly stipulates that valuations made for lands shall also be valuations for taxation. The citizen's property is not to be considered worth more to borrow on from the government than to pay taxes on.

There was a provision in the law as passed at first, but since lapsed, that the government could take the property of any taxpayer at the valuation he had put upon it, plus ten per cent., if he objected to the figure at which the government proposed to tax it. It was under this provision the Cheviot estate was taken, as we tell later.

The Land and Income Tax Commissioner, Mr. John McGowan, drew up for me the following schedule illustrating how the exemption of improvements, mortgages and small properties operates:

On land worth say............... \$25,000

With improvements of .............. \$10,000

The unimproved value would be......... The land, including improvements is mortgaged for 15,000 The amount taxed................

Where the land is worth . . . . . . . . . . $\$ 35,000$ And the improvements............... I5,000 And the unimproved value is . . . . . . . . \$20,000 And the land and improvements are mortgaged for. 12,500

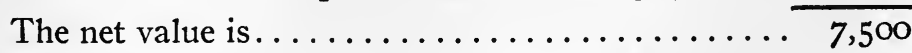
And the exemption............... 2,500

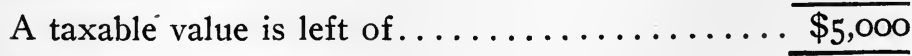
And on this the tax is ............... 
A large number of landowners pay no tax at all. Something like eight thousand to ten thousand of the small farmers out of sixteen thousand have been relieved of taxation by the change from the property tax to the land and income tax and pay nothing. Out of ninety thousand landowners only thirteen thousand pay land-tax.

"The land-tax is expressly planned," the Commissioner of Taxes said, "to exempt the small owner and to free the struggling poor man."

The land-tax begins to be progressive or graduated when the values reach $\$ 25,000$ above improvements. There is no tax on improvements, large or small, but the privilege of exemption of mortgages is withdrawn when estates are large enough to be subject to the graduated tax, that is, at $\$ 25,000$.

The larger owner not only pays a larger rate of tax, but loses all the exemptions, except those for improvements. The extra tax increases by one-eighth of a penny up to a value of $\$$ I, I 50,000, when its maximum is reached of twopence in the pound, or four cents in every $\$ 4.86$. This added to the original tax of one penny in the pound makes a maximum possible tax of threepence, or six cents on $\$ 4.86$ of value, or about .or3. So that the iand-tax even at its heaviest, is not heavy. The purpose was sweeping, but the execution has been most gentle. The taxes are not destructive; great estates still exist. The worst that can be said is that notice has been served on the monopolists that they must surrender or disappear.

Another graduated tax is that on estates which pass by death. Nothing is demanded of properties worth less than $\$ 500$, nor on estates that descend to widows and widowers.

The rate up to properties worth $\$ 5000$ is two and one half per cent. It then rises to three and one half per cent., until a limit of $\$ 25,000$ is reached, when it becomes seven per 
cent. up to $\$ 100,000$. On all estates above that, the rate is ten per cent.

On the passage of the new taxation laws, some of the "sentimental" capitalists undertook to carry out their threat of "leaving the country," to the extent of refusing to lend. They said to borrowers who sought to renew mortgages, "You have elected these labour men, go to them for your money."

The only result was that they lost their business, for there were others with money to lend who were glad to get the securities. The only persons who were punished were the wingless capitalists themselves.

Owners of estates large enough for the graduated tax have a further penalty if absentees : then their graduated tax is increased twenty per cent. The collections under this head are very small. Some of the absentees escape this tax by periodically returning to the colony.

The absentee tax was not an invention of New Zealand. In England two hundred years ago, it was enacted that " $a b-$ sentees are to be assessed a double portion on their lands, stocks and chattels." And even in Ireland, in the reign of Queen Anne, an absentee tax of six shillings in the pound was put on all office holders who did not live half of the year in the country. Times have changed, and in Ireland now the absentees are not taxed-they tax.

The land-tax yields $\$ \mathrm{I}, 075,000$ a year and the graduated tax and the absentee tax add $\$ 450,000$ more.

The income tax is popular because it taxes only the profits of industry, and not the materials or adventures of industry, and because it taxes men on their improvements and experiments only as they are successful and only in proportion to their success.

It is popular with business men for the reason well stated by the Honourable William Pember Reeves. "It is an in- 
surance premium which the business man pays for entire relief from taxation when he is not in a position to pay taxes."

South Australia had preceded New Zealand in its adoption of an income tax, and its success there made it impossible to doubt its practicability.

As planned in New Zealand, the tax is free from unnecessary publicity. The New Zealand income tax follows the same lines of policy as the land-tax. The small man is exempt. The rates increase as the income increases. The man who has an income of only \$I 500 a year pays nothing, and fifteen hundred is deducted, with one exception, from all incomes before the tax is levied.

To encourage thrift life insurance premiums up to $\$ 250$ are also exempt. The rate of the tax is sixpence on the pound, or twelve cents on $\$ 4.86$, up to five thousand a year. On all above that the rate is double, one shilling on the pound.

The exception just spoken of is in regard to companies. Corporations, joint-stock companies, are not allowed the \$1500 exemption, nor are they given a low rate. They must all pay at the rate of a shilling on the pound on all their income.

Absentees, too, are punished as in the case of the landtax, and are not allowed the \$I 500 exemption.

The steamship companies and other owners of vessels doing business in New Zealand ports, though not resident there, must pay income tax on the profits of their business in New Zealand.

The introduction of a new system of taxation is always attended with embarrassments and disappointments; but though there has been embarrassment in this New Zealand experiment, as was inevitable, there has not been disappointment, and the revenues of the country have been increased. 
The income tax yields $\$ 575$,ooo a year. This looks small to the American accustomed to big figures, but everything in this world is comparative. The substitution for the property tax of the income tax and the land-tax, with the exemptions of improvements, mortgages, etc., has not resulted, as it was predicted would be the case, in a disastrous shrinkage of revenue.

In explanation of the small amount received under the income tax, it is to be remembered that no income from land or mortgages or "from the use and produce of land enjoyed by the owner or occupier" is taxable under this head. The land-tax takes care of landed property and mortgages.

When a farmer makes a good thing out of butter or stock of his own production, he is not called upon to pay income tax, and on the same principle, the man who sells cattle out of his own herds does not pay income tax on the profits. But if the same man cuts it up into meat in a town shop, he must pay income tax on that business.

If a man is a dealer in stock which he gets from others, he must pay an income tax on his profits, but if he sells only the cattle raised by himself, he is not liable.

The receipts of the land-tax are steadily decreasing, year by year, though land values are increasing. Of course, since small estates are exempt, and both the government and private owners are cutting up large tracts into smaller pieces, there must be a continual withdrawal of land from taxation.

The farther subdivision is carried, the greater will be the loss of revenue. The tax is evaded, too, I was told, to some extent by dividing property of taxable size among the members of a family into pieces small enough to be exempt.

Some papers, like the "New Zealand Times," recommend that this decrease be met by taxing the small men; but this backward, not to say, revolutionary measure has few friends.

"To increase the graduation," both in the income and the 
land-tax, is the remedy that seems most popular among the radicals. They point out that the colony has sold altogether, for less than $\$ 80,000,000,15,000,000$ acres of land which are now worth $\$ 420,000,000$. And they insist that this difference in value could have been saved by a proper system of taxation and that it is now a proper subject for a heavier levy.

What part had Henry George in the land-tax reforms of New Zealand? Though obviously not a single tax country New Zealand has made so much progress in the direction of taxing land that the influence of that great American at once suggests itself. I found Henry George everywhere spoken of with the greatest admiration. Premier Ballance quoted him as an authority for one of the details of his land-tax scheme, and referred to him as the "greatest authority on the land question, who has revolutionised public opinion." Ballance described as his ideal tax a tax on the value of land, less improvements. "It is our intention gradually to lead up to the pure land-tax."

His government would have been glad to exempt mortgages from taxation, as they understood perfectly well that this was a tax on improvements; but for fiscal reasons they were unable to do so. "Our land-tax," the commissioner said, "is not a pure land-tax, because we feared that would not raise revenue enough. It was impossible to foretell the fiscal result. The mortgage tax was, therefore, made a part of the system and that saved the revenue."

Parliament has passed a law authorising towns to levy their taxes-or rates-on the unimproved value of land, forcing idle property into use, if the people vote to do so. But the public opinion in favour of this "single tax" is so feeble that in the three years the law has been in force, only twenty local bodies, none important, had voted on the proposition. Twelve adopted and eight rejected it. 
From this it is evident there is very little "pure land-tax" enthusiasm among the local taxpayers. As for the national bias in favour of such taxation, it dates back of the apostolate of Henry George to the ministry of Sir George Grey, who, in 1878 , introduced the land-tax into New Zealand finance. Only one collection was made, and in the next year the tax was repealed and the favourite of the monopolists, the property tax, replaced it.

"New Zealand," Sir George Grey said, thirteen years later, "was thus the first country to have a fair land-tax. It was the wonder of other countries at the time."

South Australia adopted this land-tax and has retained it, but allows no exemption. "But it came too early here," Sir George Grey said. "The great landowners trembled. They believed it was putting in the thin edge of the wedge." They rallied all their forces and Sir George Grey was punished by expulsion from office.

"Years of suffering," Sir George Grey said, after this revolt, in I890, "have taught the people how great a boon they then lost, and they are now determined once more to get and keep forever that tax for which almost all mankind from one end of the earth to the other, are now longing."

"Henry George was not in it," the Commissioner of Taxes said emphatically in explaining that the New Zealand tax was born before Henry George's ideas were known, and that the land-tax now in force was not a "pure land-tax."

"Henry George had little influence," another authority declared. "He frightened us by the confiscatory features of his plan."

Mr. Ballance, in a pamphlet in 1887 , said, "Henry George would not pay from the public exchequer for the economic errors of the past, but would make the individuals who accepted the guarantee of the state a victim of the national wrong-doing. To state the doctrine is to condemn it." 
The most important thing about the land and income taxation of New Zealand is its spirit-its purpose-to work to redress the social balance between the too rich and the too poor. But little more, however, has been achieved than to point the way and take the first step.

In the simple statement that New Zealand still raises seventy-five per cent. of her revenue from the tariff, that much the largest part of this customs revenue is derived from the necessaries of life, is made manifest the unpleasant truth that even in New Zealand the people are taxed, not according to their ability to pay, but according to their necessities.

The basis of contribution through the tariff to the support of the government of New Zealand is the amount of tea, kerosene, sugar, etc., which a family must consume, not the amount of wealth which is conserved and increased for it by the state.

The class which gets the chief benefit of the government, and the class which makes the chief contribution to the cost are not the same.

There have been some reductions of the duties on the necessaries of life, but they have not been large enough to affect the general character of the tariff as "the white man's burden."

I found a rising demand among the Progressive Liberals for a change in this policy. With the election of 1899 the Conservative party, which has so fruitlessly attempted to stem the tide of liberalism, has practically disappeared forever. The Liberal party enters upon the task of administration for its fourth inning with a majority of thirty in a Parliament of seventy-four-fifty-two to twenty-two.

Influential papers like the "Times" of Lyttleton are calling upon the ministry to use its overwhelming power to readjust the burdens of taxation by increasing the land and 
income tax and lightening the tariff. They point out that the land and income tax system was adopted for two purposes which have not yet been achieved. First, to break up monopolies, especially that in land; and second, to transfer the main burden of government to those who get its main benefits.

These principles have been given all the dignity of statutory initiation, but they cannot be said to be carried out by a policy which collects three quarters of the taxes by a method which throws the heaviest part of the expense of the state on the poor.

Special protest is made against the policy of spending on public works money raised by this tariff. An average of $\$ 2,000,000$ a year of the general revenue is appropriated to railroads and the like. "These amounts," Mr. Henry George Ell, a young workingman of Christchurch, leader of the Progressive Liberals, and just elected to Parliament, says, "are taken from the masses of the people to be spent on railroads and other works to enhance the wealth of the landowners."

The consideration that is shown small men in the land-tax is undone, much more than undone, in the tariff.

Mr. Ell is going about showing the farmers that they would be much better off if they could exchange the favours of the land-tax for justice in the tariff. If the preferences given the rich by the tariff were abolished, these small farmers would save so much that they could lose all their exemptions, pay the taxes on the full value of the land and still have money left. But by taking out of the poor man's pocket the funds for the public works, railroads and the like, mainly for the benefit of the landowners, the state is constantly abstracting large sums of money from the pockets of the masses which it is spending against their interest to increase their rents and the cost of living. 
The present Premier, the Honourable R. J. Seddon, is in sympathy with the demand for this democratisation of taxation. During the last campaign, in 1899 , he told the Liberals that if he had to choose between the introduction of penny postage and the lowering of the tariff, he would take the latter. Postage reform would cost the revenue three hundred thousand dollars, two thirds of which would go to the people in the cities, and among them, almost wholly, to the business class. He thought it more important that the taxation of the necessaries of life through the tariff should be reduced to the masses. And he declares himself willing to reduce the tariff taxes in exchange for a higher land-tax.

The total revenue from the land and income tax is only $\$ 3,329,340$ a year, while the tariff produces $\$ 10,201,155$. The average rate of the tariff is twenty-five per cent. and the rates on the necessaries of life are much higher than the average. Tea is forty per cent.; sugar, thirty; rice, fortytwo; salt, forty-eight; kerosene, ninety. The largest taxpayers are spirits, tea, sugar, tobacco, kerosene, currants. These are the poor man's necessaries; which means that a man pays taxes according to the size of his family; and the poor man in all countries is the family man.

Mr. Ell is a leader in the agitation for a lower taxation on life and a higher taxation on land. Through newspaper articles, the organisation of the Progressive Liberal Association of Canterbury, and by public speeches and political campaigns, he is waking up the press and the politicians and the people to the fact that there is an issue here which will have to be met.

His association has papered New Zealand with the facts and arguments about the discriminations against the masses inseparable from a tariff on the necessaries of life, and has made a household word of the famous quotation from Pitt:

"To levy a direct tax of seven per cent. is a dangerous ex- 
periment in a free country, and may excite revolt; but there is a method by which you can tax the last rag from the back and the last bite from the mouth without causing a murmur against high taxes, and that is to tax a great many articles of daily use and necessity so indirectly that the people will pay them and not know it. Their grumbling then will be of hard times, but they will not know that the hard times are caused by taxation." 


\section{CHAPTER VII}

\section{A MAN BETTER THAN A SHEEP}

New Zealand, though so young, has tasted of land monopoly to the dregs, and has not liked it. "Earth hunger" became ravenous early in that beautiful and fertile country. It would be idle to tell the old story, told in all countries, of the various and devious ways in which the heritage of the people was legislated away and stolen away in New Zealand. Enough to say that when the people came to themselves in the civic revival of 1890 they found this the chief among the evils demanding remedy. Large areas were held by the few, and they would not sell and would not cultivate. Population surged up against stretches of fertile plain and valley, only to find these kept out of the market to exact a suffocation price when the population became more crowded. They were used meanwhile only for sheep. New Zealanders are fond of sheep, and one of their greatest staples is frozen mutton, but they finally made up their minds to give men the preference.

Sir George Grey, as proud to be a commoner as he had been to be governor, pointed out in his place in Parliament, in 1891 , that $17,937,570$ acres of land were held by only I615 landowners, while I00,000 people occupied less than 300,000 acres. And seven years later, in his "Long White Cloud," the Honourable William Pember Reeves showed that "in spite of land laws, land-tax, and time, out of 34,000,000 acres of land $21,000,000$ are held in areas of more than 5000 acres." 
Sir George Grey asked, "Does it not seem almost incredible that so great a disparity should exist, and that that disparity should have been created by the rulers of this country, the trustees of the public lands which belong to the whole people?"

$\mathrm{He}$ raised a question which has not been answered yeta notable question to have been asked by an aristocrat of aristocrats.

"I doubt," he said, "that all these vast properties have been 'legally' acquired as we are told. If trustees make laws, possibly for their own benefit, can it be said that when their wards are left in such a state of poverty and distress the distribution that has been made of the common property has been 'lawfully' made?"

As early as 1870 this tendency to consolidation had been seen and deplored, and the compulsory resumption of the lands alienated so wastefully, and in many cases worse than wastefully, had been suggested. Sir George Grey was an advocate of resumption, and in 1887 Sir Robert Stout introduced a bill for compulsory repurchase, but nothing effectual was done, and the aggregation of huge estates went on. Some of the ministries tried in various ways to create and keep an independent yeomanry, and other ministries did their best to thwart these efforts.

As one way to prevent concentration lands were sold in small parcels and were leased instead of being sold, but the small men sold out or were sold out. When land was offered in small pieces to perpetuate "the yeomanry," the great companies and the large landowners in the vicinity had their shepherds and cooks and station managers and their workingmen and even their wives buy the land, and then transfer it to them. Owners were allowed a certain amount of land in proportion to the wire fencing they erected, and they ran their fences along the public roads 
and the streams and up the fertile valleys, acquiring long and narrow strips for themselves, rendering all the land behind them useless to other settlers.

The alienation of the land, it must not be forgotten however, was not entirely the fault of the land speculator and the monopolist. In the early days the colony was very glad to sell its land. It was a gala day long remembered in Christchurch when the provincial government of early times was able to announce that it had made a sale of land by which it could reduce the railway bonds by $\mathfrak{1}_{50,000}$. The provinces sold their land to pay off their debts, for land was the only convertible property they had.

The abuses of the four years from 1887 to 189 I made that administration a carnival of land dissipation, and its Minister of Lands was known as "The High Priest of Dummyism."

"The land grabbers picked out the eyes on the plains," a New Zealander explained to me, "and left only the hills and mountains. When the farmers came along they had to ask, 'Shall sheep and cattle occupy the plains, and our wives and children go to the mountains and the hills?" "

Gold diggers and hunters would come back telling of the beautiful land they had seen, which the people could not even look at, for the squatters and land grabbers would not let any one penetrate their fences, and would send their servants to dog any one venturing inside.

The land was mostly in the hands of joint-stock companies and, even worse, absentee corporations. The managers of these companies, all British, of course, were driven by the demands of their stockholders in London for dividends to do things no other landlord in the country would do. They put through the courts a tenant who was behindhand when, if they had been individual owners instead of companies, he would have got time and escaped ruin. 
Minister of Lands McKenzie, in the debate on the land bills which followed the tax bill in the programme of reform, quoted with great effect from a speech of the chairman of one of these great companies to the shareholders in London.

"He said they were going to declare a dividend and bonus of fifteen per cent., but the shareholders could not look for any higher dividends or bonuses until wages had been reduced in New Zealand."

The minister declared that these companies wanted the workingmen of the colony to be "actual slaves," and that their influence was being unitedly thrown against the land reforms he was proposing, because it would enable these poor men to get out of the rut of poverty.

The pressure for land became a political pressure. The issue between "squatters" - as the great land grabbers were called-and settlers, between man and sheep, was one of the crucial issues of the campaign of 1890 .

"No matter what party a candidate belonged to," I was told, "he was sure to be asked at the polls again and again, "What will you do about the land?"

If the New Zealanders had strong democratic ideas about the social control of land, it is easy to see where they got them. Besides the tutoring of experience, they had been taught such views from the beginning by a series of remarkable men. Along with the selfish and often illegal absorption of land there went from the first an active and noble movement in opposition to it.

Foremost among the land democrats was Sir George Grey. By a happy opportunity he was made a builder of the foundations of society in places as far apart as South Australia, New Zealand and South Africa. He did his best to affect with some touches of justice and common sense the policy of the British Empire to its hundreds of 
millions of subject races, and his influence reached even to India. He was able to arrest the policy which first robbed the natives and then created monopoly and aristocracy through the division of the plunder. From first to last Grey was a faithful preacher of "land for the people," even in England and Ireland as well as in the colonies.

Sir Robert Stout, several times Premier and now Chief Justice of New Zealand, the most intellectual and cultivated radical in the Southern hemisphere, and John Ballance, whose name is revered from end to end of New Zealand as the greatest Liberal Premier of the past, always put the democratisation of land first in their programme.

To the financial genius of Sir Julius Vogel it is due that at least half a century was gained in the development of railroads, public works, immigration and land settlement through the investment of British capital in the bonds of New Zealand. The most important part of his public works scheme was that the community should secure the enormous increase in the value of lands which he foresaw must follow. This he was forced to throw overboard by the prejudice and selfishness of the Parliament of the day, but the idea could not be thrown over.

When John Ballance became Premier and John McKenzie Minister of Lands, in I891-a position in which McKenzie has continued with Premier Seddon since the death of Ballance in 1893-the hour and the men to toll the knell of land monopoly in New Zealand arrived.

McKenzie had been a boy in the Highlands. The land-. lord was the head teacher in the hard school in which he learned the political economy of land. When he was pushing his land bills through the New Zealand Parliament he was twitted by members of the Opposition, who sneeringly "wondered where he got his ideas!"

"In the glens of Scotland," he replied. 
"What made me a reformer?" he said in answer to a question from me.

"When I was a little boy, one day going along the country road with my father I saw a lot of people, about thirty families, who had been evicted from Glen Calvie. They were not allowed to stop even in the public highway. There had been but one place opened to them, and we found them in that. There they were, a hundred souls or more, making their fires and cooking their morning meal in the cemetery of Kilcairdin, among the graves. They had slept in the church, and they ate in the shadow of the tombstones, the living among the dead.

"I have seen in the Highlands of Scotland the ground harrowed over during the night in order to hide the blood shed by the people who had been trying to defend their homes."

The minister revisited his boyhood home in 1899, and when he came back he had had another lesson. In a public address upon his return he told how old neighbours had come to him and begged that he would not make any speeches there on the land question, lest the landlord take offence and they suffer. There are "Outlanders," it would seem, nearer home than the Transvaal!

"It was sheer necessity that drove me into politics," he said in describing his early career. "When I came from Rosshire to the Otago district of the South Island we had no schoolhouses, no post-offices, no roads, no bridges-the country was a wilderness. I was the first settler. When others came we united___"

"To demand these improvements of the government?" I interrupted, in Americanese.

"No," he said, in New Zealandese, "to assist each other to get them by the use of our political powers."

He was secretary of the first school board, and the school 
which started with twelve children now has five hundred. $\mathrm{He}$ was the secretary of the road board.

"I made the first road," he said, "in the district, and never put a level on it, for I had none. But," he added with pride, "it has never been altered. I was secretary also for nine years of the old Otago Land Board."

Mr. McKenzie for twenty-nine years has been in public positions of one kind and another in New Zealand, from secretary of the Otago Land Board to member of Parliament and Minister of Lands, and has never been defeated in an election.

"The laws in those days were all made by monopolists. Land squatters and speculators and land grabbers got into the provincial councils and made laws to suit themselves. The people had no voice. A man had to hold a certain area of land before he could get a vote, and the people were represented entirely by one class, and they made the laws to suit themselves. I found the situation so obnoxious that I resigned from the Otago Land Board. It was of no use to go to the meetings, for I could do nothing. These people had picked out all the best pieces of land under laws which they made and administered entirely in their own interests. Our young men and young women were growing up and could find no land to settle on. They were capable enough and had capital, but they had no land. The cry among the farmers was "What shall we do with our boys?' Out of this situation sprang the land laws, and the land and income and inheritance taxes."

The land situation was so bad when Ballance and McKenzie set themselves to find a remedy as to justify the statement made by a member of Parliament that "We have had the most pernicious system of land legislation in this colony that has ever been known in any civilised country in the world. Our land laws were designed by squatters, 
in the interest of squatters, and they have been administered by squatters' nominees for the purposes of land jobbery and monopoly." "Now is the time to get rid of them," said another member in Parliament.

Minister McKenzie had a map made which he hung up before Parliament, showing how the country was blackened with the great holdings. They saw the huge estates and how the land was "gridironed" and "spotted." In the settlement of the colony, the frontages along the roads and rivers, and around watering places, and at the heads of valleys, were all taken up under laws made by the great landowners for the great landowners. All the river flats and gullies and every stream and highway had been picked up. This rendered access to the lands in the rear impossible, and made them useless even with access, since they were cut off from water. Behind these frontages were millions of acres of back country, which were held under lease from the state by the owners of the frontages, and were of no value to anybody but them. The leases were to expire in 1896 , and the colony would have then on its hands these millions of acres which it could sell or let to no one but the owners of the frontages. Unless some way were found of breaking through their cordon, the men who had "spotted" the country would own the country.

A tenantry was arising in New Zealand just like the tenantry at home. As Minister McKenzie showed Parliament in presenting his land bills, there were already in New Zealand more farmers who were tenants than farmers who owned their lands.

The majority of the farmers of New Zealand were passing under the yoke of the mortgage. Fifty-eight per cent. of those who occupied their own land were mortgaged so heavily that their interest was equivalent to a rack rent.

The country was paying enormous sums of money every 
year for interest on the loans that had made the railways, roads, and other public works, and added unearned increment to the lands that had been sold for a mess of pottage; but these lands kept in sheep were sending all their profits to Great Britain.

The proceeds of this beautiful country, the minister told Parliament, are being wasted in riotous living by absentee spendthrifts.

Immigration began to move the wrong way. An exodus from the colony set in, or rather set out. "Many people," said John Ballance to Parliament, "are leaving New Zealand for other shores because they cannot get land here. Unless the big estates are dealt.with, this exodus must continue. There never yet was a country with large estates that continued to prosper."

Whole districts in the colony were being starved for want of land for expansion, and the sons of the country were being forced out. The minister's map showed how the land had been "mopped up" by companies, banks and speculators. "In fifteen years," he told Parliament, if things went on as they were going, "there will not be an acre of land left for settlement in this colony, and the lands will be in the hands of 250,000 people. By that time three out of every four individuals in the colony will be landless. The children of five years and under, now, will have no land to settle upon when they come of age. We have parted with something like 13,000,000 acres of our best agricultural lands, and we have only about 2,000,000 acres suitable for disposal in small areas."

With a country that could support easily ten millions of people-Japan has 50,000,000-New Zealand, with less than 750,000, found itself with a scarcity of land. There was springing up in New Zealand a landlordism nothing better than what has gone before in the old country. $\mathrm{Mr}$. 
McKenzie pointed to places in his own electorate where tenants were paying rents at a rate of two hundred and fifty per cent. on the price given the government for the land-in good seasons just pulling through; in bad seasons, "the usual clearing-out sale," and ruin for them and the tradesmen and the business people dependent upon them.

"The cruelty of the freehold" was a phrase often found on Mr. McKenzie's lips in his speeches in and out of Parliament. He told how freehold gives the right to the owner to turn people out of their homes, to burn the roofs of their dwellings so that they may not return to them, and to leave them starving on the roadside, as he had seen them. It was the freehold which was responsible for the deer forests in Scotland. "The whole country-side in parts of Scotland," he said, "has been depopulated of small settlers, depopulated of the men who fought and won the battles of Great Britain in the past. Who scaled the heights of Alma? Who made the charge of Balaklava? Who relieved Lucknow? Who were in a hundred other fights? Who but the Highland regiments, which were drawn from these very men? Who but themselves, their relations, and their families were driven off the straths and glens to make room for deer forests for noblemen?"

"The history of the Highland evictions-the Sutherland clearings-tells how many thousands of families were broken up by the landlords and the freeholders, and scattered all over the face of the earth-the homes of the many made desolate, so that the few can reign in plenty and wealth."

I once walked through the Glen Tilt, a summer's day, from Braemar to Blair-Athol. The river Tilt runs its current of liquid cairngorms between the velvety hills of a great deer forest, where, by the way, there was to be seen neither deer nor forest. All day long we passed from one 
little homestead to another, but the homesteads consisted only of demolished walls and foundations levelled to the ground, and the only inhabitants were memories. We stopped at a peasant's cottage near the entrance to BlairAthol and the park of the great duke to get a glass of milk.

"Glen Tilt," the farmer's wife told us, "used to send a thousand men to the wars to defend their country, but the people have all been driven away and their homes destroyed to make the deer forests you have been walking through. And," she added, with a gleam in her eye, "they have gone to America, Australia and Canada, and from there they are sending into our markets their cattle and wheat at prices which are drying up the rents of the very lords who banished them."

Naturally Minister McKenzie criticises the new Irish land policy of the British government, by which the government advances money to the peasant to buy the freehold. This will end, he predicts, in mortgaging and consolidation.

Behind the freehold Mr. McKenzie saw gathering in New Zealand all the things he had been taught by the lords of the Highlands to hate-the power to rack-rent, foreclose and evict, to add field to field, to put deer and sheep where men, women and children might be, to speculate and monopolise.

"We have had the freehold for fifty years," the minister said to Parliament, "and the result is these big estates, the greatest curse of New Zealand."

If you chance to overhear the expression "social pests" in New Zealand you will find nine times out of ten that it is the great estates that are the subject of conversation. "Social pests" is New Zealandese for land monopolists.

Another of the current phrases in New Zealand is an expression which flew from the lips of the Minister of Labour, the Honourable William Pember Reeves, author of 
the Compulsory Arbitration law, in a hot debate in Parliament-that it was necessary to "burst up the great estates."

In answer to the threat of the Conservatives that the great land companies would leave the country if the proposed legislation hostile to them were enacted, Premier Ballance said in Parliament:

"We do not care what these huge companies do. We shall not sink even if they all pack up and go."

$\mathrm{He}$ was not warring against capital, he explained, but he meant to restrict the flow of capital to large estates and to stimulate the flow of capital into small estates.

Minister McKenzie told Parliament of a demand for more land made upon him by one of the men into whose maw had been going most of the land which the colony had sold in his vicinity in small parcels to meet the need for small farms.

"He told me that he had already purchased a very large area for cash. He said, 'I want another three thousand acres, or I am going to leave the country.' I told him that I would be very glad to see him leave it."

It was these abuses coming to a head after years of suffering that made the New Zealand people move at last.

As a step toward a remedy, and, as Minister McKenzie said, "only a step," two laws were passed and amended in the years 1892 and following. One of these laws undertook to prevent future monopoly in the public lands; the other to break up by purchase, compulsory, if need be, the monopoly already existing in private lands. Both made ample and particular provision for the resettlement of the people on the land, especially as tenants of the state, instead of private owners. The main idea of both these laws is the same-that land shall be held only for use and for such use only as is for the public good, and that the public is the only judge of what is "good" for it. 
The ultimate ideal of the New Zealand system is that the state shall be the only landowner, the only freeholder; but, with the political sagacity characteristic of their blood, the New Zealanders have not attempted to realise this ideal at one stroke. They took but "one step," but at the same time they understood it to be "but" one step. In the new laws the hated freehold is continued, and yet it is not continued. It is practically discontinued in the disposition of the private estates taken back to be made into farms for the people, but is still given in the sale of public lands.

But new conditions as to use and improvement and area are imposed, which take away from the new freeholds the anarchistic right, beloved of the would-be New Zealand squire as of all squires, "to do what I will with my own," and besides these new restrictions progressing upon him from the rear come the never-resting "progressive" taxes.

No one is now allowed to buy or lease more either of the resumed lands or the public lands than 640 acres of first-class, or 2000 of second-class land, nor more pastoral land than enough for 2000 or 4000 sheep. If he already holds that amount of land he can get no more. Mineral and oil lands are reserved. The government offers its public lands by lease or sale. But it offers the lands it has had to buy, compulsorily or amicably, on lease only. But on those who buy and on those who lease restrictions are imposed to prevent monopoly and insure use-restrictions of area, use, improvements. No one can attain the dignity of state tenant who cannot pass a satisfactory examination showing that he has the money, knowledge and character necessary for success. No one can retain his farm, whether bought or leased, unless he is found to be faithfully complying with all the requirements. Leases can be sold by the tenant, but the new tenant must also satisfy the Land Board of his capability. 
A new tenure is created by the new laws-or rather an old New Zealand tenure, the perpetual lease, is perfectedand special inducements are given to make it more attractive to buyers than absolute ownership. It is called the "lease in perpetuity," and under it the occupier is still the owner, but the owner of a leasehold, not a freehold; owner of the right to occupy, to use, to transmit to his children, to sell, to lease, to mortgage, but not the owner of the right to keep idle, to speculate, or to sell to other speculators. $\mathrm{He}$ is the owner of all the value he puts into the ground, or into improvements above ground, and only under this tenure is he the secure owner of these values, for, even if he forfeits his lease through fault or misfortune, the government guarantees him the value of all his improvements. Only under this tenure also is he free from foreclosure, which is the terror of the freehold landowner. "It is better so we cannot lose it," said a farmer, explaining why he preferred to lease rather than buy.

This lease is especially designed for the poor man, for by it he can get his land without any payment in cash. As the distribution is made among the applicants by lot he has the same chance as the richest or the quickest man in the country to get his six hundred and forty acres of the best land, and he does not have to spend a cent for purchase money. The system is an "open door" to independence for the man who has not money enough both to buy and work a farm, but only enough to work it. He can keep all his money for his farm. The government makes the valuation of the land low, and it charges only four per cent. a year rent for the newly opened public lands, and five per cent. a year for farms cut out of the resumed estates, and this original valuation is never increased, but goes on without change for 999 years.

Minister McKenzie fought hard to have the 999 year 
leases made with thirty years' revaluations, but had to choose between sacrificing this or the whole measure. The increased value gained in the future by the land of the leasehold cannot be reached through the rent, for that is unchangeable for 999 years, but it can be reached through the landtax. Leasehold and freehold alike are taxable on the "prairie value." If the land-tax is increased so as to soak up all the unearned increment of the freehold, it will also soak up all the unearned increment of the leasehold. The advantage sought by the thirty years' revaluation was that it provided for a periodical, automatic increase of the landtax to soak up the increased value.

The tenant has every right the freeholder has, except the right to sell without the consent of the state and the right to keep the land idle.

The New Zealand system is not really the abolition of the freehold. But instead of giving every land occupier a little freehold of his own, which he will probably lose to the money-lenders, New Zealand makes every citizen a joint owner of all the freeholds. Every citizen as a citizen has a freehold in the great estate of the nation.

The demand for the freehold is a demand that the freehold be taken from all to be given to a few. But the policy of leasehold means an inalienable fatherland for all.

There is still a cry for the freehold, especially among the Conservatives, but it is largely the selfish cry of successful men. "Complaints against the leasehold," said the Minister of Lands, "are largely from men who have taken land under leasehold, been successful, and now want the freehold."

"As our farmers get rich," said a prominent member of the Liberal party - "I have known some who have cleared the cost of their farms in two crops-they want to have the freehold in order that they may add field to field, for- 
getting that they themselves are the beneficiaries of the break up of just such large estates, as, in their selfishness, they would now like to found for themselves. It is interesting, too, to note that the Conservatives, the class that habitually decry sentiment as out of place in economic relations, are the loudest in pleading for the freehold on sentimental grounds."

Such pastoral land as there is-and there has not been much as yet in the resumed estates, as they have been selected with a view particularly to farming-is not let on 999 year leases, but for short terms. This permits it to be converted into agricultural use if needed. The right of resuming without compensation is reserved in certain cases, so that the land may be used for closer settlement.

Every year reports are made to Parliament showing in detail every transaction in the purchase and sale of these lands.

Provision is made in the law for garden plots and house and business lots-the latter sometimes under freeholdfor the agricultural labourers, mechanics, and others who would naturally group themselves about the farms cut out of the resumed estates. When employment is scarce, these men can put in their days on their own little places. Leaseholds cannot be mortgaged nor taken for debt, though the improvements may be.

The system of distributing land by ballot has been adopted instead of the former method of auction. This was discontinued because people, in the excitement of bidding, would be tempted to pay more for the land than they could afford, and more than it was really worth. This democracy is a real estate dealer who sees to it that its lands do not sell for too much.

In the same spirit the valuations on which the rents are calculated are made low. The state is a landlord who sees 
its advantage in moderate rents. It says in its official publication, "The state does not so much seek to raise a revenue directly as to encourage the occupation of the lands by the people. This secures indirectly an increased revenue, besides the other advantages which result from a numerous rural population."

Advertisements of land for sale by the large holders are a constant feature of the New Zealand newspapers. One of the ministers told me of a prominent Australian wool merchant, banker and landowner who had just been investigating the New Zealand system of purchasing the large estates for settlement. He was going back to Australia to urge the adoption of a similar system there. He had satisfied himself that the small farmers can make more out of the land than the large holders. The best way, in other words, for the large holders to realise is to sell to small men, and the best way to do that is through the government, which is the most popular seller.

Why the people prefer to deal with the government lies on the surface.

"The land hungerers," I heard the Minister of Lands explain, "started to buy land of the great companies, but when, as often happened, the instalments after the first were not paid, they lost their first payments, all their improvements and their time. They have no such experience when they buy from the state. If they default it resumes after a very indulgent delay, rents again, appraises the value of the improvements, deducts the rent due, and pays back the balance to the outgoing tenant."

The Minister of Lands gives this concise statement of the advantages of the 999 years leasehold, which is being as far as possible substituted for the freehold in the land system of New Zealand:

First. It enables the government to select the occupier. 
Second. It controls the cultivation and improvement.

Third. No transfer can be made without the consent of the state.

Fourth. Speculation and its result-monopoly-are prevented.

Fifth. The area which can be held by any one is limited.

There is absolutely nothing new in this land legislation of New Zealand, neither in principle nor practice, except that the New Zealanders have done whole-heartedly what has been done elsewhere but half-heartedly. Not even the compulsory resumption of the great estates is a novelty. There was a precedent in New Zealand or English history for every step.

Progressive taxation really began when, long ago, small men were made exempt. Limitation of area, stipulations as to use and improvement, are parts of the homestead system of the United States. The perpetual lease had been tried before in New Zealand, but with defects which made it inoperative. Compulsory purchase had been suggested in 1870 , and proposed in a bill to Parliament in 1887.

The compulsory feature was a practical necessity in any reform of the New Zealand land system. Some owners would not sell, some asked extravagant prices, and some, who would have been glad to sell, could not because they were in the hands of the mortgage companies. Some of the owners of the "spotted frontages" that have been described were defiant in their refusal to sell. Behind them lay millions of acres useless to the government or the people unless their frontage could be taken.

Minister McKenzie made good use of the English precedent as to compulsory resumption of the land.

"What are they doing in Great Britain? Does not the state interfere with the land there, although the land does not belong to the state? Have they not appointed royal 
commissioners and sent them down to the Highlands of Scotland to fix the price and regulate other things? Have they not also introduced legislation there to take back the land with a view of putting a class of small owners upon it? Is not that the state interfering with the land? . . . The people of any country have a right to interfere with it."

All civilised countries exercise the power of condemning land when the public good requires. Premier Seddon said, in speaking of this principle in Parliament:

"It is just as important to the colony to take land for settlement as for roads, or railways, or for mining purposes."

Compulsory purchase was at first defeated in Parliament, but Minister McKenzie made the campaign of 1893 on that issue in his district, and was triumphantly returned.

"On every platform during the recess I said that the time had arrived when it was necessary to take land compulsorily for settlement. On every occasion when I said that it was applauded by the people." Seventeen of the twenty-seven members who had opposed this measure in Parliament and had threatened that he should never be allowed to come back were themselves not allowed to return by their constituents. Three times compulsory purchase passed the House of Representatives, but was thrown out by the upper house, but the ministry persisted in demanding it.

"The government is determined," Minister McKenzie told Parliament in I893, "to stand or fall by compulsory purchase."

It finally passed the House of Representatives by a vote of fifty to five, and the upper house then surrendered.

As in the case of compulsory arbitration, here the possibility of compulsion made compulsion itself usually unnecessary. The government has had to resort to condem- 
nation in only two instances, and is offered more estates in all parts of the country than it needs.

An attempt is now being made by one of the great landowners, whose property - the Hatuma estate-is being taken under condemnation proceedings, to break down the law by demanding from the courts compensation not only for the market value of the land, but for the disturbance, sentimental and other, to which he will be subjected. The former chief justice supported his contention, but his place is now filled by Sir Robert Stout, the philosophic radical. The government, on its side, stands for the American rule of damages in such cases, which gives the landowner only the market value. The owner in this case, who is an absentee, is likely to carry the case to the Privy Council of England, but even if he does so, and even if the decision of the Privy Council is in his favour, it will not, I was assured by prominent members of the ministry, have the slightest effect upon the policy of New Zealand in this matter.

The establishment of the claim for sentimental damages would upset the new land system completely. The land which is condemned must, by the terms of the law, be leased to the small farmers at a price which will produce five per cent. revenue on its cost, including surveys, roads, etc. The addition of sentimental damages to the cost would increase the rental beyond the ability of the small farmers to pay. No decision of the courts, therefore, either at home or in England, will avail to arrest the policy of compulsory purchase, for upon that the entire fabric of land reform in New Zealand rests.

This matter was attended to in the session of 1899 by an amendment to the law which provides that when land is taken by compulsion the compensation given the owner shall be only the value of the land and the loss to his business which he incurs from the condemnation. 
This is the rule of damages which has been established by the American railroads, through the courts, for the land they take from the private owner by compulsion. It is also, therefore, the rule of damages which will be applied to the American railroads by the people when they, like the Swiss, take back their highways.

"We must experiment cautiously," Minister McKenzie said, in introducing his land bill of 1892 . Only $£_{50,000}$ a year was asked from Parliament for the first year's purchase of estates. As the experiment felt its way toward success this amount was increased to $£ 250,000$ a year, and later to $\mathfrak{f}_{500,000}$ a year $-\$ 2,500,000$.

Everything connected with this legislation was done in this spirit of "experimenting cautiously." No really new path was opened. All that was done was to move one step farther in the old path of the land reform to which New Zealand had been committed from the earliest years of its colonial life.

The greatest care was taken so to constitute the boards which investigate and recommend the purchase of the resumed estates that they shall be composed of the very best men for the work, and shall be free from jobbery in connection with the landowners, and free from political jobbery.

In resuming land small estates are not taken, and in the case of large estates the owner has the prior right to the lease of his homestead and six hundred and forty acres of first-class land. He has also the right to require that the government shall take the whole of his estate if it takes any. Throughout, it will be seen, the rights of the private owners are strongly safeguarded. As a result there is no social bitterness. There is no cry on the one side for spoliation, no feeling on the other of having been despoiled. The colony is offered more estates than it can buy, and there are but few cases in which the owners will not accept its 
terms. In one of the only two cases in which condemnation has been resorted to, the owners were willing to sell, but the agent, they being absentees, wished, for his own protection and the satisfaction of his clients, that the terms of the sale should be legally fixed by the Compensation Board.

People who have been living on the estates as workmen, shepherds, station keepers, have special privileges in the selection of the land on which they have been living before the estate is thrown open to the general public. The lease in perpetuity is favoured by the government to make itself the only freeholder and convert all the landowners ultimately into state tenants, but it is not forced on the settlers. Recognising that the prejudices, habitudes and preferences of centuries of freehold experience were not to be overcome in a day, the settler in the case of public lands is allowed to choose freehold or leasehold as he wishes. He can buy for cash, or lease with the right of purchase, or lease in perpetuity.

But no such choice is given in the case of the farms cut out of the resumed estates. It would be love's labour lost to break these up and then dispose of them under a tenure which, as all previous experience proves, would start them again travelling the road that leads to consolidation. Some of the very estates repurchased under the new law by the government were years ago sold by it in small sections to favour small farmers. It is willing to recognise in the disposal of the public lands the various preferences of the selectors as to tenure, but it is equally determined never to part again with its ownership of the lands which it is buying back.

Minister McKenzie told Parliament that he proposed the lease in perpetuity largely in answer to the entreaties of settlers who had been foreclosed by the money-lenders, under the freehold system, and had come to him and written 
to him asking for a perpetual lease under which they would be sure of their homes forever.

"Speculation" is a word that Minister McKenzie hates as much as "freehold." It is one of the "cruelties" he charges upon the freehold. He framed the new law for the disposal of the public lands so as "to keep every speculator out of them," he told Parliament. And of his bill for the purchase and subdivision of the estates, he said in the same way:

"No big estates will grow out of the land purchased under this law. It has been rendered impossible. . . . No one has the right to purchase, and therefore there can be no speculation."

Under the lease in perpetuity designed by Minister McKenzie the settlers become tenants of the Crown. There is no middleman, and there can be no transfer without the consent of the government.

"They will soon find that there can be no speculation there," the minister said.

I heard of an encounter between Mr. McKenzie and one of these speculators whom he so much detests.

This speculator had four times got freeholds from the government, and, after holding each of them a short time, sold and pocketed a handsome profit. One day a deputation appeared from the North Island, demanding to be given the freehold of a lot of land its members hold under lease. Though Minister McKenzie had never seen the man just spoken of, he had heard his name, and it was that of the leader of the delegation. Questioning him as to his various places of residence, he soon found that he had before him the speculating settler.

"Now," he said, "you have had four chances at a freehold. You have four times got land for your own home. You have speculated in it and made a good thing out of 
it, but you come here and ask me to help you to do the same thing again. You will never get another freehold as long as I am minister."

"One man one run," was another watchword with which Minister McKenzie called the people to his side. Against the system by which thirteen holders, nine of them companies, could get one hundred and sixty-five sheep runs, one company having twenty-five of them, monopolising all the runs in a district and keeping every one else out of the country, he instituted the system of "one man one run." Under this no one could get more than one run, and that only of a moderate size - a great boon, he said, to our young men, who had been elbowed away hitherto by the dummies of the great monopolies.

It might seem at the first glance that the fact that the state had millions of acres of public lands which it was opening to settlement was a good reason for not buying more land by resuming the great estates. But the public lands were in the North Island, in vast forest wastes, far from roads, markets, or society. It would take a long while to supply this territory with the accessories of trade and intercourse. Land already broken up was wanted for immediate use, and that was already monopolised.

A very desirable class of immigrants, the farmers of England, were entirely unsuited for roughing it in the bush in the North Island, but if they could be supplied with land already cleared, like that of the great estates, they could begin in New Zealand where they left off in England and make a success at once of their new life.

And, then, only by purchasing land could the commonwealth break up the great estates and get rid of the moral, political and economic evils that attend the existence of these "social pests." The subdivision of the land already monopolised was a necessity of New Zealand statesmanship. 
"The more you subdivide the land," Minister McKenzie said, "the more you increase its producing power, and the revenue of the country will be correspondingly increased."

Premier Ballance put the same consideration foremost in his advocacy of the policy of recovering the land and putting the people back on it.

"There is nothing which will conduce more to the prosperity of the country than cutting up those large estates and putting people on the land. Then they will be prosperous, your customs revenue will increase annually, and there will be no more unemployed hanging about the towns. Increase the number of your estates, make easier the position of the producers, and you will multiply the energies of the colony."

A community as highly financed as New Zealand, owing hundreds of millions of dollars in Europe, has need to be sensitive about anything that affects the taxpaying power of the people.

What have been the results?

Up to the end of the fiscal year terminating March $3 \mathrm{I}$, 1899, the government had expended in the resumption of private estates $\$ 6,253,235$, and had added to this $\$ 269,3$ Io for surveys, roads and other costs of opening them for settlement-a total of $\$ 6,522,545$. This is a sum as much for New Zealand as $\$ 600,000,000$ would be for the United States. For this sum sixty-two estates have been acquired, with an area of 256,829 acres. Of these, 218,485 acres had been let March 31, I899, in I304 holdings.

There are now living on this land, instead of the sheep and shepherds who were once their principal occupiers, 3077 persons, and they have built 813 houses. The value of the improvements which have been made is $\$ 645,655$. The yearly cost of this investment of the colony in the interest it is paying on the bonds issued for the purchase is 
$\$ 2 \mathrm{I} 2,438$, while the actual rental is already $\$ 288,735$, and some of the lands are still unlet.

The colony gets the money to buy by borrowing in London at three and one fourth per cent. and less, and it leases the land to the tenant at five. At the date of the report, March 3I, I899, the total income was at the rate of 4.8 per cent., and enough of the land then unlet has since been disposed of to bring the return up to over five per cent. on the capital "sunk." And besides this direct profit is to be counted the indirect-vastly more important.

The New Zealander uses his national credit to get money in London to lend again in advances to settlers and free the farmer from the high rates of interest he is paying the private bankers, and in precisely the same way the New Zealander gets money in London to buy, either with or without the owner's consent, the great sheep runs, to sell them at cost to men who will raise food and families for their own and the common good.

The number of forfeitures has been very small, and most of the forfeited sections have been relet.

The land report for 1899 shows that the total number of Crown tenants is now 15,899 , holding $14,818,557$ acres, and paying $\$ 1,331,765$ a year rent, and of this only $\$ 84,965$ is in arrears.

Mr. Gladstone was quoted during the debate on the New Zealand land bills as an authority against the ability of the state to play the rôle of landlord. After giving his opinion that nationalisation without compensation would be robbery, he said, "Nationalisation of the land, with compensation, so far as I can understand it, would be folly, because the state is not qualified to exercise the functions of a landlord. The state could not become the landlord; it would overburden and break down the state." The people of New Zealand were not deterred by this formidable quotation. 
They went on and made the state a landlord, with results so far quite the opposite of these predictions.

Land in New Zealand is being distributed, not concentrated. The number of small holdings shows a steady increase, though not yet a rapid increase. In 1895 the number of holdings had been 46,676 . In 1899 there were 62,639 holdings of one acre and upward, an increase of 1880 for the year. Out of 62,639 holdings, 36,932-fifty-nine per cent.-were less than 100 acres. Only 10,959 , or $171 / 2$ per cent., hold over 320 acres, and this, it must be remembered, includes a large number of extensive tracts held under pastoral leases.

In 1868 the land was held by only five per cent. of the people. In 1888 the percentage of land holders to population was only one half per cent. better than it had been twenty years before. To-day, notwithstanding the growth of population and of industrial pursuits, two per cent. more of the population owns land than in 1888 .

A picturesque translation of these statistics I found in a letter in the "Lyttleton Times," contributed by "John in the Bush."

"The dear old feudal system of New Zealand is gonebroken up by a ruthless democracy.

"I have stood on the top of the Blue Mountains of Otago and scanned ten mighty baronies, from ten to one hundred thousand acres each, the lord of which had power of 'pot and gallows' in those days. If any man was ever suspected of a longing for an acre of that land he had to go and get his teeth pulled out, as he had no more use for them in that little town by the mountain-side-a town of retired sheep inspectors and others who braved the ire of these potentates and were reduced to sucking wild pigs.

"The scene is changed! Climb that mountain now and 
look around. In place of the wide, rolling waste of brown tussock you see cultivated fields, homesteads, schools, churches and villages, and roads and railways winding everywhere. Ay, and even buggies on the roads, with the gay ribbons of the settlers' pretty daughters fluttering in the breeze. That plain is now a scene of life and bustle, with its pleasures and its pains, and all that goes to make up a healthy, a happy and a free humanity. It was worth a fight for, and King Demos has won-and the barons, the barons, where are they? One is left-only one-and he still hangs grimly on to his one hundred thousand acres of it, and still marshals his squires and his villeins and his serfs, and feeds them on black tea and damper and scraggy mutton, as of yore."

One of the issues put to the fore by the opposition in the recent election of 1899 was the substitution of the freehold for the leasehold. The Opposition promised the people that, if elected, it would allow them to convert their state leaseholds into freeholds, but evidently the people did not want the privilege, for they returned the Seddon party to power with a larger majority in Parliament than before. "The end of the freehold system," Premier Seddon told the voters, "is that the mortgagee gets the farm, and the farmers get the road. If we repeal the leasehold law we will prevent the poor man from getting any land."

Considering that the lease. in perpetuity is a new proposition, and that it has to compete with prepossessions centuries old in favour of absolute ownership, the leasehold is gaining public favour with surprising rapidity. It has happened that lands offered with the right of purchase have remained unsold, but when offered again under leasehold have been applied for several times over. Private estates offered in freehold have gone begging for purchasers, while at the 
same time public land near by was eagerly taken under leasehold.

"The state as a landlord," Premier Seddon has said, "will be more liberal than the money-lenders who foreclose." The state is the unique sort of landlord that reduces rent when it finds itself making a profit. In his budget speech in 1899 the Premier announced that out of its gains the state was able to lower its rents, as well as its interest on advances to settlers, one half per cent. a year, or one tenth.

In a speech on the eve of the election of 1899 , the Premier said that there had not been a single penny of loss on the lands bought, and the rents paid gave five per cent. He promised that the ministry "would borrow more money, buy more land, and put their sons and daughters on it."

Still more radical ideas and plans are fermenting in the New Zealand mind.

The Minister of Lands has declared in a public speech that he "would like to see the time when all the lands of New Zealand were nationalised."

And Mr. William Rolleston, the most authoritative figure of the Conservatives, certainly as regards land questions, said during the last campaign, "We shall never have national prosperity in New Zealand until we nationalise every foot of its land."

Minister McKenzie and those working with him in these reforms saw that the sale of land simply meant, as the New Zealand statistics proved, the concentration of it sooner or later, and probably sooner, in the hands of a few men. When the Crown sold the freehold, it surrendered control and could neither prevent consolidation, nor insist on use. The consolidation of the land then was inevitable; the only choice was, under whom? Should the people become a tenantry under the money-lenders, or a tenantry under the state? What was needed was an owner who would not do 
the cruel and uneconomic things which the private owner did, and this owner Ballance, Stout, McKenzie, Seddon, and their party see in the state.

Both in the land and fiscal policy of New Zealand, since I89I, this has been the ruling purpose-to put an end to "private ownership" of land in the old sense and with the old immunity from social control, and to replace it by a "private ownership" of the tenant under the state with social control for social advantage. The New Zealanders are well on the way to the realisation of what no people have yet had-an inalienable fatherland.

The example of New Zealand has been followed by several other colonies. Queensland, South Australia, and West Australia have each an act for the resumption of private arable lands, and the Victorian Parliament has recently passed a similar measure, but no results of much interest have been achieved in these colonies.

A bill for the resumption of private lands was introduced into the New South Wales Parliament in 1896, but was defeated through the opposition largely of the labour members. It was said by them that the banks and mortgage companies and impecunious or designing landowners "would unload" upon the state, and that the state might again sell the land which it had just bought, and so in a few years have the same curse of land penury and be asked again to practise the same remedy, and thus buying to resell and selling to rebuy commit the endless folly of legislating in a circle.

Perhaps no episode in Australasian history more vividly presents the fundamental difference between Australian character and politics and New Zealand character and politics than this success in New Zealand and failure in New South Wales.

I met a man from Savannah, Georgia, on the train be- 
tween Napierville and Woodville, New Zealand, who had been thirty-four years in the country. He was warm in his praises of his adopted home, but the legislation, especially the land legislation, "was rotten." $\mathrm{He}$ talked on, and in a few minutes revealed the reason for his "conservatism." $\mathrm{He}$ had done his best business, he said, until late years, "in little spec's in land, but the new laws had killed it dead."

One of the leading officials in the Land Department, whose special work is in the purchase of the resumed estates, said to me:

"We have the choice of all the large estates of New Zealand. All are at the call of the government. No man now dreams of buying a large estate or seeking to build one up to leave to his family. All that is a thing of the past. For several years no large estate has been sold in its entirety in Canterbury, and as for speculation, that, too, is a thing of the past"-that is, speculation in farming land. In the cities dealings in "corner lots" are still popular.

Freeholds are still granted in New Zealand, if the purchaser of public land so elects; large amounts of land are still held in freehold, but the determination of the people as expressed in their present policy is to end it as soon as possible. It is for this that they are buying back the large estates, increasing the rate of taxation the landlord pays as the number of his acres increase, taking a larger share of the larger inheritances. It will require long years for this policy to reach its consummation, but it is moving surely, if slowly, toward this goal. In consequence of the laws we have referred to and public opinion, speculation in land in New Zealand is dead, and this is the beginning of the end. 


\section{CHAPTER VIII}

\section{"LANDLESS MEN HAVE THE PREFERENCE"}

There is a place in New Zealand which is the constant resort of a steady stream of visitors, who are sometimes land ministers from other colonies, or economists from the Musée Social of Paris, or other varieties of the "Democratic Traveller." It is the Cheviot estate-the first that was "resumed" and cut up into small farms by Minister McKenzie. I spent two days there in the height of the New Zealand summer, just after the wheat had been harvested. There could be nowhere a fairer sight of level fields, yellow with stacks of grain like huge, golden beehives, and rolling hills ribboned with vivid green stretches of turnip fields in which the sheep were soon to be fattening. Along the west ran the Lowry Peaks, to the east is the Pacific Ocean where the estate had a harbour of its own-Port Robinson. Rivers bound it on the south and north, and streams run through it everywhere. In the centre is the village named McKenzie after the Minister of Lands. It is only five years old, and has hotels, blacksmith shops, stores, churches, schools and houses, large and small, arranged along the wide streets or scattered over the farms and garden plots.

On a commanding position, in the middle of a noble park, is the manor-house of the late owner, still the property of his family, as, in accordance with the considerate procedure of the government, they were allowed to acquire it with five thousand acres of land when the estate was resumed. Sur- 
rounding the village in every direction the eye saw farms with comfortable buildings, well-stocked and cultivated.

These twelve square miles, now teeming with people and prosperity were, until 1892 , the home of but one family with its flocks and shepherds. One man owned as far as he could look, from the mountains to the sea, and from river to river, and there was but one house, for the cottages of the workmen hardly deserved that name. One could travel miles and miles without seeing human beings or a habitation.

It was a lucky accident that gave Minister McKenzie the opportunity to make this demonstration of what "closer settlement" meant. While he was fighting his land bills through Parliament, a dispute arose between the Tax Commissioner and the trustees of this beautiful estate-whose owner had recently died-as to the valuation on .which it was to be taxed. Its 84,000 acres were assessed at $\$ 1,524,630$, a pretty good price for land for which the owner had paid five shillings an acre in 1853 and subsequently. The trustees insisted that it should be taxed for no more than \$I,30I,IO0. There were very few estates in the colony that were the equal of this. The founder of the estate, "Ready Money" Robinson, as he was significantly called, had made very extensive and thorough improvements - good buildings, gardens and orchards, magnificent plantations of pine and a great deal of fencing, a very important item in New Zealand. Under the land and income tax law as it then stood in New Zealand, in the case of such a disagreement as to the assessment, the government had the power to take the property at the owner's valuation plus ten per cent. The land law which Minister McKenzie got through Parliament the same year appropriated only $\$ 250,000$ for the purcliase of estates, but here was a chance to try his experiment on land costing six times as much, and he eagerly took advantage of it. The property was taken 


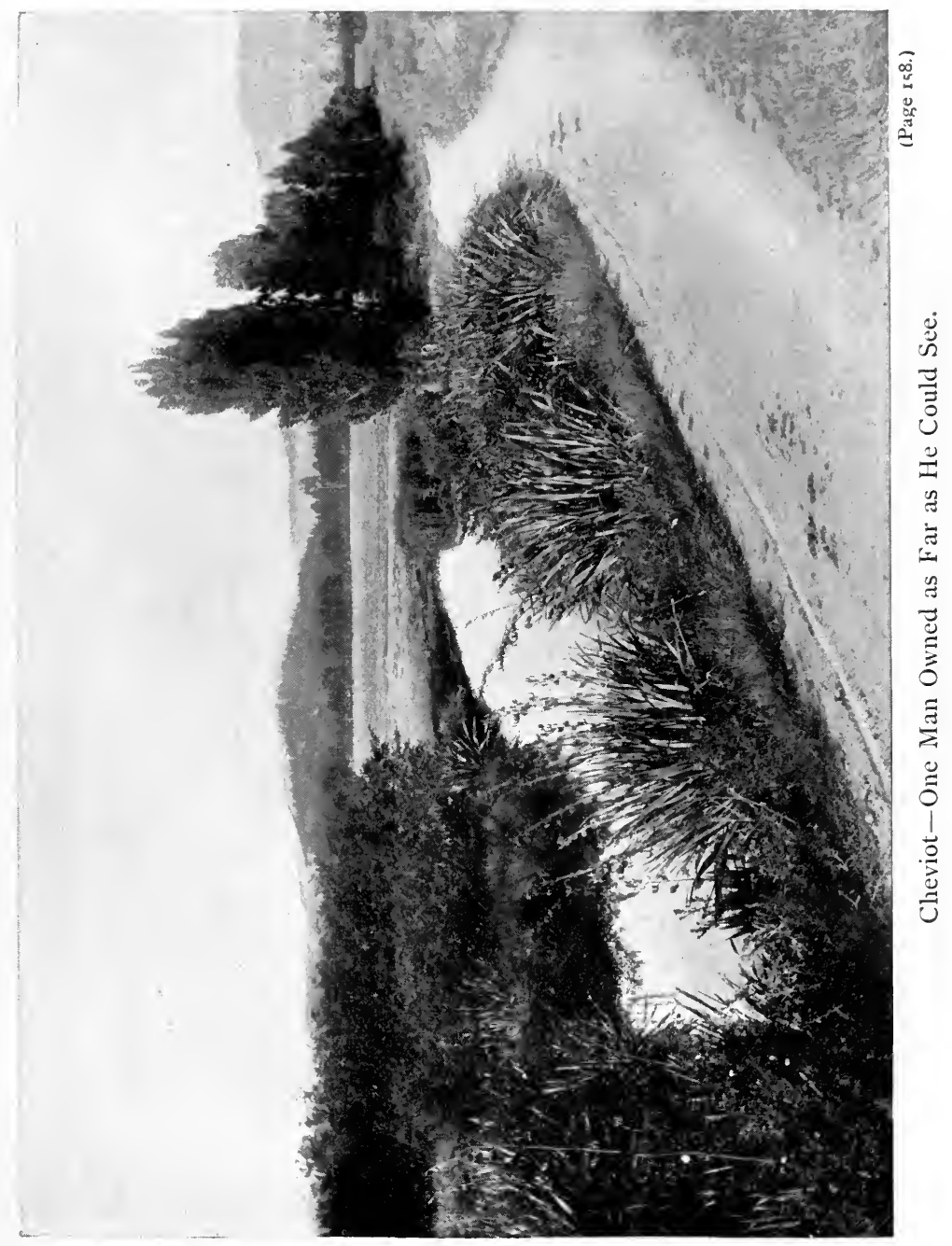



at the owners' valuation-to their entire satisfaction, as they, daughters of the original owner, wanted the inheritance divided.

The Minister of Lands went to work to make his disposal of Cheviot an object lesson. The purchase was made profitable at once. As soon as the department received the title, it leased the land, agricultural and all, for grazing for the summer while it was preparing the estate for subdivision. By this means a revenue of three and two-fifths per cent. on the purchase money was obtained immediately, to the confusion of those who had declared that no government could do business successfully in land. The estate was then resurveyed into agricultural farms of from 50 to 100 acres, grazing farms of from 500 to 3000 acres, one chief township and three villages. Thirty thousand acres were devoted to these farms. Two thousand acres in the vicinity of the town site at the centre were cut up into suburban lots and garden plots. The plan of the new community provided for large men and small men, men with capital and men without. There were farms for agriculturists with money, lots for labourers, and the farmers and the labourers were settled side by side for mutual advantage.

The future was looked out for by leaving areas at all junctions and key points where village sites were likely to be needed in the future.

A railway line was also surveyed through the estate. It was laid off thus early in order that the colony might not have to buy the land back when the time came in the future for the construction of the road.

One of the benefits of the opening of lands to settlement is that it gives the country roads. The great owners refused to make roads; they preferred to close up their estates all around. At Cheviot roads were now made wherever needed, using the gravel which was found in many 
places on the property. A passable road was made to each section offered for sale. Cheviot has a port of its own, and to this port a new road was made at great expense through a bluff of rock, the drive along which vies in beauty with the celebrated road between Sorrento and Amalfi. All this work on the resurvey and improvement of the estate, including the port, cost $\$ 320,000$ in addition to the purchase money.

The Cheviot settlement was an immediate success. It was not until November, I893, that the actual transfer of land began, and in six months, as the Minister told Parliament, one hundred and seventy-one settlers had come in and were living on their property, and more were coming in every day. These settlers had one hundred and ninetyone children with them. They employed twenty other people; there were ten persons in business who employed forty others; there were one hundred and sixty-three labourers working-co-operatively, as is the New Zealand way-in making roads and doing the other work of getting the land ready for settlement. The hammer sounded all day long on the new houses that were being built. In six months five hundred and sixty-nine people had been provided there with land or work. Many of these people for whom a place had been found at Cheviot, the minister said, would "otherwise be among the unemployed in Christchurch, for whom the government would have to find something to do, or they would have to leave the country."

Just the class of men for whom the "one man one run" policy had been adopted came in here to take advantage of it -young men with some capital, $\$ 2500$ to $\$ 3000$ or more, who had been unable to get land as long as it was monopolised by the great companies. As the unpretentious character of the houses shows, they did not spend their money on expensive building, but kept it to put into the best of 
fencing and live stock, which would bring them in an immediate income.

The money spent for the improvement of the estate helped to market it and to provide the very best kind of population to live on it.

In the first year, out of the money they saved more than half the labourers brought in to make roads, build bridges, etc., acquired small holdings out of those specially provided for their class, put up houses and brought in their families. Where the bullock bell used to be the only sound in the old days, there was now to be heard the school bell, and instead of the sheep of old hanging on to tussocks of grass, were now to be seen the children trooping along the road on their way to school.

The experience of New Zealand does not sustain the idea so widely prevalent that city people and artisans cannot make a living on the land. Some of the most successful settlers have been men brought up as tailors or shoemakers, and workers in other trades in the city of London. Sailors and day labourers have been successful, too.

The population of Cheviot which, in 1892, consisted of only one family with their attendants, had increased, in I898, to over one thousand, and is still larger at the present time. The farms have been eagerly taken up and the rents were, on March 3I, I898, paying five and one half per cent. on the net cost. This then stood at $\$ 1,312,145$. The interest was $\$ 44,33^{\circ}$ a year, and the annual rents were $\$ 72,500$. The amount of improvements required of the tenants by law was $\$ 84,160$, but the actual value at the time of the last inspection was $\$ 247,690$. Out of a total rent roll of $\$ 67,575$ a year from 236 leases, there were only 19 settlers in arrears, with rents to the amount of $\$ 859$. There were 4019 acres in grain; 7374 in green and root crops, and II,430 in English grasses. There have been no forfeitures or surrenders. 
In going about this place, I took special pains to find out what causes of dissatisfaction, if any, there might be, and what the shortcomings were, for the temptation to become enthusiastic was almost overpowering. There were some complaints from the labourers who had settled on the small plots. There was not as much work as they had hoped for from neighbouring farmers, and some of them had to go away from home to get it, sometimes for six months at a time. I found the labourers more fortunate at Momona, near Dunedin, where are fourteen settlers on three hundred acres, almost all of them farm labourers. They are surrounded by farmers and have plenty of work. Their wives take care of the cows and the milk for the creamery, while the men are away harvesting.

We met a Scotch family on the Cheviot road, a wagon full of children and furniture, bound for "home," returning to Scotland because the farmer thought he could do better there where his father was. But, as he had sold his leasehold for a handsome advance, before he had even ploughed it, or made any improvements of much value, he could hardly be said to have not done well here.

I found that there had been some little speculation in the properties at Cheviot notwithstanding the great pains taken by the Minister to prevent it. Of course this was but a bagatelle in comparison with the speculation that would have taken place in a settlement under private auspices. To check this speculation as much as possible the Minister has so far refused to allow settlers to acquire adjoining sections. He has established this rule in order to make impossible any such consolidation of properties as it is his whole mission to prevent. He cannot, of course, prevent settlers from selling their leaseholds to incoming tenants nor would he wish to reject the incoming tenants if they were eligible.

The administration is criticised because the work on the 
roads was done by hand and had required the presence of hundreds of labourers, whereas it could have been done at a much less cost and with a small number of men, if done by machinery. It was this, I was told, which had swelled the cost of making the roads to the high figure of $\$ 320,000$. The government, however, could easily see a long profit to itself in the employment of this large number of men. It converted many of them into permanent settlers, producing wealth and paying taxes.

A thrifty young farmer, who occupied one of the most flourishing places in the settlement, stretching along a valley, and just out from under the shadow of the mountains, told me that many men at Cheviot were eking out a bare existence. This was because the land was cut up into pieces too small to enable the farmer to make a living. There are men who get along only by violating the rules as to cropping the land. The complaint was almost universal, I found, not only at Cheviot, but in other similar settlements, that the sections were too small. The ten-acre sections were of little use unless near a large settlement, and not then unless outside employment was certain. Two-hundred-acre sections were of no use to men who wanted to raise sheep, and were no more than a living to the ordinary farmer in New Zealand where there are so few cities, and where so much of the produce has to be sold for export at rates fixed by international competition. This mistake of too small sections was due to a natural eagerness to find homes for the largest possible number of people. In later sub-divisions the farms are made larger.

However I found no lack of opinion among the wiser farmers that what was wanted was not so much more land as better culture. More farmers lose money by having too much land than by giving the land they have too much attention. 


\section{LANDLESS MEN HAVE PREFERENCE}

A now prosperous farmer, who was for years employed on the estate before its resumption as one of the labourers, told me of an interview which took place one day between him and the late owner, who was going over his estate with a party of friends. Meeting his man, he said to him, "Bruce, would you not like to have a piece of this land?" "Yes, sir, indeed I would, sir," the man replied. "Well, that is all you will ever get of it, Bruce," his master replied, and they all laughed and went on their way. Bruce now holds from the government, under leasehold, as fine a farm as there is in New Zealand, on the very spot where he held this conversation with his employer. Last year he threshed out an average of 70 bushels of wheat an acre, and the year/before 68 bushels, and 30 acres averaged 80 bushels to the acre. His farm is 190 acres. With land like that, it is no wonder that Bruce told me, almost plaintively, that he wanted "more land."

The average yield of wheat last year on the Cheviot estate was 45 bushels; of oats 35 bushels, an average of less than the year before on account of the damage done by the caterpillars, and II $1 / 2$ acres produced IOI 2 bushels of barley. The Cheviot settlers have an association, and at their dinner in June, I899, it was stated that one settler was feeding 1400 sheep on 200 acres, and he had also threshed 5000 bushels of grain.

A member of the Land Board told of land in the Canterbury District for which $\$ 200$ an acre had been paid thirty years ago, which is still producing 60 bushels of wheat to the acre in rotation with barley, potatoes, oats, and other crops, with little fertilising except for the turnip crop. The soil is a lime wash three or four feet deep brought down from the mountains.

This fertility of the land in New Zealand is one reason for the high price which it brings. Democracy is another 
reason. There is no cheap land in New Zealand. Land is more productive and is in more demand where the number of landowners is increasing and where the opportunity to get land belongs to the people than under the régime of large estates. The people can always pay more for land than the plutocracy, if they have the opportunity.

But even the critics of the minor mistakes made by the administration in the disposal of this estate had to admit the success of it on a broad view.

"Any one at Cheviot," said one of the grumblers, "wishing to sell and advertising, would get a dozen answers immediately. Cheviot has a great name."

And another pointed out that Cheviot, at the present rate, will have paid for itself in twenty years. "Since it is so profitable an operation, why should the government let the great number of people who want land go hungry for it? Let it buy more and give everybody enough."

Those who are living in the town are doing well. The blacksmith's hearty wife came to the door to answer our questions, and we looked with admiration upon her redcheeked daughter who was driving in the cow at the gate. They had a five-acre piece and a ten-acre piece and a thirtyfive-acre piece. They had got five acres at auction which, had they not secured it, the lady said, would have been used "only for the church," which had also been a bidder.

Along the drive to Port Robinson the workmen of the port have places of thirty to forty acres with cottages bordering on the cliffs hundreds of feet high, looking out over the Pacific and its rugged and picturesque coast. Gardens under the lee of the bank look out to the ocean with sloping sides covered with fruit trees and with flats luxuriant with vegetables and flowers.

The greater productiveness of the close settlement over the great estate is easily seen at Cheviot. The last shipment 
of wool for the late owner, "Ready Money" Robinson, was 2500 bales worth ten pounds a bale, or \$125,000. In the year I 898 , the shipment was over 3000 bales, in addition to which nearly 4000 sacks of wheat were shipped, and a large amount of other products. Over 25,000 fat lambs had been sent away to freezing works, and 20,000 fat sheep exported. This says nothing of the fact that the estate has, in addition to this, been maintaining its population of over Iooo. More important than the lambs that go to the freezing works are the "kiddies," who will live and if need be die for New Zealand.

One of the officials of the Land Department, an expert valuer, told me that he had made a careful calculation of the old Cheviot and the new, and had compared the new Cheviot with some of the large private estates that still exist in the vicinity, and found that this land under small ownership and agricultural use, instead of large ownership and pastoral use, had gained in productive power fourteen times. The money orders issued at Cheviot have increased from $\$ 1630$ in 1891 to $\$ 34,820$ in 1899 .

A man who acts as guide to the wonders of the geysers and hot pools of Wairakei, raises strawberries and lettuce every month of the year in the earth kept hot by a system of steam-pipes supplied by nature herself. He has three hundred acres of government land. "It gives me a chance," was his laconic summary of the land system of his country.

Not far from Cheviot is an estate which has a different story to tell. Its owner some years ago undertook to sell off his land. He advertised widely. The soil is fine, and the attendance at the auction was large. The result shows one reason why people in New Zealand prefer to deal with the democracy instead of the private speculator. The estate was divided into town lots and farms surrounding 
them. The lots were put up first. After the town lots were sold off, the owner stopped the sale of the agricultural lands because he thought it was not bringing in enough. The buyers of the town lots had bid good prices because they calculated that there would be a large population settled on the farms round about. The discontinuance of the sale of the farms left these purchasers high and dry. Many of them were ruined and unable to make the second and third payments, and the land went back into the hands of the owner.

When Cheviot was first offered to the public, some of the farms were put up to be sold for cash in fee simple. No one wanted them. They remained unsold at a considerable loss. Finally the Land Department changed the conditions and offered them under leasehold in perpetuity, and they were immediately "rushed" by a very much larger number of applicants than there were farms. The leaseholder can keep his capital to use in his farming. He cannot be foreclosed if he borrows money, and if he leaves or is unable to pay his loan he is certain to secure the full value of his improvements. The leaseholder cannot borrow on the security of his lease, either from a private banker or from the government. Neither can he borrow ordinarily from a private lender on the security of his improvements, but the Treasury, through the Advances to Settlers office, will make loans on such security. It considers a man's good-will and his improvements good loanable security, and stands ready to lend him money that he needs and knows how to use.

The colony of Victoria last year sent the Honourable R. W. Best, Minister of Lands, and W. A. Trenwith, Member of the Legislative Assembly, to New Zealand to study its land and labour institutions and this is what they say of Cheviot in their official report: 


\section{I68 LANDLESS MEN HAVE PREFERENCE}

"While proceeding through the estate we saw a number of neat homesteads on agricultural and grazing farms, and everywhere there were signs of comfort and prosperity. - . We were much struck with the comfortable and neat appearance of the homesteads. . . . Most of the settlers seemed to be doing well. They paid their threshing-machine bills generally cash down. A request to hold over until the sale of the crop was an exception. . . Whereas the crops under the contract system, when the land was cultivated in its unimproved state, yielded only some sixteen to nineteen bushels per acre, this year the yields have been from forty to sixty bushels.

"We thus completed our inspection of an estate which six years ago was nothing short of a great sheep walk owned by one man, who at most employed but the ordinary station hands, but which now, studded with comfortable homesteads, townships, schools, well-fenced and well-cultivated farms, supports a population of upward of 1200 persons. What has been here effected by the government of New Zealand, receiving interest at the rate of five and one half per cent. on its outlay in the resumption and settlement of an estate, is very reassuring to those who favour any well-contrived system of closer settlement."

While Minister McKenzie was proving at Cheviot what could be done with "closer" settlement, Parliament passed the law he had asked for, to authorise the purchase of land. He has ever since 1892 been buying estates and cutting them up into smaller places along the lines which have becn so successful at Cheviot. Sometimes he acts upon petition, oftener, on his own motion.

If the people of any neighbourhood find themselves crowled for land, they may petition the ministry "to resume" some estate near by. The people of Ashburton, for 


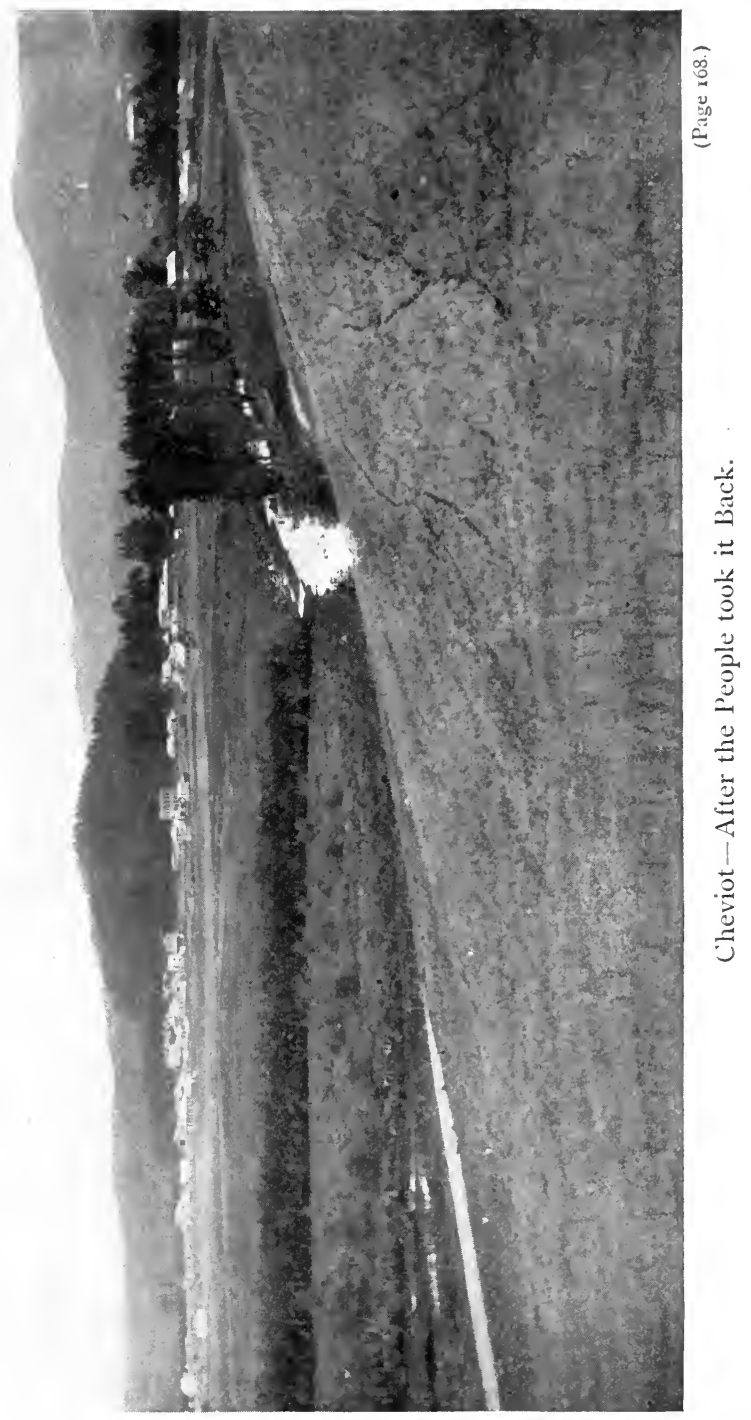



instance, needing land and unable to buy any in small plots from the men around them, sent in the following:

“Ashburton, March I, I895.

"The Honourable John McKenzie,

Minister of Lands,

Wellington.

"We, the undersigned electors in the Ashburton District, do hereby urgently request you in terms of the powers conferred upon you by the Land Act, to set apart a portion of land near Ashburton for settlement.

"And your petitioners will ever pray, etc."

At about the same time this petition was presented-the coincidence may not have been accidental-the "High Bank" estate, about I0,000 acres in the neighbourhood of Ashburton, was offered by the owner. It was inspected by the Board of Land Purchase Commissioners. They found it to be all level land, of fine quality, and only three miles by good roads from several railway stations, and recommended the purchase. Their recommendation was adopted, and the price offered was accepted by the owner. The estate was subdivided into forty-three farms of 50 to 639 acres each, and thirty-nine smaller pieces for village settlements of from one to ten acres each. The farms were all applied for the first day they were offered, and also some of the smaller sections.

There is now a thriving settlement of farmers growing grain, green crops and fattening sheep and cattle where formerly only one man was in occupation, who used the land chiefly for sheep.

The officials of the Land Department do not take these petitions too seriously. Any one will sign a petition. The publicans often promote petitions. They want the land 


\section{I70 LANDLESS MEN HAVE PREFERENCE}

settled to increase the number of their customers. It is noticed that the men who sign the petitions are not usually the men who get the lands. The petitions are frequent, and as one of the Land Department men remarked, "They are usually presented in connection with estates that are offered. The owner sees to it that the petition is circulated. But, as in this Ashburton case, the petitions may represent a genuine demand and a real need, and then, as here, they receive the attention they deserve."

Owners of large estates generally have come to be glad to sell to the government. It is better for them to sell to it than to subdivide themselves, because the people would rather buy of the government. From it they can get debentures which yield $4 \frac{1}{2}$ per cent. on the value of the farm, and this is more than they can make by running the estate themselves.

The large trust companies hold many estates and they want to realise. Then owners sell because they are afraid of the graduated tax. Some of them are getting old and can manage money more easily than property, and the heirs often have the same preference.

One of the finest places I visited in New Zealand was the estate of Elderslie, a few miles from Oamaru. A large part of it has recently been purchased for "closer settlement." On our way thither we went through the Teanaraki settlement of small farmers and workingmen. In a canvas hut a former roustabout was living on ten acres of land and doing well.

"I used to have to get work where I could and to live as best I might. Now I can keep a hack in the paddock, come and go when I like, and get the highest wages. The rent is high, but there is enough in that field to pay it."

We passed from the canvas hut and the hardly more pretentious cottages of the other settlers to a beautiful mansion 
in a park adorned with trees brought from all parts of the world-cedars from Lebanon, firs from Colorado, even pines from India. The estate stretches fifteen miles back of the house.

The proprietor of this private barony retired from business with a fortune at the age of forty, bought a part of this property from the Bank of New Zealand, added to it, piece by piece, until finally he had many thousands of acres. He was in debt $\$ 350,000$, which he had borrowed for improvements. By selling II,O0O acres to the government at $\$ 32.50$ an acre, he has extinguished his debt. He keeps his homestead surrounded by gardens as beautiful as any you will see in the heart of France. His sons also have handsome farms, and he himself retains something like 15,000 acres.

He sold, he told me, because it was very difficult to farm on so large a scale. There was a great risk in having so much land under one or two crops. The small farmer could easily keep his place under constant cultivation, under his own supervision, and would have a greater variety of crops. If he lost on one, he could make on another. In other words, this gentleman practically admitted that the political economy of the small cultivator is superior to that of the large ones, and his self-interest works more accurately and successfully than that of his great neighbours.

This gentleman did not conceal the fact that the progressive land-tax was one of his reasons for selling-not so much for what it was, as for what it might be. $\mathrm{He}$ said this with the air of conviction of the large landowner who has felt the tax. He was evidently in a very cheerful state of mind over his sale. There was not the least suggestion of any feeling of resentment against the policy that was making the large landowners willing to allow the community to become their best customer. 


\section{LANDLESS MEN HAVE PREFERENCE}

Mr. Charles B. Spahr, in his investigation of bonanza farming in the Northwest given in the "Outlook" of November 4 , I 899 , points out that the tendency to concentration has been reversed, and that the farms are being split up, and in the "Outlook" of January I3, I900, the same tendency is shown to exist in the large estates of Argentina.

The small owner is competing out the large owner in New Zealand agriculture as he tends to in other parts of the world, but in some points the small man is still inferior. For instance, in the "closer settlements" the small men produce wool of inferior quality, as they cannot afford to go in for animals of high breeding. This they will have to remedy by co-operation, or else New Zealand will have to do as Victoria has done-set up a government stud.

Not far from Elderslie is the Ardgowan estate of 4234 acres, which the government took by condemnation for $\$ 173,000\left(£_{34}, 600\right)$ and has cut up into 65 farms and plots ranging from 5 to 364 acres, and rented at 5 per cent. of the cost to the government; or from $\$ 1.37$ ( $5 s .6 d$.$) to \$ 4$ an acre a year for 999 years.

There have been no failures among the tenants on the Ardgowan estate except one, and he was the most capable of them all, the failure being due solely to financial reasons.

One of the settlers here was a woman who had been a domestic in Oamaru. She and her husband now had fifteen acres and were doing well. Her father, she told me, had been a farmer. "Land," she added, "runs in our blood," but some of it I saw had worked through to the outside.

At Tokorahi among the settlers were men who had been clerks, farm labourers, etc. Two of the most successful had been employed in a bank.

At Maerawhenua a tall, shrewd, characteristic specimen of the transplanted Scotchman told me how, when it was in the hands of the private owner, he had been a "cropper" on 
the land he now holds. The government gave him and the other croppers, as is its custom, the privilege of continuing on the land they occupied. The rent under the private landlord had been fifteen shillings an acre. Now it was only ten and one half. A neighbour had had to pay fifteen shillings, which had been reduced to seven.

"Why does the government," I asked, "let its tenants have the land for so much less than the private landlord?" "Because the government wants no profit," was the reply.

My Scotchman and all his neighbours were doing well. This settlement had been made after Cheviot had been established, and the mistake made there of sections too small had been remedied here.

At Roimata, Pawaho, Paparangi, and some other points near Christchurch, Lyttleton and Wellington, may be seen settlements which the government has started in order to give the workmen of the cities homes in the country. The village settlements established from the time of John Ballance down to the present day, of which the latest examples are to be seen at Cheviot and Waikakahi, are for workmen, but not for city workmen. But the land policy of New Zealand has not forgotten the need of suburban homes for urban workers. This is a project dear to Premier Seddon's heart. He often refers to the huddled quarters of the workingmen in Wellington and other cities, bunched up under the hills, with a death-rate far exceeding that among the well-to-do. "Their high rents and high deathrate," he says, "make them slaves." He dwells with enthusiasm upon his plans for taking them out of town a few miles, giving them an acre or two of ground, with frequent workmen's trains, and rent at half the price they pay in town.

But the Land Department has not been able to execute these plans with the success that has attended its efforts for 


\section{LANDLESS MEN HAVE PREFERENCE}

the farmers' sons. This has been partly due to a defect in the law, which gave compulsory powers of purchase of estates near the cities only when they were of five hundred acres or more. This was remedied in the last session of Parliament. For the purposes of providing workmen's homes the government may now compulsorily take land in small parcels up to one hundred acres in towns of 15,000 inhabitants, or within fifteen miles of their boundaries. It is only by compulsory purchase that anything can be done for suburban homes for workingmen. Obviously owners of land in the vicinity of the cities are not under the same economic forces making them willing to sell, that operate on the owners of large estates away from the cities. The only way to get their land at a fair price is to take it by condemnation.

Another difficulty in the way of suburban settlements has been the inadequate train service, but this has now been changed for the better.

The workingmen complain that the requirements as to improvements in the suburban settlements put the acquisition of this land beyond the reach of most of them. The workingman, taking one of these plots, must, within a year, build a dwelling-house worth at least \$I50, within two years must build such a fence as the law demands around his lot, and, within three years, must have at least one quarter of his land fenced off and under proper cultivation as a garden or orchard. These requirements imply possession of quite a little capital.

On the other hand the government will advance the workman, if married, \$100 toward the cost of these improvements, and, if a bachelor, $\$ 50$.

The very broad definition given to "workman" by the New Zealand law is another reason why the intention that these settlements should inure especially to the benefit of 
the artisan class has not been realised. A "workman" in New Zealand, according to the law, is any man or woman, twenty-one years old, who is doing manual, clerical, or other work for pay, and is worth only $\$ 750$ or less. At the settlements which I visited I found persons of almost all classes except what we Americans would call "workmen."

Very little is being done with this form of settlement now. For one reason, the areas have been too small, and there has been much disappointment that the workingmen -in the artisan sense-have not taken more advantage of the opportunities offered them. Instead of being taken up by them, the public allotments have gone into the possessions of little shopkeepers, widows with a little money and with sons who were working at a distance, people who had no manual occupation-not by the real workingmen for whom it was intended.

Pawaho was opened in April, 1899, five miles out from Christchurch, and was taken up immediately. Twenty families are now living there on pieces of land varying in size from half an acre to two acres and a half. This land rents for from $\$ 4.50$ to $\$ I I .50$ an acre.

At Wharenui, a new settlement four miles from Christchurch, the land has also been taken up, though there is no tram and no railroad connection, and the only means of communication is by coach. The sections here are of one to three acres and rent at $\$ 17.50$ an acre.

In the suburbs of the uniquely beautiful city of Adelaide I visited the "Homestead Blocks" which are to be found near all the large towns of South Australia. Here workingmen, shopkeepers and other persons of small means are given a chance to get land enough for a homestead and a good garden. The "Blocker System," as it is popularly called, is not for farmers. They can get land under the land act. It is for those for whom the possession and cultivation of 
a piece of good land are not the main business, but to whom land may be a help, and when other occupation fails possibly their salvation. It aims to decentralise the people ouit of the cities into the country, and its motto is, "One family, one homestead."

So South Australia under powers of compulsory purchase, like those of New Zealand, has been buying back land from private owners around the cities and cutting it up into blocks of one to five acres near the towns, and of as much as thirty acres in the country.

The prices the colony must pay are high of course; so high that for the last year or two it has bought very little for these settlements.

The blocks are leased, not sold, and the tenants must pay five per cent. on the cost. This makes the rent average about $\$ 6.30$ an acre as far as ten miles out of Adelaide.

To be eligible the "blocker" must be one who makes his living by his own labour; not necessarily, however, what we call a workingman. After the tenant has made improvements on his land the government will make him advances on the value to the amount of \$250. As one of the officers expressed it, "If a man has the walls of a house up, the government will lend him money to finish it." Less liberal than New Zealand, South Australia, in case of forfeiture, forfeits the improvement as well as the land.

The blocks are intentionally made too small to furnish the whole living of the occupant, though in some cases, with intensive culture, the holders of twenty-acre blocks have been able to live on the land alone. Owing to the prohibitive prices asked for land by owners and to other causes the system has not flourished. During the last year there were 3692 acres let for homesteads, but the larger total of 4207 acres was cancelled. This has been due largely to terrible 
droughts which ruined the crops of the "blockers," and at the same time made the outside employment which might have saved them very scarce.

The blocks I saw in the vicinity of Adelaide were many of them most attractively cultivated, and were occupied by a very desirable class of people.

The advantages of this system, taking people out of the cities, adding the healthiest of all industries to the repertoire of livelihoods, giving an unfailing resource in times when other resources fail, keeping near the cities a supply of the best kind of labour, offering a new chance to men who might otherwise be lost, do not need to be dwelt upon.

The experiments of South Australia and New Zealand in this direction of suburban allotment-not quite accurately called workingmen's settlements-though in the right direction, are still only in the experimental stage. In none of the colonies could this form of settlement be considered the success which in New Zealand the Improved Farm Settlements and the "closer settlements" as at Cheviot certainly are. The enlarged powers to acquire land in and near the New Zealand cities, given by the last Parliament, will soon produce results, and these should be important.

That there is a growing need for these allotments and that the workingmen and others who would occupy them can make profitable use of the land, is proved by the rents which private landowners are able to exact from small men in the neighbourhood of the towns. Seventeen dollars and a half to twenty dollars an acre ( $\mathfrak{f}_{3}$. Io to $\left.\mathfrak{f}_{4}\right)$ are easily got, for instance, in the neighbourhood of Christchurch, New Zealand. The same land when leased in farms can command only seven and a half to ten dollars an acre (30s. to 40s.). By virtue of being, though in so small a way, capitalists, the farmer pays less than half what the workingman who has no capital must pay. 
The New Zealand democracy, which gives the ballot and old-age pensions and seats in Parliament to the Maoris -and even this year a place in the Cabinet, where the Honourable James Carroll, a Maori, sits as Colonial Secretary -does not leave them out of its provision of lands for the landless. A special investigation by Parliament, beginning in I 893, ascertained that there were 4233 Maoris, who either had no land at all, or not enough to live on. To meet their wants an area of 169,289 acres was withdrawn from other settlement, and set aside for the landless natives. So far 24 I 5 have been taken care of, and the needs of 1828 are being attended to.

Co-operative villages have especial recognition in the New Zealand land system. Ordinarily land is distributed among the applicants by ballot, but this would operate as a bar to the acquisition of land by co-operative associations whose members must, of course, live together. To meet this need the government has devised the "Small Farm Association" settlement. People who want to establish a co-operative village do not have to go into competition with other persons for their land. They need not go to the ballot box for their allotments, with the certainty of being scattered. If twelve or more people, associating themselves together for mutual help, make application to the Minister of Lands, he will allow them to select, subject to his approval, a block of land of not more than II,00O acres, provided there is a settler for each 200 acres in the block. No one can hold more than 320 acres. This land is held under the 999 years' lease.

These settlements have been, perhaps, the least successful ventures New Zealand has made in the disposal of its land, but the failure has not been the government's but the settlers'. These co-operative associations are very apt to have more enthusiasm than experience. "The difficult art of living together" is difficult, as we know from George Eliot, 
when only two attempt to practise it. The results of cooperative experiments in living and working together in New Zealand, on the state farm to be spoken of, and in South Australia, and in New South Wales, show that very few people are as yet ready for co-operative life. The path to the larger family this life promises, like the path to democracy, is a long and weary one, though it is one from which the feet of the people will never turn back. These co-operative associations, in their eagerness, have taken up too much land and have not chosen it wisely as to situation, quality of soil, etc. In the year $1897-98$ there were 172 forfeitures and surrenders out of 1204 holdings, and in the next year there were i 6 more. There are now 812 selectors in these co-operative associations, holding 142,666 acres, which, with all the failures acknowledged, is still an interesting and respectable showing.

The state sometimes puts its rents too high. The procedure for reduction is cumbersome, and there is an agitation for "A Fair Rent" bill. Revaluation is possible under the present system only upon the tenant's abandoning his land. After twelve months it is offered again. If no one bids higher than the value charged the old tenant he can go in again at a reduced rate. A tenant in such a case could only trust the magnanimity of his neighbours not to bid to get his section, but few men care to risk taking a lease at a price at which a former tenant could not make ends meet. Among other concessions, the law provides that in case of natural disaster a year's rent may be remitted, but not to tenants who are in arrears.

This system of "closer settlements" is not the creation of an individualistic peasant proprietorship like that which exists in France, and such as is aimed at in Ireland by the new policy of the English government, but a collective proprietorship and partnership of people and state. In New Zea- 
land the state is interested pecuniarily in the rent, and therefore has a pecuniary interest in the prosperity of the tenant. It must weep with him and laugh with him. It is compelled to watch out for his welfare. It is therefore a very real public self-interest which sets the state to furnishing lime and poultry experts, London agents, low railroad rates, free cold storage, cheap money and all the rest that we tell of in "Government \& Co., Unlimited."

As we have shown, New Zealand is making a profit of five per cent. on its investments in "land for the people." There are different plans for disposing of these profits. At the end of the year I 899 the department expected to have accumulated profits of about $\$ 100,000$. A sinking fund is proposed by some; another plan is to buy a farm with this money. Then the government could say to the people, "Here is a farm that has cost you nothing." Its profits could in turn be added to the fund for purchasing more farms, and thus the system could go on snow-balling itself into larger and larger proportions.

Part of the profits of the settlements are now being used on public works in their vicinity for the benefit of the settlers whose labour has created the profits. Thus at Cheviot, the Land Department appropriated last year $\$ I_{5}, 000$ of its profits for roads and other improvements, and is likely to appropriate a similar sum this year. Following the precedent of using the profits of the advances to settlers to reduce the rates of interest, the profits of the land operations might also be used to reduce rents and the Premier has promised this shall be done.

I had the opportunity of being present at the balloting to distribute among the people applying for them the farms cut out of a valuable property which has been "resumed" -the Waikakahi estate. This consists of 47,320 acres in South Canterbury, between the Waitaki and Waihao 
rivers, bordering, like Cheviot, on the Pacific, with blue mountains on the sky line on the other side, a beautiful stretch of country between the ocean and the mountains, fertile, rich and wholesome. It had been for many years the property of a great sheep raiser. It was a fine tract of farming country, well coated with dark loam, sometimes three feet deep, and traversed by numbers of streams draining the wide, open valleys. There are rich alluvial flats and rolling downs. The land was "in good heart," as it had not been exhausted by cropping, but where it had been cultivated the yield had been something extraordinary. As much as fifty to seventy bushels of wheat and 120 bushels of oats an acre had been threshed from some of it. There are three railway stations on the land or near it.

Its owner, who had been a poor boy in the western Highlands of Scotland, came to New Zealand thirty-five years ago, and bought a few acres at ten dollars an acre. From the profits of his sheep-raising he bought some more and kept on buying, until he finally found himself the owner of this magnificent estate and a millionaire in thirty-five years. He sold because, as he said to one of the officials, "If I don't sell, you will take it by-and-by."

In addition to this estate he had another of 16,000 acres which he gave to his nephew, without waiting for the progressive land-tax and the progressive duties which would have been levied upon his death.

The price paid him was $\$ 1,600,000$ for 47,000 acres, about $\$ 34$ an acre. The owner took $\$ 1,250,000$ of this sum in debentures running for ten years, paying three and three fourths per cent. interest. The balance of the money is got from the Post-Office Savings Bank, or the investment funds of the Life Insurance Department, or from the Public Trustee. The owner kept the homestead, which, according to the act, he has a prior right to. In this way the govern- 
ment dispose easily and profitably of a part of the property which otherwise might become a burden.

The New Zealand newspapers were full of the official advertisements of the sale, and of news articles; for the distribution of such an estate is an event. The ballot was to take place at the little town of Waimate, and when I arrived I found the hotels, boarding-houses and private residences filled to the eaves with people who had come to submit their applications to the scrutiny of the land board, and to witness for themselves what fate would do for them in the casting of the lots. Even the railway carriages were turned into sleeping rooms.

The estate had been divided into 140 farms, ranging from 45 to 1473 acres. Of these 126 were offered to the public on lease in perpetuity and fourteen were offered as small grazing grounds, and for these there were 3242 applications from 8I 3 different applicants. There have been cases where there have been over one hundred applicants for one piece. For thirty-nine sections in another settlement there were 2500 applications. Every applicant, besides filing the formal paper required by law, has to appear personally before the land board to answer any further questions they need to ask to satisfy themselves that he has the money, knowledge and other qualifications which so dignified a person as a state tenant must possess. The land boards had been sitting in different places in the colony for several weeks to examine intending settlers, but a number were still to come before the board at Waimate on the eve of the distribution. These examinations are for obvious reasons usually private, but the board, anxious to let me see as much as possible of the inner workings of the system, and knowing that one so far from home as I could not offend the susceptibilities of the applicants under the fire of the official examination, did me the courtesy to allow me to sit with them. 
The land board met in one of the ante-rooms in a little white court house of Grecian design, on the main street, and the court room itself was given over to the thronging crowd. The examination took place at night. The dingy court room, lighted by a dull, flaring lamp, was filled to the doors with eager, patient faces. It was a plain lot of working farmers and their wives, and of young men and young women, for women can apply for land on their own behalf. There were also villagers, farm labourers, workers on the railroad, constables, shepherds and domestic servants. Brothers and sisters, husbands and wives, came together. Most of them had brought their lunch to carry them through the long hours of waiting.

One applicant had come from Queensland; there were some from the North Island; one from Canada had been in the Mashonaland war. There was a man who had been in land rushes in America, and, guessing my nationality, he said to me as I went past him, "This is not much like Oklahoma." Every applicant had already submitted his answers to the formal questions put by the government, and which I copy here to show what it asks those whom it may admit as tenants of its lands.

I. How old were you last birthday?

2. What means (including stock and agricultural implements or machinery) do you possess for stocking and cultivating the land and erecting suitable buildings thereon, and what is the total value thereof?

3. Have you means sufficient, in your estimation, to enable you to profitably work the land and fulfil the conditions of the lease? If not, state how you propose to do so.

4. What experience have you had in cultivating agricultural land or in dairying?

5. What is your present occupation? 
6. Are you married? If so, has your wife (or husband) had any experience in cultivating land, in farm work, or in dairying? Give particulars.

7. Have you any family? If so, state the number and sex of your children now living with you, and their ages.

8. What land do you hold or have any interest in?

9. What land does your wife (or husband) hold, or have an interest in?

IO. Is the rural land (if any) mentioned in answers 8 and 9 insufficient for the maintenance of yourself and your family? If so, give your reasons.

II. Is the town or suburban land (if any) mentioned in answers 8 and 9 insufficient for a home for yourself and your family? If so, give your reasons.

The conditions as to residence and improvement are very strict. The successful applicant, to hold his property, must begin residence within a year, and within a year must put on improvements equal to two and one half per cent. of the value of the land, and within another year two and one half per cent. more, and within the next four years another two and a half per cent. He must have his fields fenced, in accordance with the stipulations of the law, within two years, He must once a year cut and trim all the hedges on his land, and must also keep it clear of all broom, sweet-briar and other noxious plants. He must not take more than three crops from the same land in succession, and one of these crops must be a root crop. After the third crop he must put the land down in grass, and let it remain in pasture for at least three years before beginning to crop it again. If his farm is more thian twenty acres he must keep not less than one half of it in permanent pasture. He is not allowed at any time to remove from the land nor burn any straw which is grown upon it. If the tenant neglects these 
and some other less important conditions the land commissioner will have the work done for him, and the cost of it is made recoverable in the same way as the rent.

Some of the old-fashioned people, used to the immunities of the freehold, resent the inspections of their premises necessary to ensure their compliance with the terms of the leases. "It is a good deal like being at school again," one of them complained. "The Ranger" is the title of the inspector of leasehold properties. "If you find the Ranger in your garden," a leaseholder said sarcastically, "counting the gooseberries you mustn't mind it. It's part of the system."

The women were called in first, one by one, from the court room before the land board. "We should deal first with the women who are waiting," the chairman said. The first woman who appeared before the board, after answering their questions, said, "I am taking this up entirely for the benefit of my family of seven children."

The next was a domestic who had eight children. She had saved and made \$30oo. Her father came in on his crutches to vouch for her. Her mother and two sisters were with her. The three girls were all dairymaids, and all were balloting for the same section in order to increase the chances that some one of the family might get it. "Have you any other land?" the father was asked. "No, except a cemetery lot not yet occupied," he replied.

Two sisters, domestics, applied for a piece for which there were one hundred and sixty applicants. They had entered, they said, to give their father, who was one of the applicants, another chance.

A husband and wife were applicants for the same section. "If I get it, it's his," the wife said. "If he gets it, it's mine."

One of the points as to which the board had to be most 


\section{LANDLESS MEN HAVE PREFERENCE}

careful in its search was that the applicant was not already the possessor of land, for here, by the law, "landless men have the preference." One of the first men to appear had a piece of land, but he explained to the board that it was the "worst piece on the Waikakahi River. I have to go out to find work to keep it, instead of its keeping me." But the board was inexorable. "You are not landless," they said. "We are obliged to give the preference to the landless." "It is a serious thing for me," he said, and heaved a big sigh and went his way.

The next applicant held one hundred and sixty-eight acres of freehold. "That bars you," the board said. "You are not landless. You should have sold your land. You could then have had a chance."

The next man had madè over a lease of some land he held after he made application. He was barred. "You should have been free."

The next had sold his lease to take effect if he got the section he applied for. If he did not, he would still hold his section. "Ineligible."

"I have been working on the land all my life," said the next man, "but I have no land." There was an extra touch of heartiness in the "Ay" with which the land board approved his application.

"If I had fifty acres of good land I would be all right," said the next man. He had all the requirements but the land-knowledge, experience and money, or its equivalent. Each applicant must have five dollars in cash, or its equivalent, for each acre for which he applies. As to his resources, this man said he had horses, drays, cows, reapers, binders. "Me wife has thirty pounds in the post-office, and I have forty pounds meself, besides me furniture and an acre of potatoes."

"I put in my application for the largest sized piece of 
land I thought I could work myself," said one of the men. The board thought that he had asked for more than he could manage and cut his name out of the applicants for large sections, but allowed him to remain with those who were balloting for a smaller section. The applicants were allowed to apply in this manner for more than one section.

One man withdrew because he had become convinced that he had not money enough to carry on the section he had applied for. "There is a great deal more fencing to be done than I thought."

The applicants were carefully questioned about the amount of money they had in the bank or some other safe place, or in the shape of some equivalent. Their means may be part in cash, part in animals; unsold crops and wages due all count as part of the needed funds. There were suspicions that some men had qualified themselves to pass the examination as to their financial resources by borrowing money for a day or two. There was plenty of talk about men who got the use of a hundred pounds for two days for a pound, but no evidence was forthcoming. "Any number of people are putting money in the bank to make up the amount. If I had known it I could have done it, too," said a man who was rejected because he had not the amount of cash the board required.

"They have all sworn," the chairman replied, "that it was their own. They will probably be prosecuted for perjury. You wouldn't like that?"

The village constable was an applicant. If successful in the ballot he proposed to resign his position. He had $\$ 4200$ of his own and his wife's, the savings of forty years. Needless to say, he was approved.

One of the farm labourers who applied and was approved had $\$ 4500$ to his credit: "A careful, thrifty man," the board said as he retired. 
"Where did you get your money?" the board asked one. "Out of my hard earnings at work I saved it just to get such a piece of land as this at Waimate." "Where have you kept that money?" he was asked. "In my pocket and my wife's," he said. No banks for that man. He was a member of the stocking brigade.

One of the applicants calculated ten acres he had in potatoes as worth $\$ 1,250$. The board did not think them worth so much and rejected him for insufficiency of capital. "I am done," he said.

In several cases husbands and wives applied independently for sections. As the distribution is made by ballot-wherever there is more than one applicant for the same piecethey are not likely to have adjoining sections, and no arrangement is possible under existing regulations by which they can be assured sections together. And each has to live on his or her own section. This sort of divorce is felt to be against public policy, and the Premier promises to submit to Parliament an amendment giving families a preference in the distribution, so that husband and wife may get sections together.

A plate layer on the railroad and a brakeman were among those examined. "I intend," the latter said, "to make my home on it."

Some of the men indulged in little touches of humour. One, asked if he had any encumbrances, said, "Three children."

A labourer, who had been on the estate for twenty-four years, had as his substitute for cash one hundred and fifty sheep, seven horses, some cows and some furniture. "Any amount of money I want I can get," he said. He was approved. He and the shepherd who came next and who had been on the estate for thirty years, got the land for which they applied-that on which they had been living-without 
having to run the chances of the ballot. The law gives this preference to the men employed on the estate, to enable them to save their homes. Surveyors are instructed to cut up the estates so as to put land enough with these homes to give a living to the occupant.

A brother and sister came in, twenty-two and twenty-one years old, and said their father had given them \$I,500 to start with. The father was called in. "Will you have any interest in the land?" he was asked. "No, sir, they are old enough to look out for themselves," he said. Their application was approved.

A teacher of agriculture applied. "I have had very dittle experience in farming," he confessed.

"What experience have you had?" was asked of another. "I have spent all my life on the ground," was the answer. "Have you any land?" "No, sir."

It was an orderly crowd, and the streets of the town became quiet the moment the board adjourned. The next morning at the appointed hour the people surged eagerly into the court room, filling the doors and the corridors to witness the balloting. The question arose who should be "scrutineer"- the representative of the applicants who draws the ballots bearing the fateful numbers and announces to the crowd the successful number in the case of each section. Several voices said, "Let the people nominate," and by acclamation the Democratic Traveller from America was chosen as scrutineer, and given the honour of helping the fates in the distribution among the people of one of the finest estates that has been resumed by the democracy. Just as the ballot was about to proceed one of the land board arose and made a public protest against a decision of the board the night before in the case of a man who had seven children, and though he had land found it insufficient for their support and had to go out 
to work every day in the week. The board had decided that it could not consider him landless. "It is not justice," said this member of the board. "The board have admitted men," he declared, "who had thousands of dollars' worth of land, and rejected men who could not make a living on the pieces they had. The meaning of landless under the law," he said, "is the not possessing land enough to maintain a home. I deem it my duty to protest against the proceedings."

The protest was unheeded; the action of the board was entirely within its discretion, and the people seemed confident that it had good reasons for the exclusion.

For each farm to be balloted for there was a sheet on which were entered the names of all the applicants for it, arranged alphabetically and numbered in due order from one onward. The clerk of the board read aloud the name and description of the first farm to be contested for. The great crowd grew still with excitement. There was the sharp clicking of the ballots, one for each applicant, and bearing his number, as they were thrown into the ballot box-"The little hurdy-gurdy that tells the tale," as one of the bystanders said.

The scrutineer, as the representative of the people and especially of the applicants, carefully and even ostentatiously supervised every detail of the placing of the ballots in the box, seeing that there was a ballot for every applicant and that the box was properly closed. The crank was turned, and the box, with the ballots rattling inside of it, revolved rapidly to mix up the lots, so that there could be no possibility of "fixing the returns." The scrutineer, not blindfolded, but standing with his back to the box, put his hand behind him, and, praying that luck might favour one of the red-cheeked dairymaids sitting breathless in front, drew forth the fateful ballot, and held it up in front in full view 


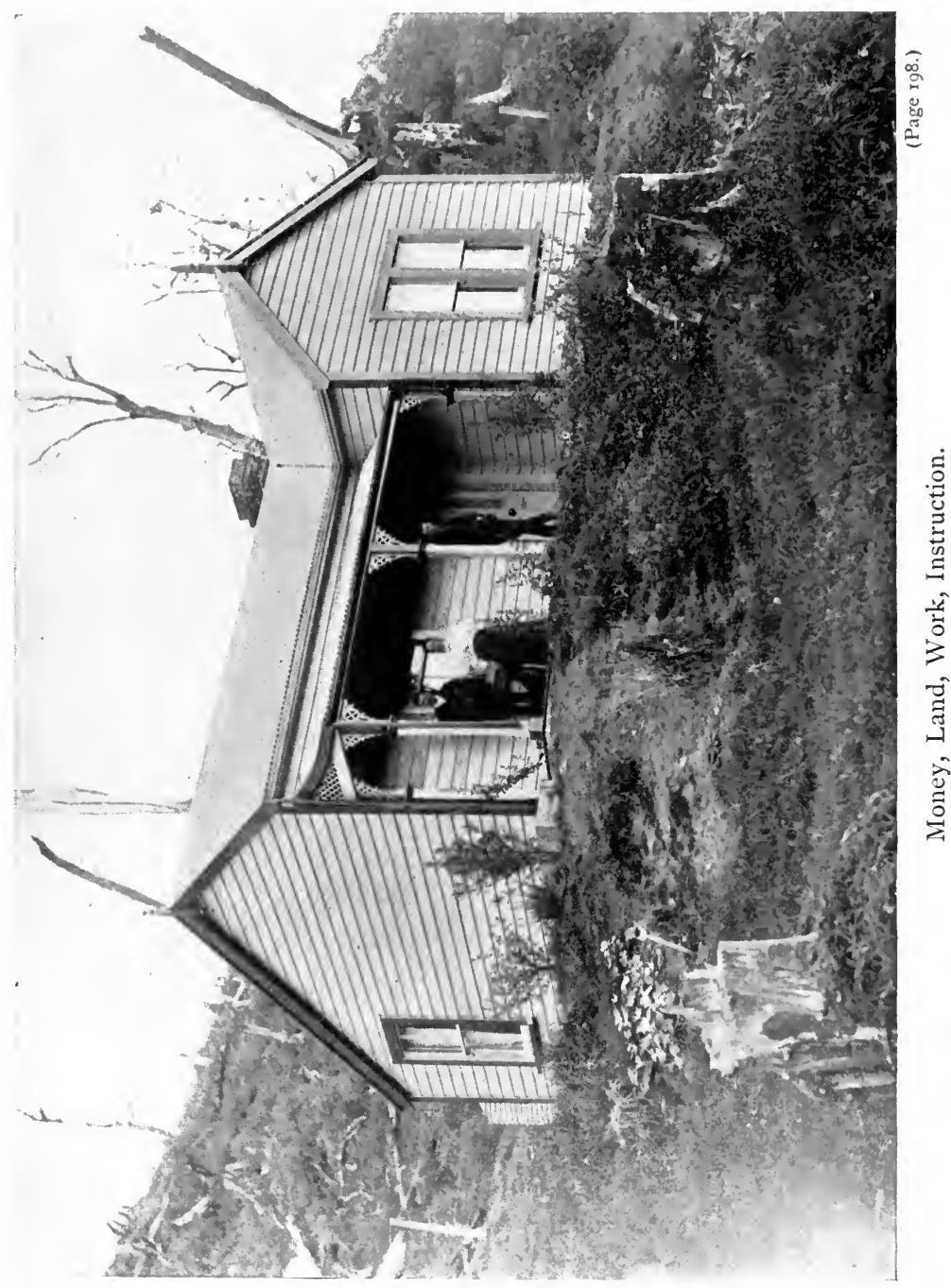



of every one and read aloud the number upon it. Thereupon the name corresponding to the number was given out by the secretary of the board in sonorous tones. If the happy recipient had friends and neighbours present, or if he was a man generally known, the announcement of his name was received with cheers.

The man for whom the scrutineer drew the first section was most enthusiastic. He came to the scrutineer afterward and insisted upon knowing "the name and American address of his mascot." "You have brought me great luck," he said, "and something from the first fruits of that farm shall be yours." There is still time for the arrival of those fruits.

Part way down the list the scrutineer, calling out the number on the ballot he had just drawn, saw a delighted flash leap over the face of one of the eager group of young women in front of him. The dairymaid had got her farm. "It was not much like Oklahoma."

This little paragraph, which I cut out of a New Zealand paper in November, I899, makes perhaps a fitting conclusion for the history of this resumption of land.

"During the last year more houses have been built in Waimate than in the preceding ten years. Local carpenters can hardly cope with the demand. Many houses are in course of erection at Waikakahi also." 


\section{CHAPTER IX}

TRAMPS MADE TAXPAYERS

AlL these people we saw balloting at Waikakahi had money and experience. What is there in New Zealand for the man who has no land, nor money, nor work-the unemployed, the tramp? New Zealand found itself face to face with this question at a very early stage of its history- 1874 - when its national life was hardly a generation old. Though too new a country then to have any right to such a disease of national old age, it had it, as a result of both its land policy and the public works policy of 1870 . Part of the large sums borrowed then in England were used to assist immigration. Sir Julius Vogel sent word to the agent general in London to find and forward fifty thousand immigrants in six months. They began coming in a flood. Public buildings and every available place were filled with them. It was the policy of making haste to be rich. One of its fruits ripened twenty years later in the collapse of the Bank of New Zealand.

To take care of the immigrants they were put at work under experienced direction on blocks of Crown land from one quarter to five acres in area, on or near the railroads. They were set to building whares-the Maori word for hut - of sod. No one knew which building he was to occupy, so all were done with equal care, and when completed they were balloted for. The people were allowed to occupy these huts and the land rent free for the first 


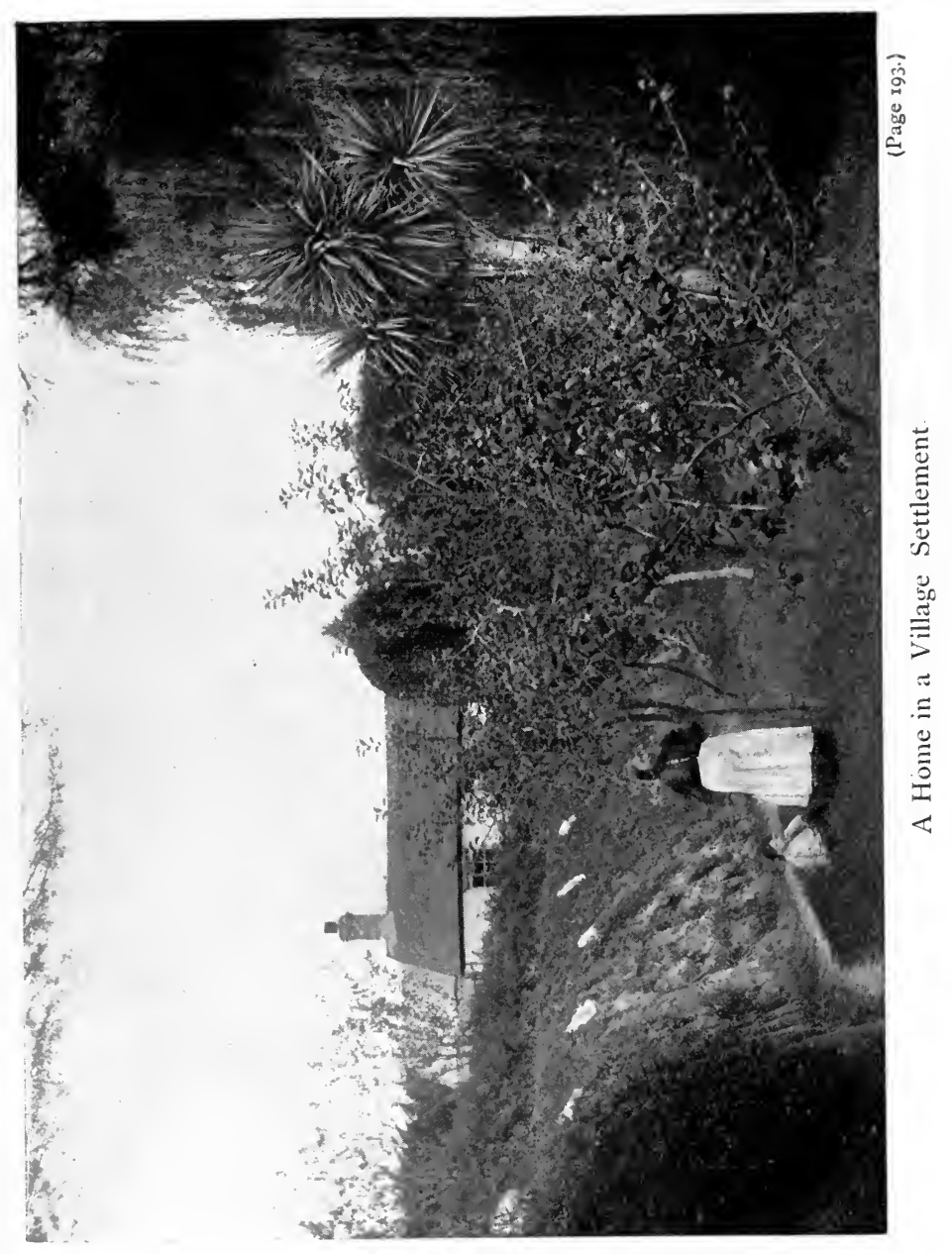



year; then a charge was made of fifty cents a week for three or four years, and after that they were expected to look out for themselves.

Among other reproductive works, the men in these early days were set to making plantations of trees which are now flourishing groves along the lines of the railways.

The main idea of the scheme was to give temporary relief, not to establish permanent settlements, though some of them still survive, as at Arowhenua. The Minister of Lands was then the Honourable William Rolleston, who has been a notable figure in New Zealand development. At this early day, in answer to a delegation of the unemployed, Mr. Rolleston laid out a complete programme of village settlements of a permanent character, with help from the Treasury in building homes, but he belonged to the wrong party - the Conservatives-and was never given rein to realise his ideas.

At Arowhenua the visitor sees snug little cottages, bordering on noiseless turfy streets and surrounded by a wonderful profusion of flowers, foliage and garden products. Instead of fences there are luxuriant gorse hedges. Every foot of the small allotments is in thrifty use, but there is always along the walks and around the houses room for flowers. These places have all become freeholds, as the holders were allowed to purchase them. In the houses we visited the husband would usually be found away from home, busy labouring for some near-by farmer in the harvest field.

A good question to open up conversation with the housewives as we encountered them was, "What was your ship?" referring to the vessel in which they had arrived from England a generation before as assisted immigrants. The Lancashire Witch, The Pyrrhus, were among the vessels that these women remembered gratefully. The sod whares still 
stand on some of the lots, but most of them have been replaced by wooden cottages of attractive appearance.

One of the settlers, a sturdy Englishman, of Kent, who has been on his present place for eighteen years, had been a leader of a union of agricultural labourers in the old country. They had been reduced in their pay by the Farmers' Union from twenty shillings a week to fifteen, from fourteen shillings to twelve. They formed a Labourers' Union, and were promptly "locked out." The invitation of New Zealand coming at this time, this man and some of the others had emigrated. He and his sturdy wife had no children, and, he said, "no need to want them." He would have preferred to stay in England, he told me, but he had to leave home because he had made himself a marked man.

A couple who lived in a house near by had been twentyfive years in possession of their home on its half acre of land. They had seven children, all doing well. This man had also been a farm labourer in England. His pay had been nine or ten shillings a week. He could not make enough there, he said, to get food to eat. "Being a labourer in England was pretty near being in prison." In New Zealand he has a beautiful home, all his children have lived and are prosperous.

A sailor was another inhabitant of this village. Sailors are frequently among the successful settlers on the land in New Zealand. The life of a sailor makes a practical man, one who is able to turn his hand to anything. At a settlement near Christchurch a sailor, who was adding to his already commodious home, in explaining to me the lack of success of his neighbours, said, with emphatic pantomime, "They lack this," pointing to his hand, "and they lack that," pointing to his head. The sailor at Arowhenua had an acre of land, and had brought up two children. When 
Cheviot was started he had gone there to work at one of his trades-that of horse-rug making-but, not succeeding, had returned.

The driver who was taking us around and who was very much interested in our inquiries remarked to me, as we left this place, that if the same people should come now they would not do so well. There were more men now, he said, than work. When these men came there was a sad need of them in the country, and they were in sad need of the work it had to give.

One of the lots was handsomely improved with a brick house which had recently been sold to a small capitalist who would rent it out. A settler, pointing to his very attractive home, said, "Milk did that." $\mathrm{He}$ had been a miner in Cornwall, and brought over five children whom he "did not want to go underground." He was a free, not an assisted immigrant, and had paid $\$ 62.50$ for his first quarter acre. His house cost $\$ 2,000$, and stands in effective contrast with the original home near by.

In I886 the towns of New Zealand were again filled with workless men. This led the Honourable John Ballance, then Minister of Lands, to revive the idea of settling the idle labour on the idle land, but this time permanently, not temporarily. This he made his specialty. It was a scheme which caught the eye of the country and has never since been allowed to die out.

Dromore was one of the settlements then inaugurated. A population of eighty-four people was gathered here. Nine hundred and twenty-five acres of Crown lands were selected for them-not given, but rented. Three hundred dollars was advanced them to build houses. In four years - I89I-they had put on the land in buildings and other permanent improvements $\$ 5785$, and the Treasury had received in rents and interest from them $\$ 1683$. The arrears 
were nil. The state had given these men and their families a chance to better themselves, and they had bettered the country as well as themselves, for they had opened up the land, improved the roads, increased the public revenue. Other settlements were started, and money was advanced to the people as loans to help them to fell the bush, put the land into grass, and establish themselves in homes.

These subjects of economic resuscitation lose none of their political rights and none of their consciousness of them. The settlers at Eketahuna took timely advantage of the presence of the Minister for Public Works and members of Parliament on their electioneering tour last year to call their attention to the fact that they had to go twenty-eight miles to market and the post-office, although there was a town within five miles of them, but inaccessible for want of proper roads. Ministers have their "ears to the ground" at election time, and the settlers received a promise that "during the next session they would be attended to."

"A delegation of workingmen is always sure of a hearing with the minister," said one of his officers. "Very likely some of them knew him when he was a workingman himself."

Premier Ballance began the crusade against the freehold which Minister McKenzie afterward carried out, and he withheld from these settlers the right to part with their lands. The men and women with their children thus planted on the land can be seen healthy and contented and in happy homes. The experiment has stood even the financial test, for the Treasury has made money by the venture. Times improved, and between 1887 and I89I no new village settlements were formed, but in the '9o's hard times came again, and New Zealand heard the bitterest cry of the modern world, that of men and women who want work, asking in vain to serve and be served. 
In his report for 1895 the Secretary of the Labour Department of New Zealand wrote in as anxious a strain as if he had been at the head of the same department of any of the effete nations of the world.

"There is," he said, "an unusual depression in the labour market and a corresponding difficulty in finding employment. This year the difficulty of providing for the floating bodies of workmen has been augmented by the addition to their numbers, and many settlers and others hitherto belonging to permanent labourers here, under the pressure of the scarcity of money, have recruited the ranks of the wanderers by helping to swell the number of the unemployed. The skilled trades have also contributed their quota, boiler makers, printers, painters, etc., stepping down into the ranks of untrained labour for the sake of employment on road works or railway construction."

In May, 1899, while I was in New Zealand, there were many complaints made against the government from more than one place, and public meetings were held to protest against its action in sending the unemployed from other parts of the colony to the public works in localities where the residents were themselves out of work. In one such place where twenty of the unemployed from Wellington had been sent to work on the railroads the representative of the district in Parliament wrote to the Premier that the names of fifty of his constituents out of work were on the register of the labour bureau awaiting the promise that they would be given something to do. He said:

"The labourers here have waited patiently for work. They are now disappointed. These men are very near to starvation."

The New Zealand idea is not to relieve the tramp or the unemployed temporarily with soup kitchens, street cleaning or potato patches, but to make a citizen and taxpayer of 
him permanently. He needs money, land, work, instruction, and the touch of a helping hand, and the democracy of New Zealand has been for many years attempting to perfect a system which it is hoped will give him a chance to get all of these. This policy we have seen developing, step by step, from the settlements of Rolleston to the village homes of Ballance, and it has been taken up and carried a good step farther by their successor, Minister McKenzie. The public gives nothing but the chance. It will help the man, if he will help himself. He must pay ultimately for everything. There is not a touch of charity. Not even in the helping hand. For the man who is saved from sinking by this hand of the democracy is himself a member of the democracy. With his very first stroke of work he begins to strengthen the democracy to help some one else. With that first stroke he begins to be a taxpayer; what he receives he gives, and this is the golden rule of democracythe reciprocity which our clumsy language calls equality.

In this policy New Zealand sought to avoid some fundamental mistakes in the management of the Australian labour bureaus for the unemployed. These gave the men food and shelter. The instantaneous result of this was to clear all the bush country and the sheep runs and the roads in Australia of the "swaggers" and "sun-downers" who were tramping for a living there. These men asked for nothing in the world better than food and shelter, with the climate of Australia thrown in. Three thousand were being fed in Sydney alone at one time.

An official of the Land Department, Mr. J. E. March, who was sent to investigate by the New Zealand government, on landing in Sydney saw nearly one thousand men at work levelling sand in one of the parks for their food. A pair of horses and a scraper would do more work in one day than these hundreds of men could do in two days, and 
the men knew it. He saw as many men outside the labour bureau seeking employment, which they could not get. There was plenty of land in New South Wales suitable for settlement. Just outside the city was some very good country admirably adapted for small settlements. Sheep were its only tenants. A large army of able-bodied men were doing fictitious work for their food, with a larger army at the labour bureau seeking work, while on the land that would have supported them and their families and thousands more, roamed a few flocks.

Another mistake made by the Australian bureaus had been to send men to employers who had labour enough in their vicinity, but wanted to put down its price. If the home labourers refused to accept reduced wages the Australian landowner would telegraph the labour bureau to send him men, and in this way the state was actually being used as an instrument to undercut the standard of life of its own citizens. The abuses which resulted from these errors of management absolutely stank in the nostrils of the whole community.

"In New Zealand we never gave sixpence," said Mr. Edward Tregear, the secretary of the labour bureau, "nor shelter, nor even railroad fare. We often advanced the railroad fares for workmen, and even for their families, but it must be repaid, and is retained from the man's wages."

Three departments are co-operating in New Zealand in this work of turning tramps into taxpayers-the Department of Public Works, the Labour Department and the Land Department. The last, in New Zealand, can give these men all three of the things they want-land, work and money.

Items like this from the "Wellington Times" are common in the New Zealand newspapers:

"The Auckland agent of the labour bureau has received 
instructions to forward an additional party of twelve suitable workmen to the Poro-o-tarao-Ohinemoa section of the North Island Trunk Railway. Applications from men already on the books will be received at the office of the bureau until noon to-morrow."

The Labour Department, through the register it keeps of the needs of employers and employés, and through its connection with the various departments-the largest employers-can find work if any one can. The Land Department has charge of the new country roads, and the Public Works Department has railroads and bridges and other public works always under construction. A man is sent to a private or public employer, as the case may be. The work may be at the other end of the colony, and he may not have a cent to pay his fare nor to live upon while going there, but that is no obstacle. The Labour Department advances him transportation and even subsistence-advances, does not give. If the work promises to be permanent it advances him transportation for his family. It will give him and them orders for meals and beds during their journey. The cost of this is to be repaid by the man out of his earnings, and the records of the experiment show but a trifling percentage of loss. It is the policy of New Zealand to keep the families of workingmen together wherever possible.

With the same purpose the men put on a piece of work are not displaced to give work to others, so that "all may have a chance." The chances for the other men must be found elsewhere. The men on a job stay there until it is done. Near almost all the public works one sees the cottages, comfortable, primitive, to which unemployed men who are working for the public have been assisted to bring their wives and children. Given this inch, they want an ellwhole acres, in fact-and a definite proportion of them look 


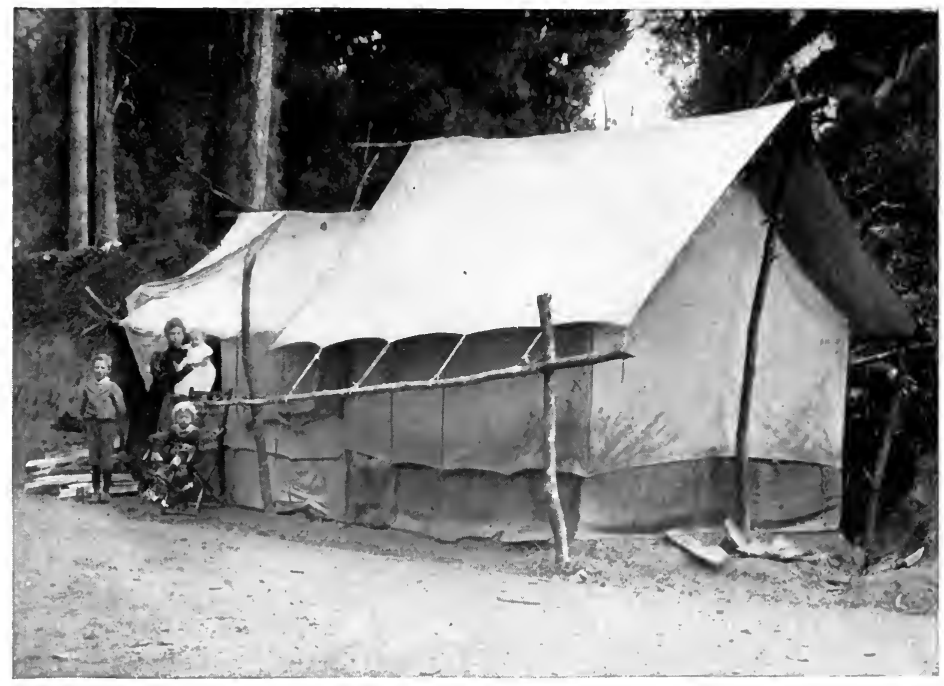

Families are Kept Together.

(Page 200.)

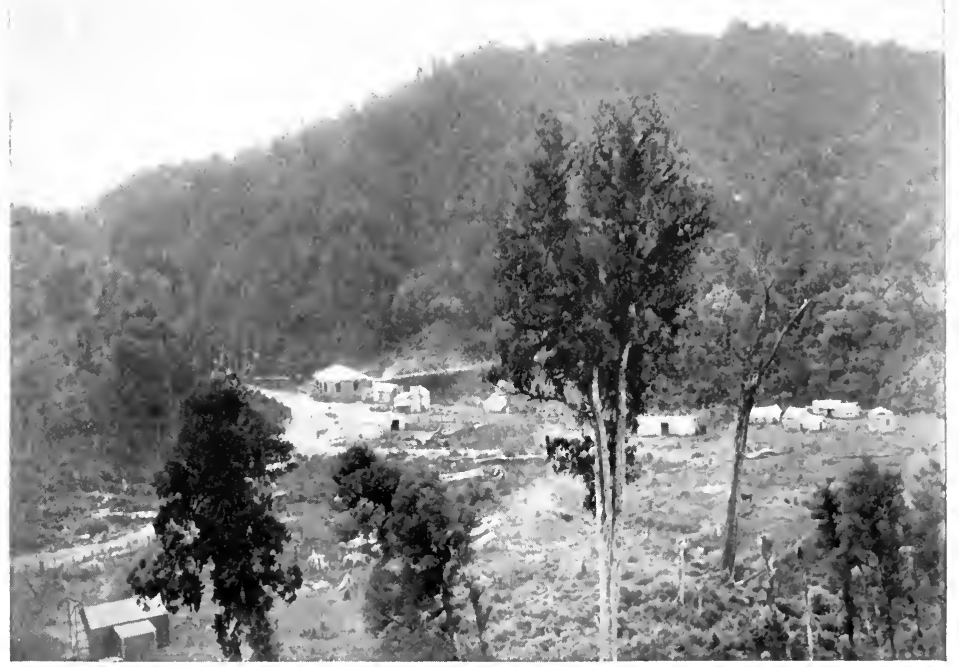

Waste Labour applied to Waste Forest.

(Page 204.) 

up land near by and become permanent settlers on Crown lands if possible. They and their families acquire a love of the country, and are glad to leave the city forever. A steady transfer of people from the poorer town districts to the country is being thus accomplished. Many who do not wish to devote themselves wholly to farming take small sections of land in the vicinity of their work. When their employment on the railroads or other public works has come to an end these men find something to do in the towns that spring up, and this, with their own little piece of land, keeps them going. A great deal of pains is taken to put these unemployed men at work where there is land to be had, and they are allowed-taught, in fact-to work alternately for themselves and the government. Roads are made to open lands, and lands are opened to create a demand for roads. Estates like Cheviot are cut up not simply to provide farms for the sons and daughters of the older settlers, but to place by their side-partly to give them a supply of labour at harvest time-unemployed labour, agricultural and artisan, in village settlements. We see in our picture of Cheviot the cottages of these labourers, who, but for this chance, might still be standing eleven or twelve hours in the market-place of the cities, saying, "No man hath hired us."

If a man's family for any reason does not go with him the department makes it part of the contract that it shall retain one half of his wages, which is transmitted by means of postal notes by the paymaster of the works to "the folks at home." In the first six months of its existence three hundred of the unemployed, assisted by the labour bureau, remitted through it to their wives and families no less a sum than $\$ 40,000$.

If no private employer wants his services, the unemployed man in New Zealand can be sent to the state farm 
at Levin to be taught the use of the axe and the spade, and to work co-operatively while waiting for some other employment. There, too, the family is taken with the man. and hundreds of people have found a temporary home, many of them for the first time learning to farm and graduating into excellent workers who have at last secured good places, or who have since taken up land for themselves. The idea of the state farm is that it shall be a "transit station" through which a steady stream of labour, changed from non-effective to effective, should pass.

It was at first attempted to have the elderly men with their families, who have been the principal beneficiaries of the scheme, learn to work together co-operatively, but, I was told by one who knew, "the women spoiled all that."

The experiment of the state farm was handicapped by the very unsuitable character of the land assigned to the Labour Department by the Land Department-almost as if the latter were not in sympathy with the project. Eight hundred acres of heavy forest and scrub is not precisely the kind of paradise one would choose for a fresh start in life for elderly and unskilled men, many of them townsmen.

That the Labour Department has been able to achieve such results as are to be credited to the state farm speaks volumes for the faithfulness and intelligence of its officials, and says no less for the wealth-producing powers of even poor labour on poor land.

The unemployed-there were thirty-seven at the start, with fifty-seven dependents-were put to clearing off timber, working on the co-operative plan and paid full wages. This kept them in good heart, but manifestly made the clearing much more expensive than that done by the private settler, who does not make six or seven shillings a day out of clearing his land. The sales of timber made an important contribution to the expenses of the farm. 
As they felled the timber the men-constantly changing, of course, with new arrivals and departures-went on making fences and roads, and building cottages. The value of the improvements created in this way-by fugitive and inexperienced labour-has come within three thousand pounds of the total cost of the farm to the government, and as land that was worth $\$ 20$ an acre has been made worth $\$ 60$, the experiment has been financially successful, to say nothing of the human salvage.

A considerable part of the men taken in at Levin have been elderly and helpless workmen, for whom private employers and public works offered no opportunity, and its function has been specially benign on that account. To make these men self-supporting is a more skilful and. more useful task than any other a fraternal government could undertake. This state farm holds a necessary place in the political economy of such a country as New Zealand-or any other country.

The important scheme of dealing with the unemployed formulated by the Unemployed Advisory Board of New South Wales, noticed on another page, recommends such a farm as an indispensable part of its plan to educate the outof-works to the point at which they can be made useful in public works and in the settlement of the land. Such an adjunct any thorough governmental plan for dealing with the human detritus of our industrial system must have.

If the Labour Department and the Public Works Department and the private employer have no call for our out-of-work, he has still the Land Department. Minister McKenzie, though a farmer and the representative of a farmers' district, has not limited his sympathies nor his efforts to satisfying the land hunger of the farmers' sons and daughters who, though they had money, could not, under the old squatter régime, get land. Under him the 
village settlements of Rolleston and Ballance have been developed into the "Improved Farm Settlements," which are a more practical and successful contribution to the settlement of the unemployed question than anything to be seen in Australia, Europe or America.

The Improved Farm Settlements are communities built on a foundation of land, labour and co-operation, to give homes and a place in the world to the man who has lost them all in the fierce struggle of modern life, and whose destiny, if unassisted, is to be degraded into a consumer who produces nothing. The Improved Farm Settlement is New Zealand's attempt in the field where most other nations have nothing to show but poorhouses, jails, and potters fields for the "surplus" population. Out of the idle land and idle men the democracy of New Zealand are now at work creating a new type of social and economic organisation. Considering the vital character of the problem of the unemployed and the practically complete failure of every attempt to deal with it elsewhere, this experiment is certainly of fascinating and momentous interest.

There are forty-five of these Improved Farm Settlements in the Wellington, Taranaki, Auckland, Hawkes Bay, Otago, and Southland districts. Most of them are in the North Island, where the unreclaimed public lands are. They cover an area of 73,320 acres. There were on them at the last report $5^{\mathrm{I}} 3$ land holders and 1854 residents. There have been 917 men enlisted in this work, and 364 have left. The settlers had cleared I5, I4I acres of the bush and had grassed 20,8I4. They had been advanced $\$ 286,645$, while the total value of the improvements which had been made by them was $\$ 420,840$, and they have paid in rent and interest $\$ 13,2$ Io yearly.

This result has been achieved by the combination of the waste forests and waste labourers of the community. Using 
the unemployed to make roads is not a new idea, but New Zealand is the only country that has had the wit to see that the tramps could build roads on which the tramp himself could travel to independence. While New Zealand was doing this with its unemployed one of its neighbouring colonies was setting them to scrape paint off park fences.

When an Improved Farm Settlement is to be opened a tract of Crown land is selected which, when cleared, will be suitable for farming, especially for dairying. It is surveyed, roads are laid out, and it is cut up into farms varying from ten to two hundred acres, according to the quality and use. Crown lands only are used for this, not lands which the state has had to buy back. These latter are already improved, and the public could not afford to let them go to settlers who would not know how to make them immediately productive, whereas on forest land their unskilled labour immediately begins to create value.

Maori tribal lands cannot be taken for settlement, but must be bought. However, the Maoris are constantly applying to have their titles registered under the Crown. They thereby get individual ownership, and the government can then take the lands as it is constantly doing. It buys the interest of eight or ten of a tribe and then applies to have this cut out by the land courts, after which it can use it as it chooses. The Maoris are allowed to become settlers in the Improved Farm Settlements, as even a newly landed immigrant could do. "We do not exclude aliens," the officials told me.

The party of unemployed which has been forwarded by the Labour Department is received at the scene of the proposed settlement by an officer of the Land Department. They find there everything needed for shelter and work, and they find the public land in the vicinity surveyed into sections and waiting for occupancy by them. The sec- 
tions are distributed among the applicants by lot. Married men have the preference in the distribution both of work and land. All are immediately set to work to clear away "the bush" and grass their land, so that it may be fit for cropping or pasture. At the same time they are given work on the roads which are to connect their new homes with civilisation, or on some railroad or other public work in the vicinity, and it is arranged that they shall divide their time between their own and the public work. As they clear their lands and get them into grass, money is lent them on the value they thus create, and fifty dollars at least will be advanced to each married man to help him build his home.

"Men absolutely destitute," the Minister of Lands said to me, "in that way become thrifty settlers."

"By this plan," said Premier Seddon, "we at the same time build our highways, and deposit in permanent settlement by their side the labour that builds them."

When I was in New Zealand the Land Department was employing about two thousand men in making roads upon the Crown lands.

Many of the men, of course, abandon their holdings, and these are then usually offered to those of their neighbours who stay. The policy of the department is to allow the successful men to absorb the land of the unsuccessful ones up to a reasonable limit.

While the settlers are struggling they are not asked to pay rent, but when an outlet for their products is secured and they are making a living, the representative of the Land Department in the neighbourhood notifies his superior "that the time has now come when the settlers should be required to pay rent."

Temporary work is also furnished for the unemployed in felling the forests on the public lands; but the practical 
genius of the New Zealander does not believe in temporary remedies, and his main energies have been given to the method by which the unemployed are given work not during the slack season, but for the rest of their lives, if they choose to take advantage of it.

Most of the men who find refuge in the Improved Farm Settlements are of the class of ordinary labourers-"navvies"-but there is among them a sprinkling of skilled labourers and the artisan class. Among the other things done for them is to teach them how to work. The instruction given them is not simply how to work their land, as was shown by a conversation I heard between one of the settlers and the agent of the Land Department. This settler had been a carpenter, and, being rather slow, had found himself always at a disadvantage in the labour market, and had consequently betaken himself to work on the roads and settlement on government land. He had eight children and one hundred acres of land to look after and was doing well with both. When I came to his place he was building a bridge, at his own expense, over the creek in front of his house. He told the official that he and the other settlers in the neighbourhood would get on much better if they could have a creamery. He had written to the Agricultural Department about it, but had received an unfavourable answer.

"Do not rest satisfied with this answer," the official said. "There are different ways of doing these things. If you cannot do anything by correspondence, apply direct to the Premier. Two or three of you go and talk with him at Inglewood, where he is to make a speech in a fortnight. You can do more in twenty minutes' talk than by reams of correspondence."

A creamery would cost about $\$ 8000$. The Department of Agriculture, under the law, is authorised to advance 
funds for the erection of creameries if the settlers can provide their proportion, which, in this case, would have been about \$2500, but the people here could raise only \$1250. There was a discretionary power, however, to make a larger advance, and hence the recommendation to apply to the Premier.

This scene between the official and the settler reminded me of a remark by the Minister of Lands telling why one of his men had been chosen to administer the land laws in his district.

"Because," the Minister said, "he has a human heart and will look out for the settlers, and also has a good head and can protect the interests of the government."

The largest of these Improved Farm Settlements is Whangamomona, in the Taranaki district. The settlements are usually of ten to fifteen sections, or even less, but here about one hundred and eight were offered. Ninety-eight were taken immediately. About fifty of the settlers remain, but some of these are likely to be dropped. Seven years ago this region was an unbroken wilderness. The surveying party had to work its own way through, and had to carry its tents, food, "billies," as the Australasians call the pail they make tea in, and all. Now the traveller goes twenty-five miles by coach, twenty miles more on good roads, and half a dozen miles farther on a bridle path, which is the forerunner of the coach road to follow. He finds flourishing farms all the way. If one was asked to give the age of the settlement from appearances, he would think it to be at least twenty-five years old, instead of seven.

"It is usually the small settlements that succeed. A few men well placed, with land enough near by a population which can give the men work, or near public works-this is the secret of success for this kind of experiment." The erection of a creamery in the neighbourhood almost always 


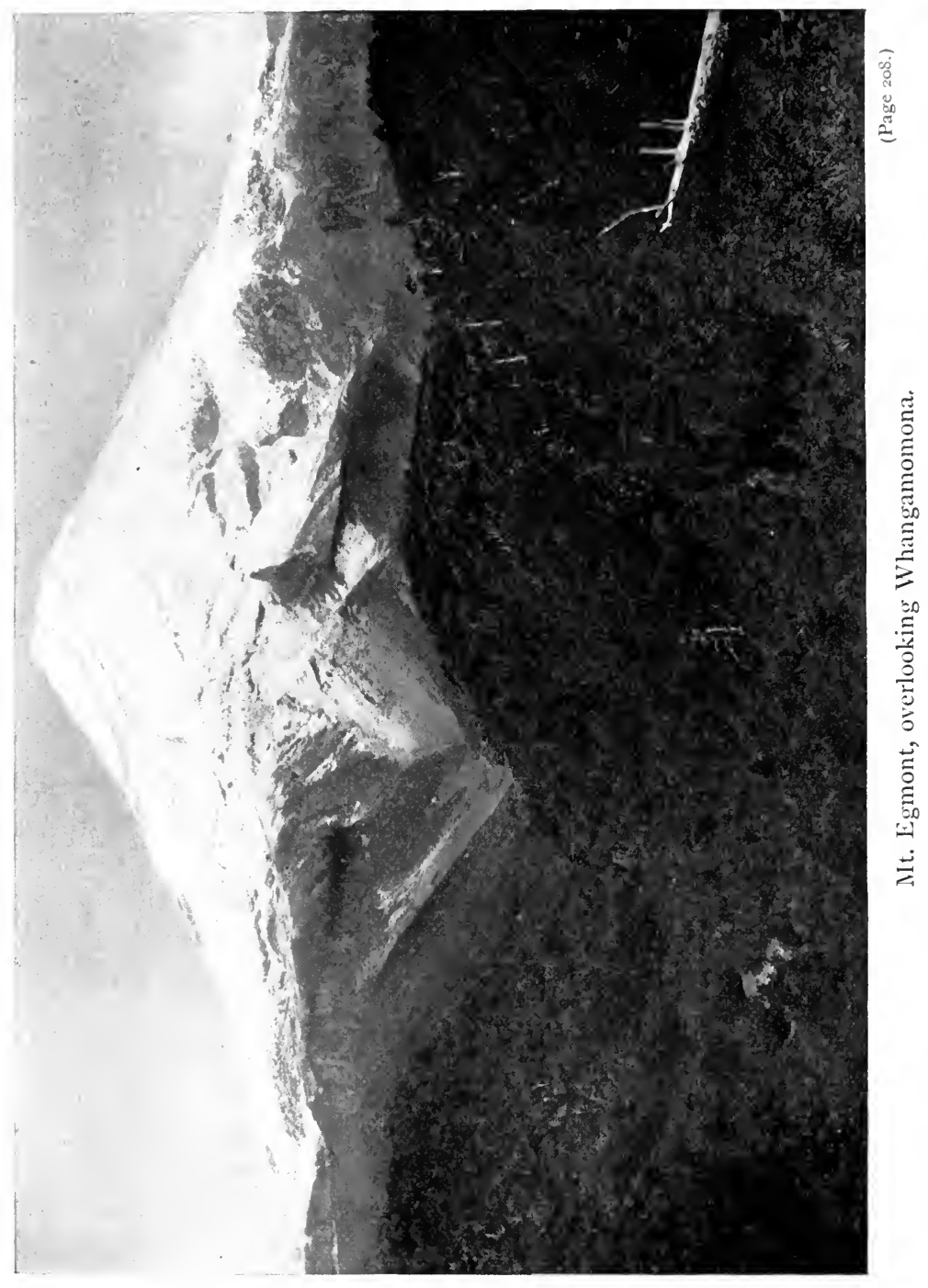



makes success certain, and it is for this reason that money is advanced for them.

The department gives the men whom it thus brings out to put on the land nothing, but it advances them everything except "tucker"-food. They and their families, if these are with them, even find ready for them on the ground of their new start, tents for shelter. These were at first lent, but this it was found made the men careless. Now they must pay a rent which is deducted from their wages. All the tools that they need-slasher, spade, shovel, pickare furnished them, and for these, too, they must pay in the same way. These are all bought by wholesale, and sold to them at only enough of an advance to cover the cost. Hand carts and barrows they are allowed to use free; timber jacks they must pay a shilling a day for; these cost the government $\$ 37$ each.

"Tucker" the men can get on credit if they have a job. The storekeepers are on hand at the monthly payments, and they can always ascertain from the official inspector how much each man is getting. Payments are made at the works, and are in cash. The Land Department at one time proposed to start a store of its own in the vicinity of Whangamomona. It found that the storekeepers were charging extortionate prices for provisions, in consequence of which the men demanded higher pay. Instructions were given to the local officers that unless prices were reduced they should open stores. This was abandoned because it was seen that if this was done it would never be possible, on humanitarian grounds, to refuse food to the wives and children of the men in the settlement, even if they would not work. Such a scheme, moreover, would have been a violation by the government itself of its own truck act, forbidding payment in kind.

One of the most important things which is taught the. 
men is to work co-operatively, as has been described in the chapter, "The Workmen are the Contractors." Instead of a contractor there is the public engineer, who lays out the work and makes contracts with each group of men to do such work as they bid for. "With the exception of a few special items," the land report for I899 says, "all the work done by the department has been on the co-operative system."

When a "co-operative gang" has been formed by the men-it must consist of four, but there may be as many more as the men wish-they then choose their head man. He represents them in the contract made with the department. The money due each month, called "progress money," is paid to him, but in the presence of the others. The statement issued to the head man gives all the items, deductions and the like, and any member of the gang can see it. The men can change their head man at any time they desire to do so. It is very seldom, I learned, that any four men come together again after having once worked with each other.

When the men first come from the cities to this rural life they show their inexperience and irresponsibility in curious ways. It was found from the storekeepers in one of the settlements I visited that the settlers when they first came spent from five dollars and upward a week for "tucker," buying all kinds of fancy goods, like sardines, where the ordinary workman spends only half that amount. This exuberance soon wears off. Getting their gardens makes a great difference. "Our potatoes, carrots, parsnips, and other truck make a difference of one half in our flour bill," one of the settlers told me.

The Whangamomona settlement, through which I rode for two days, is a very picturesque illustration of the land settlements of this type. Two thousand acres are reserved 
here to preserve the beauty of the road. This has been built entirely by the labour of the men who have been brought from Wellington, Christchurch, Napier and other towns, and is a fine specimen of mountain engineering, and a link in the main highway on the west side of the North Island. The settlement is three years old. The gardens, the galvanised iron- "tin"-houses, the wooden chimneys built outside, the cows feeding in pastures blackened with the stumps of the timber felled and burned, the doorways filled with groups of children growing within as luxuriantly as the flowers and vines without, make a landscape which may have too many sharp edges and colours too incongruous to delight the eye of the landscape painter, but it is a picture any statesman might be proud to sign his name to.

Every home here is an adventure-the goal of a Pilgrim's Progress, very prosaic no doubt, but thrilling enough to the men and women and children who have been enabled to shut these doors against the city wolves of want. One of the cottages here is the castle of a man who had been a day labourer in Christchurch. He began by working on the road, then opened a boarding-house. He had one hundred acres. Among other products is a house full of children.

Not far away lives another "successful man," who was a day labourer out of work. Given this chance, he saved money, bought cows and made butter to sell to the other workingmen.

Yonder is the house of an Irish baronet. He has come in here, taken up land, and gone to work like any day labourer, and is doing better than the average.

Occasionally some abandoned house tells of a man who has given up the struggle.

Here is a gas stoker from Napier, who, when he lost his job, went to the Land Department for a life position 
as one of its tenants. He has sixty acres, and his house is a bower of roses and babies. In the garden is a new Russian forage plant that grows as a tree, with which he is experimenting. The mother points with joy to the little four-year-old, who, when eighteen months old in town, could not walk, but is now running everywhere.

"We cannot expect to get much out of it for ourselves," she says, "but we will make the children, we hope, independent."

Not far away is the place of one who was an ordinary wood cutter, who is now living on twenty acres of his own, in a house which the Land Department helped him to build by advancing him $\$ 75$. The men take great pride in their new homes, and many of them travel every day miles on horseback to get work to keep them going, if no work is to be had near by.

In a house which I asked permission to photograph there was a window not glazed. "Take it so as not to show the window with the canvas cover," the owner pleaded. This man was discussing with the government officer, Mr. G. F. Robinson, with a record of nearly thirty years' service, the disposition of the section adjoining his.

"I hope Lockwood will get it," he said. "He has a lot of children. We have nine children of school age in the settlement now, but no school. This little settlement was at the extreme end of the bridle path into which the coach road and the waggon road had dwindled, as we penetrated farther and farther into the wilderness. As soon as possible a school will be established here, for the democracy follows the settlers close with the schoolhouse, although the pay of the schoolmaster is not very large-in one settlement $\$ 7.50$ a week. In New Zealand primary education is free, universal, secular and compulsory, and thirteen fourteenths of the children are educated by the state. In the 
Whangamomona settlement I saw ten children going to school on four horses, and sometimes there are four to be seen on one horse. We saw three little ones who had to walk six miles every day.

Each family has its separate home. The co-operation is in the work, not the living. The preference always shown for married settlers in giving out road and other work is really a preference for children. One of the reasons urged for the resumption of the large estates when that measure was in Parliament was that it would help young people to marry. The political economy of New Zealand takes large account of the baby crop. Single men are forced out of the settlements rigorously if they do not comply to the letter with all the regulations. For instance, settlers must make improvements in proportion to the money paid them for public works. Single men are required to improve to the extent of one half of the wages they receive, but married men to the extent of only one third. The enforcement of this rule is strict and drives out the undesirable single men.

This settlement, like most of the Improved Farm Settlements, shows a decrease in the number of persons living on it, but an increase in the work done and the value of the improvements. In other words, the natural and official weeding-out process is making itself felt. The men who are unfit or unwilling are leaving, but those who remain are working so faithfully that the wealth of the little community is increasing faster than the number of inhabitants declines.

In 1898 there were 187 persons on the land in Whangamomona; in 1899,168 , but the number of cattle, horses and sheep has increased from 887 to II 78 and the value of the houses, gardens, etc., has grown from $\$ \mathrm{II}, 095$ to $\$ 20$,245. The number of acres under grass is 3052 against 2202 the year before. The official report says: 
"The settlement may now be said to be permanently established. A large school has been erected and opened. A dairy factory"-the one as to which we overheard the Land Department officer giving advice to one of the settlers- "is in contemplation, and most of those settlers who now hold land will, in all probability, remain and become good settlers."

There are six Improved Farm Settlements near Auckland, three to the north and three to the south, sheltering about sixty families. In this district work and land have been given only to married men. So far at least eighty per cent. of the men have proved permanent. The settlements were fortunate in their proximity to saw-mills, kauri forests and other sources of employment. The advance of money to men here to build with has been discontinued because it was found that some borrowed and built only to get work, and then cleared out.

When there was no road work to be had the Land Department helped these men out by allowing them to fell kauri trees on their own sections and on Crown lands by payment of a royalty. The timber was felled by co-operative gangs working together, and only resident settlers were employed at this work, so that the money earned might be kept amongst them. For the settlers physically incapable of the severe labour required in felling kauri road work was provided, if possible.

At Mangatu, Auckland North, the ten original settlers are still resident, and with their families number seventythree souls. They have been advanced $\$ 7165$, and this has enabled them to make the improvements worth $\$$ I 3, I I 5 .

At Uruti, in the Taranaki district, out of seven settlers four remain. There are twenty-two persons on the land, and with them are one hundred and forty-three cattle, twenty-six sheep and four horses. These four men obtain work 


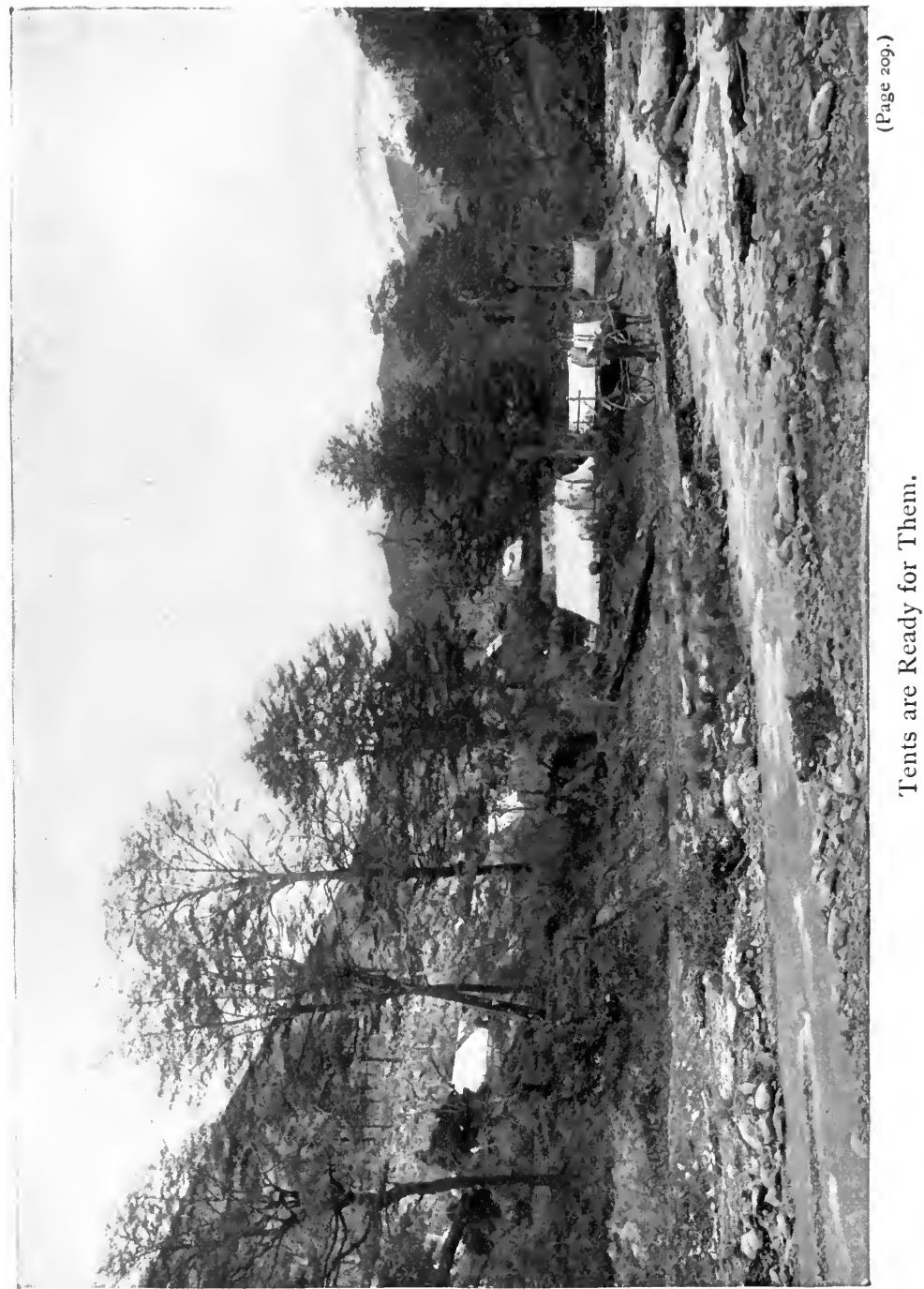



enough from the local authorities and farmers with large holdings near by to be able to dispense with any necessity for further assistance. They have cleared and grassed five hundred and two acres. They have a post-office, a school is soon to be erected, and a dairy factory will be established.

Nihoniho, in the same district, is an instance of a settlement pushed too far ahead of the opportunities for employment by its members. The soil is very good, but the lands around it are not yet open. As soon as the road work in their immediate vicinity was completed the selectors, with the exception of three, abandoned the district.

Akitio, in the Wellington district, contains 3300 acres, held by 32 settlers, with 66 persons to be supported by them. Twenty-three of the settlers are employed on the roads near by, two work at saw-mills, three find work to do on their own holdings. By energy, industry and economy many who started without means, depending on road-making and Treasury assistance in clearing and other improvements, are now comfortably housed, have part of their sections cleared, grassed and stocked, and in a few years' time, when the road work is completed, will have their holdings in such a forward state as will enable them to get a comfortable living without having to depend on outside work.

The three settlements of Ngaire, Poti and Maata, in the Taranaki district, are well established, the settlers have paid up most of their rent and are now practically beyond the need of assistance.

At Mangaere, which we passed through on our way to Whangamomona, an ordinary bushman was living on twenty acres, in a house on which the government had advanced him seventy-five dollars as soon as it was finished. All the men in this settlement have been advanced money on their houses and work in sums ranging from $\$ 50$ to $\$ 100$.

Ten persons here have made improvements of $\$ 5200$. 
The only rent in arrears is $\$ 4$ due from one man. The future of this settlement is assured by a creamery which was erected in 1899 .

One of the twelve settlers at Kawatau died during the year I899, leaving his widow in possession of his section. The only public expenditure during the year was incurred for grass seed and sowing eight acres of land for this widow.

There are kickers and grumblers of course. One very intense specimen of this type whom I met indulged himself out of pique with his own government in an enthusiastic advocacy of the superior virtues of everything in America. He read me, with much gusto, in the presence of an official of the Land Department, an article which he had published in the local paper.

"In this district," his article ran, "the farmer makes the road to his farm with an American pick and shovel, he puts in his wheat with an American drill, he reaps it with an American reaper and binder, he pumps the water for his harvest hands through an American pump, he takes his wheat to a mill where the most intricate machinery is American, he drives around town in a buggy that is mostly American, his timber is cut with an American axe, the hammer that drove the nails in his house was an American hammer, his saw was American, and, finally, his wheat rolls into Wellington behind an American locomotive."

This man's denunciation of the land policy was most vindictive, but it had its origin in the enforcement of a necessary regulation. He wanted to graze other men's cattle on his land. The land board told him that he could do so, but that he must pay the receipts over to it. In the same way, if he sold timber from the section he would have to turn the money into the treasury of the land board, for the obvious reason that the treasury was' lending him money on the security of this timber and grass. 
This grumbler had been one of those with no money, no land, no work. His fellow-citizens gave him a chance to get all these and he had got them, but apparently he reciprocated none of the kind interest in the welfare of the others which lay at the bottom of the scheme of settlement, which was making a man of him. Had he been a member of a co-operative society which did these things for him-that is, if he had done them for himself in a nearer and more realisable way than doing it for himself through the state, he might perhaps have appreciated it.

There is a more needy class even than the navvies and out-of-works who get the most of the benefit of the Improved Farm Settlements. This more necessitous class is the unemployed tradesmen, mechanics, clerks, and the like. For them some form of co-operative settlement is being urged, and, in connection with that, some organised system of instruction such as is proposed by the Unemployed Advisory Board of New South Wales, as noted on a following page. What this class can do, however, even under the present system, is shown by the experience of two printers of which I learned in Auckland. When the linotype was rising on the horizon of the compositors, the member of the upper house of Parliament for that district, the Honourable W. T. Jennings, at a meeting of the Typographical Union. pointed out how great a mistake it would be for the men who were certain to be thrown out to hang about the cities. They had on the average about $\$ 500$ of savings. The trade-union would allow each man displaced about $\$ 75$ more. The "Herald" of Auckland agreed to add something to this. Their savings and this assistance, if they stayed in town, it was pointed out to them, would melt away, and at the end of the year they would be penniless and with no prospect of any future help. Their representative in Parliament advised them to go into one of the 
village settlements. He promised that he would use his influence to have good land assigned them by the Land Department. He offered to go himself into this new settlement life with them. But he could not raise the least interest in his suggestion. One or two said it would be a good thing, but made no move.

The event has been just as he anticipated. The men who have been displaced by the typesetting machine are drifting up one street and down another. There is no possibility of their getting work at their own trade, and they have exhausted all the help they received.

Meanwhile two of the brightest young men among them, who saw what was coming, went into the country, and have had a very different experience. Getting some public land, they put what money they had into stock, tools and their maintenance. They had a very rough time, but at last are getting their feet firmly planted on the ground, and the ground is their own. While the other men go on rotting, these men will be growing more independent, and will be raising children and strengthening the state along with themselves.

This success is something like that which has been achieved by purely voluntary effort on "Printers' Farm," which has been established by the "Big Six" Typographical Union of New York. This union, foreseeing what was coming in the introduction of the typesetting machine, bought one hundred and sixty acres a mile south of Bound Brook, New Jersey, and there, on some of the richest soil in New Jersey, under the Watchung Mountains, in a scene rich with revolutionary associations, is a colony of fortyseven men-printers who have made themselves farmers.

These Improved Farm Settlements are, as we have shown, not all successful. Some mistakes have been made, but the fact that the population is holding its own and that 
improvements are increasing shows that the system is taking root. ${ }^{1}$ The numbers may seem small to those whose imaginations have become imperial. Two thousand and ninety-three men settled on the land, they and their dependents, numbering 6509, may not seem very much, but the significance of the plan does not lie in the numbers already relieved, though these speak eloquently, but in the fact that a working plan has at length been devised and put into successful operation which can be expanded to meet any of the demands of the problem. No other country has done

1 Adding to the results of the Improved Farm Settlements those of the Village Settlement system, also mainly for the benefit of the unemployed, we have the following particulars of what has been accomplished by New Zealand in its attempt to convert idle land and idle men into sources of social and financial strength for the country.

COMPARATIVE STATEMENT SHOWING POSITION IN 1899

OF IMPROVED FARM SETTLEMENTS AND VILLAGE HOMESTEAD SETTLEMENTS.

\begin{tabular}{|c|c|c|c|}
\hline Particulars. & $\begin{array}{l}\text { Improved Farm } \\
\text { Settlements. }\end{array}$ & $\begin{array}{l}\text { Village Homestead } \\
\text { Settlements. }\end{array}$ & Totals. \\
\hline Number of Settlements, & 45 & 165 & 210 \\
\hline Area, & 73,655 acres & 35.454 acres & 109,109 \\
\hline New Selectors during 1899 , & 78 & IOI & 179 \\
\hline Forfeitures and Surrenders, & 164 & 62 & 226 \\
\hline Total number of Selectors, & 526 & 1,567 & 2,093 \\
\hline $\left.\begin{array}{c}\text { Total number of persons } \\
\text { on the land, }\end{array}\right\}$ & 1,615 & 4,894 & 6,509 \\
\hline Total amount advanced, $\{\underset{\text { Bush }}{\mathrm{I}}$ & $\begin{array}{l}\text { Houses } £ 4,511 \\
\text { a felling } £ 41,741\end{array}$ & $\begin{array}{l}\text { Houses } £^{13} 3,76_{9} \\
\text { Bush felling } £^{12,165}\end{array}$ & $\begin{array}{l}£ 18,280 \\
£ 53,906\end{array}$ \\
\hline $\left.\begin{array}{c}\text { Rent and Interest paid } \\
\text { during year, }\end{array}\right\}$ & $£ 711$ & $£ 4,877$ & $£ 5,588$ \\
\hline $\left.\begin{array}{c}\text { Rent and Interest paid from } \\
\text { commencement of system, }\end{array}\right\}$ & $E^{1,064}$ & $£ 31,873$ & $£ 32,937$ \\
\hline Improvements, & $£^{64,988}$ & $\ell^{115}, 834$ & $£^{180,822}$ \\
\hline
\end{tabular}

The Treasury has advanced $\$ 360,930, \$ 169,685$ have been received in rent and interest, and the improvements amount to more than twice as much as the loans, $\$ 904,110-$ a pretty good investment financially, to say nothing of the far more important interests involved. 
this with the unemployed. There are many plans for the relief of this unfortunate class. Here is what is wanted however-a plan not to relieve but to rehabilitate, to restore them to their economic and other citizenship.

Co-operative labour colonies for the unemployed have never been favoured in New Zealand. Though the New Zealanders speak of themselves as "experimenters," I observed that they keep well within the practical in their ventures. This is probably the reason for the success they have had. Plans for such settlements are urged in New Zealand, as everywhere, by those who seek a short road to the co-operative commonwealth. In several of the Australian colonies some very ambitious attempts have been made to realise the hopes entertained that the unemployed could thus be organised in a new fashion into prosperous economic and civil life. But the New Zealand Minister of Lands believes these colonies to be impracticable at present, and "I believe in the practical," he says.

Michael Davitt, in his charming and valuable book, "Life and Progress in Australasia," describes graphically the cooperative communities and socialistic settlements which were established by the South Australian government after the panic of I 893. A great deal of time and energy, public and private, have been spent on these settlements. When Davitt was there the prospects were of the brightest, and it was with keen interest that I inquired about them when I arrived in South Australia. Social alarm, "the terror," had a place among the reasons which led to their establishment. The reaction of 1893 was extremely severe throughout Australia. There had been several bad years of drouth to add their losses to those of the panic. A building boom had collapsed, and the unemployed were parading the streets of Adelaide with black flags, holding revolutionary meetings, sleeping by thousands in the parks, and demanding bread 
and work. All the materials for a great riot were ready. It was under this pressure that the people and the officials acted, the latter none too willingly.

When Norway sent to see if land could be had in South Australia for settlement for Norwegians out of work the government had replied there was none. It said now to the citizens who proposed the co-operative experiments that there was no land available. But, it added, if you can find land we will let you have it. Thereupon three men, representing the workingmen-one of them a clerk, another a blacksmith, and the third a roustabout-went on an exploring expedition to see if land could be found. The River Murray which flows through an alluvial valley, had hitherto been used only for sheep. The "squatters" living there declared that it was good for sheep only, but the workingmen believed that they could make something of it agriculturally, although they recognised the difficulties that were involved in the fact that cultivation was possible only with the help of irrigation, which was laborious, slow and costly.

The first Murray River settlement was located at a place called Lyrup. The state, besides alloting land, advanced tools, shelter, subsistence. The law under which the settlements were made had been so framed that the people could organise their communities as they chose-individualistically, co-operatively, communistically.

"There was a wave of communistic feeling at that time all through Australia," one of the men prominent in this work said to me, "and this made itself felt in the organisation of these colonies, which at the start were all co-operative and some of them communistic."

Murtho was one of these communistic settlements, but the communistic features were dropped in three weeks, and by this time the co-operative and communistic features have been practically abandoned in all the settlements. 
By the original act the Treasury advanced only fifty per cent. of the cost of the experiments, and the men were entirely free to manage their own affairs; but the colony was induced to go in deeper, and has now an indebtedness charged against the settlements of about $\$ 500,000$. This mistake, which, it will be observed, is quite different from the New Zealand method, has led to another. The government, to secure itself for the debt, has taken in charge the selling of the produce of the colonies, and the buying of their supplies. The colonists are now obliged to turn over everything to it. It has "degraded them," as one of its own officers phrased it. It is admitted on all hands that the men work hard, but, work as hard as they will, they see little prospect of getting ahead of their indebtedness. They are allowed to handle no money, except a few pounds which they are allowed out of their earnings, almost as if it were a gratuity. They are paid wages for their work, but not in money. They are given fifteen shillings a week for subsistence, to be taken out of the stores. Whatever they earn in excess of fifteen shillings-and many earn thirty shillings a week-is credited them as a fund out of which they can draw for extras, like implements, houses, extensions, etc.

The experience of the settlers of Moorook may be taken as a fair illustration of the results of this method of state installation of co-operative village life. The settlers at Moorook, like all in these River Murray settlements, were labourers taken out of the streets and given but little more direction than they could find within themselves. Still, with all these disadvantages they made a success, so far as proving that the land they had chosen was fit for agriculture-indeed, with proper irrigation, admirably adapted both for grain and fruit. There were, of course, many internal difficulties associated with this attempt of 
strangers and men without practical knowledge of previous co-operative experience to organise co-operative life, but all the best observers of the movement believe that they would have succeeded had it not been for the disastrous features of state interference.

"We all knew the government could establish successful beggar colonies," said one of the members of the South Australian Parliament, "outdoor poorhouses, but here was an attempt to place the unemployed on the land and make permanent settlers of them on co-operative lines. It was the most advanced experiment in the world. In many cases these settlers proved themselves more skilful even than the experts who were sent to direct them."

The settlement at Moorook had just broken up when I reached Adelaide. The Minister of Lands had a short time before interfered and said the settlers must leave their earnings with the department. The men pointed out that they could not buy to as good advantage through it as by themselves, for the dealers who sold to them through the Minister would charge them prices so high that they could not live. In the case of some of the adjoining settlements the members had not proved themselves to be particularly steady men, and to hold their money might perhaps have been helpful, as it made it impossible for them to throw it away. But in the case of Moorook it was fatal. The men there were trusty, and were too independent to submit to such interference. Nine out of thirteen left. They and their friends urged that a different ruling be made in their case from that applied to the other settlements, but fruitlessly. The Minister, acting on the merely financial aspects of the matter, and seeing that the men were spending more than they were receiving, insisted that they could not continue "on their own," as the Australian phrase is. Thereupon they gave up their land, and thousands of bushels of 
onions, potatoes, and other produce which they had raised were left rotting on the ground.

This result is what any co-operative adviser familiar with the causes of success and failure in co-operation elsewhere would have predicted as inevitable the moment the officials began to take charge of the sales and purchases of the men. It is an illustration, however, of the cheapness of co-operative living, of the productiveness of co-operative methods, and the wealth that lies awaiting the union of labour and land, that, with all these vicissitudes and mistakes, these settlements have already resulted in an unquestionable economic gain to the colony.

The report of the surveyor-general for 1898 reports satisfactory progress. The total area under cultivation in all the settlements had been increased from 4829 to 6585 acres, and the total value of the improvements is $\$ 323,840$, and he sees "no reason why the settlements should not be a decided success."

But they are no longer illustrations of the co-operative idea they were founded to vindicate. The strong men are shouldering out the weak ones, with the idea of absorbing all that has been done. At Pyap I learned the members are charging a premium to any new member, unless he is an artisan, like a carpenter or blacksmith, for whom they have a great need.

"The settlements will die one after another," an official of the Land Department said to me. "The land will be offered for lease to whoever best shows his ability to pay a fair interest on the cost of the improvements."

One service which it is recognised that all these efforts of the workingmen and their friends have done the community is that they have practically added a new territory to the colony. "Upward of eighty thousand acres of Murray River land," says Premier Kingston, "that were never put 
to use before have been taken up by farmers since the establishment of the settlements, owing to what the settlers have done in the way of proving the possibilities of the district."

The Premier repelled the criticisms that too much had been done to help the unemployed establish themselves, their wives and children in homes on the banks of the Murray.

"We did not extend to them one half the concessions," he said, "which have been extended at different times, and justly extended, to more powerful and influential classes who did not stand so much in need of it."

"The village settlements are doing well enough," the Premier said to me, but in saying this, of course, he referred simply to the material results. These settlements can no longer serve as illustrations of what men can do in cooperative or communal life.

But even the broken bits of this co-operative experiment arrange themselves in the kaleidoscope so as to re-enforce all previous experience of the extraordinary wealth-producing power of co-operative effort. In fact, the greatest difficulty with co-operation is not that it does not produce wealth fast enough, but that it produces it too fast. Co-operative and communistic societies do not stay poor long enough to give their members a chance to grow together.

This bit of verse which is floating about South Australia shows that some one has been able to get a laugh out of the serious side of these efforts :

\section{THE SETTLER'S ELYSIUM}

"A village settler's is the life for me, If it is all that it's cracked up to be. I want a place where corn, and wine, and hoil Is bustin' up promiscuous from the soil; Where hens and turkeys run about in freedom, And no one ain't a-troubled for to feed 'em; 
Where cows produces butter, milk, and cheese,

Just all according to the teat you squeeze;

Where calves are never born, but only oxes,

And fruit grows dried and packed in little boxes;

Where 'all-wool goods' straight from the sheep is taken,

And rashers planted springs up 'ams and bacon;

A place of calm delight and innocence,

Where everything but labour is intense;

Where Gov'ment spends all that must be spent,

And at the proper time remits the rent,

And follerin' out the principles as we hold,

Finally gives a man his little freehold.

A spot where all is pleasant, nothin' rilin',

Just like a poetry village, allus 'smilin' ';

A sort of half-way station to the skies,

A workman's genooine, earthly paradise.

If this will stop the country goin' to pot,

Send me, I am a hardent patriot!"

New South Wales also tried co-operative colonies after the panic of I893. The unemployed, enlisted from the streets indiscriminately, were sent out to live together and work together on new land, in the belief that their poverty would be bond enough to hold them together. Any one who knows the infinite patience and almost infinite failures by which alone the co-operators of England, France and Germany, though men of the same trades and nationality, have been able to build co-operation to the magnificent thing it is now, would know what must be the end of such a venture.

Just before I reached Sydney the Minister of Lands, under whose charge these co-operative settlements were, had issued an order discontinuing the co-operative feature. Of course this put an end at once to that side of the settlement life which was alone of any unique interest. As in South 
Australia, these settlements, though failing co-operatively, have not failed financially.

The whole story was told me in Sydney of the causes of failure on the co-operative side: the jealousies of the men, the incompetence of many of them, the poor soil mistakenly chosen on "expert advice," the grudgingness of the disbursement of the money by the Treasury to the settlers, the active and passive opposition of the officials, the illegal and certainly impolitic and unjust expulsion by the department of the single men who were doing the most unselfish work of all, as they, with no families, shared with the married men; the resignation in a body of the citizens' committee in charge of the settlements, as they could get neither hearing nor help from the Minister of Lands; and finally the order discontinuing the co-operative régime altogether, and dropping the settlements to the level of the ordinary individualistic life of the outside world.

Government endowment of co-operative settlements proved as disastrous as private endowment of co-operation has always done. Every one of the co-operative societies so generously endowed by the Christian Socialists of England, in the time of E. Van Sittart Neale, failed. The result of this method of establishing co-operation is pithily summed up in the phrase current among English co-operators that "to subsidise co-operation is to kill it." The most that the political or private friends of co-operative effort can do is to teach it.

The Schultze-Delitsch and Raffeisen banks, which have spread all over continental Europe during this generation, would not have outlived the nursing bottle if SchultzeDelitsch and Raffeisen had loaned the people the capital to start with. It is by keeping close within the lines of this policy - to teach co-operation, never to endow it-that the Honourable Horace Plunkett has been able to achieve his 
remarkable work in the creation of a new industrial life in Ireland. Co-operation was made a living thing in the economic system of the colonies of New Zealand and Victoria and Canada, because the government taught the farmers how to co-operate, but left them to do the co-operating themselves at their own expense.

The most thorough plan having any official character which has yet been promulgated for the radical treatment of the unemployed question in Australia comes from the colony of New South Wales. As the result of the failure of the cooperative villages we have mentioned and to provide for a social evil which it is recognised is chronic in our modern civilisation, New South Wales appointed last year a board called the Unemployed Advisory Board. This is to advise what permanent policy to adopt, and to carry out such of its recommendations as may be accepted by Parliament and the public. It consists of three ministers of the Crown and nine other members, including representatives of the unemployed, members of Parliament and labour organisations, and some of the best known clergymen and other citizens. It is given "power to carry out the work, subject in all respects to the approval of the Governor-in-Council."

This board made its report in September, I899. Its recommendations, based, as they are, on the recent experience of New South Wales itself and the other colonies, and made in full view of what has been done everywhere else, especially in New Zealand, certainly have the importance of news of a high sociological value to statesmen and reformers the world over.

It proposes, first, an extensive scheme of "reproductive public works"-reproductive, it will be observed, not of the kind seen in 1895, in Sydney, when thousands of men were scraping the paint off the fences or hauling sand from one place to mother in the public parks and back again, just to 
"make work." Those public works are to be managed on the co-operative system adopted in New Zealand, which the board says has "had highly satisfactory results, both to the men employed and to the government."

The programme of the board includes such enterprises as planting the public lands with trees, clearing and draining them for settlement, the storage and supply of water for mining, building bridges, making railroads, highways, and tram lines, which, in New South Wales, are owned by the national government, all of which, if properly managed, would add more than their cost to the value of the property of the people.

The board further recommends :

First. A National Intelligence Department for men and women.

Second. Labour depots where the unemployed can be temporarily shelterd and employed.

Third. Industrial Farm Settlements-an expansion of the labour depot-where the men are given work and technical instruction, and are sifted out into incapable and capable.

Fourth. Assisted Settlement Blocks, where the men who graduate from the Industrial Farm Settlements are given farms of their own.

Fifth. Compulsory Labour Farms for the vagrants.

In addition to this, the board proposes subsidies to the prospectors- "fossickers"-in mineral fields; systematic employment for the men in the public institutions who may be found fit for such effort, calculated to be half the total number of inmates; advances to settlers to prevent their ruin at the hands of the usurer, who is a constant source of supply of unemployed; allotment of land to societies formed to settle co-operatively; treasury advances for the establishment of co-operative industries in the Assisted Set- 
tlement Blocks; and, finally, and not the least important, instruction in agriculture for all the primary schools in the colony.

The board ascertained by their inquiries among the inmates of the various charitable institutions of the colony that a very large majority-eighty-seven per cent.-of the workingmen who had had to seek help were unskilled labourers, who had never had any sort of technical education, skilled training or instruction in any trade or calling. Of the skilled workmen a very small proportion were paupers. It was this striking illustration of the value of technical training that led the board to urge the "desirability of extending a system of agricultural instruction to our primary schools. In view of our belief that to a large extent the land offers the best means of permanently solving the unemployed question, we consider the sooner that attention is given to the instruction offered youth in using the land to the best advantage, the more success will attend the efforts in the direction of agricultural pursuits."

The board recommends the compulsory resumption by the state of drainable areas, suitable for agriculture, which have been neglected by the private owners.

The labour depot proposed by the Unemployed Advisory Board of New South Wales resembles the state farm which the New Zealand government has established at Levin. The colony of Victoria has also something like the labour depot in a state farm at Leongatha. This is founded on the plan of the well-known German labour colonies. It contains 800 acres, admirably equipped with buildings and agricultural machinery of the best type. The smallest number of men who have been there at one time is forty-seven, the largest 346. When I was in Victoria the number being entertained was 150 , an increase due to the return of miners from the gold fields of West Australia. The average stay 
of the men is three months. Sixty per cent. of them, I was told by Colonel Goldstein, who is in charge of the farm, were drunkards. No one over fifty-five years old is received. Victoria at one time established a few settlements for the unemployed, and made some advances of money, but this has now been discontinued.

The most important function of the Industrial Farm Settlements thus proposed in New South Wales is to do all the preliminary work of clearing, road making, building, etc., to prepare for use the land which is to be made into the Assisted Settlement Blocks. The pay of the Industrial Farm settlers is not given them in money, but in the form of board, residence, clothing, etc., in proportion to the work they do. These Assisted Settlement Blocks are not to be sold, but rented. The rent is to be two and one half per cent. on the unimproved value of the land. No rent is to be paid for the first two years. All the improvements which have been put upon the land by the state in the way of clearing, etc., are made a charge on the land and are paid for by the tenant in annual instalments extending over a period of twenty years, with interest at the rate of four per cent. on the unpaid balance.

The report does not emphasise it, but it is to be taken for granted that, as is done in New Zealand wherever possible, the public works and the settlement of the land shall be made to go hand in hand-the labour that builds the highways, railroads, bridges, settling down on the land alongside; the wages the government pays the workingmen enabling them to become permanent contributors to the revenue of the railroads and public buildings they have erected. In this policy and not in the subsidisation of industry will be found the key-note of successful statesmanship in dealing with the problem of the unemployed.

Since these plans of the Unemployed Advisory Board 
were made and submitted there has been a change of ministry in New South Wales. The new government has appointed a commission to carry out the proposals, but, singularly enough, has put upon it only one member of the board which prepared them. "It is a great pity," one of the board writes, "that those who conceived these plans should not have been allowed to take part in executing them." 


\section{CHAPTER $\mathrm{X}$}

\section{A COUNTRY WITHOUT STRIKES}

All the Australasian colonies have labour parties more or less strong, generally less, and labour legislation more or less advanced, generally less. Only two colonies have anything to show that could be called novelties in this fieldVictoria and New Zealand. Australasia is commonly spoken of as if it were run by the workingmen, and run hard. But the least observing traveller finds at once that nothing could be further from the truth than that the workingman is the master anywhere in Australia or New Zealand. These are not labour countries, and their advanced institutions are not due to labour parties. While I was in Melbourne the trades-unions were refused permission by the mayor to parade the streets in the celebration of their eighthours holiday. The best they could get was the lefthanded intimation that if they "strolled" through the streets they would not be molested. The year before the mayor had declined to allow a room in the town-hall to be used for a meeting of citizens investigating the unemployed question. In Melbourne the workingman has an almost magnificent trades hall, as a monument of former grandeur, covering a large area, with a fine and expensive building, but everywhere now about it are evidences of discouragement and decay. The fact is that nowhere in Australasia have the workingmen recovered from the effects of their crushing defeat in the strike of 1890 . In New Zealand the 
people, including the workingmen, turned this defeat into a victory by making it the occasion of a renaissance of reform which it has been the province of this book to chronicle, but no equally fortunate issue followed in the other colonies. The impulse was felt in New South Wales and elsewhere in Australia, but it reached only a scanty realisation.

The workingmen have not yet been able to establish the eight-hours day by law in any colony, and have to content themselves with the general observance maintained by the best trades-unions by the simple strength of organisation. Within these limits the institution is firmly established. I was informed by the officials of the Public Works Department in New South Wales that it was not necessary in making out specifications for contractors to stipulate for the eight-hours day, as its observance was a matter of course in the building trades. The interest of the workingmen demand universal observance of the eight-hours day, but the law by which alone this could be had the labour parties have nowhere been strong enough to get enacted. Nowhere, either in Australia or New Zealand, is there a labour party which has ever had a majority in Parliament, and no labour party has ever been able, by the most skilful tactics, either of fusion or independence or the "squeezing policy"-supporting either party in return for concessions-to hold the balance of power for more than a moment, or, during that moment, to secure any really radical legislation. Even in New Zealand the initiative in its industrial legislation, which is minute and advanced, is not to be credited to a labour party.

It is in New South Wales that the most promising political organisation of the workingmen has been developed. In 189 I the workingmen of that colony elected thirty-five out-and-out labour representatives to the new Parliament containing one hundred and forty-one members. The ap- 
pearance of a distinct labour party so strong in numbers and strong, too, in character and intelligence, was an event attracting attention all over the world. There were great expectations in Australia and abroad of the reforms which would follow, but the new party was split at the very opening of its career. Its opponents cunningly introduced a question involving the venerable issue of free trade and protection, and a quarter of the labour members deserted their party and supported the ministry, as it supported the tariff. The other labour members were of shrewder stuff and voted with one party for protection, to get the electoral reform of "one man, one vote," and voted with another party for free trade to get the land-tax.

The labour party of New South Wales still survives. Its manifesto of 1898 shows a membership in Parliament of nineteen. It has done good work and has been instrumental in overturning several ministries, as that of Sir Henry Parkes of 1892 and the Reid ministry of 1899 . Its influence was important in such legislation as the reform of the suffrage, the abolition of the contractor in many government works, and numerous improvements in land and labour legislation, but it cannot be said to have added any such notable things to the list of realised radicalism as New Zealand has done.

That the labour members have used their Parliamentary power with great conservatism is sufficiently plain. "The ministry of 1899," I was assured by one of the labour members of New South Wales, "is absolutely dependent on the labour vote." But with this supremacy the labour men have made no demands that could be called radical. The labour party of New South Wales is known as the Political Labour League, and puts forth two platforms. One is called the "fighting platform," and the other is the "platform." The "platform" contains the whole list of the social de- 
mands which the workingmen would like to see established by political means, and includes such things as free medical services for every one and the nationalisation of mines, land, banks and railroads. In fact, it adopts the phrase of the German Socialist Labour Party and calls for nationalisation of "the means of production, distribution and exchange." The "fighting platform" puts forward only those things which it is proposed to make immediate issues. The "fighting platform" of 1898 , for instance, mentions only one of the radical issues just quoted from the "platform." It puts forward as the first matters to be pushed through Parliament the abolition of the upper house, the adoption of the initiative and referendum, a national bank, old-age pensions and local government How little foothold the labour men really have in Australia is shown by the fact that in the face of this strong political organisation of labour in New South Wales the government does not recognise the trades-unions even of its own employés. I have told elsewhere the story of the treatment of the tram-car men of Sydney. The Minister for Public Works does not treat with his employés through their organisations. "But we ascertain their standard of wages and conditions and approximate them as closely as we can."

The two landmarks in labour legislation in Australasia are the minimum wage law of Victoria and the compulsory arbitration court of New Zealand. The minimum wage law of Victoria, so far as it goes, has a purpose similar to that of the compulsory arbitration law of New Zealand-to protect the livelihood of the people. But it does not go very far, nor, so far as it goes, does it go very well. This legislation was the response of Parliament to shocking revelations of the misery being spread through Melbourne and other towns in Victoria by the sweating system. Its purpose is to take away the power of the sweater to depress 
wages below the living point. It might be called a "living wage law limited." It is designated in the report of the chief inspector of factories as an attempt to deal with the sweating evil and intended to put an end to the "uncontrolled competition" by which "inconceivable misery" is brought to those who are "earning only a precarious daily wage." The initiative is not given to the people, as it is in the New Zealand arbitration law, but to the governor and council. In a similar way the machinery of the South Australian arbitration law was to be set in motion by the state, not by the parties to an industrial dispute, and the law remains inoperative. The Governor of Victoria, when convinced that the depression of wages and conditions of labour in any trade have become a matter of public concern, has the power to order the election of a "special board" to fix a figure below which wages shall not be pushed. These boards contain an equal number of representatives of employers and employés, as the New Zealand arbitration boards and court do, and each side, as in New Zealand, elects its own representative, and these representatives then choose a chairman. The boards are called "special boards" because each takes cognisance only of the special trade for which it was appointed.

Up to the present time five of these boards have been constituted, one each in the baking, men's and boys' clothing, boots and shoes, shirts, cuffs and collars, and furniture trades, and they are given by law authority to investigate the conditions of the trade for which they are appointed and to determine the lowest prices or rates which shall be paid to any person engaged therein. These rates or wages become legally enforceable on a date fixed by the board. These boards are in fact compulsory arbitration boards for the trades concerned. They differ radically, however, from the compulsory arbitration tribunals of New Zealand, for 
these have the power to fix all wages, as well as the minimum, and act upon the initiative of the people, and have much greater authority than the Victorian boards.

The New Zealand compulsion is not merely compulsion to obey the award. There are other compulsions equally valuable, and in fact indispensable. Not the least of these are compulsory publicity, with the powers of compelling the attendance of witnesses with the production of books, and the compulsion which compels disputants to refer their cases to arbitration. Under the Victorian law, up to the time of the last report of the chief inspector of factories, June I, 1899, for the year 1898 , the five special boards had made awards affecting 10,635 employés, and had increased their wages by an amount estimated at $\$ 500,000$ if they worked full time. In the baking trade the minimum was fixed at one shilling, twenty-five cents, an hour for men and five shillings a week for apprentices. This was an increase on the average of $\$ 3.75$ a week for the men. There was no increase in the price of bread to the consumer. In the clothing trade the minimum was made $7 s .6 d ., \$ 1.87$, a day of eight hours for the men and eighty-three cents for the women. The average wages of 4484 employés were increased sixty-eight cents a week, with no increase in the price of clothing - a result which the chief inspector considers "little short of astounding."

But the fact that the minimum rates for piece-work outside the factories were fixed too high led the manufacturers to insist that outside workers should become factory workers. Many women who had been working at home had to go into the factories. They have found, the inspector says, that the factories, with their light, sanitation, warmth and regulated hours were better places than their own homes. Those who could not go into the factories have had to do without work. The old and slow workers had to suffer like 
these women. The minimum proved to be more than the manufacturers were willing to pay these incompetents, with the result that many of them were converted into tramps. Under the New Zealand compulsory arbitration law the arbitration court has the power to fix the rates at which the "incompetent" men can be employed, and the Victorian boards have been compelled to follow this precedent and allow such persons to work for less than the official minimum. The export trade in clothing fell off during the year of minimum wages. The decent manufacturers gained by the elimination the law achieved of the unscrupulous sweating competitor, hut apparently are not able to. hold the foreign markets in competition with manufacturers abroad who have no minimum wage to pay.

In the boot and shoe trade the special board at first reduced the wages of the men to six shillings a day from $7 s$. $6 d$., but afterward, in consequence of the bitter complaints of the workers, increased this to seven shillings a day, \$1.75, despite the strenuous opposition of the employers. This determination of the minimum wage has increased the average pay of every man, woman and child in the trade by $\$ 1.08$ a week. But here again the "poor" workmen presented a stumbling block. The rate for piecework was made so high that the manufacturers would employ only young and strong men, and the "old and slow" men had to go on the street. For the shirt, collar and cuff makers the minimum was fixed at $4 d$. an hour, I $6 s$. per week of forty-eight hours.

A snag was struck in the furniture trade. There are a number of Chinese manufacturers of furniture in Victoria, and the department has found it impossible either to enforce the minimum or to ascertain what wages these Chinese capitalists really pay their Chinese labour. The reports they make to the government claim that their 
wages average $\$ 10.56$ per week, against $\$ 9$ paid by the white manufacturers. These Chinese meet the inspector with "the smile childlike and bland" immortalised by Bret Harte, and insist that they are obeying the law. "What can be done," the inspector asks, "with men who meet you with a bland smile and maintain without hesitation or doubt that the law is complied with when you are morally equally certain that the law is broken every day and hour in the factory? They are seldom rude. An unfailing politeness and courtesy marks all their utterances, but with the view of obtaining information an officer might just as well question the furniture they make." An inspector who spoke Chinese was obtained, but he was as helpless to penetrate the Oriental suavity of these undoubted law-breakers as the English inspectors.

Here is a specimen "determination" made by one of these special boards.

(Extract from "Government Gazette," April 2d, 1897.)

\section{FACTORIES AND SHOPS ACTS}

Determination of Special Board Appointed to Determine the Lowest Price or Rate of Payment for Bread-Making or Baking.

In accordance with the provisions of the Factories and Shops Acts the Special Board appointed to determine the lowest price or rate of payment for breadmaking or baking has made the following determination, namely:-

1. That the lowest price or rate of payment payable to any person for breadmaking or baking shall be twelvepence per hour.

2. That the number of apprentices under the age of eighteen years who may be employed in a factory or work-room in the bread-making or baking trade shall be one apprentice to every three men or fraction of three men.

3. That no improvers under the age of eighteen years shall be employed in a factory or work-room in the bread-making or baking trade.

4. That the lowest price or rate of pay payable to such apprentices shall be not less than five shillings per week.

5. That the price or rate determined by the Board shall come into force on the $3^{\mathrm{d}}$ of April, 1897 .

Dated at Melbourne, the $15^{\text {th }}$ day of March, 1897.

Hartley Williams, Chairman. 
The exports of furniture have declined under this minimum wage about one third, but this can be explained, the officials think, by other causes than the law.

"We can do nothing with the Chinese, nor with some of the white men," the head of the department said to me; and I learned not only from the officials but from the workingmen that evasion of the minimum by mutual arrangement between the men and the masters was not an uncommon thing. When the chief inspector asked an old man to sign a declaration that he was receiving the minimum wages as declared by the special board in his trade, the inspector says, "He looked me fair in the face and said, 'I will sign anything you like.' What he meant was, 'I must work, and to get and keep the work I will commit perjury if you like.' Can anything be sadder? After that day I determined that, so far as I could help it, I would never again put a man in such a position. There is some excuse for an old man, but when the same is done by young and strong men one begins to ask, how can Parliament protect the men against themselves?"

Representatives of the workingmen whom I met in the fine trades-union hall of Melbourne confirmed this statement of the chief inspector. "The men," one of these tradesunion leaders said, "lie to the inspectors about their wages." The reasons why the men do this are sufficiently indicated by the story just quoted. The chief inspector, almost in the accents of discouragement, asking what can be done to remedy the straits in which Victorian industry finds itself under this law, exclaims, "The only answer appears to me to be to provide work at remunerative wages for men able to work and old-age pensions for the old-age workers. It is no doubt very easy to say provide remunerative work, but how to do so has puzzled the wise men of the past, and is probably the greatest of the difficulties which confront the statesmen of the present day." In other words, the only 
remedy lies along the line which New Zealand has already travelled so far and with such success in its settlement of the unemployed in work and on the land and with its oldage pensions and other reforms.

There have been a few "labour members" in the New Zealand Parliament for many years, but there has not been a well-organised labour party as in Australia. The workingmen of New Zealand have seldom attempted to concentrate their vote on men of their own class, but have voted for the representatives who seemed to them to promise best for the people at large. This policy has given them great influence. A Liberal who wants to run for Parliament must send his name in to the tradesunion conference of his district. If they do not approve him it is of no use for him to stand. In the tidal wave of 1890 , when the Liberal party was swept into the ruling position it has ever since maintained, and of which it is assured until 1903 by the election of last year, there were twenty members who owed their election to the labour vote, but there were only six mechanics among them. The labour members in New Zealand, unlike those of New South Wales, Queensland and other colonies, have uniformly allied themselves with the Liberals.

Any one who thinks, from an outside view, that the New Zealand government is a labour government would be disillusioned instantly by getting an inside view of the attitude toward the labour elements held by some of the principal members of the New Zealand Liberal Party. A distinguished Liberal leader told me he had found the labour programme more popular and better understood among the farmers than among the workingmen. He insists that the country people are the real mainstay of the Liberal policy. His colleagues predicted to him that he would go down before his country constituency with the Liberal labour pro- 
gramme he had espoused; but he found, on the contrary, that it added to his strength. His explanation of this paradox is that "the country voters are better statesmen than the city workingmen." A very eminent New Zealand politician rang the changes on the workingmen's weakness, ignorance and jealousy. "With my early associations among the men I know how, in a crowd of workingmen, the moment a comrade begins to get up, to have some new ideas, to take the lead, his fellows begin to suspect, to ridicule and to pull down." One of the mast undoubted friends of the labouring man, speaking with the reverse of enthusiasm of the labour leader, said, "The first year the labour leader is a pretty good sort of fellow; he has high aspirations, is unselfish and patriotic. The second year he appears in a bell-topper hat and a gold chain. The third year he is invited to dinner by the members of the upper house, and on the fourth year he is neither fish, flesh, fowl nor good red herring."

Members of the Ministry make no secret of their disappointment over the fact that, with all their labour legislation, they are not strongest in the districts where the workingmen are strongest, and that labour leaders put into the upper house to give strength to the labour programme oppose the government instead of supporting it. These officials and leaders who criticise the workingmen know the class well, for some of them were workingmen. One of the Cabinet said, "All the members of the present Ministry have begun at the bottom. I know myself what it is to stay out all night in the bush up to my neck in mud and slush. This is a ministry of workingmen who have resolved that the government should do something to better the condition of the common people from whom they sprang, and they have worked faithfully to that end."

To understand the relations of the labourers and the Liberals the capital fact to be remembered is that New Zealand 
alone, of all the Australasian colonies, is not city ruled. It is not, like New South Wales or Victoria, a citified country, but it remains-and its conformation guarantees that it will always remain-country. There are no large cities and can be none. An observer from abroad notices at once that the leading men of New Zealand are not the sophisticated kind he finds elsewhere in public places. There is a certain rusticity-like that of the English country gentleman-characteristic of the best New Zealander even in the cities, and in this unmetropolitanised quality is to be found one of the great secrets of the sincerity and success of New Zealand reform.

The labour legislation of New Zealand began before the labour party came in, as far back as 1872 , though in a very mild form, and the Conservatives in 1890 , just before they lost control of the government, had introduced some new labour measures. The movement was at no time theoretical, but, like all the New Zealand reforms, was a response to the pressure of real evils. But though New Zealand did not act prophetically, nor in advance of the appearance of the evil-why should it be counted a fault in a nation any more than in a person to be forewarned?-it acted almost as soon as the evil gave its first intimation. Even Earl Onslow, conservative of conservatives, almost harsh critic of the New Zealand novelties, points out how the absence of vested interests permitted the country to carry out needed changes.

Prescience, however, had some part in the passage of the labour laws, and it had more there than in the land laws. In land the situation of the people of New Zealand had become desperate. But its industrial development was so slight that the wrongs to be remedied were felt by only a few, though all could see them. In the first debate on the factory bills their passage was urged even more on the 
plea of avoiding the ills which had undeniably overtaken England than to remedy visible ills in New Zealand. That some evils existed and that they had created some heat may be inferred from the remark made by one of the influential supporters of the administration in debate, that if the needed measures were not passed the iron hand of force would be used to deprive property owners of their property.

The really acute phase of the labour problem, and the one which stirred the nation, was in the unemployed diffculty. That, even before I890, strangely enough for so young a country, was real, terrible, a public menace. It was due primarily to the monopoly of land, but it made itself felt in every industrial centre of the country. A royal commission-they have royal commissions even in the colonies-had reported in 1890 that there was no sweating in New Zealand. In the debate on the labour measures very few serious evils of a strictly industrial sort were disclosed. The condition of the men and women and children in the shops was denounced as "perfect slavery." The shelter and food given the nomadic shearers, who go about from sheep ranch to sheep ranch during the season, were shown to be almost inhuman. There were complaints that the workmen were paid in goods at truck stores instead of in cash. The deductions of insurance money from the wages of workmen were a grievance. But no student of New Zealand affairs can doubt that these complaints all together would never have sufficed to generate political energy enough to move the people a step had not the unemployed spectre ridden them with spurs deep and sharp. New Zealand was moving at her ease toward the adoption of the English factory legislation before the popular uprising of I89o, but after that event the country moved with revolutionary rapidity, and, though it was monopoly of land and money and government that stimulated the uprising, the 
remedial measures dealing with the labour question were quite as sweeping as any of the others. When one recalls that the labour measures included compulsory arbitration, compulsory half-holidays for shops and factories, a compulsory educational requirement for factory children, the extensive abolition of the contractor in public works, an instalment of the minimum wage, the institution of a thorough and successful scheme for putting the unemployed on public works and at the same time making them settlers on the land, it will be admitted that the labour question received an extraordinary amount of attention from those who could not be called an industrial people in the usual sense.

In the years just before 1890 swarms of stalwart men, many of them skilled workmen, flooded the streets of the towns. Soup kitchens, relief works at degrading wages, two-and-sixpence a day, charity, all the agencies of demoralisation were doing their bitter work. One of the first things done by the new party of liberalism in $189 \mathrm{I}$, elected by the help largely of the votes of the workingmen, was to establish a Labour Department. This was an acknowledgment that the interests of the workingmen were as much a political matter as those of the farmers or miners. This democracy believed that the application of all the available energy of the community to the supply of all the needs of the community was a concern of the whole people if anything was. They saw that the government of the people was the only agency that had the power or the machinery or the motive to serve the whole people in the common interest, and the only one that had the means to use in any comprehensive way the information that could be gained by a labour department.

The new democratic fervour which was born in New Zealand of the oppression of the people by the land and money 
and other monopolies gave these principles immediate effect. Though the population was largely agricultural the new Department of Labour was made equal in rank to that of the Department of Agriculture, and the first minister was one of the most brilliant members of the party, the Honourable William Pember Reeves. The permanent head of the department is Mr. Edward Tregear, of whom the Honourable R. W. Best, Minister of Lands for Victoria, says, in his recent report of a tour in New Zealand, "Mr. Tregear has made a life-long study of labour problems and to some extent, no doubt, was chosen because of his wellknown sympathy with schemes for the amelioration of the condition of workingmen." One of Mr. Tregear's strongest characteristics is this sympathy with workingmen, but stronger than this is the common sense which dictates to him that under no circumstances is the workingman in distress to be "killed with kindness" by being pauperised. His motto is, "With work, everything; without work, nothing." That unflinching courage, which is possible only to the man whose culture is so broad that he instinctively despises everything but the truth, is characteristic of Mr. Tregear. His utterances in his reports concerning the evils of the present industrial system in general and the special evils of New Zealand in particular are of a frankness usually conspicuous by its absence in official labour literature. Thus he says in his report for I894: "Hold what theory we may, hide the facts in what casuistry we may, it remains that the wage-payer is the master of the wage-earner, the land holder is the master of the landless, and the owner of machinery is the master of the machinist."

It appears to be a popular idea with the officials of labour departments in some parts of the world that the purpose of such establishments is simply to provide a sort of university extension fellowship for academic students of sociological 
yucstions for the production of "scientific" reports to be embodied in formidable public documents distributed through the libraries of the world and never read. But the New Zealand Labour Department is for labour men, not for labour literature. This Labour Department is one which makes labour its care. Its first duty is to get work for workless citizens, and it puts far behind these in importance the publication of statistics and more, or less, learned conclusions from them. If a family wants a cook or a farmer a harvest hand the nation in New Zealand does not think it too small a matter to stand at hundreds of places in towns and at cross-roads with pen and paper to catch the names of those who might meet the need, and for this it makes no charge. If a country girl wants housework or a place in a factory, or a workingman getting no call where he is standing in the market-place would try his luck in another town, they find that the nation has anticipated them and is waiting for them in the Registry offices with a list of every one in the country who has made known that he is looking for such help as theirs. This democracy, in selecting the men who are to have the chance to work, gives the preference to the married and the elderly men. It can take into account the greatest public interest-not the interest of the employer, who looks only to get the most stalwart men for his money, but the interest of the whole community, in which the family is the greatest value-producer. Short-sighted profit-seeking secures a momentary advantage in the strength of the young and single men, by pauperising married men and lestroying the future source of supply of young single men. It gets nuts for one year by cutting down the tree which might go on bearing nuts for generations.

From first to last the department, under Mr. Tregear, has regarded as its first and chief duty- "its vital duty," he calls it-the practical task of finding where labour was 
wanted and depositing there the labour running elsewhere to waste. In the last year 2 II 5 men obtained work or received temporary advances of passages, etc., to enable them to reach employment. Of these 937 were single and III7 were married men, the latter having 4759 persons dependent upon them. The woman's branch of the department at Wellington has also found employment for 426 women and girls during the year. From June I, I89I, to March, I899, the Labour Department has found work for 21,607 men, upon whom 52,246 persons were dependent. This is an average yearly of nearly one per cent. of the population.

Of the effect of this upon the workers Mr. Tregear says, in his report for 1898 , "The help of the government has been of immense advantage. It has often meant rescue, if not from starvation, from the reception of charitable aid, the acceptance of which is generally unspeakably bitter to honest working people. It has sometimes prevented a feeling of utter despair taking possession of a defeated labourer and has enabled him not only to get a few weeks or a few months work at a critical time, but in many cases has allowed him the means to leave an over-crowded town and proceed to a district where one job would succeed another until he has found a place in rural society that he can fill with advantage both to himself and to his neighbour."

The means employed by Mr. Tregear are the maintenance of a widely extended system of agencies for bringing workers and work together, a strict decentralisation of the unemployed by scattering them through the colony, and a refusal to give anything. Aid is furnished only by sending the worker to private employment or, if to public works, only to such as were necessary and reproductive. This is in clear contrast with methods used in neighbouring colonies, as in New South Wales. There, as shown by official investiga- 
tions both by New South Wales itself and by government agents from New Zealand, the unemployed were invited to the cities by gratuitous food and shelter. They were put to work at things obviously useless and at make-believe wages, and thereby degraded. The unemployed in many cases were shipped into districts where disputes were pending between employers and employés, with the result that this state agency, established and supported by the taxpayers to improve the condition of the working people, was used to depress the level of wages and living of all the people. In New Zealand, to carry on its work of shifting labour from the congested districts to those where labour was in demand, the Labour Department created two hundred agencies, covering the whole country. In the towns various officials, like factory inspectors, undertook the duty, and in the country districts the constables acted. In only a few large towns were special agents appointed.

If the transfer of workers to work had been left wholly to the efforts of the Labour Department no great results could have been expected; but, as has already been shown. New Zealand, through other departments, has entered upon a wide and intelligent and successful system of making work for the unemployed. When the Labour Department has gathered its unemployed it finds both the Land Department waiting with its roads and the Public Works Department waiting with its court houses, post-offices, railroads, bridges, etc., ready to take the men off its hands if private employment cannot be found for them.

Two features have characterised this policy from the beginning: the men were given nothing but a chance, and no work was macle for the sake of making work. Nothing was undertaken that was not necessary and that would not be profitable to the community. There was no setting of men to shovel sand from one point only to shovel it back 
again, as was done in the parks of Sydney, and from the beginning there was never the least touch of charity. The man had to pay ultimately for everything-for the railroad ticket taking him and his family to their new home, for the food and shelter they had on the way, for the tools he found ready for him, for the tents, for everything.

Another feature of Mr. Tregear's administration of the Labour Department has been that he has conceived it to be his function not to provide work for manual workers alone, but, in his own phrase, for "all classes of labour, mental as well as physical."

It is true, notwithstanding all that has been done by the Labour Bureau, the Land Department, the Department of Public Works and the railroads in finding work for the workless, that there are still unemployed in New Zealand, and still the distress that comes from forced idleness. Even in good times like these we find such items in the New Zealand papers as this, in June last: "Since the beginning of the cold weather nearly two hundred persons have been supplied with coal and blankets in Christchurch, and a large number of others are on the books"; and in May, "We learn that fifty unemployed waited on the mayor to ascertain whether the city council intended to put any works in hand to absorb the surplus labour." Evidently the New Zealand methods do not fully meet the great modern problem of how to save the golden stream of human energy that is running away between our fingers every day, as the seconds tick off the unused days of millions of men made idle-a problem not of poverty but of wealth, of wealth which has set labour free by new machinery, new methods, new combinations, and has not yet found the new "place where" for labour's disengaged lever, a problem of wealth producing poverty that waits to be made wealth again. All that New Zealand can claim and does claim is that it has done more 
than others, and that its efforts are in the right direction. But manifestly they are only a beginning.

There is no eight-hours day for men in New Zealand by law, but the hours of women and children are restricted, and this operates as a hardship in many cases. The Chinese in their laundries are subject to no limitation as to hours, being men, while the white laundry women who work in competition with them are compelled to stop at certain hours. This makes heavier the burden of the women, already too poorly paid and too hard worked. It is being urged that this discrimination between men and women be ended. When women had no political rights and powers it was natural enough that they should be given especial protection by law, but now that they have the ballot they stand on equal terms with men before the law-makers, and their special immunities should cease. In the factories again, as well as in the laundries, the requirement that the women stop work at a given moment, while the men can continue, puts the women at a disadvantage. It is characteristic of the New Zealander that the plan most favoured for equalising the men and women is not to take away from the women the protection of a legal prohibition of too long hours, but to give it to men, who, for the sake of health and the public good, require a fair share of leisure quite as much as the women.

There is a venerable - and fruitless-agitation in England for a weekly half-holiday. Men like Lubbock and the Duke of Argyle have prevented the application of the only method by which such a measure can be made effective. The fetish of self-help has blocked every attempt to make this movement successful. It could be made successful only by being made universal-all shops, all factories must observe it, or none would. This universality can be had only by political action, and this means a law, and law means compul- 
sion. This boon for the clerks of the retail stores was one of the first labour measures proposed and carried in New Zealand, and it was made effective there by compulsion. "Compulsion," an eminent New Zealander said in defending this policy, "means only that the duty is binding on all, and that the interests of all require it. If, under such circumstances, it is wrong to compel, our whole civilisation is wrong, for its fundamental method is that when the interests of all have been clearly defined the minority must submit. There is always an intractable or criminal minority in every company. To withhold compulsion in matters affecting the interests of all is to submit the interests of all to the rule of a few. The ideal is that all shall unite and do the right; the actual is that there are always degenerates, criminals, cranks, or belated ones who cannot yet do the right. We have to choose between compulsion of the many by the few or the reverse. Compulsion is a choice of evils, but it is here the right choice."

Just as the people of New Zealand made binding upon all the duty of arbitration and thus secured industrial peace, they have made binding upon all engaged in retail trade the half-holiday. They do not require merely that the employés must be given the holiday, the employers must take it, too. The shop must be closed. The law has neglected to safeguard this concession to the shop clerks by stipulating that they shall not be worked longer hours on the other days to make up for the time they get by the holiday, and the result is that in many cases, though the people have the halfholiday, they work as long as before and sometimes longer. It is proposed to remedy this by limiting the hours during which shops can be kept open, and this, like the half-holiday, will be got compulsorily. "It seems idle," Secretary Tregear says, "to ask the public to refrain from purchasing. after a certain hour. In such matters the public has neither 
head nor heart. It is when that right is established by statute that it obtains recognition from people too much absorbed in their own business to recognise that they are causing injury to others."

Merchants and banks must close their offices at five o'clock in the afternoon during two thirds of each month. The extension of this protective legislation to the "upper class" of the labour world is a New Zealand novelty, and there is a strong demand that the benefits of the compulsory arbitration act be also given the same classes. When the half-holiday was first established the opposition was very angry. The measure was denounced by the merchants as an outrageous "interference with the liberty of the subject," but now the employers like the holiday as much as the clerks, and any proposal to return to the old order would be resisted by the one as much as by the other.

Shops in New Zealand are under inspection like factories. Women and children are not allowed to work more than fifty-two hours a week in shops, and not more than fortyeight in factories. There must be seats for the girls, and their right to use them is zealously protected. The Marquis of Salisbury, Premier of England, took pains to rise in his seat in the House of Lords and speak to prevent such a boon being given to the girls in the English shops. The Premier of New Zealand helped this reform through his Parliament. There is a half-holiday for factories as well as shops. Factories must be closed after I P.M. on Saturday without deduction of pay for time-workers. Mothers are not allowed to work for a month after the birth of a child. Overtime is prohibited, except on permission of the inspectors, and with that it is allowed for only twenty-eight days in the year. No child under sixteen is allowed to work unless found physically fit by an inspector, and no child under fourtecil is allowed in a factory at all. There are no half- 
timers. The regulation of the amount of air, space and sanitary conditions is under the absolute power of the inspectors, who can insist upon their being made such as they consider necessary for the life and health of the working people. All the factories are under these regulations, and the word "factory" is so closely defined that no one can escape. A factory in New Zealand is any place where two or more people are occupied in industry. A man and one helper are a factory, although the helper be a member of his own family. Even hawkers are regulated by being defined by law as "a shop."

These laws are not nullities. In Auckland one employer was fined sixty-six shillings, $\$ 16.50$, on five charges of employing an assistant after one o'clock on Saturday. Another employer was fined $\$ 8.50$ for failing to provide proper seats for his girls, and another, for causing an assistant under eighteen years of age to work more than nine and one half hours in one day, had to pay $\$ 9$. A baker who had worked his girls all night was fined one pound, $\$ 5$, for each case, and warned that he had made himself liable to a fine of $\$ 50$ on each charge. The judge seemed to show a dyspeptic desire to increase the fine when the poor man pleaded that he had been engaged in baking hot-cross buns for Good Friday, and his further plea that some of the girls were members of his own family did not save him. A restaurant keeper, having kept two of his girls at work for more than eleven and one half hours, was fined $\$ 36.50$, although one of the girls had had three afternoons off the same week. Another baker, for neglecting to allow one of his girls a full hour for dinner, was fined two pounds therefor, and had to pay $\$ 7.50$ costs in addition.

This strictness of the enforcement of the factory laws is proof enough of the honesty of the officials, but there is the same kind of human nature in New Zealand as seeks 
elsewhere for its own selfish ends to make breaches in such safeguards of the welfare of others. A man prominent in the Labour Department told me that at the beginning of lis career as inspector he had the greatest difficulty in making the manufacturers believe that they could not blind the administration of the law by putting guinea scales on the eyes of the inspectors. He was constantly "approached" in this way. If he visited a factory one day a bale of its shawls or whatever its stuffs were would come to his house the next morning.

The principle of the minimum wage is accepted in New Zealand as well as in Victoria. In New Zealand minimum wages are being constantly determined by the decisions of the arbitration court, but there is also a minimum wage established by law. The factory act stipulates that the pay for overtime must not be less than sixpence an hour extra. Another minimum wage enactment was made by the last session of the New Zealand Parliament. One of the industrial evils there has been the employment of a large number of young men and women without pay under the pretence that they were sufficiently remunerated by being taught a trade. To put an end to this abuse the "Employment of Boys and Girls without Payment Prevention Act" was passed. This enacts that in all cases of the employment of young people under eighteen years of age there must be paid not less than four shillings, one dollar, a week for girls and five shillings for boys, irrespective of overtime. This legislation was not, so far as I could learn, especially promoted by the working people, as, indeed, very little of the labour legislation has been. I must confess I was much interested to be told by one of the men most active in securing its passage that it was hoped that one effect of it would be that the girls, who would certainly be thrown out of factory life by the requirement that they be paid, would betake 
themselves to domestic service, to the relief of the New Zealand housekeeper, who has the same domestic help problem that her sister the world over has, and to the moral and physical elevation of the girls themselves.

New Zealand supplements its system of free and universal primary education by refusing to allow uneducated children to be employed in its factories. Any child under fifteen years of age must be able to show a certificate of the fourth grade before it can be taken into employment in a factory.

Workingmen in New Zealand have been bitterly complaining for years of the exactions to which they were subjected under the pretence of accident insurance. Constant deductions were made from their wages by employers for such insurance. The employer might pay the money to the insurance company or he might put it into his own pocket. The workingman would suffer this deduction one week, and the very next week, losing his place, would find himself uninsured, and if he took another place be subjected to another deduction. It was claimed that the consent of the workingmen was obtained, but, as Secretary Tregear said in answer, "Under the pressure of modern competition in industrial life 'consent' is a word of pregnant significance." In the last session of Parliament this extortion was stopped by adding accident insurance to the business of the Life Insurance Department and by the "Wages Protection Act," forbidding all employers from making any deductions whatever from the wages of their employés for accident insurance and forbidding the insurance companies to receive from any workingman money for insurance of which the employer was to get the benefit.

When the factory acts and other labour measures were first introduced they were received by the Conservatives with the greatest indignation and alarm. Eminent members of that party predicted in Parliament that they would 
prove "a delusion, a shame and a snare," and that they would create revolutionary dissatisfaction among the people whose liberty they so much curtailed. Of all the blue ruin thus predicted in 1891 the only realisation has been the ruin which finally, in the election of 1899, overtook the authors of these prophecies, the Conservative Party, which then, a shattered and hopeless wreck, disappeared forever beneath the waters of New Zealand politics.

Nothing can be more striking than the contrast theoretical and practical between the Victorian minimum wage system and the New Zealand compulsory arbitration law. The latter is a thorough-going scheme, built up solidly on a statesman-like basis, to deal not only with a few cases but with the whole problem of the civil war between capital and labour. Though the cure of the sweating system was not one of its avowed purposes, the New Zealand compulsory arbitration law alleviates it with a far greater thoroughness than the "special boards" of Victoria. New Zealand, the only country which has a compulsory arbitration law, is the only country in which for five years, with one or two insignificant exceptions, there has been no strike or lockout in the world of organised labour. The New Zealand experiment answers every test which can be applied to prove the claim of a new institution to be a permanent and veritable addition to the world's social inventions. Practically it does what it undertook to do-it ushers in industrial peace. Philosophically it is an extension to a new fieldthat of industrial anarchy-of an old institution-that of the law-by which social peace has been created in the other territories of disorder. Every day since its introduction the law has struck its roots deeper into the life of the New Zealand people, and it further approves itself by producing not only what was expected of it but many new and almost equally important fruits, such as checking cut-throat com- 


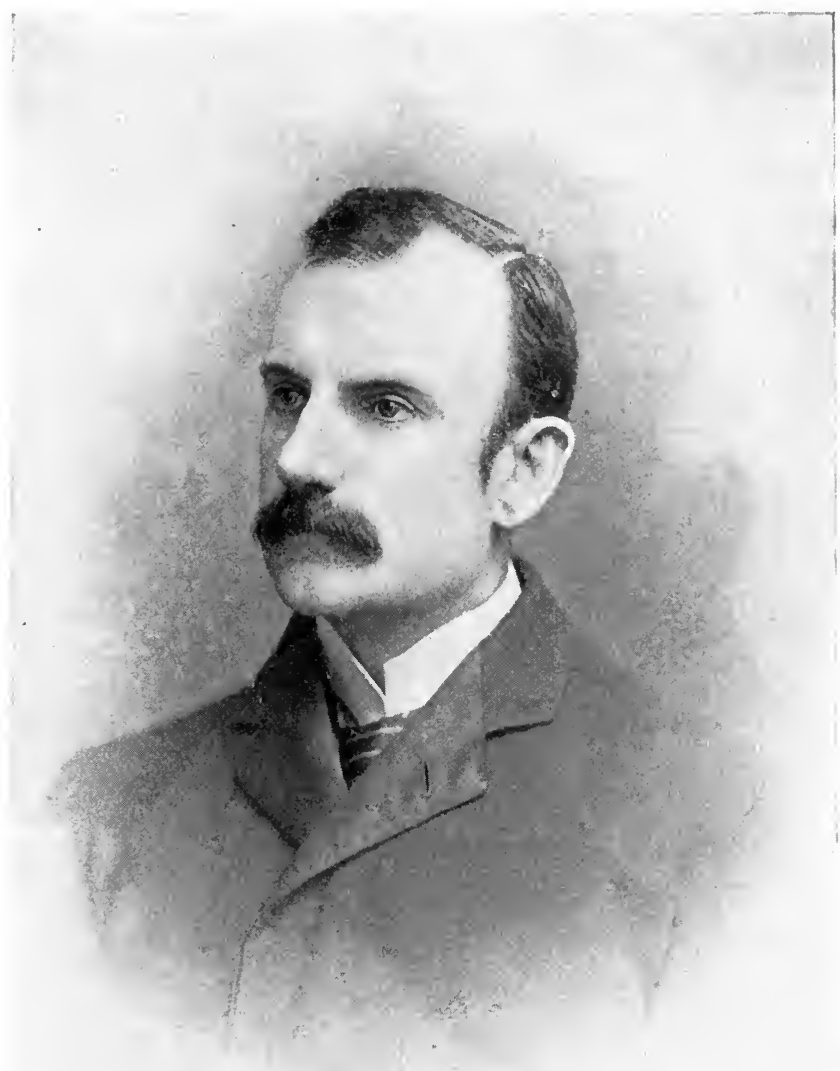

The Hon. William Pember Reeves, Author of the Compulsory Arbitration Law. 

petition between business men and putting an end to trade dishonesty. Another feature of the New Zealand law which commends itself to the philosophical student of institutions is that its appearance came in the direct line of evolutionary development. Other communities, notably Massachusetts, had carried arbitration up to the Rubicon of compulsion. New Zealand took the next step.

The law is entirely without precedent-nowhere in the world except in New Zealand is there any compulsory arbitration-and it has been so successful that it may fairly be questioned whether it has not established a precedent that no other modern people largely committed to industrial life can afford to disregard. The compulsory arbitration law did not spring out of theory, and has not ended in theory. It was the remedy sought as a way of escape from practical embarrassments of the most serious sort. The strike of 1890 brought New Zealand as well as Australia within a day's journey of anarchy. This was followed by apprehensions of a big railroad strike. To save New Zealand from being ravaged by these industrial conflicts, more terrible in their sum-total of losses than a foreign war, the then Minister of Labour, the Honourable William Pember Reeves, who lately came to America as the official representative of his government at the Commercial Congress in Philadelphia, began to study what had been accomplished by other nations in arbitration.

Mr. Reeves was a young man; his career had been that of a lawyer, journalist, poet, politician. His compulsory arbitration law is the first piece of legislative work which came from him to attract attention outside New Zealand, but I am distinctly of the opinion that that will, in the judgment of coming years, entitle him to a place in the first rank of political inventors.

Mr. Reeves studied all that had been done by other coun- 
tries, and was forced to the conclusion that "voluntary arbitration is a sham." He traced the development of arbitration in all the leading countries up to the Massachusetts Board of Conciliation and Arbitration. This he found the best of all and lacking only one thing to make it completely successful-compulsion. New Zealand began where Massachusetts left off, and has succeeded where Massachusetts failed. Mr. Reeves saw that to be effective arbitration, like taxation, must be compulsory, not that the minority might rule the majority, but that it might not. Time and time again in New Zealand the majority of masters and men in a trade had agreed to terms of settlement or methods of arbitration, sometimes after years of negotiation, only to have the whole structure of their civilised effort overthrown by an irreconcilable minority of commercial cutthroats determined not to abate one jot or tittle of their privilege of murderous competition.

The theory of the compulsory arbitration law is that the majority must rule. There are three parties vitally interested in every industrial dispute: labour, capital and the state. Whichever side the state finds right is therefore in a majority.

The New Zealanders are not at all sensitive about the use of compulsion. They are the most democratic people in the world, and they believe in whatever compulsion is necessary to prevent the minority from ruling. They see that compulsion is only another name for law. Taxation is compulsory, sanitation is compulsory, education is compulsory, and good order is compulsory. The compulsion which any citizen can avoid by behaving himself and doing the right is not a compulsion which need worry respectable people.

The New Zealanders do not think the compulsion of the Court of Arbitration as odious as the compulsion of riotous labourers on one side or of Gatling guns and Idaho bull 
pens on the other. The existence of the power of compulsion makes compulsion often unnecessary. Some of the pleasantest incidents of the operation of the new system have been those in which employers and employés in trouble with each other have appeared before the judge of the arbitration court for his intervention privately and by means of it have reached a harmonious settlement without even the slight loss of time and money in a proceeding before his court.

As to violations of the law there have been some, but the court has found no difficulty in imposing penalties on the guilty men, and they have found no difficulty in submitting to them.

How shrewd and correct was Mr. Reeves' conclusion that compulsion was the missing link in arbitration is shown by the fact, seen over and over again in the proceedings in New Zealand, that the disputants themselves prefer compulsion to conciliation. A majority of the cases, instead of resting in the decisions of the conciliation boards, go on up to the arbitration courts, though these in almost all cases sustain the boards. Both sides want compulsion, because they know that is final.

Considering that there was no law to guide Mr. Reeves and no experience to serve as precedent, the fact that he was able in so untrodden a field to contrive a measure which should go into successful operation must be considered a legislative feat of the highest order. His bill for compulsory arbitration was debated through three sessions of Parliament, twice thrown out by the upper house, and finally, so cogent had been Mr. Reeves' treatment of the matter, was passed almost without opposition. It was enacted in 1894 , to go into effect in 1895 . The first case arose in 1896 .

The principal points of the law are, first, procedure for voluntary arbitration, with no publicity and no investigation if the parties can thus settle their difficulties among 
themselves; but if they cannot, the law shows its other face. If their differences are irreconcilable by themselves the parties must arbitrate if either of them so elects; fight they shall not, if either wants arbitration. The compulsion of the law is threefold: compulsory publicity, compulsory reference to a disinterested party, and compulsory obedience to the law's awards. The state has no powers to intervene in any dispute, even for inquiry, of its own motion. Those concerned sue and are sued as in other courts.

The law was originally entitled "An Act to Encourage the Formation of Industrial Unions and Associations and to Facilitate the Settlement of Industrial Disputes by Conciliation and Arbitration," and the plan of arbitration as conceived by Mr. Reeves, and so successfully operated in New Zealand, contemplates the organisation-voluntarily, of course - of both employers and employés, separately, into associations and unions as the foundation of the whole structure. It is believed to be better for each side and for the public that the parties to an industrial dispute should be committees rather than mobs. To induce capital and labour thus to organise, special privileges are granted them, the greatest of these being the right to call the other to arbitration. Only workingmen who organise and register under the arbitration law are subject to it. Compulsory arbitration is therefore after all voluntary arbitration, so far as the workingmen at least are concerned, for the act cannot be invoked by or against any workingmen who are not organised into a trades-union. Employers may be sued singly, otherwise the act could be defeated by the refusal of employers to form themselves into associations. There is a Board of Conciliation in each of six districts into which New Zealand has been divided, and before these boards industrial disputes are first tried. If a settlement is not achieved before the Conciliation Board the case goes on 
up to the Court of Arbitration, which sits for the whole colony.

On both the Board of Conciliation and the Court of Arbitration employers and employés are represented equally by men of their own choice. The presiding officer of the Court of Arbitration is a judge of the Supreme Court of the colony. This procedure guarantees that throughout the entire investigation both sides shall be represented by men of their own class, familiar with all the circumstances of their calling. Experts can be called in to represent both sides and to act as members of the boards or the court. Lawyers are not allowed to appear for either disputant except by the consent of both sides. The chairmen of the boards must be "impartial persons" who are "willing to act." By making a judge of the Supreme Court President of the Court of Arbitration the colony gives a guarantee to the disputants that the casting vote and the conduct of the investigation shall be in the hands of the best that the colony can give of experience, ability, dignity and disinterestedness. Every precaution is taken that the proceedings shall be cheap, expeditious and untechnical. The tribunals are expressly charged to make their decisions in accordance with the common sense and equity of the case, and not to frame their awards in a technical manner. Meanwhile the industry goes on. Neither employer nor employé is allowed to stop work to escape the conciliation or arbitration proceedings, nor to do so in order to evade an award. The law even reaches back of the time at which its intervention is invoked. At any time within six weeks after workingmen have struck or employers have locked out, the aggrieved party on one side or the other can go to the Arbitration Court, begin proceedings, and obtain an award. In this way even if a strike or lock-out has begun the court is able to stop it. The employer cannot get out of a dis- 
pute with his men by discharging them and putting on new men. The men laid off can go before the Arbitration Court at any time within six weeks and get redress.

In South Australia employers can be brought in only if they have registered, but in New Zealand the employer cannot, as in South Australia, keep himself out of the reach of arbitration by thus omitting to register. The workmen can call him before the court on their own motion.

The law has now been in active use since May, 1896. In that time there have been about fifty cases before it. It was believed by the author of the law that the Court of Arbitration would seldom be resorted to, and that the boards of conciliation would settle most of the disputes, but it has worked out quite otherwise. Two thirds of the cases have gone from the boards of conciliation up to the Court of Arbitration, but most of the decisions of the conciliation boards have been sustained by the court.

The Arbitration Court has shown moderation and good sense in using its delicate powers, and the judges have done as little "legislating" as possible, either as regards the logic or the arithmetic of business. But in their decisions there can clearly be seen emerging some new principles of economic relation. The court, for instance, insists, wherever possible, that trades-unionists be given employment before non-unionists are put to work. This for the reason of public policy that all interests are promoted by the organisation of labour, and because the trades-unions by their efforts and sacrifices improve conditions and rates of wages, and are fairly entitled to the first consideration. The court has also lirected that when work grows slack it shall not be given to a few, but shall be divided among all the men, thus keeping all employed. It has also ordered that a preference should be given to residents, and that they should be given work before outsiders are employed. 
The ordinary employers of New Zealand, like employers everywhere, are bitterly opposed to trades-unions. These help the workers to get better prices for the labour which the employers prosper by buying cheap, and this preference shown to trades-unionists has been a sore point with them ever since the principle was adopted by the Court of Arbitration. In Igoo the Employers' Association of Canterbury obtained an injunction from the Supreme Court forbidding the Arbitration Court to give trades-unionists preference of employment. This was at once met by the Canterbury Trades Council by a counter application to the court for an order to set aside the injunction. This application was successful, and the Arbitration Court is now fully and finally established in its right to give this preference whenever it seems called for by the circumstances of the case.

Another reason for giving preference to trades-unionists is that it was a proper compensation to them for the deprivation by the arbitration law of their power to strike. Under the old system they could enforce their demands by striking, and since the public, on account of the great damage to public interests, forbade these trades-unions to use this weapon they are given in lieu of it the first chance of employment.

"Preference" must work both ways. The Arbitration Court, in giving organised labour preference of employment, calls on them in return to give a preference in the supply of labour to employers who are organised under the law. Another requirement made of the trades-unions, in consideration of the preference of employment, is that they must not be monopolies, but must admit all competent men to the union.

The court has also taken pains to prescribe, even in cases where it gave preference of employment to the members of unions, that non-unionists who were at work should not be discharged. It has also, where members of unions have 
been discharged obviously to intimidate or destroy the union, ordered that they should be reinstated and has awarded heavy damages to their union.

The court in its awards fixes an average or "minimum wage" as the rate necessary to be paid the ordinary worker, but it provides very carefully for the men who are not able to earn as much as this. They can still be employed at lower wages than the average, but, for the protection of the union rate, it is stipulated that if any dispute arises the rate of wages given such men must be submitted to the local Conciliation Board for approval.

Both the boards of conciliation and the Court of Arbitration have summary powers of visiting any premises and questioning any persons concerned in an industrial dispute. They can compel the attendance of witnesses, the production of any books and papers needed, and can imprison any one refusing to obey their summons. Every precaution is taken by the act to prevent injurious publicity of the secrets of business. The hearings are public, so that public opinion may be properly informed, but the court can at any time. at its own discretion or at the request of any of the parties, go into secret session.

In other countries than New Zealand we say public opinion is the supreme court in determining the issues between labour and capital, but, except in New Zealand, we give public opinion neither any means of informing itself as to the facts nor of effectuating its opinion if it forms one. New Zealand gives the court power to ascertain all the facts by compulsion, if need be, and then places in its hands power to enforce the conclusions of this public opinion. In America the public are helpless to learn the facts of a dispute; in New Zealand they are sure of learning them all and correctly.

There is a new "Song of the Shirt" in New Zealand under 
the compulsory arbitration law. The employers of the sewing women in Auckland gave notice shortly after the new law came into effect of a reduction in wages. Under the old régime of the woman who sits in unwomanly rags, with fingers weary and worn, these sewing women would have had no recourse but to retreat from their crust and tea and garret to a weaker cup of tea and a scantier crust and a dingier garret. But under the compulsory arbitration law the old "Song of the Shirt" is a "lost chord" in New Zealand. In this case the women's organisation called the manufacturers into court. They had to show their books and to make good every statement as to their profits and the wages their women were earning. While this debate was proceeding in the rooms of the Arbitration Court the sewing women sat secure in their factories, lighted and ventilated and safeguarded by the sanitary and other care of the state, and their work went on. The sewing woman did not have to strike, she could not be locked out, her work could not be taken from her, her wages could not be cut down except by the approval of the court. This is the new Song of the Shirt.

One of the by-products of the arbitration law is the prevention of frauds on the public. When in the course of investigation of any labour troubles revelations are made of frauds practised in the trade, the judges in their awards can make rulings which will put an end to them. In a dispute in the tailor trade it was shown that it was the practice of some firms to deliver to customers factory-made goods on orders for custom-made clothing. In its decision the court stopped this by requiring that all custom-made work should be done in the shop of the employer. The workingmen know and resent the deceits they are compelled to perpetrate. These are often, as in this case, an injury to them as well as to the consumer, for they are 
forced to do inferior work at inferior prices, or to see work that they should do go to others, as in this case. The open court room of compulsory arbitration gives them the chance to let out the trade secret and protect both the public and themselves.

The workingman or employer who does not want to obey the award of the court need not do so. There is no compulsion to work or to keep the factory open, but the employer who closes his factory can reopen it, the workingman who leaves his work can begin work again, only in exact compliance with the terms of the award. The award may have been made for two years. Labourers and capitalists under the régime of private war amuse themselves by trying to starve each other out, careless meanwhile that they are starving also the public interests concerned in the industry. But these tactics are futile in New Zealand; the state cannot be starved out.

Any workman may stop work and any employer may shut down during an arbitration or after an award for any good reason other than to escape or defeat the jurisdiction of the court, but it will be of no use for him to stop work or slut down with any hope of evading it. The workingman can come back to work, the employer can reopen his factory during the life of an award-and this may be for two years-only by obeying all the points of the decision of the court.

The principal opposition to the law came from employers, but they are now seeing that it can be of as much service to them as to the workingmen.

One of the most interesting uses I found made of the law was to protect a majority of the employers in a trade from the guerilla competition of a minority. I learned of cases where manufacturers were actively promoting the organisation of their employés into trades-unions, for an 
appeal to the Court of Arbitration. They were doing this in order that unscrupulous competitors might be restrained from cutting wages in order to enable themselves to cut prices.

One of the largest employers of the colony described to me the situation of things under the act as one of "perfect comfort." "Under the old system," he said, "our differences with our men had to be settled by a brutal fight. Now two committees meet before the court, and meanwhile the industry goes on just as if nothing were the matter."

Another large employer declared that for the first time in the history of the colony manufacturers now are able to make future contracts with confidence, since the awards fixed all the conditions of labour perhaps for years ahead.

In the report recently submitted to the Victorian government by the Honourable R. W. Best, its Minister of Lands, after a tour of investigation made by him in New Zealand to study its land and labour laws, he quotes the following to show how some of the principal employers regard the act:

"Speaking at a special meeting of the Dunedin Chamber of Commerce, on October 19, I897, to consider certain bills then before Parliament, Mr. James Mills, Managing Director of the Union Steamship Company, and one of the largest employers of labour in New Zealand, is reported by the Otago 'Daily Times' to have said that 'personally he thought the Conciliation and Arbitration Act was a very beneficial one and one of the most important that had been passed, and he felt that they were under a debt of gratitude to the present government and to Mr. Reeves for maturing the bill in its present shape. Probably the measure was capable of improvement, and it would be improved from time to time, but he was sure that compulsory arbitration was the true solution of all labour difficulties." "

In an address by the Right Honourable Richard J. Seddon, 
the Premier of New Zealand, at a representative gathering of London capitalists interested in the mining industry, one of the strongest points which the Premier made to encourage the investment of English capital in New Zealand mines was the stability given to business enterprise by the arbitration law.

"With us," he said, "a strike of the miners is impossible, as it is also impossible for the owner of the mine to shut down. That is a condition of things which does not prevail anywhere else. There is a safeguard for you. The result has been this, that even the employers, who were the first to object to that legislation, are to-day the strongest in favour of it, because where they have strikes of any kind where there is a large amount of capital invested the effect of that capital being laid up for weeks, and exactions being demanded which that capital could not bear, would be as distastrous as it would be to our mining. The law, as it stands now, has prevented disputes which, if there had been an industrial struggle, must have meant a loss of about a million of money to us as a small community, whereas the whole cost of the proceedings would not amount to $\mathfrak{f}_{\mathrm{I}}$ ooo."

The employers, most of them, like compulsory arbitration. It enables them to make their business arrangements for months or years ahead with certainty, and without the necessity of putting "strike clauses" in their contracts. It relieves business of one of its most harassing annoyancesthe perpetual friction with labour. A little easy manœuvring with the men brings cut-thoat competitors before the court and puts them uncler the compulsion of law to pay the same wages and give the same treatment to their men as decent employers do.

The workingmen like compulsory arbitration. It ensures them at all times and under all circumstances a full and 
fair hearing for their demands. When they are resisting a reduction or demanding an increase of wages it enables them to learn the facts of the situation and all of them. It fixes the product of their labour not by a false "law of the market" as interpreted by the greed or the whip hand of a master, but by the true "law of the market" never before ascertainable. For the first time in civilisation the organisation of labour is not merely tolerated, but given a premium. The law fixes a living wage or a minimum wage, and yet allows the superior man all the advantage his strength and skill deserve. Again for the first time in history the toiler has found a place where he meets his employer on equal terms, with no temptation to cringe or to bully. This law puts in the hands of the workman an irresistible means of stamping out the moment it appears in any industrial centre the first tendency to sweat the working people.

An employer in any part of the country detected in an attempt to cut wages or worsen conditions can be called before the court and straightened out, and what might have developed into a widespread spoliation, running from one competitor to another, justified by this merchant because it had been adopted by that competitor, is arrested at the very start.

The satisfaction of the workingmen is universal, and this feeling is shared by the labourers of other colonies. At the Trades-Unions Conference in Sydney, New South Wales, in 1899, it was resolved that the New Zealand method of compulsory arbitration was the most satisfactory one for the settlement of labour disputes, but no such law has yet been enacted by the New South Wales Parliament.

It must not be supposed that strikes are impossible under the new law. Unorganised workingmen may still strike. There can be no arbitration if all the masters and all the 
men in a dispute agree not to appeal to the law. Organised labour may strike if not registered under the law. If registered it may withdraw by giving three months' notice. There have been one or two unimportant strikes, but the broad fact is that organised labour does register, does not withdraw, and that neither it nor the unorganised men strike.

When, last year, an important amendment to the law was proposed it went through the New Zealand Parliament without a word of opposition, although it was one of the stormiest and angriest sessions which had been held for many years. If any real damage had been done to the interests of the colony by the law, or if there was any popular feeling that it was tyrannical, then was certainly the opportunity to show it. The principal opposition paper of the colony, the Otago "Daily Times," declares that it is impossible to assert that the effect of the law has been injurious.

But in the administration of this institution it is being proved again, as everywhere, that eternal vigilance is the price of the survival of any good thing. Lawyers are creeping more and more into the cases, with no gain in expedition or justice, and the late judge of the court, Judge Edwards, now succeeded by Mr. John C. Martin, formerly Public Trustee, made several decisions which greatly limited the field within which strikes and lock-outs can be prevented by law. He refused to allow grocers' clerks the right to appear in the Arbitration Court, ruling that theirs was not an "industrial" pursuit and consequently not entitled to the benefits of arbitration. And the same judge excluded street-car men and livery-stable employés because not engaged in "industrial" pursuits. These decisions have called forth a great deal of criticism and protest in New Zealand. The position of the court appears to be that no 
occupations are industrial except manufacturing. It is pointed out that this is a use of the word which is not supported by any philological or economic authority, nor by any other judicial authority. The principle of this decision would shut out seamen from the arbitration of the court, and yet it was to save New Zealand from a repetition of the maritime strike of 1890 that the law was primarily passed. Public opinion in New Zealand seems to favour the more sensible view that where strikes and lock-outs are there is the field of the law of arbitration, and that industrial matters are any that involve the relation of capital and labour, of employer and employé. "The reason of the law is the law," Blackstone says.

The evil which the law sought to remedy was not economic civil war in a few places, but in all places. A strong movement is now being made in the Parliament of Igoo to add to the law a clause which shall put it beyond the power of any such interpretation to defeat its obvious purpose. If this succeeds we may expect to see the mercantile as well as the manufacturing world brought within the sphere of industrial peace. Premier Seddon, in receiving a delegation bearing a protest from the grocers' clerks against their exclusion from the Arbitration Court, declared himself in favour of an amendment of the law which would bring all workers within its provisions, and this will undoubtedly be achieved in the legislation of this year, in which the hand of Mr. Seddon and his party will be supreme.

As to the effects of the law on public welfare the facts are eloquent. It was predicted that the experiment of arbitration would introduce an era of industrial disturbance which would be fatal to the prosperity of the country. The following figures of the number of hands employed in the factories of New Zealand tell how this prophecy of evil has been falsified. 


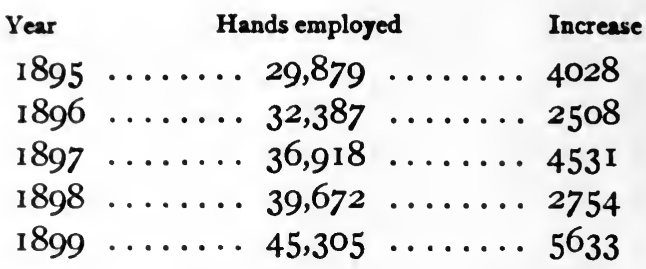

In Victoria we have seen that the exports fell off in some of the industries affected by the minimum wage law, which is a kind of arbitration law, but no such result has followed in New Zealand. In his introduction to my recent book, "A Country Without Strikes," the Honourable William Pember Reeves says :

"The only serious argument-beyond the theoretical objection to state interference in any form-which has been brought against the law by English writers has been a statement that it has hampered enterprise and checked the growth of manufactures in the colony. New Zealanders know this to be quite baseless, for they know that the manufactures of their colony have fully participated in the prosperity of the last quinquennium. For some years past labour in almost every trade has been fully employed, the numbers of the workless have fallen progressively, new factories have been opened, new buildings erected, and the shopkeepers who deal with the working classes admit that business is better and bad debts fewer than at any time in the last twenty years in the colony. The annual reports of the chambers of commerce and the periodical reviews of trade and business published by the New Zealand newspapers on both sides in politics tell the same tale."

The Compulsory Arbitration Court of New Zealand has an aspect of even greater importance than the industrial peace which is assuredly a very great aspect. In this arbitration court New Zealand has achieved what the people of 
the world have been sighing for for centuries-cheap, uniform and speedy justice. It points the way to the realisation of the dreams of quick and true justice for all, which is the greatest need and the dearest hope of the people of the world. And the Compulsory Arbitration Court of New Zealand is a light on a hill to those who are seeking a means of establishing international arbitration. The nations will get arbitration only as the people of New Zealand got itby compulsion. When the nations make up their minds that the duty of arbitration shall be mated with the right of arbitration, and that as no nation ought to fight no nation shall fight, and that as every nation ought to arbitrate all nations shall have the right to demand arbitration, and when they, as the people of New Zealand did, create a tribunal with the power to enforce these rights and duties and to punish any people that violate the new international law, then, and not till then, shall we have the possibility of international arbitration. Law and order must have its policemen between nations as well as within the nations.

The only country in the world where there have been no strikes or lock-outs for five years is the only country in the world that has a compulsory arbitration law. That country is New Zealand, and New Zealand is to-day not only more prosperous than it ever has been before, but, so far as my observation goes, is the most prosperous country in the world. Not even a New Zealand advocate of compulsory arbitration would claim that its prosperity was due to compulsory arbitration, but the prosperity certainly has falsified all the predictions that disaster would follow. 


\section{CHAPTER XI}

\section{QUARANTINING THE PANIC OF I893}

THE panic of 1893 struck Australia on time and struck it hard. In six weeks half the great financial concerns of the Australian continent went to the wall. This meant much more there than it would mean for us, for the Australasians are the most highly financed people in the world. What the statistician calls "the banking power of the people" is greater there than anywhere else. We of the United States then had sixteen times the population of Australia, but only five and one half times its banking capital. The banking power of Great Britain, the financial centre of the nations, is \$120 for each man, woman and child, but for young and distant Australia it is $\$ 185$ each.

At the beginning of April, 1893, the four millions of Australians had a banking system in full career, with assets in round numbers of $\$ 900,000,000$. In May, $\$ 450,000,000$ of this lay in ruins.

Though New Zealand was in its track the cyclone never arrived there. The democracy of New Zealand does not believe in the alleged immutability of the laws of nature, including the laws of trade. This high area of money disturbance on its way from Australia in I 893 was successfully countered by a more powerful anti-cyclonic pressure generated by the wit of democracy. At that time, 1893, the Bank of New Zealand was a private institution, largely owned in London, but it was the chief bank of the colony, and kept 
the cash of all the principal business concerns and the funds of nearly every public body, including the general Treasury. There were I486 of these public accounts, among them charitable aid, town and road boards and 633 school committees. The government had nearly $\$ 10,000,000$ on deposit, and in this was the money of its Postal Savings Bank. There were also a number of private savings bank balances. The bank had $\$ 55,000,000$ of the $\$ 76,000,000$ of the banking assets of the colony. One sixth of the population was directly involved in its fate. It had $\$ 22,000,000$ of deposits belonging to 35,000 depositors. These figures are not small even to us.

New Zealand's remoteness and its insular independence made the earthquake wave of panic move slowly toward it. No signs of trouble were visible to the public when, in I893, the banks held a meeting and asked for a legal tender law like that which had been passed by Parliament in New South Wales earlier in the same year.

This legal tender law was not what we should understand by that term. It authorised the banks to issue a dollar of circulation for every dollar of property they had in excess of what they owed. But it also obliged the Treasury to give gold for these notes whenever presented. By this law, in other words, it offered to guarantee all the notes and to cash in gold the surplus assets of the banks to the last dollar if necessary. This made their surplus liquid, as bankers say-not merely as good as gold, but as good as gold coin, which is something even better.

This offer of relief made the relief unnecessary. The banks found no need to use the new privilege given them. and their issues of notes actually declined. For another entire year, until June, I894, the smooth current of New Zealand business went on without a ripple, while all the rest of the world was passing through failure and liquidation. 
During the year 1894 there was a decline of only $\$ 68,000$ in the banking deposits of the colony, and a contraction of about $\$ 1,250,000$ in the loans; prices were falling, but the shrinkage in revenue and exports and imports was slight, and the country was prosperous.

But on Friday, June 29, I894, Parliament and the Ministry were thunderstruck to learn from the officials of the Bank of New Zealand that that institution would not be able to open its doors on Monday morning unless it had help. There was but one day to decide what to do and to put into law. It was not a question of saving the bank, but saving the country. Its welfare for a generation was at stake. Parliament, putting all party differences aside, by an overwhelming majority passed, without change, a measure presented by the Ministry. It acted without any other information about the bank and the crisis than the assurance of the Ministry that the bank was sound and would weather the storm if assisted.

That in this leap into the dark Parliament was following blind leaders did not appear until afterward; fortunately so, for if the Ministry and Parliament had known what they found out later, their power of action would have been crippled, as happens to those who know too much.

By this legislation Parliament granted an advance from the colony to the bank of $\$ 10,000,000$, repayable in ten years -in 1904. The money was got by the sale in London of $\$ 10,000,000$ of bank stock paying four per cent. a year guaranteed by New Zealand. In addition the stockholders were called upon to pay up $\$ 2,500,000$ on their reserve liability. The government inserted the head of the camel of public ownership into the tent of this private bank, by putting a representative of its own at its head as president, with the right of veto on any transaction, and subjected the management to the scrutiny of a public auditor. 
As happened under the Legal Tender Act of 1893 , tranquillity followed. There was another year of peace in New Zealand, and in New Zealand alone, for everywhere else the boa-constrictor of panic contraction was crushing trade and industry in the pitiless way the business man struggling with bankruptcy, and the workingman tramping the roads for work, know so well.

But in I895 again out of a clear sky and with no warning the Ministry came to Parliament with the announcement that the bank for which they had done so much, on the assurance that if done all would be safe, had been found by the president and the auditor put in by Parliament to be practically a wreck. All the capital was gone. Of the bank's nominal assets of about $\$ 55,000,000$, over $\$$ I $3,000,000$ were but the refuse of sheep ranges and other real estate, which had been taken on foreclosure from its reckless borrowers by this reckless lender. The good properties had long since been sifted out and sold. Every effort had been made by the representatives of the state to retrench and rebuild, but this burden of dead real estate had been found to be too heavy to be borne.

"There is still a magnificent portion of the business which is sound," Parliament was told by its representative in the bank; "but unless this load of effete matter is lifted the bank can no longer be carried on."

Unless immediate help is given, "such a calamity will result," he continued, "as has never yet been experienced by any British colony."

This was sickening. The Ministry, on the strength of the assurances given them, had assured Parliament the year before that the bank was solvent, and that the loan of $\$ 10,000$,ooo would launch it anew upon a career of prosperity without the loss of a cent to the people. Now the truth came out that the bank was gone, and the $\$ 10,000,000$ were 
gone also unless the Treasury put in still more millions. The same Ministry was still in power, and friends and enemies united in the outbursts of indignation with which this news was received. But a joint committee of both houses of Parliament and of both parties found, upon investigation, that the bad news was true and that whoever was to blame the bank could not survive without further relief. It unanimously recommended that this be given.

After less than a week's debate Parliament went in $\$$ I 5,000,000 deeper. It did this by taking preferred stock in the bank to the amount of $\$ 2,500,000$-making itself the largest stockholder-and by guaranteeing the bank to the extent of $\$ 13,000,000$ against all losses on the sale of its derelict real estate. This was the full nominal value, and was admittedly at least $\$ 4,250,000$ more than the real value. Then Parliament divorced the bank from the land business in which it should never have been embarked. The real estate was taken out of its hands, and a company especially formed to market it. The state by its guarantee practically enabled the bank to cash all the land that it had to take for bad debts-\$13,000,000-and assumed itself the weary task of selling it off, which was certain to consume many years and involve heavy losses.

The stockholders were again called upon and summoned to pay in $\$ 5,000,000$ more on their reserve liability, if they could raise it, as many of them could not. The bank was empowered to buy a competing bank to increase its chances of making money. The business of the colony in London was taken from the Bank of England and given to the Bank of New Zealand to add to its earnings, and a government director was put on the board of management.

As a method of relief this was far more effective than such a proceerling as that of the State of New York, which, in our panic of 1837 , passed a law suspending all rights of the 
people to proceed against the banks for the enforcement of their obligations.

In all, in these three years, I893, I894 and I895, the government and the people-only 750,000 of them-went in to the tune of $\$ 37,500,000$ made up as follows: $\$ 10,000,000$ in 1893 for the guarantee of the note issue which they did not have to make good, as the circulation was not needed by the business of the colony and was never put out; $\$ 10,-$ 000,000 in I894 for the guarantee of the bank stock; \$13,500,000 in 1895 guaranteed the bank on the sale of its real estate; and $\$ 2,500,000$ for the new stock subscribed for by Parliament.

Adding to all this the $\$ 7,500$, 000 which the stockholders were called upon to pay in, we have a total of $\$ 45,500$,000 as the sum for which the people and the stockholders became liable to rehabilitate this concern. Leaving out the $\$ 10,000,000$ liability on the guarantee of the notes, which was never called for, the total advances by the state to this private bank reached the sum of $\$ 26,000,000$.

Against this the colony has for its reimbursement what it can get out of the sale of the real estate-there is certain to be a loss of at least $\$ 5,000,000$ on this item-and whatever the bank can repay from its profits, all of which are ear-marked for its indebtedness to the state, excepting a limited sum conceded to those stockholders who have responded to all the calls made on them.

These advances were practically an addition, and a very considerable one, to the public debt of the country, which already in 1893 was in round numbers $\$ 200,000,000$, but they do not appear in the debt statements. For the express purpose, among other things, of avoiding all appearance of debt expansion, the new obligations were created in the form of guaranteed bank stock, guaranteed real estate debentures and Treasury purchase of bank stock. 
When Parliament in 1894 was scared into a panic lest there should be a panic, and, under the whip of the ministerial majority, put through in a one night session, between two days, an advance of public money of $\$ 10,000,000$ to this private bank, it supposed, and there is no doubt the Ministry also supposed, that the bank was an honest bank and solvent, but caught through no fault of its own, in one of the whirlpools of the financial deluge that had just swept Europe and America and Australia, and that it needed only a temporary lift to right itself.

But the representatives of Parliament who went into the bank to protect its advances found that the Ministry and Parliament had been deceived, and that the institution was in the condition in which the sister of Lazarus thought his body must be after it had been three days in the tomb.

Worse still, the truth gradually forced itself into recognition that the affair with the Ministry and Parliament, June 29, I 894 , was a coolly planned scheme of the directors and leading stockholders to throw upon the country the liabilities of a bank after they had swallowed its assets. It was a "raid" arranged in London. The command of it was entrusted by the London capitalists concerned to a man whom they sent on from that city, because they knew he had the confidence of the colonists, as he had once lived among them, and had been in the management of this very Bank of New Zealand. Hastening from London to Wellington this gentleman opened fire.

"There was a revolver pointed at our heads," the Premier afterward told Parliament.

"If the bank and the country are to be saved from ruin, the bank must have $\$ 10,000,000$," this gentleman said at a conference with the Ministry and the leaders of Parliament at three o'clock in the morning, and it must have it "to-day," and "to-dlay" he got it. 
The letter in which he formulated this demand and the act of Parliament responding to his "hold-up," bear the same date, June 29, I894. In this letter he gave the assurance that "this does not imply that any heavy losses in the bank's business have been made. To the best of my knowledge and belief no such losses have been made."

Upon his arrival from London three weeks before, he had been given a statement prepared by the officers of the bank, showing a loss of $\$ 5,877,000$ on the real estate transactions alone; but he "forgot" this, saying only in an off-hand way that there was "a big hole to fill." The statement of the bank which he submitted showed a profit on the last year's business. When asked what security there would be for the $\$ 10,000,000$ demanded, he pointed to the "paid-up capital" of $\$ 4,500,000$ and the stockholders' reserve liability of $\$ 7,500,000$, and declared it was not to be questioned that that was an "ample margin." But this capital was then all gone; every cent of it lost.

He assured Parliament in the strongest language that by the advance of ten millions, "the state will not lose one penny."

He was a shrewd fellow and knew his people. He sugared his pill with talk about this opportunity for New Zealand to establish for itself "a national bank," like "the great nations of the old world."

The owners of the bank had squeezed out dividends as long as there was a cent squeezable, and then, and not till then, they saw the admirable advantages of a "state bank."

What he said, Parliament did, and did it "to-day," and London knew-it was afterward discovered-what Parliament did before it was done. A friend of this man said in Parliament the year after, "He is very astute, and capable and careless hearers might be led to erroneous conclusions by such a gentleman." 
As soon as the work he had. been sent to do was accomplished he left the country. When asked in Parliament where this "astute" gentleman was, the Premier could only reply, "Where, O where?" He went to South Africa, but evidently he did not organise the Jameson raid, for had he been its leader it would have been successful.

A legislative investigation clisclosed that the bank had been in an unsound condition since 1888 , and that the directors had been paying dividends which were not earned. A large part of the losses had been due to loans which the directors had made to themselves, not only on insufficient security, but under circumstances which led a committee of stockholders, in 1888 , to hint at the desirability of criminal proceedings. Between 1888 and 1893 , when the bank was unloaded on Parliament under cover. of the threat of a panic, its directors had paid out $\$ 1,328,000$ in dividends, sometimes seventeen and one half per cent. a year, and altogether nearly one hundred and fifty per cent. on the amount of its paid-up capital. And yet, during these very years, the bank was making losses at the rate of $\$ 8400$ every day, a total of $\$ 20,000,000$ in all, of which $\$ 15,453,000$ were plainly confessed by being "written off."

During a large part of this mad career of financial dissipation the gentleman who had "put the revolver to our heads" in 1894 had been active in its management. A ring of directors and speculators had used the money of the depositors and stockholders to financier, swindling "booms" in land. As bank directors they made loans to themselves as land speculators. "Undrained swamps and barren hilltops," anything that there was a chance to sell at a profit to the gullible public was good enough security for these men. The bank had been the greatest enemy of the bona fide settlement of the people on the land, and had been the friend of the land grabber and jobber. 
"For twenty-five years the management had been so recklessly extravagant that no words could be found too strong to characterise it," was said by one of the members of Parliament.

"This inflated concern has hung over the colony for years like a nightmare," said another.

"We have found it to be a den of gambling, dishonesty and rascality, and we have not yet reached the bottom of it," said still another.

The stockholders' committee in I 888 had threatened criminal proceedings against the directors who had paid dividends that had not been earned. Immediately upon this intimation that the directors should be punished, some one appeared in the lobby of Parliament and obtained the passage of a law, almost in silence and without a division, which not only allowed them to continue paying such unearned dividends, but "looked backward" and legitimised their illegal and probably criminal acts in paying them in preceding years. Commenting on this one of the members of Parliament said:

"At all times we have found that capital exercises an undue influence on the legislature."

Whatever the Bank of New Zealand wanted from the government it was always able to get.

A loud cry for punishment arose in Parliament when the rotten character of the institution was made clear. One of the special objects of a Parliamentary committee of 1896 was to uncover the guilty men and ascertain the exact facts on which they could be indicted and tried; but the man who had been made president of the bank by Parliament to protect its interests refused to testify on this point. Others who knew the facts followed his example. The investigation became a farce and the matter was allowed to slip out of "practical politics." 
In Australia, for some reason, the fate of swindling bank managers and directors was very different. Scores of them were sent to jail and stayed there for years. Perhaps the fact that the panic was averted in New Zealand and the public was not maddened into vengeance accounts for the failure of justice. The members of the Ministry pledged themselves to pursue the matter "as sure as the sun rises to-morrow," and to find out and punish those "who are now living in wealth and luxury at the expense of the poor unfortunate stockholders and taxpayers of New Zealand," but nothing has been done to redeem the promise.

Although these damning facts came out in all their depressing details in the year after Parliament made its first advance of ten millions, and while it was deliberating what to do further, if anything, "not a single member" of the joint committee representing both parties and both houses of Parliament, appointed to discover the truth and make a plan, "thought for a moment," as one of its members said in the debate, "of allowing the bank to stop," and Parliament took the same view by a large majority.

It was, perhaps, the severest test of its good sense and good temper the New Zealand democracy has ever had. The country had dropped $\$ 10,000,000$ into a bottomless pit, and was asked to drop in some $\$ 15,000,000$ more to save itself by saving a bank which was incontestably a sink of financial corruption and incompetence. What made action favourable to the bank especially bitter to the Liberal party then in power, was that the institution had always been one of the bulwarks of "conservatism," and had thrown all its influence against the progressive policy of the people. Political processions of the Liberal party marching along the streets would stop cheering when they came to the building of the Bank of New Zealand and give it rounds of dismal groans. 
"It was the greatest foe of liberalism in the country," a Liberal said in Parliament, but still he supported the bill to keep it afloat.

Parliament undoubtedly represented public opinion correctly in not allowing its indignation and resentment to blind it to the true issue. It was urged in and out of Parliament, when the first appeal was made in 1894 , that there was nothing in the circumstances of New Zealand that threatened it with panic. Prices were low, speculation absent, indebtedness not inflated. The bank, it was said, should be left to dig its way out of the pit it had digged itself into or to perish there.

But the great fact was, and the democracy saw it, that this private bank was the source of supply, the dealer in control, of the greatest necessity of modern life-credit, on which the production and distribution of all the other necessities depend. It owned the most important piece of machinery in the colony. It was the heart of the inflow and outflow of the country's industrial blood. This administration of credit was a great public trust. When the trustees abused their trust, the public had neglected either to control them or to assume the trust itself.

The million or two that might be lost now was a penalty for the belated recognition of the folly of leaving an article of such universal necessity as credit, to be exploited by a private enterprise at its own sweet will. It was a price the public had to pay, for awakening to the public interest, in an economic function not less important than the national defense against a foreign foe; but it was also a cheap price to pay for escape from such devastation as the people of New Zealand had just seen sweep over Australia and Europe and America.

This was the situation of New Zealand, and the common sense that saw this point and acted on it was the common 
sense of the average man. Some of the most successful business men in Parliament, and some of the members most experienced in public life, opposed every suggestion of relief. Thirty-three of the members were new men. Parliament was denied all information except that there was an emergency. The other bankers in the colony could not be summoned to advise, for they were representatives almost wholly of foreign houses and competing banks; and this was a crisis which must be settled on New Zealand lines for New Zealand.

There was no time to deliberate over a plan for "nationalising" the credit machinery. Do what we demand and do it "to-day." the men in possession of the machinery said, or we will blow the whole thing up, you and ourselves included.

Had the bank stopped as these men threatened, all the money of the government would have been locked up in London, and at home its savings bank depositors would have been unable to draw their money; the Public Trust office and Life Insurance Department and the Advances to Settlers office would have been crippled; the 35,000 depositors of the bank would have been left without funds to carry on their business or to pay their current bills; the thousands of borrowers would have been called upon to pay their loans$\$ 75,000,000-$ at a moment when they would have been unable to get money anywhere else, and could have sold their property only at ruinous sacrifices. Industry would have been suspended, workingmen and women thrown out of work, forced sales would have started the prices of merchandise and land on a downward grade. Imports would have declined, and with them the customs revenue. The receipts of the railroads would have followed the same course. There was a foreign trade in and out of $\$ 65,000$,ooo a year, and a private wealth in land, improvements, 
machinery, merchandise and other property of $\$ 750,000$,ooo, all dependent upon the maintenance unimpaired of the credit system of the country. The failure of the bank would have been a stroke of paralysis followed by death for many and slow recovery for the rest.

This was the situation with which a surprised Parliament found itself faced on the morning of June 29, and which had to be settled "to-day."

The democracy, though inexperienced and taken by surprise and deceived, has proved itself a better banker than the "private enterprise" which affects such scorn for the "state"-except when it wants some privilege from it.

The Premier said in 1893 , in Parliament, that he would not allow any bank in the colony to fail. The remark was received with cheers on all sides of the house. The people and their representatives had not the slightest notion how serious was the responsibility they assumed, when the hour struck the next year for them to redeem this jaunty promise. Yet, though so inexperienced, their performance has been so successful that it is well worth the study of democracy everywhere else. As Lowell says, the world has come to have but one set of nerves, and we all have the same headache at the same time.

First. The democracy prevented the panic which the private banker had prepared.

Second. The frauds were investigated to the bottom which private banking had perpetrated and concealed.

Third. For the first time the New Zealanders now have a bank which they know all about and they are the only people who have this. The kind of thing that has gone on behind the scenes in many another country in Europe and America, but has been sedulously kept behind the scenes, has been democratically spread out in this New Zealand experience for everyone to look at. 
Fourth. Under democracy all the revelations of financial unsoundness were published to the world without producing the slightest ripple of disaster. The merest whisper of such publicity would have sent a private bank to the wall.

Fifth. The stockholders who had allowed their directors to wreck the bank, were compelled to make good their reserve liability to the utmost farthing of their ability.

Sixth. In the Australian liquidation the depositors had to lose part of their money. They were "impounded" as the word is. In New Zealand the depositors lost nothing.

Seventh. The funds which should have been kept liquid for daily use the capitalists locked up in real estate speculations which dragged on for years. The democracy separated the land business from the banking business, and cleared up all the bad debts, real estate and other.

Eighth. The government put in all the new capital required.

Ninth. The stockholders for twenty years had been unable to install directors who would direct. But the state has got itself honestly and intelligently represented.

Tenth. The democracy shrewdly bought another bank to reduce competition and get the benefit of consolidation.

Eleventh. The government, because it is the government, is able to get capital cheaper than the bank when in private hands. It borrowed in London at four per cent. The bank would have had to pay at least six.

Twelfth. For the first time this great organ of the financial life of the colony is under the régime, which, in its motive, takes equal account of the welfare of the borrowers, stockholders and the general public. The private director might think of all these, might wish he could consult all these interests, but he would be Utopian and a bankrupt if he allowed his action to be influenced by them. But that 
democracy should be so influenced is a matter of course and helps, not hinders, its success.

Thirteenth. Notwithstanding all the dark predictions at the time, it now promises that none of the money advanced will be lost, and that the stockholders who have been able to keep their stock paid up will be saved. They would certainly have been ruined either by the continuance of the old management or by liquidation. At the last meeting of the stockholders to elect the two directors to whom they are now limited, it was shown that there was a prospect of dividends in a future not very remote.

These anticipations are confirmed by the last report of the business of the bank laid before Parliament in July, I899. The deposits and loans are up to their former level. The bank is paying interest on all its obligations, and is reducing the principal of its indebtedness out of its profits. It is earning the interest on all the money advanced and invested by the Treasury. In addition, it is also paying to the Treasury out of its profits, as provided for by the scheme of liquidation, $\$ 250,000$ a year toward the losses which are made in the sale of the bank's "cats and dogs" of real estate. The sale of this real estate is proceeding at a rate which promises a total loss of about $\$ 5,000,000$, but this will not fall on the state, but on the bank which must make it up out of its profits. It paid last year $\$ 250,000$ toward this deficit, and, as its profits increase, its contributions to the deficit will increase.

The New Zealanders claim for themselves and their bank now the best position in the Australasian colonies, and the figures bear out the claim. That is worth a great deal of money to the country and is bringing in a great deal every year.

The colony is prospering and the bank will share in all the gains of the community. So recuperative is democracy 
- the spirit of reciprocity perpetually fed with new strength from the ever renewed youth of the people. If the debt to the Treasury is not extinguished in 1904, when its advances fall due, it will be an easy thing to arrange an extension.

There was more than a touch of justice in this bank's coming home to roost with the government. The public works policy of 1870 , by which large amounts had been borrowed in England for wholesale construction of railroads and other public improvements, and for assisted immigration, had had much to do with inaugurating the era of speculation which had demoralised the bank. The beginning of its unsoundness was found, in 1894, to date back twenty years. The managers had been tempted into reckless banking by being given on deposit a large amount of this borrowed money. They naturally sought to find employment for these deposits. If bank managers do not get deposits they are dismissed; if they get deposits and do not loan them they are dismissed; if they loan them and lose them they are dismissed.

The state, too, had practically certified the bank to be safe to the people by putting its money-their money-on deposit with it. A determined colonial treasurer could have kept himself posted at all times as to its real condition or he could have withdrawn the public account.

The Ministry through its bank directors comes into the most intimate connection with the business movements of the colony, but never has there been the least whisper, in the press, or on the platform, or in Parliament, that any improper use has been made of this power.

The last time the bank came before Parliament, when, in 1896 , the government strengthened its representation on the board of directors, one of the most influential members of Parliament, and one of the best known citizens of New Zealand, the Honourable M. S. Grace-the brother of Ex- 
Mayor Grace of New York-took occasion, in words which were not challenged, to declare that, throughout the whole affair, there had been absolutely no corruption, political or ministerial. He said :

"It is probably the first time in history that such extraordinary and complex legislation, involving millions of money, has been affected without any greasing of palms. What would such an operation have cost in London, in Paris, Berlin or Rome? Any person who has had any opportunity of knowing London can conceive what such an operation would cost. Whatever our follies-and they are of a transcendental character-our people are not politically corrupt."

There can be no doubt that the plan of relief by the Treasury advance of $\$ 10,000,000$, which Parliament was so peremptorily called on to make "to-day," was unnecessarily expensive. The proof of this is found in the fact that the money, when advanced, was not needed. The year after the advance was made, in I895, the manager of the bank wrote to Parliament that this advance of $\$ 10,000,000$ "had filled the bank's coffers with money, for much of which either no employment whatever could be found, or only nominal rates could be obtained."

Such a plethora was doubly obnoxious under the circumstances. It was a heavy tax on the people and a renewed temptation to the bank.

A "State Bank" had been suggested in New Zealand before these occurrences, and every new development in the affair gave texts for and against. The sentiment in favour of such a bank is not as strong in the democracy of Australasia, perhaps, as it is in that of Switzerland, where year before last it received a large vote; but there is in both Australia and New Zealand a large constituency for such a proposal. 
One of the most prominent business men in the colony said in Parliament, in opposing the first advance of ten millions :

"Long before we are done with this bank it will silence the outcry for a state bank, at least for this generation."

But by another member, the attempt thus to use this trying experience to discourage any connection of the state with banking, was met by the cogent remark that the trouble was not in any way due to the connection of the state with the bank, but to the private rascality that had compelled the state to interfere.

"Private banking has been a shame and a scandal all over the world, and has brought the various colonies affected almost to ruin."

This member hoped never to see the day when the Bank of New Zealand would be again managed by private capitalists.

I found the opinion widespread, among the best informed, that the government was certain to be compelled to continue to keep its hand in the management of the bank, beyond the period first fixed for the termination of its guarantee-1904.

The bank, no matter how well it may do, cannot by that time repay the Treasury, which will have to go on to get its money back.

One plan which has been proposed to escape the evils of political management is that the state should put the bank under the charge of a "non-political board." A precedent in point is furnished by South Australia. This colony has organised its state mortgage bank in precisely this way to keep it out of politics. It is managed by a board of trustees, who are not responsible to the Ministry, who can be removed from office only by very difficult steps, and who, therefore, can act independently and carry on the bank for strictly commercial interests. But this device is not a pop- 
ular one in New Zealand. The New Zealander is a political animal, and does not believe in confessing bankruptcy by making assignments of his political powers to "nonpolitical boards."

"Parliamentary government is played out," the leader of the Opposition exclaimed in debate on one of the bills for the relief of the bank-one reorganising the management. The house had been then sitting for twenty-three hours continuously on this measure. It was, as he said, utterly exhausted. He complained that Parliament had not been allowed even a few hours to read the evidence and the report of the investigating committee on which the bill was based, and was called upon, without time for study or proper debate, to pass the proposed law at one sitting. He begged for an adjournment for a few hours that the house might be able to qualify itself to decide the grave and important question involved in the bill of the management of the bank in which the Treasury now had a liability of $\$ 26,000,000$.

This request the Ministry, for reasons it thought sufficient, refused to grant, and the bill was passed by the house after a sitting of twenty-four hours at two o'clock in the morning, but failed in the other house.

The first legislation for $\$ 10,000,000$ was put through in one night. An attempt was made to push the second pledge of $\$ 17,000$,000 in the same way, but the protests of the members finally secured a week's time.

There is an appalling intimation here of the possibilities of Parliamentary government, especially in view of the increasing tendency to add commercial and economic functions to political duties; that is, to go into business, or to control business. The power that Parliament forges is the mightiest known to man. No citizen so humble or so far away as to escape; no one so strong that he can resist. A few words put after the magic formula "Be It Enacted," and the prop- 
erty, welfare and morals of millions suffer change for good or bad over continents, and a mortgage is fastened on the happiness and the energies of unborn generations.

Evidently as democracy grows more powerful and "the people" comes nearer, our present Parliamentary methods must give way to something less impulsive, something less like weather and more like growth.

One of the greatest disasters the world has ever seen awaits the people who attempt to administer enterprise on socialistic principles through present Parliamentary methods. It would break down as no other civilisation has broken down before. All that a co-operative society is, Parliamentary government is not in the administration of business.

Banks, railroads, mines, insurance, manufacturing, "state theatres," "municipal restaurants" cannot be run by mass meetings, stump speakers, caucuses and ministerial pull-no more than private banks and business can be so run. What we know as "politics" and socialism are incompatible. Democracy itself will see that democratic industry must not be at the daily mercy of majorities of one and of "all-night" sessions, nor of officials appointed to please politicians.

Perhaps the school will take the place of the nominating convention. With public schools and colleges as the gates to all public industries, aptitude instead of office-seeking will determine the choice of vocation, examinations instead of influence will give the appointment, and performance instead of pull will give promotion. We shall have selection instead of election; processes working with the steadiness of nature's laws instead of waves of popular feeling which defeat in the long run the popular will.

A happy combination of circumstances like that in New Zealand where the country was young, the people honest, and the "general good" still a slogan, may make such an 
episode as we have described in this chapter a success, but it would be folly not to see that the success was a "fluke," and that to count upon it would be to make it impossible again. A special providence watches over children, fools and democracies until they count on it.

But, though a fluke, the success of the New Zealand antipanic remedy in this incident is incontestable. There was no run on the Bank of New Zealand, no bank in the country had to close its doors, in New Zealand alone there was no panic. The financial wind there did not blow where it listed. The New Zealand Canute said to the commercial sea of troubles floating in everywhere else, "Thus far and no farther," and it stayed. In every other centre of financial civilisation thousands of people's hearts broke as they stood in line before the doors of breaking banks.

A comparison of the statistics of the three principal colonies of Australasia tells the story:

\section{BEFORE AND AFTER THE PANIC}

BANKING DEPOSITS

\begin{tabular}{|c|c|c|c|c|}
\hline $\begin{array}{l}\text { New South Wales, } \\
\text { Victoria, } \\
\text { New Zealand, }\end{array}$ & $\begin{array}{c}1891 \\
£ 42,988,550 \\
50,183,551 \\
17,497,436\end{array}$ & $\begin{array}{c}1897 \\
£ 40,114,033 \\
37,742,473 \\
19,958,781\end{array}$ & $£^{2,461,345}$ & $\begin{array}{c}\text { Loss } \\
£_{2,874,517} \\
12,441,078\end{array}$ \\
\hline \multicolumn{5}{|c|}{ IMPORTS } \\
\hline $\begin{array}{l}\text { ew South Wales, } \\
\text { ictoria, } \\
\text { ew Zealand, }\end{array}$ & $\begin{array}{r}£ 25,383,397 \\
21,711,608 \\
6,503,849\end{array}$ & $\begin{array}{r}£ 21,744,350 \\
15,456,482 \\
8,055,223\end{array}$ & $£^{1,551,374}$ & $\begin{array}{r}£ 3,639,047 \\
6,255,126\end{array}$ \\
\hline \multicolumn{5}{|c|}{ EXPORTS } \\
\hline $\begin{array}{l}\text { New South Wales, } \\
\text { Jictoria, } \\
\text { New Zealand, }\end{array}$ & $\begin{array}{r}£_{25,944,020} \\
16,006,743 \\
9,566,397\end{array}$ & $\begin{array}{r}£ 23,751,072 \\
16,739,670 \\
10,016,993\end{array}$ & $\begin{array}{r}£ 732,927 \\
450,596\end{array}$ & $£^{2,192,94}$ \\
\hline \multicolumn{5}{|c|}{ PUBLIC REVENUE } \\
\hline $\begin{array}{l}\text { ew South Wales, } \\
\text { ictoria, } \\
\text { ew Zealand, }\end{array}$ & $\begin{array}{r}f_{10,036,185}, 036 \\
8,343,588 \\
4,193,942\end{array}$ & $\begin{array}{r}£ 9,304,249 \\
6,887,463 \\
5,079,230\end{array}$ & $f^{885,288}$ & $£_{1,546,125}^{731,936}$ \\
\hline
\end{tabular}


In bank deposits, in the totals of trade in and out, and in the revenue payable by the people, between 189 I before the panic and 1897 after the panic, New Zealand alone shows a gain, with the exception of the exports of Victoria. New South Wales and Victoria fell backward.

This fact, that there was no panic in 1893 in New Zealand, must take its place with the other fact we have chronicled that, owing to the compulsory arbitration law, there has not been a strike or lock-out in New Zealand for five years, as two of the most remarkable achievements in the history of this remarkable country. 


\section{CHAPTER XII}

\section{"AND THEN WE SMASHED THE MONEY RING"}

ITs Advances to Settlers is the most characteristic feature of New Zealand's aid to industry. This began as a policy of Treasury loans to farmers on their land. It was initiated in I893, and has since been imitated by New South Wales, Victoria and South Australia.

The world over one of the greatest obstacles in the way of the small farmer-and the large one-is the difficulty of getting capital. Often there is no money to be borrowed in the district where he lives, or, if there is, it is in the hands of rich neighbours or banks, who know nothing but their bond and the pound of flesh. But in New Zealand the settler has only to go to the nearest post-office to get into communication with a money-lender who charges no commission or brokerage, and no fees, except for actual expenses, never exacts usury, offers no cut-throat mortgages for signature, will let him have any amount from as little as $\$ 125$ to as much as $\$$ I 5,000 , has never foreclosed, does not try to induce him to borrow more than he really needs, if he has no freehold will lend on leasehold and goodwill and improvements, gives him thirty-seven and a half years to pay the money back, and accepts it from him in small instalments of principal with every payment of interest, so as to make it as little of a burden as can be, will allow him, if he happens to have $\$ 25$ to spare, to pay it in at any time to reduce his indebtedness, and when it finds itself mak- 
ing a profit out of its business, instead of accumulating a fortune, gives him the benefit by reducing his rate.

When the New Zealand farmer goes to the post-office for his mail there faces him on the walls this notice:

\section{ADVANCES TO SETTLERS}

The Government Advances to Settlers Office Has Money to Lend

Upon Fixed or Instalment Mortgages in Sums of from $£^{25}$ to $£ 3000$

On Freehold or Ground Leasehold, for use for Agricultural, Pastoral, Dairying, or Market-Gardening Purposes.

Borrowers have the Right to Repay the loans Partly or Wholly

$$
\text { At Any Time. }
$$

Fixed Loans are Granted upon Freeholds for any Term not Exceeding Five Years, and Instalment Loans

FOR $361 / 2$ YEARS:

Interest Five Per Cent. with (in the case of Instalment Mortgages) an Additional One Per Cent. on Account of the Repayment of Principal.

All Costs very Low. No Commission or Brokerage Fees Charged.

This is the notice the South Australian farmer finds at his post-office:

\section{South Australia}

THE STATE BANK OF SOUTH AUSTRALIA

IS NOW PREPARED TO LEND MONEY

On approved securities at Four AND A HALF per cent. per annum, repayable by equal half-yearly instalments on April 1 and October I, extending over periods of from ONE 
to Forty-Two years. Borrowers have the privilege of paying off Any Portion or the Whole of the Principal, should they so desire, ON ANY rst of APRIL or Ist of OCTOBER, and when any portion of principal is paid off, the Interest is Reduced Proportionately.

Each half-yearly instalment contains a PORTION OF THE Principal, so that, at the expiration of the period for which the loan is granted, The Whole Sum is Paid OfF and the borrower is entitled to the discharge of his mortgage.

No Charge is Made for Either Preparation or Discharge of Mortgage, the Entire Cost to the borrower being the fees for registration.

Applications to be made to Mr. G. S. Wright, the Inspector-General of the State Bank, from whom further information may be obtained.

South Australia does a little better with its State Bank than New Zealand. New Zealand charges its borrowers five per cent. South Australia offers money at four and one half per cent., and makes no charge for either the preparation or discharge of the mortgage.

If our farmer needs some money the clerk at the window will give him a printed form on which to write his application. In reply he will perhaps receive a note like the following, which is a copy of one of the forms used by the State Bank of South Australia:

\section{THE STATE BANK OF SOUTH AUSTRALIA}

$$
\text { Adelaide, . . . . I89 }
$$

SIR: I have to inform you that it is very unlikely that the amount asked for in your application would be granted; and to avoid putting you to unnecessary expense I shall be glad, before asking you for a valuation fee, if you will in- 


\section{THEN WE SMASHED THE MONEY RING}

form me what is the least possible amount that will answer your purpose, and what you require the money for.

Yours faithfully,

G. S. WRIGHT, Inspector-General.

Mr.

Or perhaps his application is looked upon more favourably, and he gets this answer:

\section{THE STATE BANK OF SOUTH AUSTRALIA}

$$
\text { Adelaide, . . . . } 189
$$

SIR: I have to inform you that the Trustees of the State Bank have approved of a loan of . . . . on the security offered in your application, which will be available on the due execution of a first mortgage of the security offered.

To avoid delay, please advise when a settlement is likely to take place, so that a check may be in readiness.

$$
\text { I am, sir, }
$$

Yours obediently,

G. S. WRIGHT, Inspector-General.

Mr.

If the loan is made the New Zealand or South Australian farmer receives his money through the post-office; he makes his interest payments there; the whole transaction is made as easy and simple for him as possible.

When the decline of prices began in 1893 , after the panic which ravaged every country but New Zealand, the Australasian farmer had to sell in the world's market his butter, grain and meat at steadily falling prices, but the mortgage companies and banks would not lower their rate of interest on the money he had borrowed, nor would they make fresh 
loans at rates which corresponded to the universal shrinkage. They thought they had the advantage of position, and naturally they meant to make the most of it.

Whereupon the New Zealand farmer bethought himself of an advantage of position he had. He had the government, or, more accurately, he was the government, and its power he knew well by previous experience. He was democratic enough to believe that that power is never put to better use by the people than to increase the welfare of the people. The people pay the bills; they have the right to the benefit. The New Zealand democrat saw that he could use his power as a citizen to obtain for himself as an individual the advantage of the low rates at which government can get money. Thereupon he-that is, his Parliament-passed a law directing the Treasurer to borrow $\$ 15,000,000$ on bonds in London and loan the money so obtained to the farmers, market-gardeners and cattle men of the colony at enough of an advance to pay the expenses and accumulate a reserve fund for bad debts. As the Treasury of the nation could borrow money in London, in the international money market, at three to four per cent.- the price realised for the three per cent. consols sold in this case was $\mathfrak{f}_{94} 8 \mathrm{~s}$. $9 \mathrm{~d}$. for one hundred-it could loan it at five per cent. and make a handsome profit.

The New Zealand farmer is a very practical man. He enjoys being addressed at country fairs and political mass meetings as a "bulwark" and "mainstay," and "bone and sinew" and all that, but he also likes to see some substantial benefits accompanying these honeyed words.

In this case he did not take long to decide what to do, nor how to do it. The decline in prices began in the years immediately preceding 1893 . The Advances to Settlers law was passed in 1894, and the money was in hand in May, 1895. The preamble of the act read: 
"Whereas, by reason of the high rates of interest charged on the mortgage of land, and the heavy incidental expenses connected therewith, settlers are heavily burdened and the progress of the colony is much retarded, and

"Whereas, it is expedient that the government should afford such relief in the premises as is consistent with the public safety,

"BE IT ENACTED," etc.

Seven million five hundred thousand dollars were borrowed at first, and $\$ 2,500,000$ more have been borrowed since- $\$ 10,000,000$ in all.

The Conservatives opposed this project with unanswerable demonstrations that it must be futile, since the rate of interest is fixed by the "law of the market," and that government, which can "create nothing," can no more interfere with these laws than with the laws of the tides. But the result has proved that in New Zealand part of the "law of the market" is that the New Zealanders as a government can borrow money in London at three or four per cent. and then lend it to themselves at four or five per cent.

By an amendment of the law in 1899 , the owners of city and suburban property, at first excluded, are allowed to borrow this. "cheap money" under certain limitations. It is recognised that the industries of the towns are handicapped by usury as well as those of the country.

The business which has been done under the act is shown in the following statement furnished me by the officials:

Government Advances to Setrlers Office, New Zealand

Number of applications received up

to January $3 \mathrm{I}, \mathrm{I} 899 \ldots \ldots \ldots \ldots 878$

Amounting to ............. $\mathfrak{f 2}_{2,881,316}$ 
Number of applications on which, up to January 3I, I899, advances were authorised...........668 3 I

Amounting to..............

Number of advances authorised $£_{\text {I }, 994, \text { I I } 5}$ which were declined by applicants, up to January 3I, I899....... 808 Amounting to.............. Balance, being amount of advances authorised to and accepted by applicants (to number of 6023)...

$\mathfrak{f}_{369,295}$

$\mathfrak{f I}_{\mathrm{I}, 624,820}$

Note.-The amount authorised to and accepted by applicants $\left(£_{1}, 624,820\right)$ includes mortgages repaid and reinvested on mortgage.

In April, I900, the office announced that the number of loans had increased to over 7000, "and we have not lost one shilling. For the year there is not one penny of principal or interest uncollected." The amount advanced by the department has been \$10,000,000. The government supporters could well afford to ask in the last campaign: Where could the loan company be found that could show such a record as that?

The State Bank of South Australia has so far loaned $\$ 1,862,600$, and the amount of interest in arrears, March 31,1898 , on the transactions of several years was only $\$ 472$.

The citizens who voted for this to help the farmer got their own reward in a general reduction of their rates of interest and in a new prosperity. All over the colony rates came down with a run; not only the government borrowers but all the borrowers felt the benefit. A small group of capitalists were furious of course, but it is not this class which controls the administration of New Zealand. 


\section{THEN WE SMASHED THE MONEY RING}

The people have done more than make money by this financial "self-help." They have released themselves from a degrading servitude to the money-lenders. "They used to have to go," the Honourable J. G. Ward has said, "with their hats in their hands, and beg and beseech the few who had control of money before they could get it; they had to pay an extravagant rate of interest; not infrequently they were compelled to do their trading with the institution from which they got a loan. Now borrowers are sought after if their security is good, their rate of interest is low, and they are relieved of the despicable compulsion to deal with a business concern because they have secured a loan through it. The farmer now can sell his produce where he pleases."

A high official, one who has had a potent hand in this legislation and all the other recent progressive movements, gave a breezy explanation of the land and money legislation of 1892 and 1894 :

"We smashed the land ring by the land and income tax laws and by our land for settlement laws, and then we smashed the money ring by state lending. The two rings worked in with each other. The action of the state in entering the money market has made an average reduction of two per cent. on $\mathfrak{E}_{32}, 000,000$ of landed indebtedness, and $\mathfrak{f}_{32,000,000}$ of other debts. This is a saving of $E_{1}, 200,000$ a year to the country. In other words, the London loan of $£ 2,000,000$, which, at three per cent., costs the country 160,000 a year, is costing the people really less than nothing. There is a vast saving going into their pockets every year in greater comfort, independence and hope."

Here is a political economy which creates wealth by capitalising political brotherhood.

The official statement of the purposes of the law, in the New Zealand Year Book for 1899 , speaks with almost equal 
plainness. Referring to the general decline caused by the advances to settlers in the rates of interest throughout the colony the Year Book says:

"This result, while it may have diminished the incomes of a few persons resident within the colony has benefited thousands of deserving settlers and led to large areas of land being brought under cultivation that, but for the Advances to Settlers Act, would still be in their natural state."

"You would be surprised," a prominent member of the Ministry said, "at the small power of the moneyed men in this country. They can never get possession of the railroads nor telegraphs. The government competes with them in the rates of interest. They see the borrowers who need to come to them growing fewer. They do not dare to build up large estates."

The Premier of South Australia, too, in his annual speech to the people, in 1896 , emphasises the fact that the State Bank has forced capitalists, rather than lose their business, to "reduce their rates in a way that would not have been dreamed of but for this competition," and, he adds, "a good thing, too," with cheers from his audience.

The rate of interest charged on the advances to settlers is five per cent. a year, but the amount paid each six months is at the rate of six per cent. The extra one per cent. is repayment of principal. There are seventy-three semi-annual payments, so that the whole debt is cleared off in thirty-six and one half years. On a loan of $\$ 500$ the borrower pays \$I every six months for thirty-six years. The last payment is $\$ 9$.

On freehold property sixty per cent., on leasehold property fifty per cent. will be loaned by the state. Whenever a farmer has \$25 "to the good" in his pocket it will be accepted in reduction of his indebtedness, and he may pay off the whole at any time. The charges for examining the 
property and preparing the papers are all regulated by a fixed schedule, and are most moderate. No person in the Advances to Settlers office is allowed to take any fee or reward from any one seeking a loan. The average amount loaned is under \$I5OO. A considerable number of the borrowers pay before the money is due. Ninety per cent. pay within a fortnight. Two thirds of the borrowers wanted the money to pay off existing mortgages made with private parties at high rates. Absolute secrecy is guaranteed the borrower.

New Zealand went to the London market for its money, but the manager of the South Australian bank informed me that he got all his funds at home. He disposes of his bonds largely to savings banks and insurance companies. He sells his three and one half per cent. bonds in Adelaide at a premium and lends the money to the farmers at four and one half per cent. He saves by this use of home capital a considerable amount of interest money which in the case of New Zealand was wasted from the fact that the Treasury, after selling its bonds in the London market, was not ready for some time to use the proceeds, and these consequently lay idle. The advantage of the South Australian method is that the State Bank, when an application is approved, say to-day, sells the bonds to-morrow, and can pay over the money to the borrower the next day.

The operation of the New Zealand act has been so successful that the rate of interest is to be reduced. In his budget speech for 1899 Premier Seddon, after showing that on the last $\$ 2,500,000$ borrowed in London for advances to settlers the earnings were \$1 25,000 a year, although the money cost only $\$ 75,000$ a year, gave notice that he proposed to allow the people the advantage of this profit, and "reduce by one half per cent. per annum the interest charged upon advances to settlers." 


\section{CHAPTER XIII}

\section{GOVERNMENT AND COMPANY, UNLIMITED}

All the Australasian commonwealths are zealous seconds of their people in the international duels of the market. When the producer of Australia goes to Europe to sell his meats, wine, or wheat, in competition with all the other producers who rendezvous there, he has his country behind him -and before him, too, since it is awaiting his arrival, and has, in most cases, even instructed him in advance what to bring and how to raise it, and, as will appear, does even more than this.

The butter market of London is a colosseum of competition where, behind the individual sellers from Denmark, Canada, New Zealand, Victoria, the United States and France, are to be seen the governments to which they belong urging them on, telling them how to strike, and refreshing them between the rounds.

The United States Agricultural Department in 1898 issued 501 different pamphlets and gave them a circulation of over 7,000,000 copies. The country that does the least for its producers is the one whose farmers are being most completely competed out of their own market-England. No home market is enough for any community in these days of "expansion."

All the Australasian colonies are committed to the policy of backing up the industries of their people at home and in the foreign markets. Queensland has advanced money to 
build co-operative sugar-mills ; South Australia has its London export depot and state bank; Victoria receives, grades and ships fruit, butter, rabbits, tobacco and other things, and has a very generous system of bonuses. Boldest of all is the "cheap money" scheme of New Zealand. New South Wales does less than any other colony. It is more like England in its "let alone" ideas. But in the dry lands it is digging wells to supply the farmer with "cheap water," which is to him quite as important as "cheap money" to the well-watered New Zealander. All the colonies subsidise the miner and prospector or "fossicker."

Queensland gives a bounty on home-sold wool if home grown, and has two travelling dairies going about the colony for the instruction of farmers. But most important is the part it takes in the battle of the nations in the world's sugar markets. In proportion to its population of only 500,000 , this country's re-inforcement of its sugar producers has been the most generous of all. In 1885 the Queensland Parliament appropriated $\$ 250,000$ to be advanced for the building of sugar-mills for associations of growers who had no mills in their vicinity and no means to build for themselves.

One of the purposes of this legislation was to help in the solution of the great economic problem of Queenslandwhether sugar can be grown there as it is in New South Wales by white labour alone. It was made a condition of the loans that only white men should be employed.

In the first years the experiment was not very successful. The co-operators got into trouble among themselves, and their irritation against the management was so great in some cases that the members boycotted their own mills. The associations did not pay their interest to the Treasury, and, in defiance of the express stipulation of the law, they crushed cane grown by black labour. 
Still, in 1893 , enough had been accomplished in the opinion of Parliament to call for a wider effort. A new law, the Sugar Works Guarantee Act, was passed appropriating $\$ 2,500,000$ for the erection of sugar-mills, and in September, I899, the Minister of Agriculture declared himself to be in favour of a further appropriation of $\$ 2,500,000$.

The state derives large benefits from this policy. I found that it had been the means of settling hundreds of people on land in districts where only dozens were before; and this process of settlement is still going on. This increases the amount of taxable property, the growth of population and the business of the railroads, all of which adds to the revenue.

The policy has been popular with the farmers because there are a hundred and one contracts of all kinds for them and their teams, in connection with building and operating the mills. It has been popular with the labouring men and the radicals because of its co-operative feature, and because they saw in the development of co-operative sugar planting a re-enforcement of their campaign against imported coloured labour. Some of the large banks and landowners favour it because it increases the saleability of land.

Any group of Queensland farmers who wish to go into sugar-cane culture, and are not within reach of a mill where they can market their cane, need only get together and forward an application, asking that an official be sent to investigate and report. If he finds that their land is suitable and that there is enough of it, and that the farmers know their business and mean business, the project is sanctioned. The farmers must give their guarantee that the land will be kept in cultivation to a sufficient extent to provide employment for the mill.

The planters then incorporate themselves and make application in legal form for the needed amount of money. The 
plans of their mill must be submitted for official approval, and when this has been had, their lands and the mill to be erected are turned over to the government under a mortgage and bill of sale. On this security the Treasury advances the money, not giving it over direct to the association, but using it to pay for their mill. The construction is superintended by a state official, and "progress payments" are made only upon his certificate. While all these preliminaries of organisation, issue of debentures and building of the mill are going on, the farmers are clearing and planting their ground. The Treasury at first undertook simply to guarantee the bonds of these companies at three and one half per cent., but in practice from the beginning, and now by law, takes the debentures itself and advances the cash.

The latest returns, those for I899, show eleven mills to have been built under this plan. They have received advances of $\$ 2,324,805$ out of the authorised appropriation of $\$ 2,500,000$. They have a capacity of 48,000 tons of sugar in the season. The total product of the colony last year was 163,734 tons. They have made a net profit of $\$ 95,280$; have paid interest of $\$$ IOI,770, and up to June 30, I899, owed $\$ 182,225$ in interest, and $\$ 281,300$ on the repayments which according to law were to be made each year in "redemption" of the principal.

The percentage of profit earned by these mills varied from three and one half per cent. to twenty-two and one half per cent., the average being nine and one quarter per cent. In mitigation of the failure of the mills to pay all of the interest they owe, they plead the fact of a very heavy fall in the price of sugar and a succession for three years of bad seasons.

A hot controversy rages around the question of white against black labour. One of the effects of federation will be to put an end to the use of Kanaka or coolie labour on the 


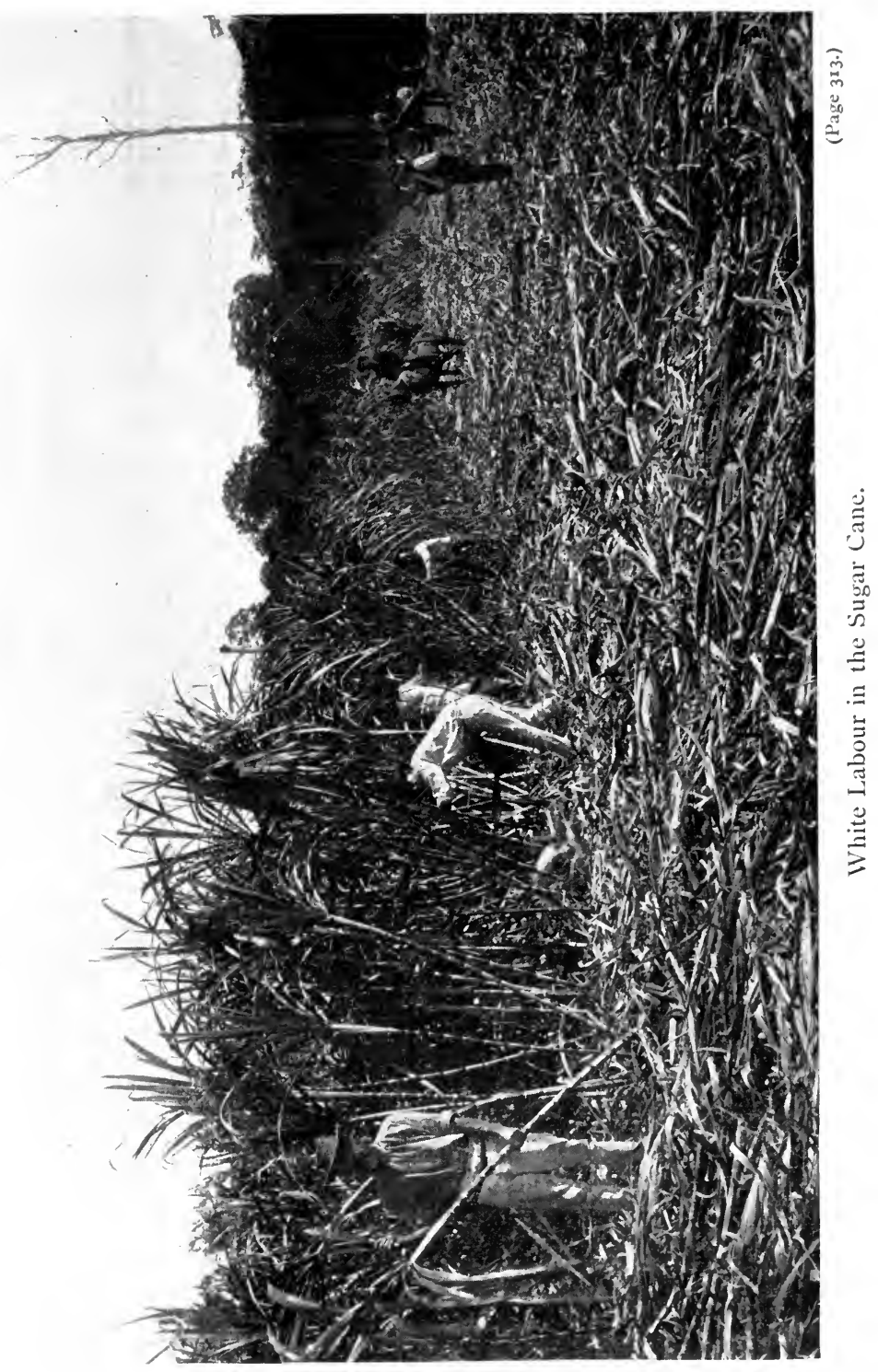



sugar plantations of Queensland. New South Wales raises its sugar with white labour, and will never consent that Queensland shall have the advantage of the cheaper labour from the South Sea Islands-if it is cheaper. On the other hand, in federation Queensland will get the benefit of a protective duty against foreign sugars. This will inure wholly to its advantage, as it alone of the colonies produces more sugar than it consumes. The intense "white" policy of Australian labour parties will make it impossible for Queensland to continue, now that federation has come, her importation of the Kanakas and coolies. Even before federation and without the help of the Labour Party in the other colonies, the Labour Party of Queensland has been able to impose so many restrictions on this black labour as to take away a very large part of the profit of it. $\mathrm{Mr}$. Michael Davitt has given some very interesting and accurate details in his book about this labour situation in Queensland.

The official returns show cases in which "free" Kanakas receive $\$ 750$ a year. Many draw from $\$ 3.75$ to $\$ 6.25$ a week, with housing and rations. They receive all this whether well or sick, and if sick, must be given proper medical attention. The black man is not allowed to plough nor drive a horse on the road, nor to work in the mills. This work is the privilege of the white man.

I found the officials of the Agricultural Department at Brisbane believers in the feasibility of cultivating the cane fields with white labour. They told me that the small planters who are going into these co-operative mills by the help of public money are cultivating their cane fields with their own and other white labour. They employ a few black men, but this black labour is decreasing, and it is thought will continue to decrease. The supply is small, and the black man is rapidly becoming sophisticated enough 
to get as much as the white man, and is, at the best, not as valuable as the white.

But Professor Skertchly, the State Geologist of Queensland and late President of its Royal Society, on the other hand assured me that it was impossible for the white man to live and labour in the tropics, and especially emphasised the impossibility of the white race propagating itself. $\mathrm{He}$ says that the statement that white men can and will labour in the sugar fields "is a political cry and not a proven fact."

"Tropical agriculture," he says, "requires not only a hot but a moist climate, and it is this steaming atmosphere with but little change of temperature which surely, even if slowly, undermines the vitality and energy of the white who unwisely attempts a style of life for which nature has unfitted him through centuries of education in less trying regions."

This question is wider than Queensland. Our Hawaiian and Philippine and West Indian accessions make it a burning issue for the United States. Benjamin Kidd, in his book on "The Control of the Tropics," insists that the white man cannot live and work and transmit himself in the tropics.

But Alfred Russel Wallace opposes this view in a most interesting contribution which he made to the "London Daily Chronicle" of November 2, 1898. As the result of twelve years in the tropics, spent in work, he says that it is "because white men as a rule do not work enough in the open air in the tropics that they suffer in health." They who "suffer most in the tropics," he says, "are women of the ruling classes," and they are the ones who do no outdoor work at all, and have the fewest outdoor occupations and amusements. He goes so far as to affirm that the tropics, on the whole, are more conducive to health than the temperate regions. They are, he says, the most lovely and 
most enjoyable abodes for the human race, for there it can live with the least amount of labour, and secure the greatest amount of leisure for the development of the higher nature. But the white man can do this only as a true settler, not as an exile and fortune hunter. He must not have his work done by hiring native labour, a more or less modified form of slavery, according to Mr. Wallace, but must work himself with his hands as well as his head.

With these results of his experience and observation before him, Mr. Wallace offers "as a clear and definite solution of "the problem of the tropics," that "they must be gradually occupied by' white men in co-operative association to establish permanent homes." And these, he goes on to say, "surrounded by the glories of tropic vegetation may in time become something like a legendary paradise."

At Hawaii I found the large planters fully conscious of the coming perplexities of their labour supply under the laws of the United States. Indeed these perplexities had already arrived. Some attempt has been made to fill the labour void by the importation of Japanese, but the experience at Hawaii has been the same as that which is indicated by the significant utterance of a Queensland planter, in an agricultural conference at Mackay, in Queensland, in June, I899, who spoke of the "intelligent, enterprising and undesirable Jap." The Jap is too intelligent and too enterprising to submit to the treatment which the Chinaman will bear without a murmur. The Chinaman never resists, but there comes a moment when the Jap takes his knife and goes for the overseer.

On the steamer that brought us back to America was an agent of a syndicate of Hawaiian planters coming to the United States to induce American farmers to settle in the islands, to grow sugar for the large mills.

In Queensland a similar movement is under consideration. 
One of the proposals discussed at the Queensland Agricultural Conference just spoken of, was a plan for the assisted immigration of farm labourers from England, Germany and other European countries.

"It is in Europe," said the principal speaker on this subject, Mr. G. W. Pott, "that we will find the labour we require. In Great Britain, Germany, Denmark and other European countries, we will find a class of farm labourers, thrifty, sober, industrious, accustomed to long hours of steady toil, and paid at a rate of wages in many cases below that paid by us to the Kanakas."

To crown the efforts to advance the sugar industry, it is proposed by some of the leaders in the Labour Party of Queensland that the colony shall establish a "state sugar refinery." This would refine the sugar of the planters at actual cost. The commonwealth would then act as a broker for the sale of the sugar it refined, and turn over to the producer all the profit less only a small charge to cover its outlay-“as South Australia does with its producers," one of these leaders said to me.

New South Wales gives no subsidies, but its sugar interests, as the statistics show, are prospering at about the same rate as those of Queensland. The colony of Victoria recently appropriated $\$ 250,000$ to establish a sugar-mill at Maffra, and subsidised the farmers to grow beets for three years, and when I was there the officials were sanguine of success. But since then comes news, in September, I899, that the mill has been closed. New Zealand was the first to subsidise the sugar industry. It has been giving bonuses and other help for twenty-two years, but nothing of value lias yet been accomplished.

Victoria is a protectionist colony; New South Wales, free trade. It is one of the paradoxes of Australia to see these two states, with policies so opposite, side by side, and 
both flourishing, so far as observation and statistics show, about equally well.

The credit of all the Australasian colonies is inseparably bound up with the ability of their people to obtain, by sales in foreign markets, the means to pay the taxes out of which interest and principal on the very heavy debts abroad must be met, to say nothing of the taxes to be paid at home. They have, therefore, all of them, taken hold with their people to make the export trade as successful as possible.

"It has been my business for years," the Under-Secretary of Agriculture at Melbourne said to me, "to sit here and think out what can be done to help our producers."

His department has established travelling dairies and model schools, and sent lecturers all over the country to tell the farmers how to take care of their milk, and how to get the best results in butter and cheese. The teaching was at first practical, now it is scientific.

Refrigerating cars were put upon the railway lines, cool stores were provided at the country railway stations, refrigerating chambers were built in Melbourne, and the department undertook to inspect and brand butter for export. A bonus of two to six cents a pound was paid for several years on all butter sold abroad for which the seller could show his receipted bill of sale. The industry has now been so well established that the bonus is discontinued.

In its cold-storage warehouses at Melbourne the government grades, packs and ships the butter. This cold storage was at first provided free, as it still is in New Zealand, but now a charge is made. At first no poor butter was allowed to be exported under the official brand, but lately what is called a "fire brand" has been adopted, under which inferior butter may be shipped for the use of pastry cooks.

Victoria acts as the representative of the shippers collectively in making contracts with the steamship companies for 
freight, and these contracts include the use of refrigerating chambers.

"A wonderful success has attended this help to the dairy interest of Victoria," the Under-Secretary for Agriculture said. "Victoria is now the largest exporter of butter except Denmark."

If butter from a particular factory has anything the matter with it, an inspector goes there and finds out what the trouble is.

Under the direction of the cattle inspector diseased cattle are killed without compensation to the owner, on the ground that such animals are of no value to the owner or anybody else.

The export business in poultry has been developed in similar ways. The size, weight, etc., of the shipments are officially regulated. The experiment has been a success, but not as successful as that in butter.

The government initiated the export of frozen rabbits. The Under-Secretary for Agriculture, looking about for "things that could be done to help the producers," saw in the destruction of rabbits a great waste of food. The rabbits are now received at cold-storage chambers, sorted out. and all those that are fly-blown and otherwise imperfect rejected. This inspection is carried on with incredible swiftness by men who have grown expert.

When I was in Melbourne there were 900 tons of frozen rabbits in the warehouses. The wholesale price which is received in London for these rabbits runs from sixteen to twenty cents each. This export and the requirement that landowners keep down the rabbits hold in subjection the pest which once threatened all the pastures of Victoria with ruin. What Pasteur failed to accomplish with his scheme of inoculation with contagious disease is being done by the demand of the markets. 
Victoria has sent to America for the best tobacco expert whom our Washington Agricultural Department could recommend to it, and he is now at work under a three years' engagement, doing all that he can to improve the tobacco culture of the colony. Under his advice the Minister of Agriculture has established an experimental farm to give instruction to the tobacco growers, and a bonus is being paid of several cents a pound on all tobacco sold abroad. A shipment of fifty tons had just been made when I was in Melbourne, and as much more was to be shipped the next week.

Fruit culture has been developed by the payment of a bonus to the growers of ten dollars an acre in gradual instalments, covering six years. A horticultural expert is sent around the country to teach the principles of the art. Attention is given mainly to the export of apples. These are shipped by the growers in ordinary crates to the cold stores of the department; they are then chilled to bring out the blemishes, after which they are sorted and shipped again in refrigerating chambers. Orchards are inspected regularly also upon request. If insects or other plagues are not removed according to directions, the growers are fined. The expert tells the farmers what trees to plant and how to take care of them. An analysis of soil is made for a nominal charge. This was at first made free until it was found that the analyses were asked for without being used.

Special hopes are entertained of the future of the wine industry. The state has established a school of viticulture and has started three vineries, and it also gives a bonus in case of the opening up of a foreign market.

An export of honey sent to London, under the auspices of the Agricultural Department, brought back the report from that city, unaccustomed to the peculiar flavour given by the eucalyptus, that "this honey might possibly be use- 
ful for medicinal purposes, but for no others." Not discouraged, however, by this, the export continues and is creating a constituency of its own.

In all its dealings with the producer, the rule of Victoria has been to let him choose his own agent in London, if he desired to do so. If not, it will undertake to find one for him.

A horticultural school started recently by Victoria was meant for men, but it was announced that if women wanted to come they would be admitted. To every one's surprise the school was at once flooded with women. Every seat was taken, and further admissions had to be refused.

Well-to-do women come because they want to learn enough to see that their gardeners do the right thing; poor women come to add another means of making a living; and a familiar figure is the factory girl who has been warned by her doctor that she must betake herself to an outdoor life, if she would live. There are lectures and practical work in gardens and orchards adjoining the school.

In I896 $\$ 775,000$ was thus spent by a people numbering only $1,100,000$ in the development of agriculture and mining. An allowance up to $\$ 2.50$ an acre is made to the lessees of pastoral land for improvements that add to the stock-carrying capabilities of the land.

The work of irrigation which in the United States is left to private enterprise has been taken up in Victoria by the state. A commission was sent some years ago to America to study the results of our experience, and, upon the publication of its report, Victoria embarked upon an extensive scheme. Up to I 896 the colony had already spent over $\$ 2,000,000$, and had plans which contemplated the expenditure of nearly $\$ 4,000,000$ more. This was in addition to an advance of nearly a million to private companies, to whom further advances will be made of several millions of dollars. 
The Mining Department in many districts sets up batteries at which it crushes ores for a small charge. Money is also advanced to companies and parties of not less than four miners for the prospecting and development of new territory.

To promote the growth of manufactures the Ministry asked the Commissioner of Railroads to carry coal at a uniform charge of a half penny a ton a mile. The commissioner, however, refused. It was no part of his business, he said, to do the work of other departments and develop the country at the expense of the railway department. The controversy was settled by an allowance made out of the Treasury to the railroad department of one farthing a ton a mile, which just saved the railway department from loss, and coal is now being carried at the rate of a half penny a ton a mile throughout the colony, the Treasury standing the loss.

One of the unique contributions of the state to the development of industry in Victoria has been the educational campaign. It set to work systematically to teach the people co-operation. Little pamphlets were printed and distributed throughout the colony reciting the methods by which co-operation had been made the wonderful success it is in England and in Continental Europe. Lecturers were sent out to talk to the people on the same subject. The result has been that the whole country is now dotted with cooperative dairies and creameries. There are joint-stock creameries also, but the co-operative farmers are doing much the largest part of the work.

Its free trade bias is shown in the different procedure of the colony of New South Wales when it followed the lead of Victoria and established a Board for Exports. This did not begin operations until $\mathrm{I} 897$, and has therefore not as yet achieved the results which have been noted in Victoria. 
New South Wales emphasises the fact that it does not buy or sell any article or produce on behalf of the owners. Its principal aim is to open neglected markets. It provides cold storage and shipping facilities very much as Victoria does, but everything of that sort in New South Wales "has to be paid for at commercial rates," the report says, "so that no undue advantages are given to exporters at the expense of the general taxpayer."

The state, in South Australia, makes advances to the producers on the value of their shipments, but the producer of New South Wales must look to private sources for such accommodation. Agents of the London merchants in Sydney make advances to the extent of half or three fourths of the probable selling value of products as soon as they have received the brand of the Board for Exports. A very considerable increase of prices is reported as one of the benefits which have been received by the producers from the establishment of this board.

The statistics show the benefit Victoria has had from its policy of bonuses on the export of butter. In the years I 888 and 1896 the exports of butter from New South Wales increased from 764,960 pounds to $2,707,088$ pounds, while those of Victoria increased from $1,202,649$ pounds to 22,I 70,790. The export went as high as $25,660,782$ in 1895 . but was cut down by the drouth.

South Australia follows Victoria in this policy of state aid to the producer, and has added to it a characteristic feature of its own called the Produce Export Department. This receives products at the ports of shipment in South Australia and disposes of them in the London market. The Premier, the Honourable C. C. Kingston, in his annual speech to his constituents, in March, 1896, said: "We thought that while throwing open the land we ought to enable the people to live on it and get a market for their products." 
The law for this experiment was passed in 1893 , and the work was begun in 1894. At the formal opening of the depot in 1895, the Minister of Agriculture, the Honourable John A. Cockburn, said that the liberal legislation for the settlement of the people on the land, and the work done by the Agricultural Bureau, with its innumerable branches throughout the country, and by the Agricultural College, was of little use if the producers were not somehow enabled to place their produce advantageously on the world's markets. It was for this reason that the depot was established, and the Minister of Agriculture predicted "that when the history of the colonies came to be written, it would be seen that no more important step than this was ever taken by any legislature, and that it was a step which, at no distant date, would be followed by all the other colonies."

"Before the state moved in this direction," he said, in an address in Philadelphia, in I899, "the small farmer or fruit grower was practically unable to reach the markets of the world, even if there was a great demand for his produce. The rates for freight and insurance were so high on small shipments that practically they were excluded. So the state stepped in and by grouping together the little rivulets of produce into one shipment, sends them forward at the lowest possible charges. The state in this way has brought the world's markets within the reach of the farmer and fruit grower.

"All the farmer has to do in South Australia, when he wishes to send a box of honey, butter, or some sheep abroad, is to write to the Agricultural Department, and if they are approved and forwarded, the farmer has nothing more to do but to sit at home and wait returns by check."

The department receives at Port Adelaide, in South Australia, for sale in London, cattle, rabbits, poultry, alive or 
dead, butter, grain, wine, honey, fruit, and any produce for which there is a prospect of a demand.

In fact, the state meets the farmer long before he comes to the doors of the receiving depot in Port Adelaide, for the railway station to which he delivers his stuff is its property - his property-and after he makes his delivery there the state does the rest, all the way to London and back.

At the opening of the Produce Export Depot, in 1895, the Minister of Agriculture pointed out that instead of conducting their business entirely with distant agents in England, as they had been doing, the producers could "now go into partnership with the agent-general in London and the manager of the London depot, who would act as principals for them, and would see that they got full justice and fair play. The government does the business at both ends," he said.

The men who raise the food and raw material of the world do well if they make a bare living, and the wealth somehow sticks to the men who sell it for them, but the Produce Export Department of South Australia is a commission merchant or broker who can have no secrets from its customers. The public accounts tell the exact story of all the dealings down to the last cent of the receipts and expenditures. Here is the only broker of whom the producers know that they get precisely what he gets, less the necessary cost of the marketing.

The commonwealth puts its fraternal arm about the farmer even before he goes to the railway with his shipment. Besides employing experts to tell him what to raise and how to cater to the customer, it analyses his soils and fertilisers, and supplies seeds and cuttings.

Minister Butler of the Agricultural Department, in an address at the $\Lambda$ gricultural Bureau Congress, in September, 1898 , speaks of how he sends inspectors who get samples of 
fertilisers from the dealers, which are then examined by an official analyst. The results of the analysis and the approximate fertilising value and any other papers which the minister thinks necessary are then published in the state's "Journal of Agriculture," together with the price which the dealers ask. There is no attempt to fix the prices at which the articles are to be sold, but the department means to see to it that the buyer shall know precisely what he is getting.

The much abused "state" does not seem to be wholly lacking in business ability. The report of its Produce Export Department notes that, during the summer months when there was little produce being brought in for export, the cold-storage rooms were rented out to butchers, produce dealers and others. This saved for them very large quantities of stuff which. otherwise would have perished, and it gave the department an income and enabled it to keep its employés at work instead of shutting down.

Democracy can do business at a loss and still make money. A homely illustration of this is shown in the operations of this export department with rabbits. It loses money on the rabbits which it receives, sorts, refrigerates and ships, as it charges the same price as is fixed in Victoria, where the business can be done much cheaper as it is very much larger. But the Minister of Agriculture points out that, though not directly remunerative, this business is remunerative indirectly. It gives employment for labour, increases the railway revenue, converts what has been a scourge into cash, and enlarges the capacity of the country to carry sheep. Were these rabbits not thus made a marketable commodity, they would be ruining some of the best lands in the colony.

"Individual enterprise" could not look beyond the immediate loss, but democracy, acting in this way, with one 
mind for the common good, is a larger sort of "individual enterprise." It fulfils Browning's fine definition of the people,

"A people is but the attempt of many

To rise to the completer life of one."

Animals may be delivered at the export depot at Port Adelaide, South Australia, either alive or slaughtered. If delivered alive, the department will see that they are properly killed, dressed, chilled, shipped and sold, and the government, which is not too big to do little things well, informs the producers that "when the slaughtering is undertaken by the department, the fat and skin will be returned to the owner," but "the remaining by-products become the property of the department."

South Australia will even receive ducklings, goslings, or any other kind of poultry alive, if the farmer so prefers, and will kill, dress, grade, pack, freeze, ship, insure, sell and remit, all according to a schedule of charges furnished the shipper in advance. It goes a good ways farther back than that in its care of the shipper. Not content with seeing that he ships no butter to London that is not up to grade, it goes back from the butter to the bull, in whose virtues the excellence of the butter must originate. In the report for 1898 the Minister of Agriculture notes the purchase of eight bulls, five Jerseys, two Ayrshires and one Holstein, which have been sent to various dairying centres. By 1899 there were twenty-three bulls stationed in different parts of the province. The town bull has long been a familiar figure in the agricultural industry of the world. Here we have the appearance for the first time of the "state" bull. Danton proposed a similar enterprise to the revolutionary government of France. 
Like Victoria, South Australia has stimulated the butter business by the giving of bonuses, and, in his speech in 1896 , Premier Kingston pointed out the effect of this butter bonus. Up to 1893 , when the bonus was given, the total value of the butter-sent to England had been only $\$ 6000$. The export in the two years since has been $\$ 550,000$. When he was giving particulars of the beneficial results of the working of the export department, he was interrupted by a voice in the audience, which exclaimed, "You will want a state ship next."

"Yes," the Premier replied, "to carry some people away."

Then, leaving the jest, he acknowledged that the colony had serious thoughts of supplying ships as an additional link in their facilities, and the same enterprise is under consideration in New Zealand.

Special efforts are made by South Australia to develop the sale of wine in London. The exports have increased rapidly, and the colony is now debating whether to subsidise co-operative wine cellars in South Australia, or to establish state cellars of its own.

The struggle to find a market in England for colonial produce runs up against serious obstacles in the trade customs of the mother country. The London agent of South Australia reports that he is unable to get the attention of certain houses unless he is willing to fall in with the "custom of the country" and pay commissions "varying in degree with the importance of the firm."

His efforts to market olive oil were blocked from the fact that the leading firms in London dealing in that commodity were interested in continental oils, and were not only unfavourable to any new competition, but would "crab" any other oils-a market expression which needs no elucidation to those who understand crab locomotion. They have "vested interests in their own goods to protect." 
The Agricultural Department of South Australia makes freight contracts for the shippers, and the Minister has stated that the Australasian colonial governments are all working together to secure reductions in freights and other charges.

The state puts its stamp "Approved for Export" on no wines or butter, or other things, without knowing that they are precisely what they pretend to be and what they ought to be. "If articles are inferior," says the Minister of Agriculture, "we have nothing to do with them." However, if rejected, the department does not withhold its further help from the unfortunate producer. It undertakes to sell for his account any shipment which it has rejected as unfit for export. His produce, therefore, is not thrown back on his hands as a total loss.

The success of the Produce Export Depot has been incontestable. Its business doubled in 1898. In a bulletin issued in February, 1899, the Minister of Agriculture announced that the storage capacity is to be increased at once to more than double, and that estimates and plans for new works with still larger capacity are being prepared to go into operation probably in the following year.

Best of all, the slight deficit of the previous years has been wiped out, and the returns of the business for I899 fulfilled the promise of the previous growth that the taxpayer will not be called upon to pay anything for the experiment. The first half year's work in 1899 shows a balance sufficient to pay interest at the rate of three per cent. on the investment, and there was a profit on the whole year's operations.

Through the export depot the producers get higher prices, and steadier-the South Australian apples sent to London through the depot brought the highest price of any marketed there. The Minister of Agriculture estimates that the export depot has added IOS., \$2.50, an acre to the 
value of all lands in South Australia fit for growing lamps, butter, wine and fruit. Following the same policy as that of New Zealand as to railway charges Minister Butler promises that as soon as the export depot "is able to pay anything like four per cent. interest above expenses its charges will be proportionately reduced. That is where the advantage of the state having the department comes in. In a department carried on by private enterprise you could not expect such a reduction, but we have no shareholders to whom a profit has to be paid."

South Australia advances money to the farmer at both ends of his labours. It lends him money through the state bank, as has been described, on his farm, and then, when his produce has reached the export depot, if it has passed the inspection and has been "approved for export," it will lend him money on the value of the shipment. In its directions to shippers the statement is made that "advances will be made on produce at the discretion of the Minister, interest being at the rate of five per cent. per annum."

Oceans of ridicule were poured on the agitation a few years ago, among the American farmers, to get the national treasury to advance them money on the security of their wheat, cattle and other products. The farmers were-and are-being bled to death by the elevators, commission men and railroads, and they wanted-and want-relief. That which seemed so preposterous to the critics of the farmers of the United States we find is in actual operation in many of the Australian commonwealths-New Zealand, Victoria, South Australia, Western Australia, for instance. These Anglo-Saxons are "self-helpers," if there ever were any.

There has been of course a strong Australian opposition to all this from those who believe that the government should perform none but negative functions, but even the most pronounced of these laissez-faire theorists are being 
won over by the indubitable success of the experiments. In defending this policy Dr. Cockburn, once Minister of Agriculture of South Australia, has said:

"If you bring hope into the life of the farmer and make him sure of his reward and that his profit will not be taken away from him you make him more efficient. Instead of sapping private enterprise we are assisting private enterprise. We are not anxious to organise patriarchal institutions, but fraternal ones."

This policy can be seen at work nearer home. The export business of Canada in butter and cheese has been increased by wonderful percentages. One cause is the very stern prohibition of spurious products, like filled cheese. Another is the direct aid given to the industry. Any one who wants to understand the subject of "Government \& Company, Unlimited," can do no better than to read the reports of the Canadian Commissioner of Agriculture. The Dominion makes loans to the farmers in Prince Edward Island and in the Northwest territories in aid of the construction of butter and cheese factories. It gives a bonus to creameries for a costly cold-storage plant in accordance with official plans.

The provinces of Quebec, Nova Scotia and New Brunswick also give bonuses, some of them considerable ones, to promote the erection of factories and creameries.

The government of Canada-which seems to have an "eagle eye," as well as "private enterprise"-further observed that the cheese factories, since they could make their product only in the summer, had to be idle during the winter. To put a stop to this waste of time, capital and labour, it undertook to teach the farmers that butter could be made in their cheese factories in the winter time, and to assist them, financially and otherwise, during the pioneer period. It gave the necessary instructions and contributed 
part of the money and machinery needed. To induce the farmers to go into this new departure of winter dairying the Dominion even undertakes to run the works itself at first, to push the sale of the butter, and to make monthly advances of money to the farmers on the value of their product.

Like Victoria, Canada acts as an evangel of the gospel of co-operation among the farmers, and puts in the full plants required for co-operative dairies. It usually finds the farmers reluctant in the beginning, but has invariably changed them into hearty supporters of the experiment.

In many districts the farmers are organising themselves and establishing co-operative dairies wholly at their own expense, provided the government will run them in their behalf during the initial period.

Of course "we cannot change human nature," but perhaps there are different kinds of human nature in the world.

The Dominion of Canada seeing, like the Australian colonies, that cold storage is indispensable to export and that export is indispensable to the modern producer, has for years been spending large sums to supply its farmers with cold storage on the railways and steamship lines in all directions. This was done, with Treasury help, on seventeen steamships between Great Britain and Montreal alone in 1897. One result of this intervention of "politics" was to perfect the refrigerator service, which had been such in name only; for "private enterprise" had been so careless and unscientific that instead of keeping its cold air around the contents of the cars it had been pouring it out along the tracks through leaky pipes.

It was New Zealand that originated the system of grading for export-and it grades for domestic use as wellwhich has been so widely adopted in the other colonies. This was at first opposed as "interference with the liberty 
of the subject." But the dairyman did not take long to find out that it was the gift of a new liberty to be told at once of defects in his butter, due to some carelessness or fault of the farmer or manager of the creamery. This makes it possible for him immediately to correct it and not go on shipping a poor article the whole season to London, only to learn, too late, that it had been found unsaleable there. The colony in addition provides cold storage for products for export, and makes no charge.

The grading protects the good farmer from the bad, the honest from the dishonest.

New Zealand was the first to give a bonus on export, which it did, in 1882 , by paying a prize of $\$ 2500$ for the first export of fifty tons of cheese. In the same year it gave the same prize for the first shipment of frozen meat.

It was also the pioneer in acting as the schoolmaster of co-operation. If the farmers of any district want to establish one of the co-operative dairies, of the success of which in different parts of the world they hear so much, the Agricultural Department will send an expert to look over the ground, and if he finds that there are cows to supply enough milk and that a sufficient amount of capital can be raised by the farmers, the department supplies, free of charge, plans and specifications for creameries and for the machinery. A recent law authorises the advance of money for the erection of creameries, provided the farmers find a proper proportion of the capital themselves, and applications are now being received for this purpose.

Flax grows everywhere in New Zealand, and a prize is offered for an improved process for treating the fibre. Bonuses have been given for the successful manufacture of new products - felt and other things.

New Zealand has under consideration a plan for a government warehouse in London. It maintains a produce 
commissioner in London, and he is urging that the colony should open at least one shop in each town of importance in England, solely for the sale of New Zealand meat. A still more ambitious suggestion comes from Victoria. Minister of Agriculture Taverner, after a visit to England to study the marketing of Australian products, has made a report recommending that the various Australian colonies should combine to erect large, cool stores at the London docks, to cost $\$ 1,125,000$, and also that they establish produce exchanges in various parts of London.

While doing his studying Mr. Taverner also did some business for his constituents. He arranged for direct steamship communication for the first time between Victoria and Manchester, and also got reductions of freights on colonial products averaging fifteen per cent.

The local authorities of New Zealand are empowered by Parliament to use their money to aid in the development of mining, and Parliament appropriates suitable sums to subsidise roads to the mines and to give rewards for the discovery of new fields, both to individuals and companies. The government has expended hundreds of thousands of pounds for races to supply water to the miners. It gets but small returns on this directly, but public enterprise has a broader basis than immediate profit. Counting in the sums received from miners for miners' rights and the gold duty and the amount of general taxes paid by the miners it has been figured in certain cases that the amount appropriated for this industry really pays nearly five per cent. a year profit, and public opinion in New Zealand sustains the expenditure as a whole as highly desirable for the general good. In 1897 the state appropriated $\$ 50,000$ for the purchase of a cyanide patent for the reduction of refractory ores in order to throw it open to the public at reasonable rates. 
New South Wales pays miners a certain bonus for every foot they go down. This is usually expected to amount to about half the cost of sinking the prospect hole. If the prospect is a failure it saves thousands of dollars that would have been spent in the neighbourhood by others, and if one prospect in many proves to be a strike the colony is amply repaid.

New South Wales also reduces ore experimentally for the public. It will apply every process necessary to determine its value and the proper way of treating it, and for this it makes a small charge. This is a work, as Minister McLachlan explained to me, which private industry could not undertake in the present state of development of New South Wales. The individual miner could not find out what to do. He would probably buy the wrong machinery or go in for the wrong process.

The huge water-pipe (of American manufacture) which has been laid by Western Australia to the gold mines of the Coolgardie district is one of the mining wonders of the world. Queensland, in aid of deep mining, will advance pound for pound on the expenditure by private parties, provided the experiment has the approval of the state geologist. In aid of ordinary prospecting it will advance ten shillings a week to each man.

The following is a specimen of the kind of "political" news which one finds in the New Zealand papers:

"The Agricultural Department has decided to make its first shipment of poultry to London in February. The department has arranged to kill and dress all birds sent to the depots, to be established at each of the four chief ports, and it will also be willing to send them to the home market at the risk of the owners. A small charge will be made for killing, dressing and packing. The cost of shipping the birds to London will be equally rcasonable." 
The people do not take this kind of thing as in any way a favour or privilege. No such idea of the relation between himself and his government ever enters the mind of the New Zealander. He is the government, and he expects it to do what he wants as if it were his hand.

I read in my morning paper of Christchurch:

"Considerable feeling was shown at the meeting at Marshlands last night with respect to the failure of the Department of Agriculture to fulfil their promise to send a trial shipment of onions to England."

And of course a deputation was appointed to call the department to account.

All this seems to be a good illustration of the origin of all the Australasian "socialisms." They have been the natural recourse of a new people coming into existence in the midst of the modern complex industrial system. Although in a new land the Australasians found themselves compelled to produce for the world's markets in sharp competition with the people of all other countries. They must pay interest and must buy expensive machinery and must live expensively. From every quarter of the globe other peoples are pouring products into the markets, with the help of the reaper, the binder, the railroad, and all the other now-a-day processes.

The primitive age of colonisation is past-the Robinson Crusoe age. With the natural shrewdness of the AngloSaxon, the Australasians have recognised this and have borrowed abroad and socialised at home. Colonisation in this age of the world cannot be the Pilgrim Father thing it was one hundred years ago.

One of the trusts or monopolies in New Zealand is the "shipping ring," which has drawn a cordon of high rates and poor service between New Zealand and the rest of the world. The people complain of this bitterly, for it produces 
some results very characteristic of monopoly. Coal is very dear in Wellington-\$9.25 a ton-because by some sort of "an agreement between gentlemen" the steamers from Australia do not bring in the cheap coal of that colony, and the New Zealanders are left to the tender mercies of the steamship company in control of their country, which also by a happy coincidence-happy for it-owns the principal coal mines in addition to the steamers. Its freight rate from the New Zealand mines to the New Zealand market is twice as much as that for bringing coal from New South Wales, several times as far.

An excursion to the Sounds of the West Coast, which are more beautiful than the fiords of Norway, is made every year by the steamers of this monopoly. The owners of a boat not belonging to this combination, thinking the sea was free and that they might as well make a little money in a dull season, advertised to carry tourists to Milford Sound. At this they were promptly notified by the monopoly that if they persisted in this invasion of "our field," it would at once put on a boat to compete with them in their own territory.

There are constant complaints from shippers of produce abroad of their treatment by the transportation companies, both as to rates and accommodations. The New Zealand government is continually interfering in their behalf and frequently secures important reductions. It has also subsidised steamers, but that has not worked satisfactorily. It cannot always see that full cargoes are ready, but the subsidised boats demand full pay nevertheless.

The Agricultural Department is now asking Parliament for power to enter into contracts with steamship companies in behalf of the producer. Premier Seddon, in his speeches during the last campaign, gave frequent instances of the active and successful intervention of the Ministry in behalf 
of better freight rates for the producers. As one item, it succeeded in getting the freights on flax reduced by $\mathfrak{f}_{3}$ a ton.

In opening the annual show at Dunedin, in I899, the Premier stated that he had been negotiating successfully for steamship communication with the Cape and even beyond, to India. In a speech just before the November election, I899, he said, referring to his success in breaking down the former monopoly and reducing freight rates, that, if the steamship companies attempted to get the same rates as formerly, he would stump New Zealand from end to end, and the result would be a line of government steamers for the carriage of New Zealand produce.

The price of coal in New Zealand was the subject of a Parliamentary investigation in I899. It was found that the "shipping ring" was complete and that there was no competition. The various ports were apportioned out among the different companies, like Roman provinces. Twice as much was charged for the shipment of coal to intermediate ports as to the principal markets like Wellington. The committee found that the price of coal could be reduced materially without any interference with the wages of the miners or the legitimate profits of the trade.

Besides suggesting some minor reforms the committee recommended "that the government take into consideration the advisability of procuring steamers for the purpose of conveying coal purchased by the government at the port of shipment," and the "opening of retail agencies under state control." The Opposition laughed at the idea that the state go into the coal business "as a huge joke," but the Premier took quite a different view $w_{\imath}$ of it. In the debate on the report he said, "The state can get screened coal for its railways at less than $\$ 5.00$ a ton, and why should the workingmen have to pay $\$ 10.00$ a ton? It will pay the state to buy coal at those rates and retail it from depots at $\$ 6.25$ a ton." 
The Premier was not afraid to point out where the policy which began in the purchase of coal must end.

"The time is not far distant," he said, "when the state will be working its own coal mines. I do not see why it should not do that as successfully as it works the railways."

Later, in a public speech dealing with future legislation, the Premier announced his intention of promoting a bill to fix the maximum price to be charged for coal. At the same time he promised a bill to regulate the rents for poor shopkeepers who were unable openly to take part in political organisations because of the pressure of their richer customers. Evidently the people regard Premier Seddon's programme with favour. In the election which soon followed,-in November, I899,- - he and his party were returned to power, for the third time consecutively, and with a larger majority than ever.

The old, too old, world is sterilising its wealth, its life, by the political economy of hell, into the deaths and debts and despotisms of war. The living capital of the international money markets that would reproduce itself in ever more and more harvests, commodities and homes we are changing into dead capital - armaments, soldier boys' graves and billions of government bonds to mortgage the many to the few for all time. But of the $\$ 40,000,000$ increase in the New Zealand debt since I89I, \$31,000,000 went into peopling the land, and railways, harbours, advances to settlers, etc. It costs $\$ 1,092,565$ a year in interest, and earns $\$ 1,434,350$. Eight of the other nine millions were spent for land and public works. Most of the last million was for debt refunding. Of the Australasian national debts of $\$ 1,064,859,095$ in $1897, \$ 907,389,505$ stand for railroads, water, sewerage, telegraphs, bridges, harbours, immigration, and most of the remainder - for "other works and services"-is equally fertile. 


\section{CHAPTER XIV}

\section{PENSIONS FOR VETERANS OF WORK}

IN the post-offices everywhere throughout Nev Zealand one sees on the walls a notice headed:

“OLD-AGE PENSIONS,"

giving directions for obtaining the forms with which applications for pensions must be made, and telling what to do with them.

The post-office is used extensively in the machinery of the old-age pension office. It supplies applicants with the necessary papers, forwards them, and receives from the Treasury and distributes every month the payments made to those who become pensioners.

New Zealand is the first country, and so far the only country, to pay old-age pensions out of the proceeds of general taxation.

Denmark began the payment of old-age pensions in I892, but there the funds are contributed only in part by the nation, which obtains them from drinkers, through a tax on beer.

In New Zealand every taxpayer contributes, since the money for old-age pensions is taken out of the consolidated revenue. In Denmark the "total abstainers" have no other national part in this measure of justice or generosity than to tax it out of the non-abstainers. 


\section{PENSIONS FOR VETERANS OF WORK}

The first payment of pensions under the law was made to the successful applicants shortly after my arrival in Christchurch. Punctually upon the opening of the door at nine o'clock the little corner of the office in the Post-Office Savings Bank Department set apart for this payment was filled with old men and women. Entering with anticipation and not infrecitentiy anxiety on their faces they came out in happier mood.

The measure was denounced in Parliament as one that would be invoked only by paupers and loafers, by the dissolute and the drunken. But no such words would fit the old and forlorn men and women I saw in the magistrate's courts undergoing examinations for pension allowance. There were signs of self-indulgence on the faces of some, but the great majority bore only the scars of suffering, privation and failure. Out of fifty or more, I saw only one who could have sat for the portrait thus drawn by the opponents of the bill, and he was peremptorily rejected.

Woman suffrage came in New Zealand almost without notice and without agitation. Old-age pensions were discussed in and out of the New Zealand Parliament for several years. Woman suffrage has cured no old problems, and, so far, has created no new ones. A slightly larger percentage of women than of men exercise their right of voting. The influence of women has been felt helpfully in legislation; it was due to this that instead of being absolutely forfeited the stipend of an old-age pensioner convicted of drunkenness or other minor offences has been made payable to his wife or some guardian.

As early as 1892 Dr. Duncan McGregor, who is at the head of the charities of New Zealand, urged some substitute for the relief given by the charitable-aid boards. He pointed out that the drift of legislation and debate in Germany, Denmark, England and other countries indicated 
the rise of a strong public sentiment "in favour of a more sympathetic, discriminating treatment of the aged poor. The idea is that the respectable poor ought not to be treated as thriftless spongers and broken-down drunkards, but rather as worn-out soldiers who have deserved well of their country. Our unjust system of distributing the proceeds of labour, it is argued, must compel society to face the duty of making such provision for deserving old age as shall not involve any sacrifice of self-respect in accepting it."

The Progressive Liberal Association, which has been the source of much of the energy that is actualising itself in New Zealand legislation, took up old-age pensions. Like the head of the Department of Charities, it emphasised the argument that something better than poor relief was due the victims of our "system of cut-throat competition." These radicals, however, insisted and still insist that pensions should be made universal, so as to avoid all suggestion of pauperism in the recipient, and the same demand was made by the Trade and Labour Conference of the New Zealand trades-unions in 1900 .

In the elections of 1897 candidates for Parliament were asked everywhere throughout the colony whether they were in favour of old-age pensions, and they almost always answered that they were, the Conservatives adding, "if" any way could be devised for making them practicable.

The "squire" class, which foresaw increased taxation for their lands, incomes and inheritances-and this, indeed, the friends of the scheme freely promised them-fought it most bitterly. Their first move was an attempt to convert it either into a compulsory insurance fund, in which no one should share who had not previously contributed, as had been done in Germany, or to make it universal-which is now the favourite English checkmate for this reform.

Discussion led to a decisive rejection of the universal and 


\section{PENSIONS FOR VETERANS OF WORK}

contributory features. To the argument for restricting pensions to those who contributed, Premier Seddon replied:

"All our aged colonists have contributed; they have contributed large sums to the colony's revenue."

He pointed out that property throughout the colony had been greatly enhanced in value, sometimes one thousand per cent., by the railroads and other public works built by the expenditure of public moneys, the interest on which these old colonists had helped to pay.

No contributory scheme, again, could meet the needs of those for whom immediate relief was demanded. They could not contribute. "The days of their youth and the days of their earnings are gone," the Premier said.

The case for these contributors is summed up in the preamble of the law:

"Whercas, it is equitable that deserving persons, who during the prime of life have helped to bear the public burdens of the colony by the payment of taxes and to open up its resources by their labour and skill, should receive from the colony a pension in their old age. Be it therefore enacted."

Great support came to the bill from the undeniable fact that many of the pioneers of New Zealand, men and women who had built their youth into its wealth and progress, had failed, from sickness, miscalculations, the rascality or weakness of others, to share in that prosperity. It was felt to be a cruel mockery to print "glowing lives" of these pioneers in the newspapers, and glorify them in anniversaries and semi-centennial celebrations, and still leave them suffering, as many were, for the bare necessaries of life.

How entirely New Zealand, with all its advantages, is in the same economic current as the rest of the world, with the same problems and disabilities in kind, if not in degree, was shown in the debate by the Honourable J. G. Ward. 
"The vast majority of our workingmen," he said, "are casual labourers. They have no certainty from day to day of their incomes; they have a positive certainty only of their outgoings."

The stock argument that these workingmen should practise thrift and pension themselves was answered by one of the members of Parliament.

"I should like to know," he asked, "whether the honourable member has ever visited the homes where workingmen are endeavouring to support their families on six slillings a day, and even then their work intermitterit. Out of that six shillings a day one third has to go to rent. They have to keep their families out of the small residuum after the landlord exacts his dues. He would find in these homes hungry children, women at the wash-tub, frigal meals and very few luxuries. I would like the honourable member for Wellington City to go into these homes-and they are numerous in the city from which he comes-and tell those inmates, 'You must practise thrift.' Thrift out of four shillings a day, with perhaps eight or nine mouths to feed, clothes to find, boots for their feet and books for their school! Thrift on the miserable wages that some of the employers of labour give to their young men because they will not keep old men, nor will they keep married men, some of them!"

That this was a true revelation of the New Zealand economic situation was confessed in conversation by the head of the Public Trust office. How can a workingman, he said in substance, who works hard and raises eight or ten children, feeding, clothing and educating them, housing them decently, lay by anything for a rainy day or old age? He cannot, and so we give him an old-age pension.

"If such a man," one of the New Zealand radicals to whom I quoted this remark said, "cannot, like the ant or beaver, gain a store for his winter of life, there is something 


\section{PENSIONS FOR VETERANS OF WORK}

'rotten in Denmark.' To burn him out before his time, creating the wealth of which the state boasts in its Year Book, and then invite him to act the part of a happy old age on a shilling a day, seven shillings a week, when even the ordinary workingman has to pay fifteen shillings a week for his 'tucker,' is pretty poor charity and no justice at all."

It was on this ground-that the workingman cannot be sure of making his own provision for old age-that the last English Trades-Union Congress voted for an old-age pension law. Their resolution favoured pensions at sixty years of age, or-a very important improvement on the New Zealand law - at the datc of becoming incapacitated.

The desperation of the opponents of the bill was fed by the forecast its supporters gave as to how they expected to raise the money. The Premier's chief supporter in the debate, the Honourable J. G. Ward, who had been Colonial Treasurer, predicted that the old-age pensions would become so popular that the people would insist that the funds to meet them be made sure by having certain taxes "earmarked" for them. "They would not be content to have them left merely as a charge on the general revenue, for that would put them at the mercy of a panic with its deficit, or a careless appropriation bill. He said that "certain classes of luxuries now imported through the customs could and should be specially earmarked" to provide funds to place the old-age pensions beyond the possibility of failure. He thought, too, the graduated land-tax might be "earmarked" for the same purpose. Old-age pensions, he declared, would be continued by the people of New Zealand, and would go much further than in the pending law.

The opposition was the most determined, not to say virulent, that has been encountered by any of the advanced proposals of the present administration of New Zealand during its ten years of office. Over nine hundred speeches were 
delivered against the bill as first proposed, and over fourteen hundred against it when submitted to Parliament the last time. Obstruction went to the extremest lengths that could be devised. Single members of the Opposition made as many as one hundred speeches against it, saying anything and everything that could consume time so as to break down even the physical strength of the government majority. This sort of tactics is called a "stone wall" in New Zealand, and to meet it the Premier and his supporters, refusing to adjourn, sustained the strain of a continuous session from Wednesday till Saturday night, when the Opposition finally gave way, and the bill was passed by a handsome majority.

The backbone of this resistance came from those who saw that in a not distant future their "unearned increment" would be taxed heavily to provide money to sweeten the lot of the old age which had helped to create it.

"Those best able to bear it," Mr. Ward had said frankly, "will have to contribute in proportion to their income and their position to this old-age pension fund."

To those who objected to the principle of the bill the Premier gave this reply:

"Some years ago when a quarter of a million was asked because Providence had sent disastrous snow storms in the North Otago and Canterbury districts, destroying large quantities of stock and causing much loss to the flock owners, this Parliament passed legislation in two days which gave relief to that extent. We allowed a reduction to the extent of $\mathfrak{f}_{400} \$ 2000$, a year in some cases to our Crown tenants. As disaster had overtaken them we relieved them of their obligations. Disaster has overtaken many of the aged of our colony; they have fallen in the industrial struggle. The state has a perfect right to relieve them by granting them pensions." 


\section{PENSIONS FOR VETERANS OF WORK}

This was the last word of the debate, and the bill then became a law by a vote of twenty-five to fifteen. This was in 1898 . The law was limited to three years, as so new a policy would by that time need amendment. The overwhelmingly Liberal cast of the new Parliament which meets in 1900 makes re-enactment certain. This law in New Zealand comes, after one hundred and two years, to realise the scheme broached by Tom Paine in a pamphlet published by him in I796. Under the title of "Agrarian Justice" he proposed that every nation should create a fund to pay to every one upon arriving at the age of twenty-one the sum of $\ell_{I} 5$ to begin the world with, and to pay also $\mathfrak{f}_{\mathrm{I}} \mathrm{O}$ a year for life to every person of the age of fifty years, "to enable them to live in old age without wretchedness, and go decently out of the world."

Through the courtesy of Stipendiary Magistrate H. Eyre Kenney, I sat by his side on the bench one morning in Wellington during his examination of thirty or forty old men and women. As the proceedings went on he explained to me the details of the law.

Any one over sixty-five is entitled to a pension, if otherwise qualified as specified by the law. Within certain limits of time there must have been no dishonourable imprisonment, no desertion of husband or wife or children, and for the last five years there must have been a sober and reputable life.

The Denmark law separates the deserving poor from the undeserving poor. The title of the New Zealand act limits it to "deserving persons," but the New Zealand interpretation of deserving is much more generous than that of Denmark. In Denmark no one who has ever undergone sentence for any dishonourable transaction or whose poverty is caused by his having been a spendthrift or who has received poor relief can have a pension. 
But New Zealand forgives the sins of the thriftless, the vicious, and even the criminal. This Christian spirit of democracy was voiced by the Honourable J. G. Ward in the debate. "Those who fall," he said, "may mend. Fortunately the great mass of the people possess the spirit of forgiveness." One may become a pensioner who has been drunk and disreputable, provided that these eccentricities of conduct have not been in evidence for five years previously. One may have been in prison for five years for a dishonourable crime, and still be eligible if the inprisonment was twenty-five years before. He may have been imprisoned for four months four times for offences punishable by twelve months' imprisonment and still be eligible for a pension if his incarceration is twelve years past.

To be poor in New Zealand is evidently the largest part of the qualification of "deserving." If a man or woman has been a citizen and resident for twenty-five years the pension is given as a right, subject to the stipulations just described. In other words, if the sheet is clean of drunkenness and idleness for five years, of minor offences for twelve years, and of the most serious ones for twenty-five years the pension will be given, no matter how black may have been the previous record. As usually inculcated, love of country is love that goes to one's country. Here is love of country from one's country.

In New Zealand, as in Denmark, the pension is forfeitable. The forfeiture of the pension is absolute upon conviction for twelve months or more for any offence "dishonouring in the public estimation," or for conviction of habitual drunkenness. Instructions while I was there were issued by the Commissioner of Police to the police throughout the colony to report on all cases where pensioners squander their pensions on drink, and not to wait until the pensioners had been convicted of drunkenness. The forfeiture 


\section{PENSIONS FOR VETERANS OF WORK}

is discretionary if the pensioner has been convicted only of a minor offence, and also if he is wasting his pension, injuring his health, or disturbing the happiness of his family. In such a case the pension may be paid to his wife or some one else for the family benefit. The latter stipulation is to be credited to the influence of the women and the franchise which has enabled them to give political effect to that influence.

The pensions are awarded only for a year. At the end of each year the pensioner must again make application and must undergo examination. There can be no doubt that this ordeal of examination, yearly repeated, keeps away some of the more sensitive.

In New Zealand, as in Denmark, pensioners are not disfranchised, as are the recipients of poor relief in England. To receive an old-age pension it is not necessary to be a pauper. Any one with an income short of $£_{52}$ (\$260) a year, or with property of less than $\mathfrak{f}_{270}(\$ 1350)$ may receive a pension. The full pension is $\mathrm{f}_{\mathrm{I}} 8$ a year, payable monthly, but no one can receive as much as this who has a larger income than $\mathfrak{E}_{34}$ a year or property worth more than $\mathfrak{f}_{50}$ in excess of incumbrances. For every pound of income over $£_{34}$, one pound is deducted from the amount of the pension. In like manner for each $£_{1} 5$ of accumulated property above $\mathfrak{f}_{5} \mathrm{O}$ in value, after subtracting any mortgage, one pound is deducted.

The ideal of the law is that the worn-out veterans of work shall, with the help of the state, have an income, if possible, of $£_{52}$ a year. To such a one, therefore, who already possesses $\mathfrak{E}_{34}$ of income the state pays $\mathfrak{f}_{18} 8$ more, making the $£_{52}$, which is the minimum set by New Zealand as the income which it thinks the old soldiers of the industrial army should have.

The court room on the morning of my attendance was 
filled with a pathetic crowd of men and women, ruined hulks, flotsam and jetsam of the work-a-day life of New Zealand. Some were from one of the benevolent homes which are maintained by the colony for the relief of its aged poor. These are not barred from receiving pensions, and they are also allowed to remain in the institutions if they desire, but in such cases the trustees appropriate part or all of the pension to pay for their keep.

There were old soldiers-in another court one of the applicants was an Eighteenth Royal Irishman, who wore a Crimean medal, with clasps for Alma, Inkerman and Sebastopol, and also Turkish and New Zealand medals-miners, sailors, workingmen, and wives and widows of the same classes. The examinations proceeded rapidly, from two to four minutes being taken up with each case. Sometimes husbands and wives were present together, and if their cases fulfilled the requirements of the law each went away happy with his allowance of a full pension of $£_{I} 8$ each. An officer of the home was in attendance for the purposes of assisting the judge in the examination of its inmates.

One applicant was receiving six shillings a week from this benevolent home. He was allowed a pension of $\mathfrak{f}_{1} 8$, $\$ 90$, a year, or seven shillings a week.

"The home will now reduce his allowance," the judge said to me, "or take it away altogether."

John Smith was an old soldier. He had been through the Waikato wars and had seen eight years of rough service. The judge looked at his certificate of character.

"You have," he said benignantly, "a very good character indeed."

The old man's lips trembled and his eyes filled with tears.

Of the next, a brisk little old man, the officer from the home said:

"This is one of those men, your honour, who goes away 


\section{PENSIONS FOR VETERANS OF WORK}

for several months in the summer to look for work in order to take himself off the town. He is the most independent man in the world, sir. He went away last summer as usual, but had to come back since he could find nothing to do."

Of another the officer said:

"He is an industrious man when able to get work, and when at the home he looks after its washing."

Some novel questions arise between the inmates of the benevolent homes who receive pensions and the authorities. In one case, at Taranaki, the inmates who received pensions took up the position that they were not paupers, since they paid the board for their keep, and therefore they struck against the regulation requiring them to work. This kind of strike is not covered by the compulsory arbitration law.

In one home some of the inmates had transferred their real estate to the charitable aid board. When subsequently they were granted pensions they asked the board to continue making them the usual grant or return them the deeds of their property. But the board, while deciding that it would not continue the charitabic aid, since they were now getting old-age pensions, at the same time refused to return the property which it held for them. It was afraid that, as the pension law was limited to 1902, it might not be renewed, and the old people would come again on its hands. The pensions make a saving in some districts of three quarters of the sums previously spent by the benevolent homes.

There were laughable and affecting lapses of memory in some of the old people. One could not remember where he had registered the birth of his last child. The dates of marriages were often forgotten, and the dates of arrival in the colony. A grave-digger when asked as to his income during the past year could not tell, because he was "paid by the piece," and he had forgotten how many there had been. His case was adjourned to enable him to find out. 
There were one or two who were too sick or too old to come. They had been visited by an officer of the court, and he made a written report on their cases, upon which the magistrate acted as the circumstances required.

An old woman trimly dressed, with red cheeks and bright eyes, took the stand and kissed the Bible briskly. They all kissed the Bible, an unsanitary proceeding but helpful to the finances of the government by shortening the lives of some of the pensioners. The judge, always kind in his interrogation of these unfortunate people, was more so than usual to this old lady, so prepossessing in every aspect.

"I am obliged to ask you," he said- "the law compels me to do so-if you have ever been in prison. I anticipate your answer," he added encouragingly.

The papers told of one case in which a judge, more considerate even than Judge Kenney, hearing the case of an old lady whom he knew to be of irreproachable character, tried to get over the difficulty of asking if she had been in prison by inquiring in an off-hand sort of way:

"Have you ever been in any trouble or bother?"

The old lady beamed on the bench through her spectacles and innocently answered:

"Well, I had a sprained ankle for six weeks some time back, and no one in the house with me."

So the judge had to repeat his question in the stern language of the act.

One of the old men, one of those from the benevolent home, when asked if he had ever been in prison, replied in an ostentatiously loud voice, "Yes, for thieving." Thereupon the officer from the home explained how this old fellow had walked off in the clothes given him by the institution, and had been brought back and jailed, just to make an example to prevent others doing likewise. He was allowed the full pension. 
Only once did I see among the would-be pensioners any one really looking disreputable. He was a vagrant of the most undeniably chronic type. He admitted cheerfully that he had been in prison, but, he urged, "never for any crimmal offence." He had been turned out of the home for drunkenness.

"What else can a man do," he demanded, "if he is turned out, but turn vagrant?"

"I shall have to search the criminal record," the judge said. The man stood aside while the court officials went to look him up. They soon returned with a long sheet full of a formidable list of convictions. Some of them were for particularly unsavoury offences. The application was summarily rejected. The man stepped down with a cheerful face, apparently as clearly satisfied as the judge that he had been properly rejected. "That," he said, referring to his record of convictions, "was an impediment, I knew; but as I was an old colonist I thought I might as well make the application." After this applicant had thus shown the courage of his "convictions" one of the old naval veterans took the stand. Asked the question about prison, he replied, "I have never been in prison more than twice. All hands went to jail in 1846 for deserting."

"That's an old story," said the judge. "The law does not look farther back than twenty-five years."

When the pension was granted some thanked the judge, often with tears in their eyes; some went away without a worl; some inquired eagerly, "How will I get it?" and were barely satisfied when told.

The proceedings were quite informal in their manner, and there was no touch of sternness to confuse the poor creatures. Everything that the judge could do by tone, manner and suggestion to assist them to recall the longforgotten details of age, marriage, income was done. 
When the name of George Nelson was called the officer in attendance informed the judge that he had died since his application had been put in.

The age of some of the old people was extraordinary. One old man-of-war's man was ninety-six, and a dame appeared with documentary evidence to prove that she was one hundred and ten years of age. Sometimes when there was no other proof the judge settled the question by telling the applicants that they "looked it." This was perhaps the only occasion on which I ever saw a woman show pleasure at having her age recognised.

Family Bibles play an important part in determining ages. To be able to recollect the death of King William and the accession of Queen Victoria is a card which the pensioners like to be able to play. One old woman declared her Bible was too big to bring along. She was sent away by the judge with instructions to bring it, even if she had to fetch it in a wheelbarrow, or a perambulator, or something.

In one case where the magistrate asked the witness how long he had known the applicant, the witness replied, "Eighty-one years, your worship."

"How long?" asked the astonished magistrate.

"Eighty-one years," was again the reply. The witness, who was eighty-six, remembered seeing his friend, now eighty-two years of age, wheeled about "in a sort of box on wheels when he was a littie baby."

A full pension was granted to a man one hundred and two years of age. Among other witnesses, his claim was proved by a daughter aged fifty-one, who said that she had brothers over sixty. This hardy old man had, in early life, been a shepherd in the Scottish Highlands.

An old settler and his daughter both applied for pensions and received them. The father was ninety-five years of age, and the daughter over sixty-five. 


\section{PENSIONS FOR VETERANS OF WORK}

There was a case of retribution, long delayed but sure. A widow in her application had stated her age as sixtyseven, but according to her second-marriage certificate. which she had to produce, she was only sixty-four. The court informed her that she could not be sixty-four to be married and sixty-seven to be pensioned at one and the same time, and the too youthful widow was told to wait.

In another case a birth certificate tendered in evidence to fix the age of a woman showed to the quick eye of the judge an alteration in one of the figures. The deputy wired to the district officer for the exact figures. The information was returned, and the lady lost her annuity.

The inquiries as to property, income, money in the savings bank, etc., were always thoroughly made, as they are required to be by the law. Many had incomes and owned property, and still received pensions of larger or smaller amounts. Some of the answers were:

"I had some property a few years ago."

"I earn about seven or eight pounds a year. I get my keep for doing light work."

"I never had any property to give away to get the pension."

"No income at all."

"No earnings last year. I earned something before that as a nurse."

"I have earned no money for two years."

"I have lived on my children."

"I lost what I had through sickness."

"I had saved some money and have been living on that. Now I have only $\mathfrak{f}_{2}$ ros. left."

"My wife takes in a few boarders; just makes enough to keep us going."

"I live with my daughter. I took in $\mathfrak{f}_{4}$ last year for sewing." 
The only property most of them had was their character. This, if vouched for by some responsible citizen, earned them an income from the state when all other sources of income had failed.

"Where is your savings-bank book?" the judge asked. The old man did not have it.

"You ought to have brought it in," said the judge, "and also your income tax return."

Applicants for pensions with post-office savings-bank books, income tax returns, mortgages to pay, and insurance policies are certainly a novelty. This case was postponed, as the judge said, "for search as to the value of your property, and for an investigation of your savings-bank book."

An applicant who had $\mathfrak{f}_{I 00}(\$ 500)$ in the savings bank still got a pension. If the amount had been only $£_{50}$ he would have been entitled to the full pension of $£$ I 8 , for up to $£_{50}$ of clear property or $£_{34}$ a year of income no deduction is made. As in this case there was an excess of $\mathfrak{t}_{50}$ over the $\mathfrak{f}_{5} \mathrm{O}$ allowed, and this $\mathfrak{f}_{5}$ o contains three complete sums of $\mathfrak{E}_{I_{5}}$, there was a deduction of $\mathfrak{f}_{3}$. This left him $\mathfrak{f}_{5} 5$ of pension, which he was duly allowed.

"You are not entitled to a pension," the judge said to one applicant. "Your income last year was over one pound a week."

"Thank you, sir," the man said as he stepped down. "It shall not happen again."

That they had relatives able to support them did not debar persons otherwise qualified from the receipt of the pension. That people attempt to take advantage of the law to relieve themselves of the burden of supporting indigent relatives is certainly true, but the courts can and do compel them to continue to contribute even after the pension has been granted. In one such case the magistrate said:

"If your sons think they are going to get out of support- 


\section{PENSIONS FOR VETERANS OF WORK}

ing you because you have an old-age pension they will find themselves in the wrong box. They have yet to reckon with me."

Where five sons had been voluntarily contributing eight shillings and sixpence a week for the support of their father, the court ordered them to continue to pay him one shilling a week each, so that his income would be twelve shillings a week, including his pension of seven shillings.

A woman who had received a pension of seven shillings a week continued, by order of the magistrate, to receive sixpence a week from each of her two sons.

A husband and wife appeared who had charge of a schoolhouse, he as janitor and she as charwoman. They were helped by their children. Sometimes it took four of the family to do the work. The father made $\mathfrak{E}_{1} 3$ a year. His wife earned $\mathfrak{E}_{\mathrm{I} O}$. As the income of neither of them was $\mathfrak{f}_{34}$ a year each received the full pension of $\mathfrak{f}_{1} 8$, the wife getting the same as her husband.

No pensions were given to married women until they produced proof of the amount of their husband's income, if any. If this was greater than $\mathfrak{E}_{104}(\$ 520)$ neither would get the pension. If it was less than that each would be entitled to a pension with the deduction already explained.

In Christchurch I saw the case of a woman whose husband was earning $£_{7} 8(\$ 390)$ a year. By the law, in considering an application for pension for a wife the income of a husband is halved between himself and his wife. The income of each of this couple was therefore considered, for the purposes of the act, $\mathfrak{E}_{39}$ a year. They therefore were both entitled to a pension of $E_{1} 3$ a year, making their total income, private and public, $\mathfrak{f}_{52}$ a year each, or $\mathfrak{f}_{\mathrm{IO}} \mathrm{f}$ for the two.

"A nice little income, truly," said the judge.

The man who admitted that he had drawn all but $\mathfrak{£}_{50}$ 
of his money out of the savings bank and given it away, "as he thought that he had too much money," was rejected on the ground that he had deprived himself of property in order to qualify.

One of the newspaper humourists of New Zealand explained the omission of a contemporary to publish the names of old-age pensioners in his district, as is done usually by all the newspapers, on the ground that the editor was probably a pensioner himself.

Maoris are eligible for pensions, as they are both taxpayers and voters. The number of Maoris receiving pensions is one in forty; of the whites, one in seventy. The Maoris are getting proportionately much the largest share of the pensions, and there is to be an investigation. Asiatics are outside the law. The Australasian has no "open door" for the Chinese.

The oldest applicant for old-age pensions in Wanganui was a native woman named Katarina Tiratapu, who alleges she was born one hundred years ago-in I799. Four Maoris applied to the court at Kaiapoi. Two of them could not tell how old they were, but they had been at Kaiapoi before the great tribal war of 1827 - seventy-two years before. The Maoris are large landowners, and when these began to make a statement of their acres they at once disclosed themselves to be too rich to be made pensioners.

At another hearing there was an old Maori veteran who was a strong disciple of $\mathrm{Te}$ Whiti, an adverse claimant as to large tracts of land now held by the whites. This disciple of Te Whiti had, not long before, entered upon this land and ploughed it illegally as an act of defiance. This rebelliousness did not seem to affect his chances, for his case was adjourned only for further inquiries as to his means.

This policy of pensions to the natives is of course severely 


\section{PENSIONS FOR VETERANS OF WORK}

condemned by some. It is pointed out that thirty shillings a month is a small fortune to old natives-a great deal more in proportion to them than to the Europeans. It is also said that little or none of it stays with the recipient, as the younger members of the tribe allow the old natives only the prerogative of collecting the money.

There are no pension lawyers as yet, and the methods of examination adopted by the judges were most considerate. But they did not seem careless. At Auckland, for instance, cne magistrate threw out over a hundred claims.

The judges will accept no testimony as to character from relatives, "for," as one of them said to me, "we would then have the whole family bolstering each other up."

Statements are made by the opposition press of New Zealand that some of the applicants are "well-trained paupers and hardened loafers presenting carefully prepared evidence." Something of this kind no doubt there may be, but the best opinion I could get was that the percentage of fraud which escaped the court is infinetisimal. It is impossible to see the old people in court and in the post-offices collecting their monthly payments, and doubt that they are bitterly in need of the help which they receive.

In going from Kurow to Mount Cook by stage we passed some little "cob huts"-made of mud and straw-squatting close to the river. "Some of our old-age pensioners live there," the driver said. "They are mostly worn-out miners. and would have starved but for that pension. They live in those huts on the public reserves along the river bank. where no one can evict them. They get thirty shillings month and have no rent to pay. They still do a little gold washing and can keep alive, and they know that if they are ever found lrunk they will lose their pension."

There was a great meeting at the opera house in Christchurch during my visit to give the thanks of the old-age 
pensioners of Canterbury to the Premier. An address was presented expressing their gratitude and trusting that he might be spared to enjoy the glory of a ripe old age, and to reap the reward of witnessing the happy effects of the measure upon the aged people of New Zealand, and that New Zealand might be further blessed under his direction with other beneficial social reforms.

In his reply the Premier claimed for New Zealand recognition from the civilised world as the first state to do its duty to its pioneer settlers. He repeated the arguments which he had given to me in conversation that the old-age pensions would not destroy, but, on the contrary, would promote thrift.

"There is," he said to me, "now something for the aged worker to hope for. He or she can say, "If I keep on till I am sixty-five I shall have an old-age pension.' So they struggle along, and sobriety and virtue are encouraged. Under our previous system there was no hope, and weak workingmen or workingwomen took to drink, theft and vice. The others worried on, but in despair, with no energy, breaking down."

To the same effect the Honourable William Pember Reeves has said:

"The New Zealand pension is more likely to induce the poorest to lay by a few pounds to supplement the state's allowance by, say, the purchase of a little annuity, or continue to earn some small wage for the same purpose, than it is to incite them to waste their last shilling because, forsooth, when they come to sixty-five they are to be recipients of a shilling a day."

The Premier in his speech argued that the pension was not a form of charitable aid. It came from the consolidated revenue, to which every pensioner had contributed for twenty-five years. Like education, it was another re- 
turn for their indirect taxation. He pointed out that judges and other civil servants of the state received pensions, and urged that the old workingmen and workingwomen should no more be called paupers when pensioned than the superannuated civil servants. But the Honourable W. H. Montgomery, of the New Zealand Parliament, one of the supporters of the law, calls it "a glorified system of charitable aid." Still, viewed with all its implications and consequences, the old-age pension is something more than a charitable relief. It is given as a right. It is a step toward an equalisation of property. It does not require that its recipients should be paupers. It will inevitably drive the public to support every public and private means of raising the standard of life, so that the workingmen shall not need pensions.

The latest return by the government on the results of the old-age pension law is dated June 19, 1899 . The law came into force November I, 1898. The total number of pensions granted up to March 3I, I899, was 7487, representing a yearly payment of $\mathfrak{E I}_{128,082}(\$ 640,4 \mathrm{IO})$. The average pension is about $f_{1} 72 s$. $(\$ 85.50)$.

A later memorandum, furnished me by the courtesy of Registrar Mason of the pension office, tabulates the results to June 30 :

\section{“Old-Age Pensions Act, I898."}

Statement of claims as on June 30, 1899 .

Number of claims established.............. 9505

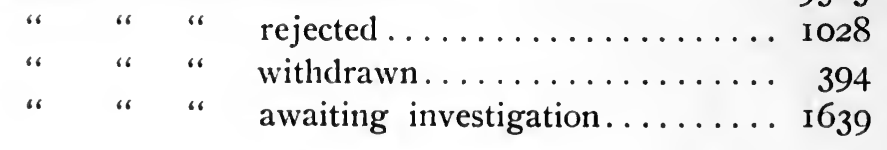


Number of claims established.............. 9505

“

deaths .................... I 57

" cancellations.............. $32 \quad 189$

“ “ pensions in force as on June 30, $1899 \quad 9316$

At the average of $\mathfrak{E}_{\mathrm{I}} 72 s$. the amount payable was, June 30, I899, at the rate of $\$ 796,5$ I8 a year. By April, I900, the pensions had increased to $\$ 950,000$ a year.

The highest amount which has been given to any one by Denmark in its old-age pensions is $\mathfrak{E}_{1} 6 \mathrm{I} 6 \mathrm{~s}$. a year. The Denmark law makes no such statutory limit as the New Zealand law does. It stipulates only that the amount of the pension shall be sufficient to support the pensioner and his family and enough for their treatment in case of sickness. An English Parliamentary document, entitled "Provision for Old Age by Government Action in Certain European Countries," gives the returns for Denmark-the only other country which has old-age pensions-down to 1896 , the latest date for which they are obtainable. The number of persons in receipt of relief has increased from 30,957 in I893 to 36,246 in $I 896$, and the cost of the relief from $£_{164}, 616$ to $\mathfrak{f}_{216,317}$. The sum expended by Denmark on old-age relief has exceeded the total of the appropriations, but the excess was met out of the general fund.

The calculations of the New Zealand government were that the first year's disbursements would amount to $E_{90,000}$ or $\$ 450,000$. The number of pensioners is certain to increase and the disbursements to grow larger, but Mr. Seddon looks forward to this, as he told me, without apprehension.

"If," he said, "old-age pensions increase, so will the wealth and resources of the country, and the burden will be no greater in proportion." 


\section{PENSIONS FOR VETERANS OF WORK}

As to the means by which the funds will be provided for the growing pension list, he said, "If hereafter the burden exceeds our resources, we will tax land and income more, and I have already so intimated."

Mr. Seddon asked Parliament, in 1899 , to extend the privileges of the old-age pension law to foreigners who, through ignorance or misunderstanding, have omitted to naturalise themselves.

$\mathrm{He}$ also promised to consider the demand of one of the women's organisations that women should be eligible for old-age pensions five years earlier than men. A radical wit insists that the decreasing birth rate of New Zealand suggests that the country needs a young-age pension.

The New Zealand law is imitated in a bill which was introduced, late in 1899 , into the Victorian Parliament by the Premier, Sir George Turner. The only important difference between the proposed law of Victoria and the New Zealand law is in a provision that pensions shall be paid to persons before they have reached the age of sixty-five if they have been rendered infirm by unhealthy occupations. The New Zealand press considers this a distinct advance upon the New Zealand system.

The old-age pension is strong with all classes of the New Zealand people, Conservatives as well as the others, for the pity of it; it is strong with the Liberals for the democratic equalisation of property in it; strong with the poor for its freedom from the taint of the "dole."

There can be no doubt that it has captured the heart of New Zealand. It is the most popular of all the advanced legislation of the last ten years. Even those who oppose "on principle" everything done by "the Seddon administration" had words of praise for this. It appeals to a tenderness of heart which is a characteristic of the New Zealand people. One sees this constantly exhibited in their treat- 
ment of women, children, and the helpless. Perhaps this is due to the prosperity of the country. The warm sunshine of good times has quickened their sensibilities. It is not that they have more sensibility than others, but they can better give it play. There is nowhere a kinder people, kind to the unfortunate and the stranger; and the popularity of this helping hand to the forlorn aged is a part of this chivalry.

The Secretary for Labour, in his annual report for 1899 , comments upon the absence of aged tramps looking for work as one of the specially satisfactory features of the year, and he considers this undoubtedly due largely to the operation of the old-age pensions act.

All the world is talking about having some better way of taking care of social wreckage than the poorhouse and the soup-kitchen. The key to the action of New Zealand is the same here as in so many of her novelties. The things others only talk about New Zealand does. 


\section{CHAPTER XV}

\section{“A SUBSTITUTE FOR A FRENCH REVOLUTION"}

THE democratic novelties of New Zealand, excepting its government railroads, life insurance and the Public Trustee, date back only a few years, and are the fruits of the election of I89o. This uprising of the people was called an election, but it was in truth a revolution-just such a revolution as it is the intent of democracy an election shall be when revolution is needed.

We think of New Zealand as a new country, but the fact is that by 1890 New Zealand was one of the oldest of modern societies in economic iniquity and sin, and in some things the oldest. Though the youngest of nations, it had an ancien regimc. Instead of escaping from the evils of the social order by going to a new country, the Englishmen who settled New Zealand found that they had brought all its problems with them, as if these were their shadows, as they were. These evils were not in England but in the English-in themselves as citizens of the world of wealth instead of commonwealth. The concentration of land, capital and other machinery by the few, which has taken half a dozen centuries in Europe, where the "fittest" had to begin with the help only of water-wheels and spears, and has required a hundred years in the United States, needed only a decade or two under the southern sun of New Zealand, where those who were to survive-"convey the wise it call" - had in hand the machinery of steam, credit and politics- 
railroads, banks, government bonds, joint-stock companies and representative government representing the representatives.

By 1890 a situation had developed in the New Zealand paradise which was intolerable, to those at least who har to live in it-the New Zealand people. Its evolution in land had reached an extremer point than it has found either in the United States or England, or even Ireland. The best acres were in the hands of monopolists, who were also absentees, and not only absentees but absentee corporations.

One of the most distinguished citizens of Australasia, a man known in the counsels of the empire as well as in the colonies, said to me, "The land and other legislation of New Zealand and the other colonies is due to the extreme behaviour of the large landowners of the early days. They were almost all men who began without land. They were 'new men,' and had none of the traditions and patriarchal and baronial pride which softens ancestral land-ownership in the old countries. To these men land was simply a means of making money. When they sheared they let the shearers sleep in the open and fed them on the roughest and coarsest fare. They made no sort of concession to the people in any direction. Their policy was, 'Keep off my grass.'"

There was a money ring, too, manipulating the greatest necessity of modern life next to land and transportation-credit. Through the banks it took toll of the business men and of industry and investment. Through the loan agencies and mortgage companies it kept the screw of usury twisting the necks of the farmers, small tradesmen and workingmen.

This land monopoly and money monopoly to defend and aggrandise themselves-monopoly anywhere must be monopoly everywhere-took possession of the greatest mo- 
nopoly of all-government. It was a government of squatters, by squatters, for squatters. "Squatter" is New Zealandese for land monopolist. "Land spotters, speculators and grabbers made laws to suit themselves," says Minister McKenzie. The little farmer, forced by unjust and deliberately contrived laws to pay his own and his rich neighbour's taxes, had to. sell out his little homestead to that neighbour for what he could get. The workingman, able to get neither land nor work, had to become a tramp. The tradesman had to follow his customers, these farmers and workingmen. The blood of the people was the vintage of the rich. There was a "bitter cry of outcast New Zealand." The roads were marched by sturdy men crowding in from the country to the cities. There were problems of strikes, unemployed in town and country, overcrowding, dear money, idle factories, stagnant markets, and unjust taxation.

Premier Seddon has described the condition to which the country had been brought: "We had soup-kitchens, sheltersheds, empty houses, men out of work, women and children wanting bread. This was how we found New Zealand in 1890. It was to be a country where the few were to be wealthy and the many were to be degraded and povertystricken."

Another distinguished New Zealander, Mr. W. L. Rees, the biographer of Sir George Grey, said in Parliament, "Unless there is some amelioration of the terrible suffering which this ceaseless competition is inflicting upon the community we are on the brink of ruin and civil war."

In a country where everything above the foundations was still to be built, skilled mechanics could get no work; where millions of acres of the best land on earth lay idle year after year, farmers, though they had money, could get no land. There was the incredible spectacle of an exodus of men and women with wealth and youth and health leaving this 
rich and virgin country to find in other lands the opportunity denied them there.

That the turning point should have come upon the defeat of what is always referred to in Australasia as "the great strike of I890" was certainly not to have been expected in countries so little industrial as Australia and New Zealand were then. But the unexpected is to be expected, even in those model commonwealths. Discontent had so saturated the people that it needed only an initiative, and the workingmen, because organised, could give this initiative most easily. This strike was originally an affair between the steamship companies and their officers. The seamen magnanimously went in to help out the officers, and with still more magnanimity all organised labour in Australasia sympathetically made the strike universal. The classes and masses in their modern representatives, capital and labour, looked civil war into each other's faces. The strike ended in the complete triumph of the capitalists, because the most united, the best organised, and with the clearest conception of just how much the crisis meant.

All through Australasia this defeat of labour stirred the popular feeling, in an unaccountable way, to the depths. As often seen in history after great calamities, like panic, famine, or conquest, a religious revival followed this catastrophe, especially in New Zealand, but it took the form of a revival of that kind of religion we call democracy. A tidal wave of political reformation rolled over New Zealand and Australia. In New Zealand it swept the Conservative party from power, never to return, and inaugurated the changes in the social economy of the country which it has been the province of this book to chronicle.

The issue has proved it to be a revolution, but it was not a French revolution. It was, one of its leaders said, "a substitute for a French revolution." But it was a revo- 
lution. It was not merely a change in parties; it was a change in principles and institutions that amounted to nothing less than a social right-about-face. It was a New Zealand revolution, one which without destruction passed at once to the tasks of construction.

Merely as an exhibition of a nation's intellectual force, a manifestation of social energy and a display of the wit of the common people, the work done by the New Zealanders in the ten years that followed the overthrow of the old régime is unique.

The intolerable situation of the New Zealanders was much like the intolerable situation in which Europe and America find themselves to-day, except that in one or two respects their evolution, as in land, had reached an impasse more complete than ours. They were not "scientific" students; they were not "reformers"; they were not Utopians, not Altrurians-only citizens of that sober-coloured continent we might call "Actualia." They were hard-working men and women, without leisure or a leisure class. They were not able, like the Greeks, to spend their days in the marketplace talking politics while slaves worked the farms and the mines. They were uninspired men, with no traditions and no theories. They knew nothing about revolution, and had never had to fight for their liberty. They had to make their own living. Their country, in comparison with others, was a toy country, a bijou democracy. I have sometimes thought in New Zealand that the consciousness that their theatre was so small stirs these fellow Anglo-Saxons of ours to play the largest possible parts. Athens and Jerusalem were not big places. The New Zealanders had no philosophy of society, and only a resolve to have the fruits of their own labours and of their own government. They had the help of no eminent statesmen, at least not of any eminent before they made their record here. 
They were just "the common people." But they were truly the common people in a sense in which it has not existed since early New England and which in Anglo-Saxondom exists now nowhere except in New Zealand-the only country wholly English in which practically every settler can read and vote and where the separation of classes has not made common action for the common good impossible.

This common people were stung to action by their sheltersheds, soup-kitchens, relief works, bankrupt traders, tramp workingmen, evicted settlers and the exodus. They set to work to save themselves from this old-world civilisation. In ten years they have produced a budget of reforms, corrective and constructive, and of political novelties which will bear comparison with the work of any other revolution, political or violent, of modern times.

We are exhorted to take "one step at a time," and are assured that this is the evolutionary method. This theory does not fit the New Zealand evolution, as will be seen if we focus in a condensed statement a catalogue of its almost simultaneous reforms.

The creative activity of this democracy-antipodean in more than one sense to that of older peoples-entered nearly every province in the field of modern industrial statesmanship-land, labour and capital, finance, transportation, population, poverty and wealth, domestic and international competition, and the like. It dealt with the tramp, strikes, lock-outs, slums, monopolies, sweating, panics, foreclosures, tax sales, speculation, usury, evictions, rack-renting, disfranchisement, millionairism and pauperism. It went beyond remedies for what was wrong, and invented a new alliance between the state and the producers, to unite the resources of the whole people with those of the individual in a partnership of industry both at home and in the foreign market. 


\section{INSTEAD OF A FRENCH REVOLUTION}

Here is the record of ten years:

The policy of taxation is reversed. The general property tax on improvements, enterprise and poverty is abolished, and the taxation for national purposes of land and incomes introduced. Taxation is taken off from capital that is working and put on capital that is idle. The small man, because small, is exempted, and the rich man, because rich, is made to pay more, progressively, the more land and income he has. The burden of the old property tax forced the poor men who worked their places to sell out to the rich neighbour, who escaped taxation and grew rich by making no improvements. The new tax is planned especially to make the rich landowner sell to his small neighbours or to the government, which will subdivide and sell to them itself. The old taxes built up monopolies; the new taxes "burst them up." To check speculation, to equalise poverty and wealth, to prevent great estates-these are some of its avowed objects. "No man now dreams," an eminent New Zealander said, "of attempting to found a great landed estate in New Zealand."

The people, by the use of their powers as citizens, get land for themselves through the state by taking it back from the men to whom they have previously sold it, and who have addled field after field into great monopolies. The people resume these lands by taxation, by purchase, if the owners are willing to sell, and by force of law if they will not sell. They divide the lands thus recovered into gardens, farms and homesteads for the landless. But to break the vicious circle by which private property in land leads to speculation, rack-rents, foreclosure, depopulation and monopoly the revolution institutes a new system of land tenure. It establishes the lease in perpetuity by the state with limitations of area, cultivation and transfer. It inaugurates a policy which is meant, ultimately, to make the state in New Zea- 
land the owner of all the soil of New Zealand and the people all tenants of the one landlord who will never speculate, nor confiscate nor rack-rent, and whose monopoly is their monopoly.

In their public works policy the people establish themselves as their own contractors. The democracy begins the reform of the sweating system where all reform should begin, at home, by abolishing it in its own work, doing away with the contractor and the contract system, with all its evils of subletting and of sweating the workmen and the work. It enters upon the practice of direct construction by the state of its own public works and direct employment, without middlemen, of its own labour. The men hired by the new régime to build railroads, bridges, public buildings, make roads, etc., are taken by preference from those citizens who need work. In giving them work the new régime also gives them farms and homes from the public lands near by or from the private estates which it buys and cuts up for that purpose. The workingmen themselves are made their own contractors and taught, even the tramp and the casual, to work together co-operatively. The state as an employer sees and saves for the community the economic value of the labour of the old and incompetent, the unskilled and the tramp, which the private employer lets go to waste.

By compulsory arbitration the public gets for the guidance of public opinion all the facts as to disputes between labour and capital, puts an end to strikes and lock-outs, clears its markets and its civilisation of the scandals and losses of street fights between the buyers and sellers of labour, and enables both sides to make contracts without strike clauses for years ahead. It transfers the private wars of economic enemies to a court room, as society had previously taken the private wars of the barons from the field into the 


\section{INSTEAD OF A FRENCH REVOLUTION}

court room. By abolishing the contractor it abolishes the sweating system in public works, and it banishes the sweater in private industry by compulsory arbitration, with its power to fix minimum and maximum wages and all conditions of labour, by forbidding the employment of boys and girls without pay, by the enactment of an advanced and minute code of factory laws, by regulating the hours of women and children and so of men. It establishes a compulsory halfholiday by law for factories and shops. It forbids the employment of uneducated and physically defective children and of all half-timers. For the unemployed the nation. makes itself a labour bureau. It brings them and the employers together. It reorganises its public works and land system so as to give land to the landless and work to the workless. The fraud of compulsory insurance of workingmen by their employer is stopped, and the state itself insures the working people against accident. For those for whom no private employment is to be had the state provides a "state farm"- - a shelter, a waiting-room and a school of work and co-operation. It carries idle men and their families to idle land and organises them in groups of co-operative workers, giving them shelter and providing them with every necessary tool. For the extirpation of the slums-products of speculation in land and of sweating of labour-there are the land laws and tax laws to stop speculation and the labour laws to stop sweating, and, besides, the people have empowered themselves to take land from private owners within or without city limits for suburban homes for themselves by friendly purchase or by condemnation. Instead of paying heavy profits to middlemen the people can divide the lands among themselves at cost, as they have done with the "resumed" farms.

The management of the railroads is changed from boards of commissioners, independent of the people, to a Minister 


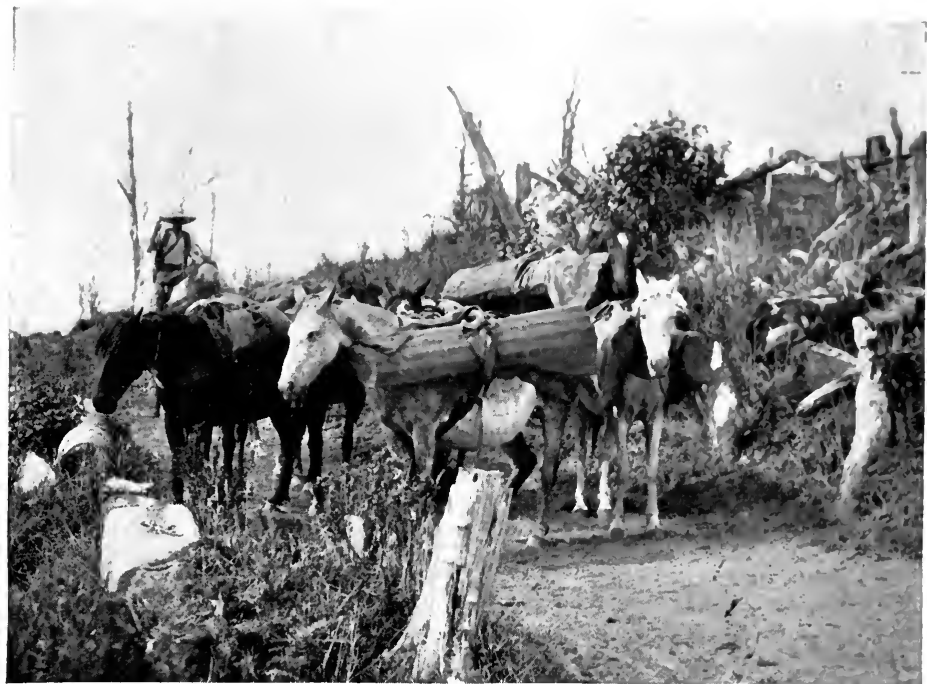

Tin for Houses on the Road to Independence.

(Page 2!1.)

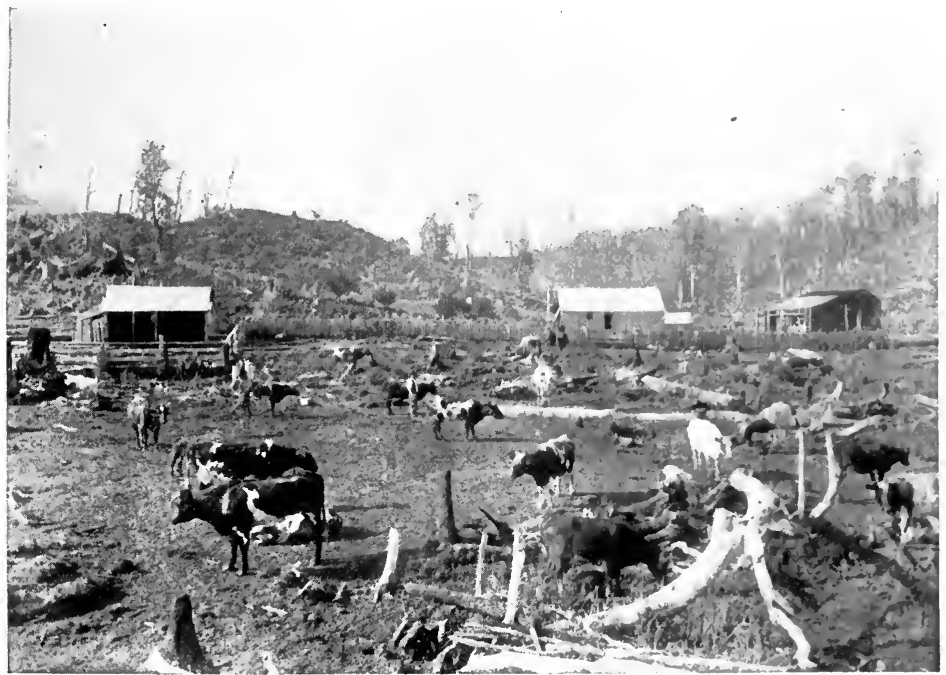

Land for the Landless, Work for the Workless.

(Page 372.) 

and Parliament dependent upon the people and responsive to public needs and public opinion. The railroad policy is changed from the use of the highways as money-makers for the treasury, relieving the general taxpayer at the expense of the producer, to their use as public utilities supplying that necessity of life-transportation-at cost. The new policy is to lower rates, never to raise them, and to keep lowering them as profits increase. New lines are built for the people, not for the great landowners. The methods of construction are changed from private contract to co-operative work, largely by groups of unemployed, with special reference to the settlement of them and other landless people on the land.

The state takes over the management of the principal bank of the colony. It assumes the rôle of chief purveyor of credits to the commercial and financial interests, and so doing saves New Zealand from the panic of 1893 .

The revolution of 1890 does more than follow the line of least resistance-it adopts the policy of most assistance. The commonwealth makes itself the partner of the industry of the people. The nation's railroads are used to redistribute unemployed labour, to rebuild industry shattered by calamity, to stimulate production by special rates to and from farms and factories, to give health and education to the school and factory population and the people generally by cheap excursions. To pay for the lands taken back from the private owners, the people get cheap money on government bonds in London, and to equalise themselves with competitors nearer the world's markets and to emancipate themselves from the usurer, the producers of New Zealand give themselves cheap money through the Advances to Settlers Act. Money is borrowed in London at Treasury rates, to be loaned to the individual in New Zealand at cost, so that a single citizen of New Zealand gets his money 


\section{INSTEAD OF A FRENCH REVOLUTION}

in London at the same rate as if he were the governmentas in truth he is-plus only the small cost of the operation. Instructors are sent about to teach the people co-operation in work and in industry, like dairying, and money is adranced to assist in the erection of creameries. Bonuses are given for the development of new processes. Patents are bought up, to be opened to the people at cost. Millions are spent on water-races and roads to foster mining. The government gives free cold storage at the seacoast and preparation for shipment for products to be exported. The firm of "Government \& Co., Unlimited," is established-a partnership of the people as a state with the people as individuals, in agriculture, gold mining, and manufactures for home and abroad.

Women are enfranchised, and legislation for "one man, one vote," enfranchises men, too, and puts an end to the abuses of plural voting in Parliamentary and municipal elections. On election day one can see the baby-carriage standing in front of the polls while the father and mother go in and vote-against each other if they choose.

Last of all, pensions are given to the aged poor.

And this Fraternalism pays. In reducing railroad rates to the people as profits increase the government increases its profits faster than it reduces rates. The country is prosperous in every department-revenue, manufactures, commerce, agriculture. The democracy is a good business man. The state proves itself a successful money-lender and landlord. It makes a profit and can lower its rents and rates of interest, and, unlike the private capitalist, does so.

Perhaps this is "socialism." Whatever we call it, it is a fact and a success. With the help of policemen and polite society we are keeping socialism out of our streets and parlours, but we do not seem to be able to keep it out of our governments. 
This middle class development of New Zealand does not take the form of the state socialism which demands "the ownership and operation of all the means of production, distribution and exchange." Rather we see the state giving its principal efforts to the stimulation, as a silent partner, wise counsellor and democratic co-operator, of the enterprise and industry of the individual. While theorists invite the world to choose between the catastrophes of state socialism and trust socialism, New Zealand finds a way out between these extremes.

It was "one step," but that step was nothing less than a complete reversal of policy.

Has New Zealand shot its last bolt? Is its armory empty and its energy spent? No, if we can trust the recent complete victory of the progressive party in the election of 1899 , the temper of the people as shown in conversation and the outspoken utterances of their statesmen. Here are some of the definite measures which have been publicly favoured by leaders now active in New Zealand affairs:

State fire insurance.

Further democratisation of transportation by the zone system of rates.

Nationalisation of the steamship lines.

Nationalisation of the coal mines.

Complete nationalisation of the land.

Assumption by the government of the business of mining and selling coal.

Increase of the land and income taxes for the further equalisation of rich and poor.

Removal of tariff taxation on the necessaries of life.

Establishment of government offices where "cheap law" can be served out to the people.

Regulation of rents for the protection of tenants from political pressure by landlords. 


\section{INSTEAD OF A FRENCH REVOLUTION}

Extension of the purchase and subdivision of the large estates so that all the people may have land.

State banking to give the people the ownership and administration of the machinery of commercial and financial credit, doing for the business class what the state with its advances to settlers does for the farmers, tradesmen and workingmen.

The nationalisation of the news service.

The New Zealand idea is the opposite of that of some theoretical creators of society, that the rich are to become richer and the poor poorer, until the whole population has been sifted into brutes of money and brutes of misery, who will then fight out the social question to the death. New Zealand leads in the actual movement now going on in the other direction-the aggrandisement of the middle class. The middle class is not to be exterminated, but is to absorb all the other classes. The world-wide abolition of slavery, the gradual disappearance of absolute political power, the displacement of the individual captains of industry by corporations with multitudes of stockholders, are all illustrations of this tendency. The key to all the legislative and social institutions of New Zealand is in this conscious and unconscious middle class absorption of the extremes. The New Zealander wants no Armageddon of plutocrats and paupers.

One hears little sectarian socialism talked, but is everywhere made aware that the people of all parties are moving steadily toward this fixed purpose : they mean to mould their institutions of taxation, land tenure, public ownership, etc., so that there shall never develop among them those "social pests," the millionaire and the pauper.

The New Zealand policy is a deliberate exploitation of both capitalists and proletariat by the middle class which means to be itself "the fittest that survives." The capitalists 
are taxed progressively, and the proletarian is given land and labour that he may also become a capitalist to be taxed.

There is nothing really new or sensational about the New Zealand democracy. Its political novelties prove upon inspection not to be novelties at all, but merely like most American and Australian slang, old English in a new place. The word of the day has been reform, not radicalism; resistance, not reconstruction. The New Zealanders are not in any sense extraordinary. There is only one remarkable thing about them, and that is an accident. They are the most compact and homogenous, the most equal and manageable democracy in the world. This is luck-not intention but circumstance. The country was too far away from Europe and from the thousand-year-old stream of westward migration to become New Europe, as the United States has done. It became only Newest England-what the Puritans and Pilgrims planned; the kind of country those Englishmen, Washington, Jefferson and Adams, expected would carry on their constitution.

"Let us pauperise you now and we will let you democratise us by-and-by," the monopolists are saying to the people of the world. To become reformers we are all to become proletarians, who have never reformed anybody, not even themselves. Starving men may fight for a bone, but never for liberty. The New Zealanders think that the best way to become free is to remain free.

In New Zealand the best stock of civilisation-ours-was isolated by destiny for the culture of reform, as the bacteriologist isolates his culture of germs. New Zealand has discovered the anti-toxin of revolution, the cure of monopoly by monopoly. New Zealand, because united, was able to lead; because she has led, others can follow. 
○ 


\section{APPENDIX}

\section{STATISTICS OF THE TEN YEARS}

IN his introduction to "A Country Without Strikes" the Honourable William Pember Reeves, ex-Minister of Labour of New Zealand, and author of its Compulsory Arbitration Law, gave some statistics to show that the industries of the country, falsifying predictions, had prospered during the operation of that bold experiment. The following figures, taken from a recent compilation of the Registrar-General of New Zealand, present the details of progress during the decade I890-1899, when the land, labour, fiscal, and other reforms described in this volume were set in motion.

The population of the colony has increased from 626,658 to 756,506 , exclusive of Maoris. Deposits in banks of issue increased 17.97 per cent., from $f_{12}, 368,610$ to $\mathfrak{f}_{14,591,223}$, an increase of $\mathfrak{E 2}_{2,222,613}$; deposits in Post-Office Savings

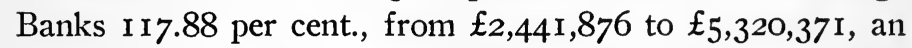
increase of $\mathfrak{E}_{2}, 878,495$; unimproved value of land, I I.79 per cent., from $£ 75,497,379$ to $£ 84,401,244$, an increase of

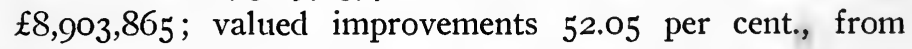
$\mathfrak{E}_{3} 6,640,335$ to $\mathfrak{f}_{54}, 190, I_{0}$, an increase of $\mathfrak{E}_{17} 7,549,768$; the private wealth 52.05 per cent., from $£_{142,631,461}$ to $£_{21}$ 7,-

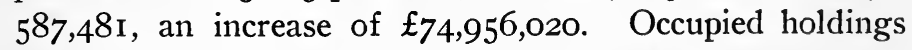
increased from 38,178 to 62,485 , and the customs from

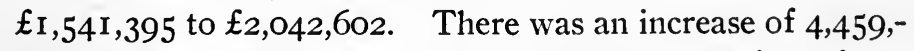
085 acres in the area of cultivated land, exclusive of orchards, gardens and plantations. Sheep increased from 
I6, I I6, I I 3 to 19,348,506; cattle, 5 I3,83I to I,210,439; horses, 2 I I,040 to 260,93 I.

Railways increased in mileage $\mathbf{1 4 . 2 2}$ per cent., and in gross receipts 44.77 per cent. ; the gold output was doubled from $\mathfrak{f}_{733,438}$ in 1890 to $\mathfrak{E}_{1,5} \mathrm{I}_{3}$, I 80 in 1899 . In percentage the population increased by 20.72 per cent. in the ten years; the imports, 45.28 ; the exports, 25.15 ; the customs revenue, 32.48 ; the cultivated land, 55.63 ; sheep, 20.06 ; cattle, 45.52 ; horses, 24. I I t telegraphs mileage, 36.50 ; and messages, in number, 76.92 .

The figures of the increase of the public debt, and its purposes, have been given on page 338 . 
INDEX 



\section{INDEX}

Adelaide, 175

Advances to Settlers, 82, 167, 299, 329, 373; for creameries, 208, 374. See also Government \& Co., Unlimited Arbitration, see Labour

Area, 3

Artisans on the land, 161, 173

Ballance, John, 83, 102, 105, 111,120 121, 130, 134, 150, 155, 173, 195, 196, 204

Bank of New Zealand, 276 et seq., 373

Best, R. W., 167, 247, 269

Bonuses, 310 et seq., 374

Browning quoted, 326

Butler, Minister, 324

Cadman, A. J., 62, 66, 69

Canada, State aid to industry, 330

Capitalists forced to reduce interest, 307; warned, 106

Capital and legislation, 285; no* warred against, 137

Cheap money, 300 et seq.

Cheviot estate, 157 et seq.

Chinese manufacturers in Victoria, 239

City and country, 244

Civil Service Board, New South Wales, 44

Coal ring, 10, 104, 336

Cockburn, John A., 323, $33^{\circ}$

Coghlan, T. A., 44, IOI

Common people, 369

Competition, international, 309; by state, 52

Compulsion, 253, 260

Compulsory arbitration, 18,258 et seq., 372; holidays, see Labour; purchase of land, 127, 143, 144, 145, 172, 1 74, I 76, 230, 370, 373, 375

Conciliation, see Labour

Contractor, abolition of, 82, 103, 371

Contracts and safety of the people, III

Co-operation, $1,87,225,227,374$; in Canada, 331; in land settlement, 83 , 178,209 ; in New Zealand, 332, 374; in public works, $83,160,209,371$; at state farm, 202; for unemployed, 217,220 et seq. ; in Victoria, 321

Co-operative butty gangs, 100; coal mine, 87; contracts, $82,103,371$; criticisms, IOr; sugar mills of Queensland, 309 et seq.

Cowles, James L., 79

Credit as necessity of life, 287

Danton, I1, 326

Davitt, Michael, 220, 313

Debts, public, 4, 56, 150, 281, 338

Democracy, I, 4, 7, 59, 61, 85, 87, 141, 164, 198, 212, 260, 276, 289, 297, 303, $325,364,367,369,374,377$

Denmark, old age pensions, 339,346

Diaz, 85

Education, 45, 212, 230, 246, 372 ; and politics, 296; technical and agricultural, 230

Eight hours' movement, 233, 234

Eli, H. G., 123

Exodus, 84, 108, 134, 366

Factory Acts, see Labour Laws

Families of workingmen kept together, 200

Farmers' support of labour policy, 242

Fraud prevented by arbitration, 267

Germany, pensions, 34I

George, Henry, 120

Gladstone, W. E., I5I

Government printing office, 90

Grace, M. S., 292

Grey, Sir George, 81, 121, 126, 129

Hall-Jones, Wm., 102

Horticultural school, 320

Human nature, 331

Immigration, 4, 13, 57, 67, 192, 377

Improved Farm Settlements, see Land 
Insurance, accident, 257,372 ; fire, 375 ;

life, 12 et seq., 181

International arbitration, 275

Interest rates reduced, 307

Irrigation, 320

Isolation, 3, 377

Japanese labour, 315

Jennings, W. T., 217

Kea, 6

Kenney, H. Eyre, 346

Kidd, Benjamin, 314

Kingston, C. C., 86, 224, 307, 322, 327

Labour, accident insurance, 257; arbitration, South Australia, 237, 264; bureaus, 197, 198, 200; children, 254; Chinese evasion of minimum wage law, in Victoria, 239; compulsory arbitration, 18,258 et seq., 372 ; compulsory half-holiday, 246,252 , $253,254,372$; conciliation, 261 et seq.; and contract system, 83 et seq.; see also contractor and co-operative contracts; Department, 200, 202,246 et seq., 372 ; domestic service, 257; employment of boys and girls without payment, prevention act 256,372 ; factory inspection, 255, 256; hours, 47, 49, 233, 234, 252, 254, 255, 372 ; Japanese, 315; labour law penalties, 255 et seq.; labouring men in Ministry, 196, 243; laws, 223 et seq., 372 ; leaders' evolution, 243; Leongatha state farm, 230 ; mental, 251 ; minimum wage law of Victoria, 236; minimum wage in New Zealand, 256, 372 ; mothers, 254 ; old workmen, $89,95,203,238$, $241,248,343,37$. See also Old Age Pensions; organisations, 233; parties, 155, 233, 234, 242, 313; program supported by farmers, 242; seats for shop-girls, 254; shop regulation, 254, 255; state farm at Levin, 202, 372. Sce Trades-Unions; wages, $47,89,97$. See Minimum Wage Law; white against black, 310 et seq. ; workman defined, 175 . See Unemployed

1.and, advances for improvements, 174 ; Ardgowan, 172; artisans as settlers, 161, 173; auction, I41 ; ballots, 139 , I41, 189; Board, 182; bonanza farming, 172 ; Cheviot estate, 157 et seq., complaints, 163, 180; closer settlement, 82, 94, 157 et seq., 172, 179; closer settlement productiveness, 166 ; compulsory purchase, 127 , $143,144,145,172,174,176,230,370$, 373,375 ; consolidation, $127,152,154$, 162; co-operative villages, 178 ; Department and unemployed, 200 et seq., 250; distribution, 152; dummyism, 128; effect of land tax, 170, I 71 ; Elderslie estate, I 70 ; examinations of applicants, 182; Fair Rent bill, 179; freehold, 135, 153 , 154, 156, 196, 370; Gladstone, W. E., 151 ; grant to railroads, 53,54 ; gridironing, 127, 133; homestead blocks in South Australia, 175; homesteads reserved, $146,157,181$; Improved Farm Settlements, 99, 204 et seq.; irrigation, 320; large es. tates, 68, 107, I16, 122, 1 33, 156, 170 , 370,376 ; laws, 137 et seq. ; leasehold conditions, 184; leasehold in perpetuity, 139, 140,142, 147, 153, $167,178,370$; Maoris, 29, 178 ; married men favoured, 213; McKenzie on new Irish land policy, 136; Momona, 162; monopoly, 4, 104, 126, 132, 134, 136, 149, 365; mortgages, 133; Murray River colonies, 221 ; nationalisation, 154 ; native, 29; New South Wales, 155; Oklahoma, 19I ; owned by absentee corporations, 128, 365 ; petitions for land resumption, 168; prices, 164 , 177; private ownership, 155; purchase, rule of compensation, 145 ; Queensland, 155; and railways, 68; ranger, 185 ; rents, 179 ; rents, regulation of, 375 ; resumption, 127,143 , $150,155,156,172,174,176,180,230$, 370 ; revaluation, 179; Rolleston, Wm., 154, 193; scrutineer, 189; settlements profitable, 180, 219 ; setsettlement and public works, 83; settlement and railways, 67 ; small ownership and large ownership compared, 166, 171, 172; speculation, $143,148,155,156,162,370$; spotting, 127, 133; suburban homes, I74, 372 ; taxation, 104 et seq. ; tenantry 133, 15 I, 154, 173; values increased by state aid to production and export, 62, 329; Victorian Minister of Lands on Cheviot, 167 ; village set. tlements, 92, 94, 170, $172,173,174$, $175,178,180,193,195,196,204$; Waikokahi estate, Iso; Whangamo- 
mona, 208; white men under Maori landlords, 30; women as settlers, I 85 ; workmen's settlements, I 73, 174 Langley, Venerable Archdeacon, 102

Law of the market, 304

Lawyers, government, 30 ; in Compulsory Arbitration Court, 263

Levin state farm, 201

Life insurance, 12 et seq., 181

Makohine viaduct, 82,96

Maoris, 1, 6, 9, 29, 56, 105, I 78, 205

Martin, John C., 21

March, J. E., I98

Massachusetts Board of Arbitration, 260

McGregor, Dr. Duncan, 340

McKenzie, John, 129, I30, 132, I33, $135,136,138,139,143,144,146,147$, $148,149,150,1_{54}, 1_{55}, 1_{57}, 1_{58}, 196$, 203, 206, 366

McLachlan, Minister, 334

Melbourne Trades Hall, 233

Mexico, 85

Middle class, 376

Millionaires not wanted, 4, 376

Mills, James, 269

Miners subsidised, $310,333,334,374$

Momona, 162

Money for farmers, 299 ; market law, 304 ; ring, 299, 365

Monopoly, curse of, 104. See Land. See Rings.

Montgomery, W. H., 360

Nationalisation, banking, 376 ; c0al, 337,375 ; fire insurance, 375 ; land, 154, 375; lawyers, 375 ; mines, 236 ; news, 375 ; steamships, $50,337,375$

New South Wales, Advances to Settlers, 299; before and after the panic, 297 ; Board for Exports, 321 ; butty gangs, 100; Civil Service Board, 44 ; co-operative colonies for unemployed, 226; co-operative villages, 92; eight hours' day in public works, 234; government does not recognise trades-unions, 236; Labour Party, I55, 234; land, 155; miners subsidised, 334 ; panic of 1893,277 ; railways, $32,35,37,41$, $44,48,50,51,53,54,58$; State aid to industry, 310 et seq. : sugar, 316; unemployed, 198, 199, 250 ; Unem. ployed Advisory Board, I02, 203, 228 et seq.; wells for farmers, 310

New York and panic of 1837,280
Oamaru, 52

Old Age Pensions, 2, 9, 112, 339 et seq.

Oliver, Railroad Commissioner, 36

Paine, Thomas, 346

Panic of 1893,276 et seq., 373

Parliamentary government and possibilities, 295

Pauperism in England, 108

People, 14, 74, 326, 369, 374

Plunkett, Horace, 227

Population, 3, 4, 10

Postal Savings Bank, 55, 18 I

Post Office, 55, 299, 339

Pott, G. W., 316

Printers' farm, 218

Progressive Liberals, 122, 341

Public Trustee, 12 et seq., 181

Public Works, 67, 69 et seq., 82, 107, $160,200,250,292,371$

Queensland, aid to production and export, 3 Io et seq. ; co-operative sugar mills, 309 et seq.; land, 155 ; railways, 32, 36, 37, 4I, 42, 48, 50, $5 \mathrm{I}$, 53, 54, 58; subsidies to miners, 334

Railways, 3I-81 ; Appeal Board, 45, 46, 49; appointments, $39,42,43$; arbitration, 45,47 ; average haul, 50 , $5 \mathrm{I}$; breeding animals, 33 ; coal rates, 51; Commissioner system, 46, 47, 70 ; comparison of rates, $5 \mathrm{I}$; construction, 69, 372 ; Cowles, James L., 79 ; criticisms, 63,64 ; deficit, 49 , 50 ; discrimination, 35,36 ; earnings, 49, 50; educational qualification, 45; employés, 39,42 et seq. ; employés and politics, 38,48 ; experts, 43; favouritism, 35 ; forfeiture, 53,54 ; fruit, 33 ; genius, 43 ; holidays, 49; hours of labour, 47, 49; Hungary, 77, 8I; land grants, 53,54 ; and land values 13,68 ; libraries, 33 ; lime, 33,82 ; management by Minister, $71,372,373$, the Midland, 53; new lines, 39-41, 372; New South Wales, 32, 35-37, 41, 44, $48,51,53,54,58$; newspapers, 33 ; parcels, 33; pensions, 49; policy, $31,50,56,61,62,67,72,373,374$; political pressure, 38,70 ; power of public in management, 60 et seq., 75 ; private, 51,53 , 54 ; promotion, 43,44 ; public and private compared, $51,54,56,59,66,67$; Queensland, $32,36,37,41,48,50,51,53,54,5^{8}$; 
rates, $3^{2}$ et seq., $39,51,53,61,65$, 71 ; rates, gazetted, 42 ; rates high, 51,73 ; rates to large and small shippers, 35 ; rates never raised, 66,373 ; rates reduced for farmers, $6 \mathbf{1}, 62,65$; rebates, 35 ; reduction of rates, 62 , 65; Russia, 35, 77, 81; and school children, 31, 69, 373; second class accommodation, 64 ; seeds, 34 ; settlement, 67, 372; South Australia, 32, $36,39,48,50,58$; "starved-sheep rates," 69; stock, 33; suburban trains, 33; Sydney tram-car men, 48, 49; Tasmania, 5o; trades-unions, $47,48,73$; and unemployed, 67,372 , 373 ; vacancies, 43 ; Vaile, Samuel, 72,75 ; vegetables, 33 ; Victoria, 36 , $40,43,49,50,58,72$; vote, 38,48 ; wages, 47; water competition, 52 ; Wellington and Manawata, 51; Western Australia, 50; and working people, 32, 33, 50,69, 73, 373; workshops, 57,58 ; zone system, 72, et seq., 375

Rees, W. L., 366

Reeves, Wm. P., 106, 107, I17, 126, $136,247,259,274,359$

Religion and democracy, 367

Rents, regulation of, $33^{8}$

Rings, coal, ro, 104, 337; government, 366 ; land, 104, 365; meat-freezing, Io; money, I04, 299, 365 ; sheep, 10; shipping, 87, 104, 335; timber, 10

Rolleston, Wm., 154, 193, 204

Russia, railways, $35,77,81$

Salisbury, Marquis of, 254

Savings banks, 55

Schools and government, 296, 297

Seddon, R. J., 31, 62, 68, 74, 80, 84. 95 , 102, 105, 106, I $12, I_{1}, 124,153,155$, 1 73, 206, 254, 269, 273, 289, 308, $336,337,338,345,359,361,366$

Seligman, Professor, II

Settlements, see Land

Shipping ring, 87, 104, 335

Shop Acts, see I,abour Laws

Skertchly, Professor, 314

Socialism, 375 ; Australasian, 335

South Australia, advances to settlers, 299,329 ; arbitration, 237,264 ; contracts for steamship freights, 328 ; co-operative villages, 92 ; homestead blocks, 175; income tax, 118; land, I55; land tax, I21; produce export depot, 310, 322 et seq. ; railways, 32, $36,39,48,50,5^{8}$; state bank, 294,
300,305 ; telephones, 55,56 ; village settlements, 220, 226, 227

Spahr, Charles B., 172

Speculation in land, 155, 156, 162, 370

State, Bank, 293 et seq., 300; as banker 278 et seq., 376; bull, 326; coal dealer, 337; clothing factory, ror; as competitor, 52 ; in co-operative sugar mills, 309; employer, 371; exporter, 309 et seq.; farm, 20I, 372 ; as farmer, 159 ; fire insurance, 375 ; help, I ; hotelkeeper and guide, 34 ; as insurer, 12, 181, 257; as landlord, 151, 154, 173, 374; as landmonopolist, 371 ; lawyers, 30, 375; as money broker, 299, 374 ; as monopolist, 377; news distribution, 375 ; partner, 369, 375; railways, 3I-8I ; railway workshops, 57,58 ; real estate dealer, I4I, I 5 I; savings banks, 55 ; socialism, 375 ; steamships, 50 , 327; sugar refiner, 316; telegraphs, 55; telephones, 55

"Stone wall," 345

Stout, Sir Robert, 127, 130, I45, 155

Street car lines, New South Wales, 48

Strike of 1890, 10, 46, 233, 259, 367

Strikes still possible under compulsory arbitration, 271

Suffrage, 340, 374

Sugar Mills, New South Wales, 313; Queensland, 309 et seq.

Taverner, Minister, 333

Taxation, absentees, I12, 117, 118; Cheviot Estate, I1 5 ; Cheviot valuation, 158; corporations, 112, 118 ; death duties, I16; Ell, Henry George, I23; Henry George, 120; illustrative figures, 115 ; improvements exempt, I12, 114 ; improvements taxed, I09; income tax, 105, $112,117,118,119$; land and income tax, I05, I I I, I I 2, I I 8, I 21 , I 58, I 70, I 71, 370, 375; land tax and large estates, 116, 119; life insurance premiums exempt, 118 ; mortgages, 112 , $113,114,116$; for old and infirm taxpayers, 113; Pitt, 124; progressive, 105, I1 2, I 16, I18, I81, 370; property tax, I09, 370; rating of unim. proved values, 120; Seligman, Prof., I 4 ; single tax, 120; small men, 112, $113,116,118,370$; South Australia, 121; steamship companies, II8; tariff, 122, 375; valuations, I15 ; yield of absentee $\operatorname{tax}, 117$; yield of 
graduated tax, 117; yield of income tax, 119; yield of land tax, 117, 119

Telegraphs, 55

Telephones, 55

Trades-Unions, 10, 47, 48, 73, 74, 87, $233,236,264,271$

Tregear, E., 197, 199, 247

Trenwith, W. A., 167

Tropical labour problems, 314

Trustee, Public, 12 et seq., 181

Trust socialism, 375

Tucker, 209

Unemployed, 67, 69, 82, 92, 94, 102 , 160, 192, 197 et seq., 203, 228 et seq., $245,366,372,373$

Union Steamship Co., 46

Vaile, Samuel, 72, 75

Victoria, advances to settlers, 299 ; aid to export and production, 310; before and after the panic of 1893,297 ; benefits of policy of bonuses, 322 ; Chinese manufacturers, 239; con- tracts for steamship freights, 317 , 333; co-operative contracts, 100 ; co-operative education, 321 ; horticultural school, 320 ; irrigation, 320 ; labour organisations, 233; Leongatha State Farm, 230; minimum wage law, 236; Minister of Lands on Cheviot, 167; Old-Age Pension Bill, 362 ; railways, $36,37,40,43,49$, 50,58 , 72; sugar mill, 316 ; telephones, 55

Village settlements, see Land Vogel, Sir Julius, 13, 58, 67, 130, 192

Wakefield, Edward Gibbon, 8

Wallace, Alfred Russel, I, 314

Ward, J. G., 66, 342, 344, 347

West Australia, 50, 155, 329, 334

Wheat yield, 164,181

Wingless birds, 7,117

Women, 185, 202, 238, 252, 254, 314, $320,340,362,374$

Workman defined, 175

Workingmen and Ministry, 196, 243 



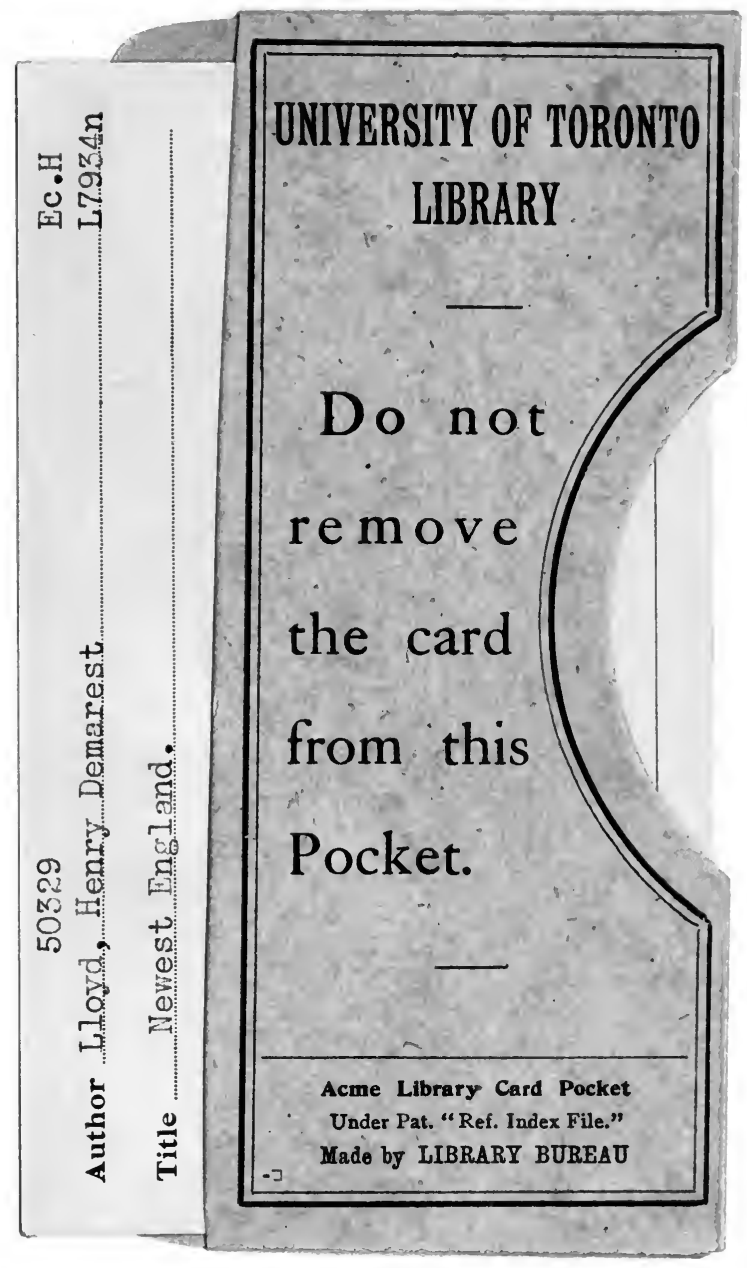




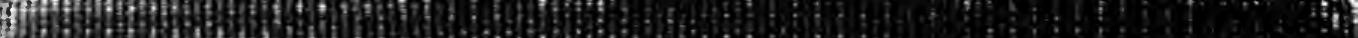

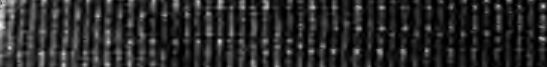

fff

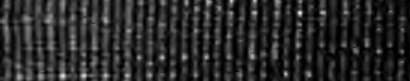

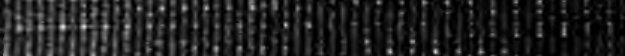

H:f,

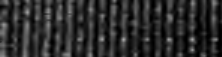

iffif:

Affy:

1)

H)

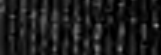

19.

(1):

dis:

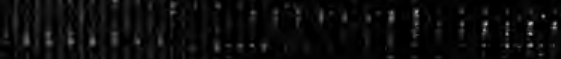

$(x)$

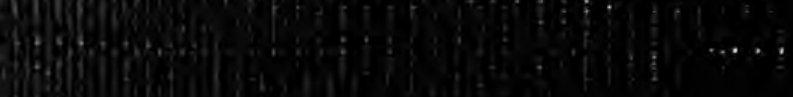

If(j)

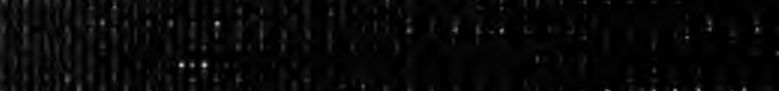

(1)

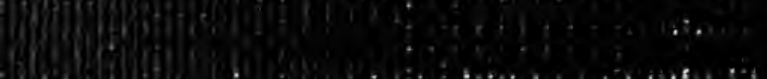

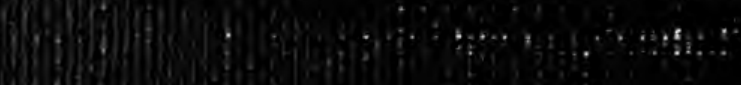

IX)

(1)

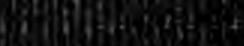

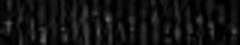

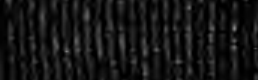

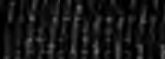

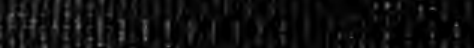

th.

(3)

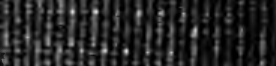

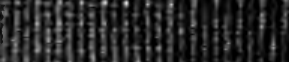

If: If

(f)

H.

fitis:

7

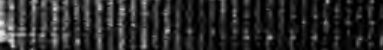

